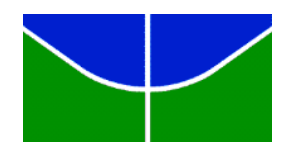

\author{
UNIVERSIDADE DE BRASÍLIA - UNB \\ CENTRO DE EXCELÊNCIA EM TURISMO - CET \\ Programa de Pós Graduação em Turismo \\ Mestrado Profissional em Turismo
}

TURISMO RESPONSÁVEL: UMA ANÁLISE DA RESPONSABILIDADE NA GESTÃO PÚBLICA BRASILEIRA

CAROLINA FÁVERO DE SOUZA

Brasília - DF

2014 


\section{CAROLINA FÁVERO DE SOUZA}

\section{TURISMO RESPONSÁVEL: UMA ANÁLISE DA RESPONSABILIDADE NA GESTÃO PÚBLICA BRASILEIRA}

Dissertação apresentada ao programa de Mestrado Profissional em Turismo da Universidade de Brasília na linha de pesquisa de Desenvolvimento, Políticas Públicas e Gestão no Turismo, como requisito parcial para obtenção do título de mestre.

Orientadora: Prof. ․․ Dr $\stackrel{a}{a}$. Donária Coelho Duarte 


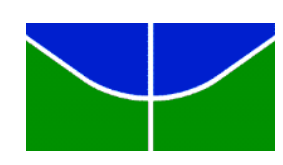

\author{
UNIVERSIDADE DE BRASÍLIA - UNB \\ CENTRO DE EXCELÊNCIA EM TURISMO - CET \\ Programa de Pós Graduação em Turismo \\ Mestrado Profissional em Turismo
}

\title{
TURISMO RESPONSÁVEL: UMA ANÁLISE DA RESPONSABILIDADE NA GESTÃO PÚBLICA BRASILEIRA
}

\author{
Banca Examinadora: \\ Prof. ${ }^{\text {a }}$ Dra Donária Coelho Duarte - UnB \\ (Orientadora)
}

Prof. Dr. Leandro Martins Fontoura - UFRRJ

Prof. ‥ Dra . Maria Elenita Menezes Nascimento - CET/UnB

Brasília - DF

2014 


\section{$\psi$ \\ UNIVERSIDADE DE BRASÍLIA - UNB \\ CENTRO DE EXCELÊNCIA EM TURISMO - CET \\ Programa de Pós Graduação em Turismo \\ Mestrado Profissional em Turismo}

Dissertação de autoria de Carolina Fávero de Souza, intitulada Turismo Responsável: uma análise da responsabilidade na gestão pública brasileira, submetida ao Centro de Excelência em Turismo da Universidade de Brasília, como parte dos requisitos necessários para a obtenção do grau de Mestre em Turismo, em 08/10/2014, defendida e aprovada pela banca examinadora abaixo assinada:

Prof. ‥ Dra ${ }^{\text {a }}$ Donária Coelho Duarte - CET/UnB

(Orientadora)

Prof. Dr. Leandro Martins Fontoura - UFRRJ

Prof. ${ }^{\text {a }}$ Dra Maria Elenita Menezes Nascimento - CET/UnB 


\section{FICHA CATALOGRÁFICA}

Souza, Carolina Fávero de.

Turismo Responsável: uma análise da responsabilidade na gestão pública brasileira / Carolina Fávero de Souza, 2014.

219 р.:

Dissertação de Mestrado - Universidade de Brasília, Centro de Excelência em

Turismo, 2014.

Orientadora: Donária Coelho Duarte.

É concedido à Universidade de Brasília permissão para produzir cópias desta dissertação, emprestar ou vender tais cópias somente para propósitos acadêmicos e científicos. O autor reserva outros direitos de publicação e nenhuma parte dessa dissertação pode ser reproduzida sem autorização por escrito do autor.

Carolina Fávero de Souza 
Qos meus pequeninos amores, Goaquim e Goão Miguel, por me preencherem e encherem minha vida de amor e de alegria.

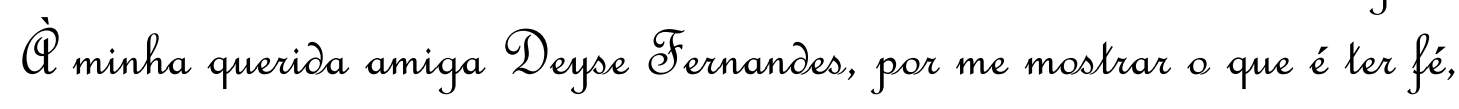
perseverança e gratidão pela vida. $Q$ todos que tomam a responsabilidade para si como um fundamento de suas atitudes e acreditam na sua essencialidade para a construção de um mundo melhor, de liberdade e de valorização do ser humano e da natureza. 
A elaboração de uma dissertação de mestrado é predominantemente um ato solitário, porém nela interferem muitas pessoas, as quais contribuíram de inúmeras maneiras para a sua consecução. Portanto, expresso aqui meus profundos agradecimentos a elas.

Esse é um trabalho no campo do turismo e do lazer, entretanto, paradoxalmente para concretizá-lo tive que me abstrair disso durante grande tempo, assim como tive que restringir a minha convivência com os meus familiares e com os meus amigos, privandoos de momentos de partilha durante demasiado tempo. Um agradecimento emocionado a todos eles pela compreensão, pelo incentivo, pela torcida e pelo apoio imensurável. Em especial, aos meus pais, Neuza Fávero e Mário Fernandes, ao meu irmão, Gustavo Fávero, à minha cunhada, Juliana Braga, às minhas amigas Cecília Parente, Deyse Fernandes, Kátia Debret, Karine Mendes, Camila Bizerra, Thaís Brito, Mariana Berbert e Heloísa Machado. Sem vocês não teria sido possível!

À Professora Dra Donária Coelho Duarte, primeiramente por ter aceitado a orientação desse trabalho nas condições desafiadoras que se apresentavam, e, principalmente, por ter proporcionado uma orientação de excelência, franca e cúmplice, o que permitiu um salto quântico no desenvolvimento dessa pesquisa. Agradeço, ainda, sua paciência, sua dedicação e sua amizade.

Aos amigos Humberto Fois e Carla Fraga pelo auxílio essencial ao início dessa empreitada. Às parceiras Ana Paula Cappellano e Thamyris Andrade pela amizade incondicional e pela ajuda imprescindível, tanto prática quanto emocional, durante 0 desenvolvimento dessa pesquisa. Não tenho palavras para agradecê-las! À Laura Fabri pela grande amizade e pela colaboração com as traduções. À Mariana Neves pela luz e energia a mim doadas. À Valéria Martim por sua dedicação em me auxiliar e por me ajudar a focar e persistir. Ao Zé Carlos pelo companheirismo, carinho e auxílio essenciais para a conclusão da versão definitiva dessa dissertação.

Aos colegas e aos amigos do CET e do CDS pelos momentos de descoberta, de enriquecimento intelectual e de partilha de dificuldades. Em especial às amigas Elissélia Ramos, Geruza Erig, Juzânia Brandão, Ângela Gomes, Laís Martins, Leiliane Rebouças e Carla Oliveira.

A todos os professores do CET, especialmente a Prof ${ }^{-}{ }^{\text {a }}$ Karina Dias, o Prof. Dr. Neio Campos, a Prof ${ }^{-a}{ }^{-a}$ Marutschka Moesch, a Prof ${ }^{a}{ }^{-a} r^{-}$Cléria Botelho, o Prof. Dr. Luís Spiller, pelos conhecimentos transmitidos, pelo apoio, incentivo, compreensão e ajuda nos momentos mais difíceis dessa enriquecedora experiência.

Ao Prof. Dr. Gilson Borda por ter me apresentado ao Turismo Responsável e por ter me impulsionado e incentivado no início desse percurso. À Professora Dra ${ }^{a}$ Helena Costa pelas reflexões provocativas e por todas as contribuições enriquecedoras. Ao Prof. Dr. Harold Goodwin pelo rico material produzido sobre o tema, pela atenção concedida em entrevista e por toda a generosidade no compartilhamento de seu conhecimento.

Ao grande amigo Professor Dr. Leandro Fontoura e à Prof ${ }^{a}$ Drª Maria Elenita Nascimento pelo estímulo e auxílio, pelas observações criteriosas e contribuições valiosas após a leitura dedicada e carinhosa do meu trabalho. 
Aos meus inúmeros colegas e amigos do Ministério do Turismo pelo convívio harmonioso, pelas palavras de incentivo e pelas experiências compartilhadas. De maneira especial, aos amigos Rodrigo Rios, Adriana Serpa, Taís Dias, Bruno César, Samarina Carreira e Wanessa Côrtes, que sempre torceram por mim e me deram uma palavra de apoio e motivação quando precisei. Um profundo agradecimento aos meus chefes - Fernanda Matos, Fabiana Oliveira, Cristiano Borges e Wilken Souto - pela infinita compreensão e apoio durante esse período de dedicação dupla. Um agradecimento particular ao meu chefe e amigo Ítalo Mendes, por ter sempre me incentivado a me dedicar à ampliação da minha vida acadêmica, por acreditar em meu potencial, pela confiança em meu trabalho e por ser um grande entusiasta do turismo.

A todas as pessoas que se disponibilizaram a compartilhar a sua opinião e o seu conhecimento nas entrevistas dessa investigação.

A todos que direta e indiretamente ajudaram de alguma maneira a realização desse trabalho, e que aqui eu não ousaria cometer injustiças ao tentar citar um a um.

Força, fé e foco! 
When 9 tell people that thinking about heisure and tourism is my profession, they often smile. Obsiously, they do not find it serious, they do not see it as work, and only work can be serious. At these moments 9 almost always feel $\mathscr{Y}$ should apologize. Of course, they say, heisure and travel are perhaps two of the nicest things in the world, but really, when you get down to it, they are rather krivial matters.

I beliese they are much than that, for they concern the happiness of the indisidual and the well-being of our society, and these, eseryone would agree, are central issues in our lives.

$$
\text { Gost Krippendorf }
$$


Quando eu digo às pessoas que pensar sobre o lazer e o kwismo é minha profissão, elas costumam rir. Obsiamente, elas acham que isso não é sério, pois não veem isso como trabalho, e somente - krabalho pode ser sério. Thesses momentos, en quase sempre sinto que devo me desculpar. É claro, elas falam, lazer e viagem são taliez duas das melhores coisas do mundo, e é verdade que quando pensamos bem, são questões realmente triviais. Qcredito, conkudo, que são muito mais do que isso, pois o lazer e a viagem relacionam-se com a felicidade do individuo e com o bemestar da sociedade, e isso, todo mundo concordaria, são aspectos centrais em nossas vidas. 


\section{RESUMO}

Investigou-se neste trabalho se as atuais políticas públicas de turismo implantadas pelo Governo Federal Brasileiro contemplam o Turismo Responsável (TR) nos seus diversos campos - ambiental, social, cultural e econômico. Partindo dessa questão central, o objetivo geral deste estudo foi analisar as políticas públicas em curso no Ministério do Turismo (MTur) sob a ótica do Turismo Responsável para identificar iniciativas que possuam o seu pilar na responsabilidade. Trata-se de uma pesquisa aplicada, exploratória e descritiva, com abordagem hipotético-dedutiva, realizada por meio de levantamento bibliográfico e documental, recorrendo-se a fontes tanto nacionais quanto internacionais. Utilizou-se, também, pesquisa de campo, a qual consistiu em entrevistas semiestruturadas com gestores públicos do Ministério do Turismo, que foram estudadas com abordagem qualitativa e por meio da análise de conteúdo para verificar seu conhecimento e sua familiaridade sobre o tema, além de examinar quais as iniciativas foram percebidas por eles como tendo relação com o TR. Obteve-se como resultados que o MTur demonstra incorporar a responsabilidade em sete de suas ações, porém nem sempre todas as dimensões da responsabilidade são abarcadas. E que, apesar dos entrevistados terem apenas uma noção do que seria o TR, o conceito de responsabilidade é conhecido e desejado no âmbito do planejamento e desenvolvimento do turismo. Como recomendação foi proposta, ao final da pesquisa, entre outras coisas, a realização de seminários internos para divulgação e esclarecimentos sobre o tema.

Palavras-chave: Sustentabilidade; Turismo Responsável; Políticas Públicas; Ministério do Turismo. 


\begin{abstract}
This present work investigated if the current public policies on tourism implemented by the Brazilian Federal Government take the Responsible Tourism in its different realms environmental, social, cultural and economic - into account. Starting from this core question, the general aim of this study was to analyze the ongoing public policies in the Ministry of Tourism (MTur) from the perspective of the Responsible Tourism (RT) so as to identify initiatives that are lain on responsibility. It is an applied, exploratory and descriptive research, with deductive hypothetical approach, accomplished through bibliographical and documental survey, tapping national and international sources. The study also employed a field survey, which consisted of semi-structured interviews with public officials of the Ministry of Tourism, examined by means of a qualitative approach and contents analysis, with a view on verifying their knowledge and familiarity on the topic, as well as looking into which initiatives were perceived by them as being related to RT. As a result, it was possible to determine that MTur demonstrates to assume the responsibility in seven of their actions, yet not always all of the dimensions of the responsibility are embraced. Furthermore, although the interviewees have just a notion of what RT would be, the concept of responsibility is known and wanted in the tourism planning and developing scopes. At the end of the study, recommendations were made for, among others, the holding of internal seminars for the dissemination and elucidation of the theme, and the adoption of RT as a guideline or central pillar for the development of all MTur actions.
\end{abstract}

Key Words: Sustainability; Responsible Tourism; Public Policies; Ministry of Tourism. 


\section{LISTA DE FIGURAS}

Figura 01 - Etapas da dissertação $\quad 29$

Figura 02 - As fases do método Hipotético Dedutivo 36

Figura 03 - Tipos de Pesquisa Científica 39

Figura 04 - Três condições da Responsabilidade $\quad 55$

Figura 05 - Condições para ser um agente moral 56

Figura 06 - Características do Turismo Responsável 89

Figura 07 - Períodos da ação do Governo Federal sobre o Turismo 101

Figura 08 - Estrutura do Documento da África do Sul 127

Figura 09 - Objetivos da Responsabilidade Econômica da África do Sul 133

Figura 10 - Objetivos da Responsabilidade Social da África do Sul 136

Figura 11 - Objetivos da Responsabilidade Ambiental da África do Sul 139

Figura 12 - Objetivos do Marketing de Gâmbia 141

Figura 13 - Objetivos e Premissas da Responsabilidade Econômica de Gâmbia 142

Figura 14 - Objetivos e Premissas da Responsabilidade Social de Gâmbia 143

Figura 15 - Objetivos e Premissas da Responsabilidade Ambiental de Gâmbia 145 


\section{LISTA DE QUADROS}

Quadro 01 - Conceitos de Responsabilidade $\quad 60$

Quadro 02 - Passos Essenciais ao Movimento do Turismo Responsável 78

Quadro 03 - Histórico da gestão pública do Turismo no Brasil 121

Quadro 04 - Análise das iniciativas de Turismo Responsável do MTur - 01

Quadro 05 - Análise das iniciativas de Turismo Responsável do MTur - $02 \quad 167$

Quadro 06 - Análise das iniciativas de Turismo Responsável do MTur - $03 \quad 170$

Quadro 07 - Análise das iniciativas de Turismo Responsável do MTur - $04 \quad 171$

Quadro 08 - Análise das iniciativas de Turismo Responsável do MTur - 05

Quadro 09 - Análise das iniciativas de Turismo Responsável do MTur - $06 \quad 177$

Quadro 10 - Análise das iniciativas de Turismo Responsável do MTur - $07 \quad 178$

Quadro 11 - Alcance da responsabilidade pelas iniciativas do MTur 182 


\section{LISTA DE ABREVIATURAS E DE SIGLAS}

AlH - Associação Internacional de Hotelaria

AITO - Associação de Operadores Turísticos Independentes

ASTA - American Society of Travel Agency - Sociedade Americana de Agências de Viagem

BID - Banco Interamericano de Desenvolvimento

CNTur - Conselho Nacional de Turismo

DIP - Departamento de Imprensa e Propaganda

ECPAT - Articulação Internacional contra a Prostituição, Pornografia e Tráfico de Crianças e Adolescentes

EMBRATUR - Empresa Brasileira de Turismo

FIAV - Federação Internacional das Agências de Viagem

FORNATUR - Fórum Nacional de Secretários e Dirigentes Estaduais de Turismo"

Fungetur - Fundo Geral do Turismo

Funtur - Fundação Nacional do Turismo

GIZ - Deutsche Gesellschaft für Internationale Zusammenarbeit - Agência de Cooperação Alemã

IATA - Internacional Air Transport Association - Associação Internacional de Transporte Aéreo

IBAMA - Instituto Brasileiro do Meio-Ambiente e dos Recursos Naturais Renováveis

IBDF - Instituto Brasileiro de Desenvolvimento Florestal

ITF-STD - International Task Force on Sustainable Tourism Development - Força Tarefa Internacional pelo Deseolvolvimento do Turismo Sustentável

IUCN - International Union for Conservation of Nature - União Internacional para a Conservação da Natureza

IUOTO - International Union of Official Travel Organizations - União Internacional de Organizações Oficiais de Viagens

MDA - Ministério do Desenvolvimento Agrário

MDS - Ministério do Desenvolvimento Social e Combate à Fome

MTur - Ministério do Turismo

OMT - Organização Mundial do Turismo

Plantur - Plano Nacional de Turismo

PNMT - Programa Nacional de Municipalização do Turismo 
PNT - Plano Nacional do Turismo

PNUMA - Programa das Nações Unidas para o Meio Ambiente

PROECOTUR - Programa para o Desenvolvimento do Ecoturismo na Amazônia Legal

Prodetur - NE - Programa de Desenvolvimento do Turismo no Nordeste

PRT - Programa de Regionalização do Turismo

SBClass - Sistema Brasileiro de Classificação de Meios de Hospedagem

SISNAMA - Sistema Nacional do Meio Ambiente

SNPDTur - Secretaria Nacional de Programas de Desenvolvimento do Turismo

SNPTur - Secretaria Nacional de Políticas de Turismo

TBC - Turismo de Base Comunitária

TR - Turismo Responsável

TSI - Programa Turismo Sustentável e Infância

UIOOT - União Internacional de Organismos Oficiais de Turismo

UNEP - United Nations Environment Programme - Programa das Nações Unidas para o Meio Ambiente

UNESCO - United NationsEducational, Scientific and Cultural Organization - Organização das Nações Unidas para a Educação, a Ciência e a Cultura

UNWTO - United Nations World Tourism Organization - Organização Mundial do Turismo das Nações Unidas.

VSO - Voluntary Service Overseas

WCU - World Conservation Union - União Mundial de Conservação

WWF - World Wildlife Found - Fundo Mundial da Natureza 


\section{SUMÁRIO}

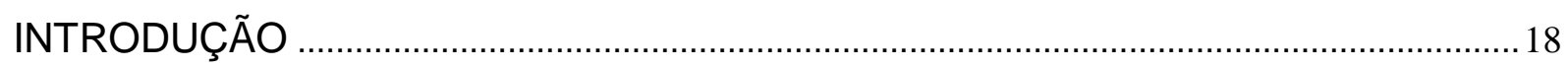

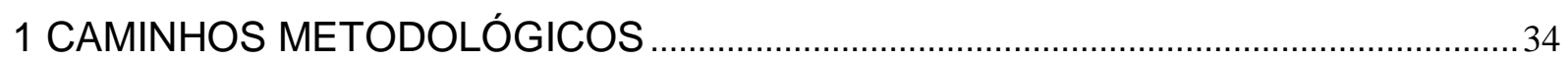

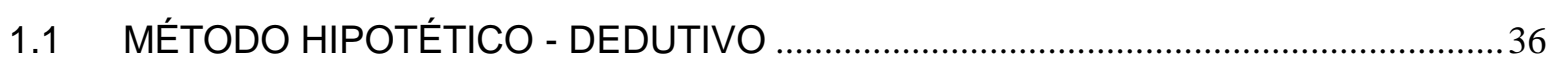

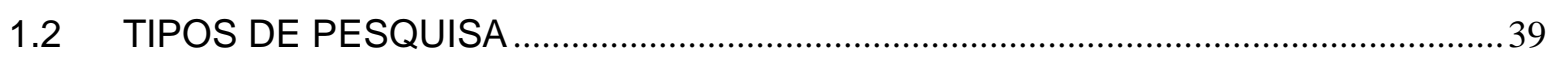

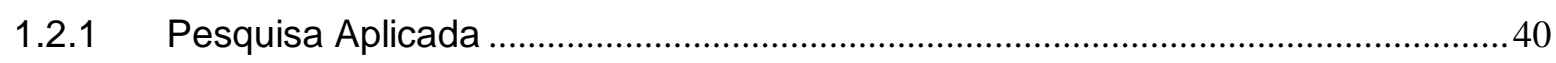

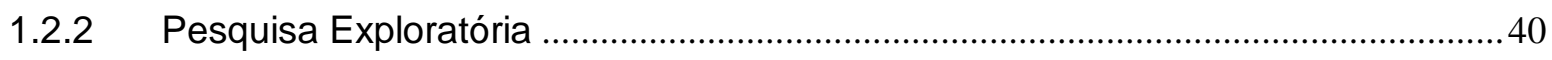

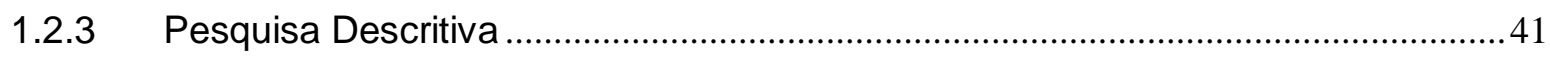

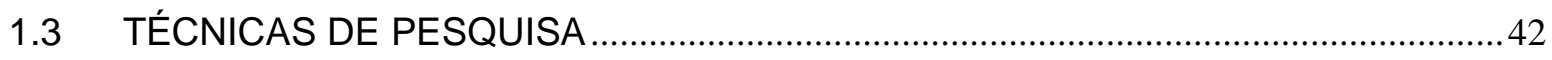

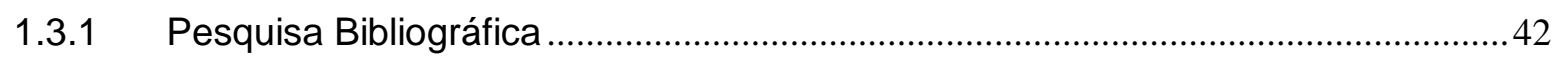

1.3.2 Pesquisa Documental .............................................................................................4

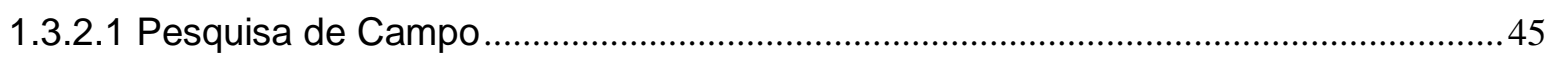

1.3.3 Tratamento dos dados - abordagem ...................................................................48

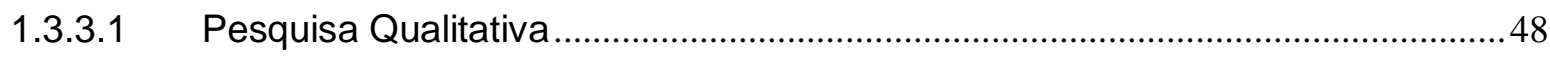

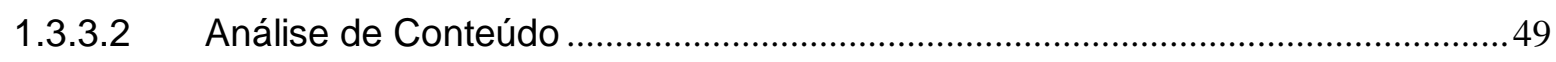

2 DENOTAÇÕES E CONOTAÇÕES DE SER RESPONSÁVEL .......................................51

2.1 RESPONSABILIDADE: ORIGEM E SIGNIFICADOS .............................................52

2.2 A RESPONSABILIDADE NAS ORGANIZAÇÕES ......................................................

3 A APROPRIAÇÃO DA RESPONSABILIDADE PELO TURISMO …………………....70

3.1 O CONTEXTO HISTÓRICO DA EMERGÊNCIA DE OUTRO TURISMO....................71

_3.2 CONCEITUAÇÃO DO TURISMO RESPONSÁVEL ……………………………......

3.3 ORIGEM DO "MOVIMENTO" DO TURISMO RESPONSÁVEL …………………........84

4 AS POLÍTICAS PÚBLICAS DE TURISMO E SUA EVOLUÇÃO NO BRASIL ...........92

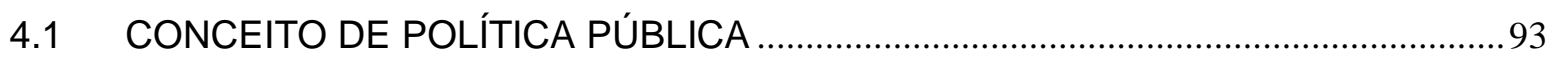

4.2 PAPEL DAS POLÍTICAS PÚBLICAS PARA O DESENVOLVIMENTO DO TURISMO

4.3 HISTÓRICO DA GESTÃO FEDERAL DO TURISMO NO BRASIL ............................99 
5 A EXPERIÊNCIA DE POLÍTICAS PÚBLICAS DE TURISMO RESPONSÁVEL NO MUNDO

5.1 POLITICA PÚBLICA DE TURISMO RESPONSÁVEL NA ÁFRICA DO SUL 125

5.2 POLÍTICA PÚBLICA DE TURISMO RESPONSÁVEL EM GÂMBIA 139

6 APRESENTAÇÃO E ANÁLISE DAS POLÍTICAS PÚBLICAS DO MINISTÉRIO DO TURISMO

6.1 O CONTEXTO ATUAL BRASILEIRO

6.1.2 O Plano Nacional de Turismo 2013 - 2016 147

6.2 AS INICIATIVAS RESPONSÁVEIS DO MINISTÉRIO DO TURISMO

6.2.1 Programa Turismo Sustentável e Infância

6.2.2 Turismo de Base Comunitária

6.2.3 Programa Turismo Acessível 154

6.2.4 Passaporte Verde 157

6.2.5 Viaja Mais - Melhor Idade 159

6.2.6 Programa Talentos do Brasil Rural 161

6.2.7 Programa De Regionalização Do Turismo 163

6.3 ANÁLISE DAS INICIATIVAS RESPONSÁVEIS DO MINISTÉRIO DO TURISMO ....... 163

7 A RESPONSABILIDADE NA VISÃO DOS GESTORES DO MINISTÉRIO DO TURISMO

7.1 PERCEPÇÕES SOBRE TURISMO RESPONSÁVEL PELOS GESTORES PÚBLICOS FEDERAIS DO MINISTÉRIO DO TURISMO 186

CONSIDERAÇÕES FINAIS 197

REFERÊNCIAS 208

APÊNDICE 
You need a change of soul rather than a change of climate. You must lay aside the burdens of the mind; until you do this, no place will satisfy you. 
Nas últimas décadas, particularmente do fim dos anos de 1960 aos primeiros anos de 2000, as agendas sociais e políticas internacionais foram tomadas por uma preocupação coletiva com a manutenção e a preservação dos bens naturais do planeta. Hoje, muito se debate sobre conscientização ecológica e preservação ambiental assuntos outrora negligenciados pelos principais atores da economia e política globais.

É nesse contexto de preocupações com o meio ambiente que surge a noção de sustentabilidade. Devido às suas origens e aos desdobramentos dos seus debates ao longo do século $X X$, esse tópico aparece atualmente, também, ligado às pautas de desenvolvimento econômico e de globalização, e ainda, às de desenvolvimento social.

Segundo Nascimento (2012), a ideia sobre sustentabilidade tem duas origens. A primeira está na biologia, por meio da ecologia, e faz referência à própria "capacidade de recuperação e reprodução dos ecossistemas (resiliência) em face de agressões antrópicas (uso abusivo dos recursos naturais, desflorestamento, fogo etc.) ou naturais (terremoto, tsunami etc.)" (NASCIMENTO, 2012, p.01). E a segunda origem encontra-se na economia, como um adjetivo do desenvolvimento. Isso acontece como consequência da crescente percepção durante o século $X X$ de que o padrão de produção e consumo em expansão global, sobremaneira no último quarto desse século, não possui possibilidade de persistir. A noção de sustentabilidade, portanto, surge sobre a percepção da finitude dos recursos naturais e de sua gradativa e ameaçadora redução.

As discussões que envolviam esse tema tomaram força a partir da década de 70 , quando algumas ações importantes sobre esse assunto foram realizadas, como a publicação do relatório "Limites do Crescimento" (Limits to growth) ${ }^{1}$ e a realização da reunião do Clube de $\mathrm{Roma}^{2}$, fatos estes que demonstravam fatores limitantes ao crescimento e revelavam a inviabilidade da perpetuação do padrão de desenvolvimento vigente. Além disso, houve, ainda nessa década, a realização da Conferência de Estocolmo ${ }^{3}$, a criação do Programa das Nações para o Meio Ambiente (Pnuma), e a publicação do livro "Small is beautiful", ${ }^{4}$ que chamava a atenção para problemas de produção e consumo, ao ressaltar que o modelo de produção dominante era prejudicial ao meio ambiente e ao próprio homem (COSTA, 2013).

\footnotetext{
${ }^{1}$ Coordenado por Dennis Meadows.

${ }^{2} \mathrm{O}$ Clube de Roma era uma ONG composta por cientistas, pesquisadores, funcionários de órgãos governamentais e organismos internacionais de todos os continentes.

3 Em 1972.

${ }^{4}$ Publicado em 1973 por Schumacher.
} 
Essas posteriores discussões ${ }^{5}$ geraram a compreensão de que a sustentabilidade possui também uma dimensão social, visto que a pobreza pode ser provocadora de agressões ambientais e, portanto, a sustentabilidade precisaria abordar a equidade social e a qualidade de vida das gerações atual e futuras. Nascimento (2012) observa que a "solidariedade com as próximas gerações introduz, de forma transversal, a dimensão ética" (NASCIMENTO, 2012, p.01).

Percebe-se que a inserção do tema da sustentabilidade nas preocupações contemporâneas alcança os mais variados setores dessa sociedade, entre os quais está o campo que nos interessa para esse trabalho - o do turismo, sabidamente um dos que pode tornar-se de maior impacto na saúde natural, social e/ou urbana de comunidades locais e no equilíbrio de ecossistemas.

Esse campo é de natureza multidisciplinar e complexa. Não possui um significado consensual e definitivo. O termo "turismo" apresenta uma variedade de definições, as quais abarcam contradições e consensos de diversas origens. Moesch (2002, p.09) explica que o turismo é "uma combinação complexa de inter-relacionamentos entre produção e serviços, em cuja composição integra-se uma prática social (...)". E ainda completa que o somatório de toda a dinâmica sociocultural envolvida nas relações do turismo gera "um fenômeno, recheado de objetividade/subjetividade, consumido por milhões de pessoas, como síntese: o produto turístico" (MOESCH, 2002, p.09).

Devido a sua complexidade, vale destacar que a concepção de turismo aqui adotada envolve a sua pluralidade e a necessidade de uma visão sistêmica sobre ele, já que dessa maneira é possível entender sua complexidade, e, assim, realizar uma melhor análise, ao levar em consideração perspectivas complementares. Como ressalta Costa (2013, p.19), "dentro do mesmo destino existem muitos turismos, traduzidos em seus sistemas e cadeias produtivas, exatamente no plural". Ela ainda afirma que "destinos turísticos comportam-se como sistemas complexos, dinâmicos e evolutivos, acompanhando os inúmeros vetores e as múltiplas atividades que atuam de modo interdependente, sobre eles" (COSTA, 2013, p.22).

\footnotetext{
${ }^{5}$ Nascimento (2012) destaca além dos embates ocorridos na Conferência Global da ONU sobre o Homem e o Meio Ambiente (Estocolmo - Suécia, 1972), as discussões que aconteceram na Conferência Mundial da ONU sobre Meio Ambiente e Desenvolvimento (Eco 92 ou Rio 92 - Rio de Janeiro, Brasil).
} 
É relevante lembrar ainda que de acordo com o ponto de vista de análise sobre o turismo, ele pode ser um fenômeno social, uma atividade econômica, um setor ou uma indústria; fato este que evidencia sua inerente complexidade (COSTA, 2013, p. 20).

A maneira como se desenvolve o turismo - ou até mesmo o modo como ele é visto como "correto" - é dinâmica e relacionada ao paradigma econômico predominante à época (COSTA, 2013). Deste modo, o cenário relativamente recente de preocupação com a preservação do planeta eleva a percepção dos impactos negativos do turismo - os quais abarcam outros campos além do ambiental - e a emergência da necessidade de se repensar o planejamento e o desenvolvimento do turismo, uma vez que esses impactos são intrínsecos ao turismo, porém, na maioria dos casos, eles são exacerbados devido ao fato de que as comunidades recebem mais visitantes do que comportam $^{6}$ e de uma maneira desgovernada, ou seja, sem planejamento.

Como consequência, sobre esses impactos negativos, no campo ambiental, por exemplo, pode-se mencionar o aumento da produção de resíduos, a perda da biodiversidade, o agravamento da poluição e a degradação das paisagens dos destinos turísticos. No sociocultural, citam-se as alterações nos padrões de moralidade mudanças em crenças, valores, comportamentos e costumes - e nas atividades tradicionais; o aculturamento; a invasão de privacidade; o aumento populacional, a ampliação do tráfego de veículos, da prostituição, da exploração sexual infantil e de adolescentes e o acréscimo da criminalidade; e, ainda, o surgimento de conflitos nas comunidades receptoras. No campo econômico, aponta-se como consequências a pressão inflacionária, a especulação imobiliária e o acréscimo no custo de vida da população local, a dependência do turismo pelo município receptor ("monocultura"), a evasão de divisas e os impactos em outros setores econômicos (KOROSSY, 2008; FLETCHER, 2005).

Posto isso, é possível notar que essa outra maneira de se fazer turismo - que leva em consideração a preocupação com os seus impactos negativos - emerge, então, no contexto das grandes discussões internacionais de conservação do planeta, e, além disso, no concomitante cenário de crescimento desenfreado do turismo gerado pela

\footnotetext{
${ }^{6}$ Assunto relacionado com capacidade de carga turística, que conforme Boo (1990) é o número máximo de visitas em um determinado período de tempo (dia, mês ou ano) que uma área pode suportar antes que ocorram alterações no meio físico e social. E de acordo com Pearce (1981, apud JOAQUIM, 1997, p.72), "a capacidade de carga estará ultrapassada quando 'as atividades turísticas estão saturadas - capacidade física -, o ambiente degradado - capacidade ambiental - e a convivência entre residentes e visitantes se torna desagradável - capacidade psicológica individual e colectiva"'.
} 
democratização das viagens - ocasionada por diferentes fatores, tais como: a evolução dos sistemas de transporte e de comunicação, os avanços tecnológicos, a expansão da economia urbana, a redução da jornada de trabalho e a valorização do lazer. Em decorrência disso, advém o avanço na percepção - por parte dos governos, das organizações da cadeia turística e até mesmo das comunidades envolvidas - dos impactos físicos, econômicos e sociais do turismo de massa ${ }^{7}$.

Aliado a esses fatores, acredita-se que o perfil do turista moderno tenha se modificado. Somadas às causas citadas anteriormente, que também influenciam a conscientização desse sujeito, essa mudança de perfil acontece, ainda, em decorrência da ampliação das preocupações pela saúde pessoal; do alargamento da sofisticação do consumo e do aumento generalizado de férias repartidas, além da maior confiança dos consumidores traduzida no desafio de férias mais independentes (KRIPPENDORF, 1989; DAVIDSON, 1992).

Como consequência, tem-se observado que a partir da década de 90 houve uma preocupação crescente em se desenvolver o turismo de uma forma responsável e ética não só para com o meio ambiente, como também para os visitantes e, principalmente, para as comunidades receptoras e para os moradores/habitantes de destinos turísticos. Diante disso, percebe-se que uma forma responsável e ética de se desenvolver o turismo envolve a apreciação da sustentabilidade não só na área ambiental, como também na social, cultural e econômica. A sustentabilidade quando é absorvida pelo turismo gera o que ficou conhecido como Turismo Sustentável. "A noção de turismo sustentável está diretamente ligada aos seus impactos tratados de modo sistêmico, tendo em vista minimizar os danos e maximizar os ganhos sociais, econômicos e ambientais, simultaneamente" (COSTA, 2013, p. 45).

Várias tentativas foram feitas para se definir o conceito de Turismo Sustentável, todavia não se chegou a um consenso em torno de uma única definição (BENI, 2004; BORGES, 2013). Trata-se de um conceito muito amplo e ainda mal definido, utilizado em diferentes contextos e por diversos atores (BUTLER, 1999; FERRETI, 2002 apud BORGES, 2013) e acabou sendo considerado utópico ou um mito por alguns autores. Sua

\footnotetext{
${ }^{7}$ De acordo com Ignarra (2003), "a era das ferrovias representou uma segunda etapa no desenvolvimento do turismo. O rápido crescimento da população e da riqueza criou um enorme mercado em um curto período de tempo. Dada desse período o surgimento das viagens de massa e dos agentes e operadores turísticos, que desenvolvem novas formas de marketing, como as viagens previamente organizadas, pacotes turísticos, cartazes e folhetos" (IGNARRA, p.05, 2003). .
} 
utilidade na busca da sustentabilidade no desenvolvimento do turismo é reconhecida até mesmo pelos que o considera um "sonho impossível" (SWARBROOKE, 1998, apud BORGES, 2013), porém a questão do seu conceito ser considerado muito vago também é colocada em pauta. Em decorrência disso, surge o conceito de Turismo Responsável (TR), o qual possui seu pilar central focado nas relações humanas, e, apesar de também buscar o desenvolvimento sustentável do turismo, foi cunhado para ser um conceito palpável, prático e mais compreensível que o da sustentabilidade, muitas vezes considerado um conceito etéreo (GOODWIN, 2014, informação verbal) ${ }^{8}$. Assim, seu equilíbrio encontra-se na ética dessas relações, as quais envolvem o turismo. Na prática seu comedimento está na relação entre turistas, instituições turísticas (públicas ou privadas) e comunidades locais, e destes com o meio ambiente.

Foi a Conferência de Manila ${ }^{9}$, promovida pela Organização Mundial do Turismo $\mathrm{OMT}^{10}$, em 1980, o marco das primeiras tentativas dessa reinvenção das práticas do turismo, por meio do debate de um conjunto de pressupostos conceituais que se encontram na base da relação entre o turista, as comunidades locais e os agentes de desenvolvimento turístico. $O$ evento procurou promover uma nova concepção do turismo, que iria além dos objetivos econômicos anteriormente entendidos como prioritários. A OMT, ainda, reconheceu o conteúdo das motivações turísticas como sendo majoritariamente cultural e passou a privilegiar o turismo interno em detrimento do turismo internacional indiferenciado. Tem origem, assim, a preocupação com os reflexos do desenvolvimento da atividade turística no que diz respeito também aos aspectos sociais, culturais, ecológicos e ambientais (JOAQUIM, 1997; BRITO, 2009).

A partir de então, observa-se a multiplicação de encontros de caráter científico regionais, nacionais e internacionais - que produzem inúmeros documentos oficiais, como declarações de intenções, códigos de ética e de conduta e, ainda, relatórios referentes à atividade turística. A Declaração de Tamanrasset, promovida pela OMT em 1989, é um exemplo, e defende o turismo alternativo, que respeita o ambiente e as comunidades receptoras. Esse documento inaugura o discurso de oposição ao turismo de massa, em

\footnotetext{
${ }^{8}$ Informação fornecida por Goodwin em entrevista com a pesquisadora em Brasília / Brasil, em 29 de abril de 2014.

${ }^{9}$ Primeira Conferência Internacional da OMT sobre Turismo Mundial. O evento contou com a presença de 107 Estados e 91 observadores. A Declaração de Manila foi adotada depois da Conferência Mundial de Turismo e é a primeira declaração em que se indica que os recursos (espaços, bens e valores) não podem ser empregados de forma descontrolada (COSTA, 2013).

${ }^{10}$ World Tourism Organization - WTO.
} 
um período no qual o turismo internacional continuava a crescer conforme o modelo tradicional de concentração espaço-temporal (JOAQUIM, 1997; BRITO, 2009).

$\mathrm{Na}$ década de 1990, outros importantes documentos vieram somar-se às iniciativas que acabaram por compor uma série de princípios fundamentais que dariam origem, nos anos seguintes, ao conceito de Turismo Responsável - TR. Entre eles se destacam a Agenda - 21 para o Turismo ${ }^{11}$ em 1992, a Carta do Turismo Sustentável de Lanzarote $^{12}$ em 1995 e a Declaração de Berlim ${ }^{13}$ em 1997. Já em 1999, é fundamental ressaltar o lançamento do Código Mundial de Ética no Turismo, que foi adotado pela OMT. Este documento é um dos mais importantes para se chegar ao conceito de Turismo Responsável segundo Goodwin (2014), visto que possui os princípios base deste. Nesse Código são explicitados dez princípios para a prática do turismo, com o foco no respeito às diferentes sociedades e culturas. O Código considera que "todos os tipos de desenvolvimento turístico que economizam os recursos naturais e evitam a produção de dejetos devem ser privilegiados". (COSTA, 2013, p. 43).

É nesse cenário que começam a surgir e a se firmarem termos e segmentos do turismo ligados a essa preocupação, como os termos "turismo alternativo", "turismo ético", "turismo endógeno" e os segmentos "ecoturismo", "turismo ecológico" e "turismo de natureza". Contudo, foi só em 2002 que um relevante passo foi dado a favor do tema: a I Conferência Internacional sobre Turismo Responsável, realizada na Cidade do Cabo, África do Sul. Ela reuniu 280 delegações, de 20 países, com o objetivo de discutir como essa visão de turismo poderia ser definida e colocada em prática. O evento resultou na criação da Cape Town Declaration on Responsible Tourism ${ }^{14}$, documento cujo conteúdo serve de base para o "movimento", pois aponta as principais características do Turismo Responsável e suas diretrizes (GOODWIN, 2005).

\footnotetext{
${ }^{11}$ Segundo Costa (2013, p.42), ela nasce a partir da Eco 92 (ou Conferência das Nações Unidas sobre o Meio Ambiente, RJ, Brasil). O debate resulta na construção do conceito de turismo sustentável como prática que se preocupa com a manutenção da integridade cultural e do meio ambiente. Enumera as áreas prioritárias de ação para o setor de turismo, envolvendo empresas e governo, em termos de sustentabilidade.

${ }_{12}$ Organizada a partir da Conferência Mundial de Turismo Sustentável, indica um plano de ação para o turismo sustentável. Pioneira no entendimento sobre sustentabilidade nos três aspectos - ecologicamente suportável, economicamente equitativo e sob uma perspectiva ética e social para as comunidades locais. (COSTA, 2013).

${ }_{3}$ Surge no âmbito da Conferência Internacional de Ministros de Meio Ambiente sobre Biodiversidade e Turismo. Indica a necessidade de monitoramento das atividades turísticas, de inventário das atividades e atrativos, de restrição para a prática turística em determinados locais e restrição ao uso inadequado de bens naturais para a produção de lembranças turísticas. (COSTA, 2013).

${ }^{14}$ Declaração da Cidade do Cabo sobre Turismo Responsável, 2002.
} 
Cabe ressaltar que a África do Sul foi o primeiro país a adotar explicitamente uma estratégia de Turismo Responsável, ao desafiar os stakeholders a assumirem suas responsabilidades no desenvolvimento do Turismo. Seu governo identificou o Turismo Responsável como peça-chave para o desenvolvimento do turismo no país e entendeu que o princípio da responsabilidade nesse setor "implica uma atitude proativa da parte dos parceiros da 'indústria' do turismo para que a desenvolvam, operem e gerenciem de uma maneira responsável, a fim de criar uma vantagem competitiva" (GOODWIN, 2012, p.7).

A trajetória desse país rumo ao Turismo Responsável começou em 1996 quando o governo sul-africano lançou o "White Paper on the Development and Promotion of Tourism in South Africa", documento que apontava como cada ator do turismo deveria contribuir para o desenvolvimento responsável dessa atividade (GOODWIN, 2012). Ainda no mesmo ano, o Departamento de Assuntos Ambientais e Turismo da África do Sul formulou os "Princípios para o Turismo Responsável", que informavam sobre o desenvolvimento de uma agenda para a Conferência ${ }^{15}$ e para a Declaração ${ }^{16}$. O empoderamento de "comunidades previamente negligenciadas" e das mulheres nessas comunidades era fundamental para o Governo sul-africano, princípio que fez com que o conceito de empoderamento fosse incluído na definição de Turismo Reponsável (GOODWIN, 2012, p.7).

Após a publicação do "White Paper", a África do Sul continuou trilhando o caminho para o desenvolvimento do Turismo Responsável e hoje pode ser considerada referência na criação de documentos na área. Além da "Cape Town Declaration" e do "White Paper" outras importantes contribuições para o incremento dos princípios do TR foram desenvolvidas por este país: ainda em 2002, a formulação das "South African National Responsible Tourism Guidelines"; em 2003, a publicação do "Responsible Tourism Manual and Handbook" e, em 2009, o estabelecimento dos "National Minimum Standards for Responsible Tourism". Dessa forma, pode-se afirmar que a política de Turismo Responsável da África do Sul, especialmente da Cidade do Cabo, fornece um arcabouço de informações, de documentos e de exemplos positivos que podem servir de fundamentação teórica e de base de apoio para a administração desse setor em outras

\footnotetext{
${ }^{15}$ Conferência Internacional para o Turismo Responsável em Destinos, que aconteceu em 2002 na Cidade do Cabo na África do Sul.

${ }^{16}$ Declaração da Cidade do Cabo, 2002.
} 
regiões do mundo, principalmente em países com características semelhantes, e, consequentemente, para o desenvolvimento do Turismo Responsável.

Ao perceber esse cenário, sucintamente já explanado, da emergência de um "outro" 17 Turismo - baseado na reinvenção dessa prática de forma alternativa com foco no ser humano, no respeito, na ética e na responsabilidade - e ao notar que, opostamente às atitudes tomadas pela África do Sul em sua gestão pública federal do Turismo descritas acima, no Brasil nunca houve um Plano Nacional de Turismo Responsável ou um documento que forneça, de forma explícita, diretrizes nacionais para o planejamento e o desenvolvimento do TR; a pesquisadora foi motivada a fazer uma análise sobre a relação da responsabilidade com a gestão pública federal do turismo no Brasil.

Não houve aqui a intenção de se avaliar se a adoção explícita da nomenclatura "Turismo Responsável" seria a mais adequada para o desenvolvimento do turismo no Brasil, ou se essa atitude traria ou não mais consequências positivas ao turismo brasileiro em detrimento da adoção da terminologia "Turismo Sustentável". Mas sim, a preocupação em se analisar se a gestão federal brasileira do turismo tem se preocupado com a fomentação da responsabilidade no desenvolvimento do turismo no país.

Lembrando que, sempre que se fala em responsabilidade no turismo durante esse trabalho, menciona-se a relação com os princípios advindos do conceito de Turismo Responsável, que serão estudados e analisados no decorrer desse estudo.

Para a realização dessa pesquisa, recorreu-se ao método de análise "HipotéticoDedutivo", o qual se baseou na seguinte hipótese de pesquisa: Sendo o Ministério do Turismo o órgão responsável pela gestão pública federal do turismo no Brasil e se o Turismo Responsável é um pilar fundamental da gestão contemporânea do turismo no mundo, então o MTur está incorporando o Turismo Responsável no delineamento de sua gestão.

Dessa maneira, a análise sobre Turismo Responsável no Brasil desenvolvida por esse estudo possuiu como indagações propulsoras os seguintes questionamentos: a) Apesar de não existir um Plano Nacional de Turismo Responsável no Brasil, as políticas públicas federais do País contemplam a fomentação e o desenvolvimento responsável do turismo? b) Caso positivo, como isso é feito? c) $O$ atual Plano Nacional de Turismo

\footnotetext{
17 "Outro turismo": termo utilizado por Moesch e Gastal (2004) em livro que discute a possibilidade de existir um turismo que leve em consideração a sustentabilidade, tanto cultural quanto ambiental, e que tenha bases éticas e busque atender às necessidades mais profundas dos viajantes, sem discriminar cidadãos, com o envolvimento de gente de todas as idades e com a aproximação das pessoas.
} 
possui alguma preocupação com o desenvolvimento responsável do turismo mesmo que não utilizando o termo Turismo Responsável? d) Como a responsabilidade e o Turismo Responsável são entendidos e percebidos pelos gestores públicos do Ministério do Turismo do Brasil (MTur)?

Por consequência, o trabalho partiu da seguinte questão de pesquisa: as atuais políticas públicas do MTur contemplam o Turismo Responsável nos seus diversos campos - ambiental, social, cultural e econômico? Tendo em vista essa questão central, o objetivo geral desse estudo foi analisar as políticas públicas em curso no MTur sob a ótica do Turismo Responsável (TR) com o intuito de identificar se existem, atualmente, no Brasil, políticas que possuam o seu pilar na responsabilidade, ou seja, iniciativas/ações conduzidas pelo Ministério do Turismo que sejam voltadas para uma política de Turismo Responsável - que estejam relacionadas de alguma maneira ao TR ou criadas sob a ótica dele.

Com a finalidade de abordar a problematização exposta anteriormente, essa dissertação apresenta-se dividida em sete capítulos, a saber: 1- Caminhos Metodológicos; 2- Denotações e Conotações de ser Responsável; 3- Apropriação da responsabilidade pelo Turismo; 4- As Políticas Públicas Federais de Turismo e sua evolução no Brasil; 5- A experiência de Políticas Públicas de Turismo Responsável no Mundo; 6- Apresentação e Análise das Políticas Públicas Responsáveis do Ministério do Turismo; e 7- A Responsabilidade na visão dos Gestores do Ministério do Turismo.

Optou-se por apresentar a metodologia utilizada para a concretização da pesquisa logo no primeiro capítulo, de tal modo que o leitor conseguisse entender todo o processo metodológico realizado, assim como, a sequência dos passos dados pela pesquisadora, antes da leitura da pesquisa propriamente dita. Portanto, o Capítulo 1 apresenta a metodologia escolhida, os movimentos de investigação e o método utilizado.

Para responder à questão de pesquisa - cerne da análise aqui proposta - bem como, aos objetivos desse estudo, iniciamos o desenvolvimento desse trabalho com uma averiguação sobre a responsabilidade e seus desdobramentos. Dessa forma, o Capítulo 2 discute a origem e os significados da responsabilidade, além de abordar suas relações com o respeito, o valor, a ética e a moral. E, por último, como a responsabilidade é refletida nas organizações.

Em seguida, no terceiro capítulo, fez-se um estudo sobre a apropriação da responsabilidade pelo turismo, assim como uma pesquisa sobre o contexto histórico de tal 
momento e os acontecimentos que antecederam o movimento mundial do Turismo Responsável. Após isso, foi feita uma revisão teórico-conceitual do TR, a qual perpassou por termos, tipos e segmentos do turismo a ele relacionados e, ainda, pelos conceitos de Turismo Sustentável, na busca da elucidação das diferenças existentes entre esses dois conceitos relativamente próximos.

Do mesmo modo, a construção de um referencial teórico sobre conceitos de políticas públicas e a importância destas para o turismo também demonstrou essencial para o desenvolvimento dessa dissertação e foi assunto tratado no Capítulo 4. Tudo isso forneceu subsídios para que abordássemos a investigação do histórico da gestão pública federal do turismo no Brasil já com um olhar do Turismo Responsável sob este, ainda nesse mesmo capítulo.

Posteriormente, no quinto capítulo, agora se aproximando mais do objetivo geral, foi realizada uma análise documental com a finalidade de identificar os pressupostos utilizados como fundamentos das políticas públicas de TR desenvolvidas por países pioneiros nesse tema - África do Sul e Gâmbia - e possíveis similaridades entre estas, até se chegar ao Capítulo 6 com o diagnóstico do contexto atual brasileiro e, finalmente, à análise das iniciativas atuais do MTur.

Além disso, com o intento de enriquecimento da pesquisa e, até mesmo, para responder a uma das questões geradoras do trabalho, foi realizado um trabalho de campo, por meio da aplicação de entrevistas semiestruturadas em dez membros do MTur. Os resultados destas foram analisados no último capítulo desse trabalho - o Capítulo 7.

O referencial teórico dessa pesquisa foi baseado principalmente em autores que vêm se dedicando ao estudo do turismo, da sustentabilidade, das políticas públicas de turismo e do Turismo Responsável tais como MOESCH (2002), COSTA (2013), BENI (2006), BORGES (2013), JOAQUIM (1997), LESLIE (2012) e GOODWIN (2005, 2012, 2014).

Com a finalidade de uma melhor visualização das etapas que foram concretizadas para a realização desse trabalho, consequentemente, oferecer clareza da sua estrutura, seus passos foram esquematizados na Figura 01 apresentada a seguir: 
Figura 01 - Etapas da dissertação

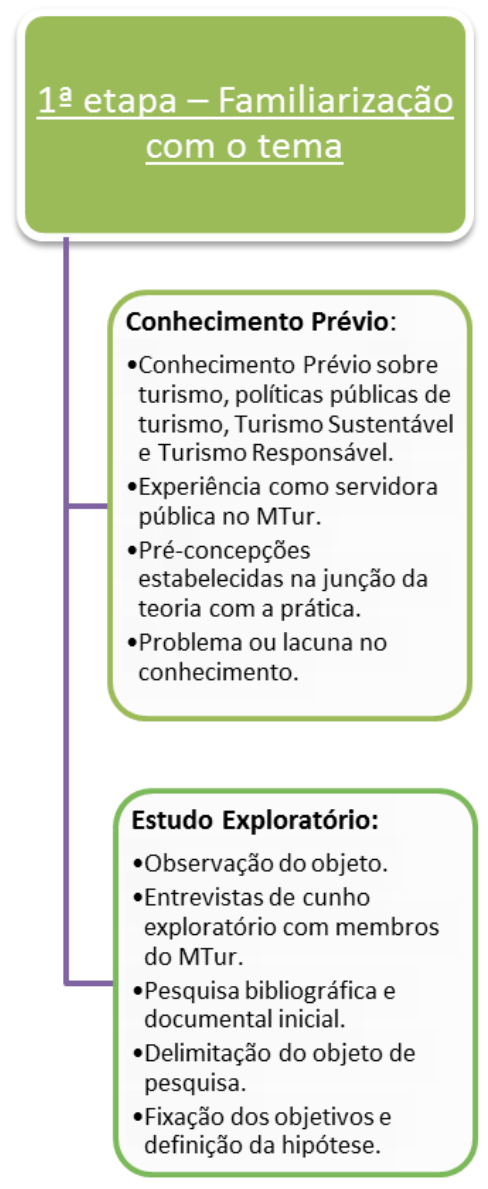

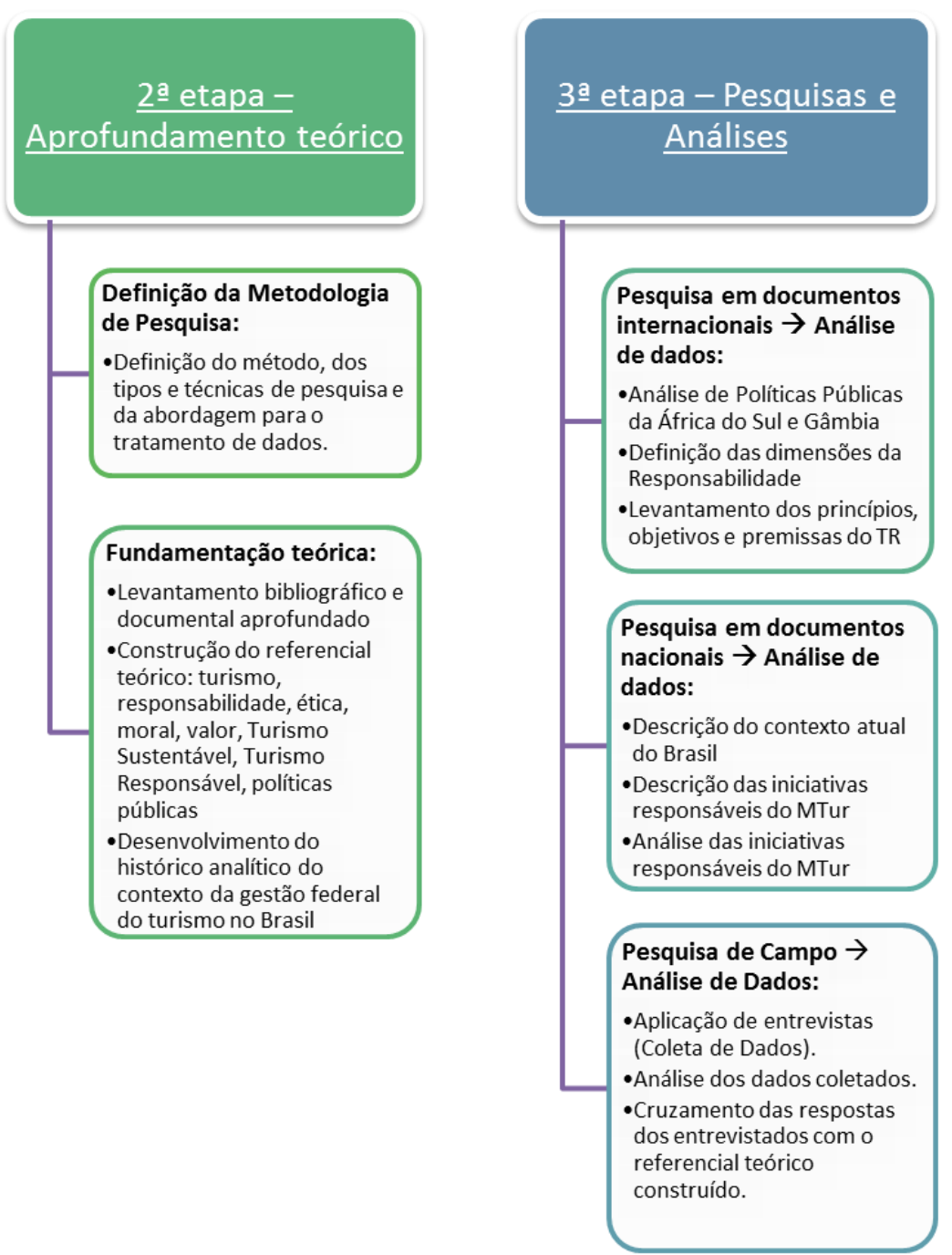

$\underline{4 \text { a etapa - Conclusão }}$ trabalho (refutação ou corroboração).
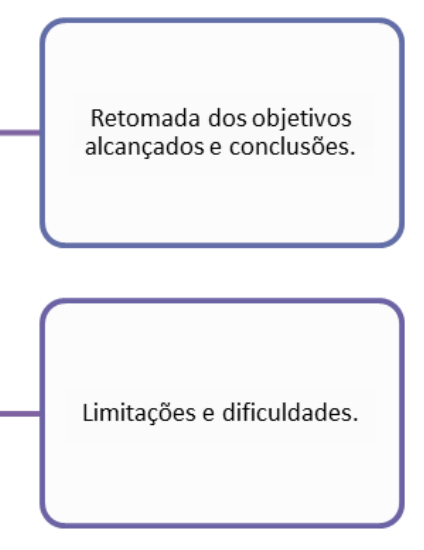

Fonte: Elaborada pela autora. 


\section{I - Objetivos}

\section{Objetivo Geral}

Analisar as iniciativas em curso no Ministério do Turismo sob a ótica do Turismo Responsável (TR).

\section{Objetivos específicos}

A concretização do objetivo geral demandou o alcance de quatro objetivos específicos, quais sejam:

- Refletir sobre a responsabilidade, enquadrando-a sob o enfoque do Turismo;

- Traçar um histórico das políticas públicas do Governo Federal do Brasil, sob o olhar do TR;

- Verificar os parâmetros utilizados pelas políticas públicas de Turismo Responsável adotados na África do Sul e em Gâmbia.

- Identificar as iniciativas voltadas para a responsabilidade no turismo instituídas pelo Ministério do Turismo.

\section{II - Justificativa}

O turismo é considerado um forte elemento de desenvolvimento devido aos seus potenciais efeitos econômicos. Os avanços do fenômeno turístico possibilitam aos economistas enxergarem nele o crescimento das taxas de desenvolvimento de distintas regiões, o que reforça "a vertente pragmática na qual o turismo é tomado como uma atividade de forte apelo econômico" (MOESCH, 2002, p.12).

O cenário econômico do turismo mostra-se promissor. As chegadas internacionais de turistas cresceram 4\% em 2012 e alcançaram o quantitativo de 1,035 bilhão de viajantes no mundo (OMT, 2013 apud BRASIL, 2013). No ano de 2011 cerca de 2,74 milhões de empregos diretos foram gerados pelo turismo e com estimativa de crescimento de 7,7\% para 2012 (WORLD TRAVEL \& TOURISM COUNCIL, 2013 apud BRASIL, 2013). No Brasil, a participação do turismo na economia representa $3,7 \%$ do PIB do país e de 2003 a 2009 o setor cresceu 32,4\%, enquanto a economia brasileira apresentou expansão de 24,6\% (BRASIL, 2013). 
Todavia, caso o turismo seja tratado apenas como mais uma atividade socioeconômica capitalista, orientada pelo lucro, o turismo pode não trazer desenvolvimento, mas sim provocar um crescimento econômico rápido e desordenado, em um processo desintegrador, o qual provoca rupturas sociais e ambientais (ARAÚJO, 2006).

Em 1989, Jost Krippendorf já havia alertado para a emergência de uma nova compreensão do turismo ao destacar a necessidade da instauração de um "novo" turismo, um "turismo melhor". Sua defesa pela humanização das viagens baseia-se na crença de que "o turismo só terá futuro se caminhar na direção de um humanismo maior". E completa "o importante é reconhecer que o turismo deve servir ao homem, e não ao contrário" (KRIPPENDORF, 1989, p. 175).

Junto com esse cuidado que se deve ter para não minimizar o turismo às preocupações exclusivamente dos ganhos econômicos, sabe-se, também, que a busca pela sustentabilidade é atualmente um desafio global (SACHS, 2002 apud COSTA, 2013). Assim sendo, a preocupação de como se aproveitar os efeitos do desenvolvimento do turismo de forma mais construtiva, não é mais uma questão do campo ideológico, mas sim do prático. Portanto, faz-se necessário possuir uma visão holística e estratégica, que integre todas as áreas envolvidas e afetadas pelo turismo econômica, social, cultural e ambiental - que sejam de interesse da comunidade, de maneira a atingir um processo autêntico de desenvolvimento regional sustentável.

Nesse sentido, consegue-se perceber o motivo pelo qual o assunto que envolve o desenvolvimento do turismo de forma responsável vem se tornando de extrema relevância em escala mundial. Em especial o debate sobre o "Turismo Responsável", visto que este se propõe a desenvolver "melhores lugares para se viver, e, dessa forma, melhores lugares para se visitar". E entre outras características "minimiza os impactos econômicos, ambientais e sociais negativos"; "gera maiores benefícios econômicos para a população local", "melhora o bem-estar das comunidades anfitriãs (...)", e, ainda, "envolve a população local nas decisões que afetam suas vidas" (Declaração da Cidade do Cabo, 2002). Assim, o Turismo Responsável pode contribuir com a comunidade e fazer com que o turismo se desenvolva para o benefício de todos, o que vai ao encontro das preocupações atuais vigentes.

Além da relevância mundial que o assunto atingiu atualmente, como foi exposto anteriormente, a seleção do tema dessa pesquisa e a definição do recorte 
espacial/temporal dessa investigação possuem relação, também, com a experiência da pesquisadora como servidora pública no Ministério do Turismo. O trabalho realizado por ela desde 2012, em diversas àreas dentro desse órgão, permitiu o despertar de outros olhares sobre a gestão do turismo no Brasil.

Da mesma forma, gerou uma inquietação nesse sujeito e uma necessidade de se descobrir qual é a verdadeira contribuição atual do órgão no incremento do turismo no país de uma forma que promova a responsabilidade em sua implantação, de maneira a colaborar de modo significativo para o desenvolvimento da comunidade receptora tantas vezes marginalizadas no crescimento do turismo; e ainda, de se desvendar se o trabalho proposto e desenvolvido pelo MTur contribui para um turismo endógeno, ético e responsável; sem esquecer, porém, dos limites do delineamento do objeto de pesquisa.

Ademais, o interesse em se estudar de forma mais densa a responsabilidade na gestão pública federal do turismo no Brasil veio igualmente como consequência da maturidade atingida pela pesquisadora durante os estudos desenvolvidos no Mestrado do CET/UnB e do seu despertar sobre a seriedade em se aprofundar nos estudos do "Turismo Responsável", tema este apresentado em uma das disciplinas do Curso. Essa importância justifica-se, visto que esse tema apresenta recente destaque mundial e demanda mais publicações e estudos sobre o assunto. No Brasil, praticamente não existe bibliografia específica sobre o Turismo Responsável.

Outro fator preponderante na escolha do tema foi a importância de pesquisas centradas na relação entre responsabilidade e turismo e a possibilidade de estudo das diferentes concepções da responsabilidade e suas representações nas políticas públicas do Ministério do Turismo, o que permite a disponibilização de mais conhecimento sobre a atuação desse órgão.

Dessa forma, fica evidente que a relevância do presente trabalho encontra-se tanto no âmbito acadêmico, quanto no profissional, uma vez que se busca contribuir para a clareza conceitual do termo Turismo Responsável, como também para potencialização da capacidade analítica em torno do tema, além de aprimorar o nível de informação sobre o assunto no Brasil. Ademais, a proposta de criação de categorias de análise enraizadas nas noções inerentes ao campo de estudo do TR, no lugar da importação de critérios de outros campos e/ou experiências, procura contribuir para uma pesquisa inovadora no País. 
Buscou-se, também, colaborar com o desenvolvimento de análises de publicações sobre um tema atual e importante, por meio de um trabalho que poderá servir de subsídio para tomadas de decisão do órgão federal representante do turismo no Brasil. 
Cwiosidade, criatividade, disciplina e especialmente paixão são algumas exigências para o desenvolvimento de um trabalho criterioso, baseado no confronto permanente entre o desejo e a realidade.

$$
\text { Mirian Soldenberg }
$$


Este capítulo busca apresentar a metodologia utilizada para a construção desse trabalho, de maneira a esclarecer o leitor sobre o caminho percorrido pela autora para que os objetivos propostos fossem alcançados.

Esse assunto é item de suma relevância para qualquer trabalho científico, visto que uma investigação científica produz conhecimento científico por meio de seus métodos, e é isso que o difere do conhecimento empírico, ou senso comum (DENCKER, 2007; GIL, 1999). Deste modo, para que o conhecimento seja considerado como científico é indispensável identificar o caminho cursado para atingi-lo. E, o caminho a ser percorrido para se chegar a determinado fim é o próprio método. Ou seja, o método científico é o conjunto de procedimentos intelectuais e técnicos adotados para se atingir o conhecimento (GIL, 1999).

Segundo Lakatos e Marconi (2003), o método é o conjunto das atividades sistêmicas e racionais que proporciona obter conhecimentos válidos e verdadeiros ao esquematizar o caminho a ser seguido. É ele que ressalta os erros e ampara as decisões dos cientistas. Assim sendo, é possível afirmar que o método científico é o conjunto de processos ou operações mentais que devem ser empregadas na investigação, constituindo-se da linha de raciocínio seguida no processo de pesquisa. Já a metodologia evidencia quais as técnicas devem ser adotadas para se percorrer tal caminho. Ela é a viagem que se faz na busca de um objetivo particular.

Para nortear a presente pesquisa, foi determinado como objeto de estudo as políticas públicas do Ministério do Turismo e como recorte espacial/temporal a atualidade, ou seja, as políticas públicas que estejam em curso no MTur durante o desenvolvimento da pesquisa.

Com a finalidade de uma melhor organização do capítulo "Caminhos Metodológicos", por conseguinte, a possibilidade de proporcionar total clareza da metodologia utilizada nessa pesquisa e evidenciar as etapas metodológicas de sua construção, ele foi subdividido em seções, as quais apresentam o método utilizado e o tipo de pesquisa realizada. Além disso, incluem as diversas técnicas de pesquisa empregadas e o tratamento usado para análise e abordagem dos dados coletados. 


\subsection{MÉTODO HIPOTÉTICO - DEDUTIVO}

A pesquisa científica é a concretização de um estudo com planejamento, sendo que o método de abordagem do problema é o que caracteriza o aspecto científico da investigação. Esta objetiva encontrar respostas para questões diante da aplicação do método científico (LAKATOS e MARCONI, 2003).

O método de abordagem empregado nessa pesquisa foi o Hipotético-Dedutivo. Seu uso nas pesquisas em ciências sociais mostra-se eficiente, uma vez que, como fundamenta Gil (1989), seus princípios são mostrados por um grande número de autores para a construção de modelos lógicos de pesquisa em ciências sociais.

Esse método foi definido por Karl Popper a partir de críticas à indução (GIL, 1999). E sua linha de raciocínio pode ser explicada no seguinte trecho:

(...) quando os conhecimentos disponíveis sobre determinado assunto são insuficientes para a explicação de um fenômeno, surge o problema. Para tentar explicar as dificuldades expressas no problema, são formuladas conjecturas ou hipóteses. Das hipóteses formuladas, deduzem-se consequências que deverão ser testadas ou falseadas. Falsear significa tornar falsas as consequências deduzidas das hipóteses. Enquanto no método dedutivo se procura a todo custo confirmar a hipótese, no método hipotético-dedutivo, ao contrário, procuram-se evidências empíricas para derrubá-la (GIL, 1999, p. 30).

Portanto, ao se verificar essa lógica apresentada, conseguimos entender que a pesquisa científica com abordagem hipotético-dedutiva inicia-se com a formulação de um problema, ou seja, com uma lacuna no conhecimento científico. Após essa constatação há a formulação de hipóteses, que por um processo de dedução, gera consequências, as quais são testadas na tentativa de falseá-las. Podemos apresentar o método hipotético-dedutivo a partir do esquema mostrado na Figura 02, a seguir.

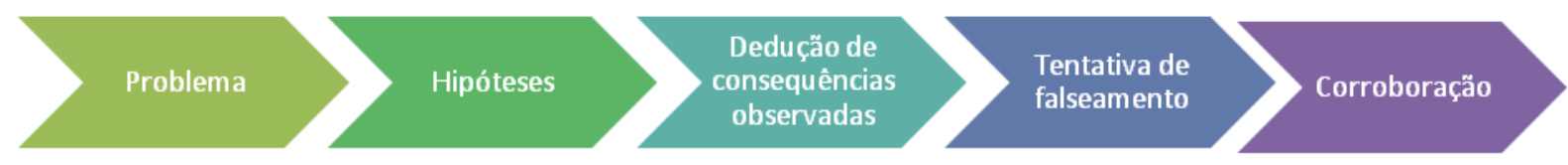

Figura 02 - As fases do método Hipotético Dedutivo Fonte: Adaptado de Gil (1999) e Lakatos e Marconi (2003). 
Para melhor entendimento da linha de raciocínio desse método e, assim, explicitar com mais nitidez como ele foi aplicado para a realização dessa pesquisa, recorreu-se também a Lakatos e Marconi (2003), as quais explicam que o surgimento do problema infere de um contexto antecedente, que consiste no conhecimento prévio ou na expectativa do pesquisador. Afirmam que o problema precisa ser descrito de forma precisa e clara, e que ele é o direcionador do estudo a partir do momento que evidencia o que é ou não relevante para a pesquisa, além de demonstrar quais os dados que devem ser analisados.

Vale ressaltar, que essas mesmas autoras ainda explicam que, posteriormente ao problema há um momento de observação que não é aleatório, mas sim direcionado, já com um objetivo. É uma fase cautelosa em que é observado determinado aspecto do universo, objeto da pesquisa, para então surgir a segunda fase do método hipotéticodedutivo, a hipótese, também chamada por elas de conjectura ou suposição. Esta se trata de uma solução que é apresentada na forma de uma proposição (normalmente no formato "Se... então") passível de teste, e que é formulada para se explicar ou para se previr o que despertou a curiosidade no cientista (LAKATOS e MARCONI, 2003).

Da mesma forma que Gil (1999), as autoras Lakatos e Marconi (2003) também explicam que o método hipotético-dedutivo exige uma fase de eliminação de erros com a realização de testes e tentativas de falseamento das consequências deduzidas da hipótese. Ao final, existe a fase da verificação da hipótese, que resultará no seu refutamento ou na sua corroboração. Caso seja refutada, dá-se início novamente ao ciclo das fases do método, com a construção de outra hipótese.

Para situar a presente pesquisa nas etapas do método de Popper, pelo qual ela foi balizada, será explicado o problema de pesquisa deste trabalho e apresentada a hipótese que foi levantada para a aplicação de tal método. No decorrer do estudo, com base nessa hipótese, serão deduzidas consequências a serem testadas também durante o seu desenvolvimento. Por fim, haverá a verificação se a hipotése foi corroborada pela pesquisa desenvolvida.

Assim, essa pesquisa teve início com o aparecimento de um problema ocasionado pelas pré-concepções estabelecidas pela pesquisadora, na junção da teoria - sua graduação e pós-graduação em turismo - com a prática - sua experiência no MTur. Percebeu em meio às evidências da importância de se planejar o turismo com responsabilidade - o que já não era diferente do discurso estudado há dez anos em sua 
graduação - um reflexo contemporâneo dessa preocupação nos órgãos oficiais de gestão do turismo de vários países no mundo (África do Sul, Gâmbia, Índia, Espanha, Inglaterra, Alemanha, Belize, Oman, entre outros), na medida em que vários começaram a desenhar políticas nacionais de Turismo Responsável, o que acarretou o movimento do TR. Ao mesmo tempo, constatou que no MTur não havia nenhum documento que fazia referência explícita a esse termo. Estaria então o MTur fora do padrão das preocupações atuais com a gestão do turismo? Ou não, ele somente não usa o termo, mas possui princípios, objetivos e premissas do Turismo Responsável de maneira implícita em suas iniciativas?

Como resultado dessa problemática, surgiu a questão de pesquisa: as atuais políticas públicas do MTur contemplam de alguma forma o Turismo Responsável nos seus diversos campos - ambiental, social, cultural e econômico?

Diante disso, desenvolveu-se um estudo exploratório, no qual o objeto da pesquisa foi observado, o que possibilitou o desenho da seguinte hipótese: Sendo o Ministério do Turismo o órgão responsável pela gestão federal do turismo no Brasil e se o Turismo Responsável é um pilar fundamental da gestão contemporânea do turismo no mundo, então o MTur está incorporando de alguma maneira o Turismo Responsável no delineamento de sua gestão.

O falseamento dessa hipótese e de algumas de suas consequências dedutivas estaria em constatações como: O Turismo Responsável não é um pilar fundamental da gestão contemporânea do turismo no mundo, portanto o MTur não precisa preocupar-se com sua incorporação nas suas políticas públicas; ou, o Turismo Responsável é sim um pilar fundamental da gestão contemporânea do turismo no mundo, porém o MTur não está seguindo os padrões/as tendências internacionais de planejamento e gestão do turismo, o que iria de encontro com os valores atuais e enfraqueceria a credibilidade do órgão.

Ao seguir a lógica do método, e assim desenvolver o trabalho de maneira a testar essa hipótese - com a construção de uma fundamentação teórica e a realização de pesquisas e análises -, foi preciso recorrer-se a determinados tipos e a algumas técnicas de pesquisa. A seguir, esses procedimentos serão discutidos. 


\subsection{TIPOS DE PESQUISA}

Existem várias formas de se classificar as pesquisas científicas. Isso se deve ao fato que os critérios utilizados para a classificação dos tipos de pesquisa mudam de acordo com a abordagem utilizada, com os interesses, com os campos estudados, com as metodologias empregadas, ou até mesmo com os objetos de estudo.

Nessa pesquisa recorremos à um esquema de classificação apresentada por Prodanov e Freitas (2013), em sua obra Metodologia do trabalho científico: Métodos e Técnicas da Pesquisa e do Trabalho Acadêmico. Essa escolha deu-se pelo fato dos autores conseguirem expor as formas clássicas de categorização de maneira acessível e didática. A Figura 03 apresenta esses tipos de pesquisa.

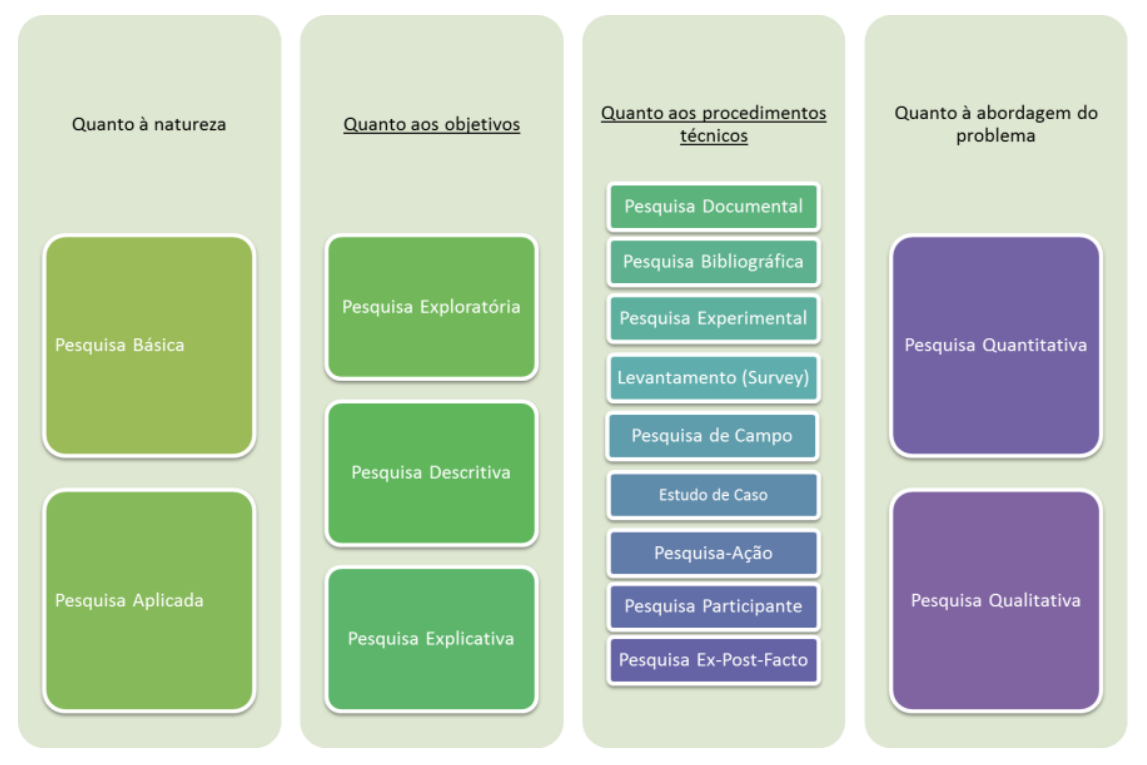

Figura 03 - Tipos de Pesquisa Científica

Fonte: Adaptado de Prodanov e Freitas (2013).

Baseado nesse esquema, verificamos que essa dissertação é classificada metodologicamente sob o aspecto de sua natureza como uma pesquisa aplicada. E do ponto de vista dos seus objetivos é classificada como um estudo exploratório e descritivo. Todos esses tipos de pesquisa serão explicados separadamente a seguir, na respectiva ordem aqui exposta. 


\subsubsection{Pesquisa Aplicada}

Uma pesquisa aplicada "objetiva gerar conhecimentos, para aplicação prática, dirigidos à solução de problemas específicos. Envolve verdades e interesses locais". O que a diferencia da pesquisa básica, é o fato que esta "objetiva gerar conhecimentos novos úteis para o avanço da ciência sem aplicação prática prevista. Envolve verdades e interesses universais" (PRODANOV; FREITAS, 2013, p. 51).

Com essa explicação fica perceptível que essa pesquisa trata-se de uma pesquisa aplicada, pois ao se verificar pontos já explicitados anteriormente - tais como a apresentação do tema, seu delineamento e seus objetivos - conclui-se que seu objetivos tem desdobramentos práticos, seu problema é específico e não possui um interesse universal.

\subsubsection{Pesquisa Exploratória}

Segundo Lakatos e Marconi (2003) a pesquisa exploratória acontece quando a investigação encontra-se na fase preliminar. Ela possui como intento a busca por mais informações sobre o assunto que será investigado, e por isso possibilita sua definição e seu delineamento, ou seja, esse tipo de pesquisa facilita a delimitação do tema da pesquisa, orienta a fixação dos objetivos e a formulação das hipóteses, ou ainda, auxilia a descobrir um novo tipo de enfoque para o assunto.

É importante explicar que, a pesquisa exploratória "é aquela que se caracteriza pelo desenvolvimento e esclarecimento de ideias, com o objetivo de oferecer uma visão panorâmica, uma primeira aproximação a um determinado fenômeno que é pouco explorado." (GONSALVES, 2003, p. 67).

Esse tipo de pesquisa abrange um planejamento flexível, o que permite o estudo do tema sob diversos ângulos e aspectos. E, para amparar na construção e no aperfeiçoamento das ideias, durante a sua execução, ela envolve um levantamento de dados bibliográficos preliminares e a realização de entrevistas (DENCKER, 2007; LAKATOS; MARCONI, 2003).

No caso específico do presente trabalho, foi realizada, durante os meses de janeiro a maio de 2013, uma observação do objeto com a concretização de entrevistas de cunho exploratório com membros do MTur e com a efetivação de uma pesquisa 
bilbiográfica e documental inicial. Tal processo de reconhecimento visou obter uma ideia inicial sobre o tema e o estado da arte, o que permitiu descobrir novas ideias e perspectivas a respeito do objeto de estudo; além de travar contatos necessários à efetuação das pesquisas posteriores.

Com essa prática, foi possível cumprir o que a pesquisa exploratória se propõe a auxiliar, visto que se conseguiu delimitar o objeto de estudo, definir os objetivos da pesquisa, identificar os desafios a serem ultrapassados pela pesquisadora, como também, formular a hipótese da pesquisa e selecionar o método, tipos e técnicas mais adequados para o cumprimento dos objetivos do estudo.

\subsubsection{Pesquisa Descritiva}

A pesquisa descritiva, por sua vez, "objetiva descrever as características de um objeto de estudo. [...] Nesse caso, a pesquisa não está interessada no porquê, nas fontes do fenômeno; preocupa-se em apresentar suas características" (GONSALVES, 2003, p. 65).

De acordo com o que Lakatos e Marconi (2003) destacam, quando o pesquisador somente registra e descreve os fatos observados sem fazer interferências neles, ele está realizando uma pesquisa descritiva. Ressaltam, igualmente, que ela procura classificar, explicar e interpretar fatos que ocorrem. Nesse tipo de pesquisa "os fatos são observados, registrados, analisados, classificados e interpretados, sem que o pesquisador interfira sobre eles, ou seja, os fenômenos do mundo físico e humano são estudados, mas não são manipulados pelo pesquisador" (PRODANOV; FREITAS, 2013, p. 52).

Corroborando com a explicação de Gonsalves (2003), citada anteriormente, esses últimos autores explicam de forma bastante clara do que se trata esse tipo de pesquisa:

Visa descrever as características de determinada população ou fenômeno ou o estabelecimento de relações entre variáveis. Envolve o uso de técnicas padronizadas de coleta de dados: questionário e observação sistemática. Assume, em geral, a forma de Levantamento. Tal pesquisa observa, registra, analisa e ordena dados, sem manipulá-los, isto é, sem interferência do pesquisador. Procura descobrir a frequência com que um fato ocorre, sua natureza, suas características, causas, relações com outros fatos. Assim, para coletar tais dados, utiliza-se de técnicas específicas, dentre as quais se 
destacam a entrevista, o formulário, o questionário, o teste e a observação. (PRODANOV; FREITAS, 2013, p.52)

Com isso exposto, fica mais clara a compreensão de que esse tipo de pesquisa foi utilizado em duas etapas ${ }^{18}$ essenciais desse estudo: na $2^{2}$ etapa (Aprofundamento Teórico), quando se construiu o referencial teórico da pesquisa e se resgatou o histórico do contexto da gestão federal do turismo no Brasil; e na $3^{a}$ etapa (Pesquisas e Análises), tanto na pesquisa do contexto atual do Brasil, quanto das iniciativas responsáveis do MTur.

Por fim, é importante destacar mais uma observação de Prodanov e Freitas (2013, p.53). Eles afirmam que "as pesquisas descritivas são, juntamente com as pesquisas exploratórias, as que habitualmente realizam os pesquisadores sociais preocupados com a atuação prática", fato este que se encaixa perfeitamente com as preocupações dessa dissertação - o desempenho prático.

\subsection{TÉCNICAS DE PESQUISA}

Ainda com base na classificação apresentada por Prodanov e Freitas (2013) e representada pela Figura 03, verifica-se que sob o enfoque dos procedimentos técnicos pode-se dizer que, para a concretização dessa dissertação, tanto a Pesquisa Bibliográfica quanto a Documental foram realizadas; além dessas também houve uma terceira, a Pesquisa de Campo. Essas técnicas de pesquisa serão explicadas a seguir, respectivamente na ordem aqui citadas.

\subsubsection{Pesquisa Bibliográfica}

A pesquisa bibliográfica é elaborada a partir de material já publicado, com a finalidade de colocar o pesquisador em contato direto com todo material já escrito, falado ou filmado sobre o objeto da pesquisa. Inclusive eventos, como apresentações e debates, que tenham sido transcritos de alguma forma, publicados ou gravados. (LAKATOS; MARCONI, 2003).

\footnotetext{
${ }^{18}$ Etapas estas apresentadas e explicadas na Figura 01; vide p. 29 dessa dissertação.
} 
Para o desenvolvimento do presente estudo, essa técnica de pesquisa envolveu a consulta de livros, artigos científicos, websites, dissertações, gravações de um seminário ${ }^{19}$ e publicações em periódicos nacionais e estrangeiros.

Ela foi realizada durante as duas primeiras etapas ${ }^{20}$ de desenvolvimento da pesquisa - na de familiarização com o tema e na de aprofundamento teórico. Sendo que na primeira etapa, ela foi essencial para o estudo exploratório, de tal modo a auxiliar no levantamento preliminar de dados, na revisão inicial da bibliografia existente e na definição do objeto de estudo.

Já na segunda etapa, essa técnica foi fundamental para o entendimento da teoria sobre metodologia de pesquisa, bem como para a construção da fundamentação teórica. Esta foi estabelecida por meio de uma pesquisa bibliográfica aprofundada, a qual esclareceu dados históricos e conceitos importantes para a constituição do referencial teórico, que no caso abarcou principalmente a teoria sobre turismo, responsabilidade, Responsabilidade Social em Empresas, sustentabilidade, Turismo Sustentável, Turismo Responsável, políticas públicas e políticas públicas de turismo.

Faz-se essencial ressaltar que durante essa pesquisa houve muitas dificuldades em se encontrar livros específicos de teoria sobre o Turismo Responsável, principalmente na literatura nacional. Praticamente toda a literatura sobre esse tema ficou baseada em títulos internacionais de língua inglesa.

Ao se buscar livros com esse tema no Brasil, usualmente achamos livros que tratavam de segmentos específicos como ecoturismo ou turismo de aventura, ou então somente que discutia sobre a teoria ou a importância da Responsabilidade Social nas Empresas. E na pesquisa internacional percebeu-se que a teoria concentra-se em um mesmo autor, o professor Harold Goodwin, ou então trata mais de abordagens da prática do TR, como as publicações de livros de compilamentos de artigos com estudos de casos ou estudos focados na prática.

A terceira etapa da dissertação (Etapa "Pesquisas e Análises"), por envolver análises baseadas em documentos nacionais e internacionais, foi possível por meio da pesquisa documental que será abordada em seguida.

\footnotetext{
${ }^{19}$ Simpósio Turismo Responsável nos Destinos. Evento realizado dia 28 de abril de 2014, no Centro de Excelência em Turismo - CET/UnB, Brasília-DF.

${ }^{20}$ Etapas estas apresentadas e explicadas na Figura 01; vide p. 29 dessa dissertação.
} 


\title{
1.3.2 Pesquisa Documental
}

A pesquisa documental pode ser explicada como:

\begin{abstract}
Um conjunto de procedimentos que visa selecionar os documentos pertinentes ao tema estudado e proceder à respectiva anotação e fichamento das referências e dos dados dos documentos para que sejam posteriormente utilizados na redação de um trabalho acadêmico (STUMPF apud BARROS; DUARTE, 2008, p. 51).
\end{abstract}

Em função de suas características, ela pode ser confundida com a pesquisa bibliográfica. Mas para que esse engano não aconteça recorremos a uma explicação dada por Gil (1999), que esclarece que essa diferença está na natureza da fonte utilizada, uma vez que a pesquisa bibliográfica baseia-se em materiais nos quais os autores já fizeram contribuições sobre o assunto, enquanto que a pesquisa documental fundamenta-se em fontes que ainda não receberam nenhum tratamento analítico ou que proporcionem a possibilidade de serem reelaborados de acordo com os objetivos da pesquisa. Temos como exemplos documentos oficiais, reportagens de jornal, filmes, gravações, relatórios de pesquisa, tabelas estatísticas, entre outros.

Prodanov e Freitas (2013) explicam o que são documentos no trecho que citamos a seguir:

\begin{abstract}
Entendemos por documento qualquer registro que possa ser usado como fonte de informação, por meio de investigação, que engloba: observação (crítica dos dados na obra); leitura (crítica da garantia, da interpretação e do valor interno da obra); reflexão (crítica do processo e do conteúdo da obra); crítica (juízo fundamentado sobre o valor do material utilizável para o trabalho científico) (PRODANOV; FREITAS, 2013, p. 56).
\end{abstract}

Essa explicação nos é essencial, visto que os autores detalham todos os procedimentos realizados na pesquisa documental dessa dissertação: observação, leitura, reflexão e crítica dos documentos. No caso específico desse trabalho, a pesquisa documental consistiu na análise de documentos oficiais dos países-referência - África do Sul e Gâmbia, como, por exemplo, os documentos de políticas públicas e de planejamento do turismo dos respectivos países, tais como o Plano Nacional de Turismo Responsável da África do Sul $^{21}$ (2002), a Política de Turismo Responsável da Gâmbia ${ }^{22}$

\footnotetext{
${ }^{21}$ South African National Responsible Tourism Guidelines.
} 
(2002), e a Declaração da Cidade do Cabo para o Turismo Responsável ${ }^{23}$ (2002). Como também, a análise de documentos do Ministério do Turismo, como o Plano Nacional de Turismo (2013-2016) e documentos referentes às iniciativas e programas, tais como cartilhas, manuais, folders e livretos informativos.

A seleção desses dois países - África do Sul e Gâmbia - para servirem como países-referência do presente estudo, deu-se por proporcionarem um rico repertório consolidado sobre o assunto. Especificamente, a opção pela África do Sul foi feita por ter sido a precursora em políticas públicas de Turismo Responsável e também por prover a maior quantidade de documentos relacionados ao tema. Já a escolha de Gâmbia, foi feita pelo fato de ter sido um dos primeiros países que criou uma Política Nacional de TR, já em 2002, e por ser também um país que busca a inclusão social e melhores oportunidades para a população por meio do desenvolvimento do turismo, assim como o Brasil.

Este levantamento compôs um dossiê de informações que delinearam os preceitos que uma política pública de turismo precisa levar em conta para ser considerada pela teoria uma iniciativa responsável. Tal passo foi essencial para nossa proposta de pesquisa, já que foram justamente estes os critérios para a análise das políticas públicas brasileiras de turismo. Dessa maneira, foi possível verificar a hipótese de haver ou não relações de semelhança entre os critérios usados para a formulação de políticas públicas entendidas como de Turismo Responsável nos países-referência e os critérios utilizados no Brasil, e descobrir se este país possui políticas com princípios responsáveis, apesar de não possuir uma política nacional específica de Turismo Responsável.

\subsubsection{Pesquisa de Campo}

A pesquisa de campo pode ser entendida como:

Aquela utilizada com o objetivo de conseguir informações e/ou conhecimentos acerca de um problema para o qual procuramos uma resposta, ou de uma hipótese, que queiramos comprovar, ou, ainda, descobrir novos fenômenos ou as relações entre eles. Consiste na observação de fatos e fenômenos tal como ocorrem espontaneamente, na coleta de dados a eles referentes e no registro de

\footnotetext{
${ }^{22}$ Policy for Responsible Tourism in Gambia.

${ }^{23}$ The Cape Town Declaration.
} 
variáveis que presumimos relevantes, para analisá-los (LAKATOS; MARCONI, 2003, p.186).

Na presente dissertação a pesquisa de campo foi realizada como uma análise de suporte do trabalho, uma forma de enriquecimento da pesquisa com a coleta e análise de informações sobre o tema estudado a partir de uma visão dos próprios atores da política nacional de turismo do Brasil. Assim sendo, a realização do estudo de campo objetivou conseguir informações, averiguar fatos e determinar opiniões de gestores públicos do MTur a respeito do Turismo Responsável e a relação deste com as políticas e com os programas instituídos no país. Igualmente, teve o intuito de acessar seu nível de engajamento com o TR e/ou seu conhecimento sobre o tema.

O estudo de campo foi realizado por meio de entrevistas:

A entrevista é um encontro entre duas pessoas, a fim de que uma delas obtenha informações a respeito de determinado assunto, mediante uma conversação de natureza profissional. É um procedimento utilizado na investigação social, para a coleta de dados ou para ajudar no diagnóstico ou no tratamento de um problema social (LAKATOS; MARCONI, 2003, p.195).

No caso específico dessa dissertação, as entrevistas foram semiestruturadas e aplicadas pela pesquisadora, durante os meses de novembro e de dezembro de 2013, e no mês de janeiro de 2014, junto a dez gestores públicos do Ministério do Turismo. Desses 10 (dez), 2 (dois) são Diretores, 2 (dois) Coordenadores e 6 (seis) Coordenadores - Gerais. Chegamos a esse número de entrevistados, ao selecionarmos pelo menos um representante das três Secretarias existentes na estrutura administrativa do MTur (Secretaria Executiva, Secretaria Nacional de Políticas de Turismo e Secretaria Nacional de Programas de Desenvolvimento do Turismo); como também, no mínimo, um gestor ligado a cada departamento que executa alguma iniciativa relacionada ao tema de estudo. Tal seleção deu-se após o levantamento teórico realizado pela autora e a análise documental dos programas do Governo voltados à temática.

O mês de fevereiro também estava reservado para aplicação de algumas entrevistas, contudo não foram efetivadas. Isto porque, no primeiro momento pretendiase entrevistar além de coordenadores e diretores desse órgão, membros do mais auto escalão do MTur, como o Secretário Executivo e Assessores do Ministro. Porém, no período previsto para a realização das entrevistas, houve uma mudança desses membros e os contatos estabelecidos anteriormente foram perdidos. Com a 
movimentação da troca do então Ministro Gastão Vieira do MTur e de sua equipe não foi possível estabelecer agenda para aplicação das entrevistas para tais pessoas.

Apesar disso, entende-se que a qualidade da pesquisa não ficou comprometida, visto que os membros entrevistados são peças-chave do órgão, pois em sua maioria estão em coordenações e departamentos diretamente ligados às iniciativas de interesse desse estudo, e trabalharam na formulação das políticas e dos programas, e atualmente em sua efetivação, divulgação e acompanhamento.

É válido ressaltar que os entrevistados foram selecionados de forma oportuna, não probabilística por acessibilidade. De acordo com Gil (1999), nesse tipo de pesquisa é estimável a prática de entrevistas informais com elementos-chave, por exemplo, especialistas no tema em estudo; líderes formais ou informais; ou personalidades destacadas. Por se enquadrar adequadamente na estratégia desse estudo, decidiu-se que a melhor opção para atingir os objetivos dessa pesquisa de campo seria a seleção da amostragem de forma intencional.

O roteiro de entrevista consistiu na formulação de 5 (cinco) perguntas abertas, às quais os entrevistados respondiam com seu próprio vocabulário, sem limite de tempo para as respostas. Todas as entrevistas foram gravadas com autorização dos entrevistados, e posteriormente transcritas pela pesquisadora, para então serem trabalhadas na análise.

A análise das entrevistas teve uma abordagem qualitativa, o que permitiu a utilização, para a realização dessas entrevistas, da técnica conhecida como "entrevista em profundidade", a qual se compreende como:

\begin{abstract}
A técnica qualitativa que explora um assunto a partir da busca de informações, percepções e experiências de informantes para analisá-los e apresentá-los de forma estruturada. Entre as principais qualidades dessa abordagem está a flexibilidade de permitir ao informante definir os termos da resposta e ao entrevistado ajustar livremente as perguntas. Este tipo de entrevista procura intensidade nas respostas, não-quantificação ou representação estatística (DUARTE apud BARROS; DUARTE, 2008, p. 62).
\end{abstract}

As entrevistas realizadas também foram analisadas pela técnica de análise de conteúdo, com base na afirmação que a "prática articulada mais comum de pesquisa combina a coleta de dados através de entrevistas individuais com a técnica para o seu tratamento conhecida como ‘análise de conteúdo'” (SÁ, 1998, p. 86). [grifos nossos].

Essas técnicas de tratamento dos dados serão explicadas a seguir. 


\subsubsection{Tratamento dos dados - abordagem}

A pesquisa foi desenvolvida, sobretudo, a partir da análise de conteúdo dos documentos mencionados anteriormente com abordagem qualitativa.

\subsubsection{Pesquisa Qualitativa}

Como já foi afirmada anteriormente, a forma de análise do objeto dessa dissertação é de natureza qualitativa, isso porque tanto os documentos estudados quanto as políticas públicas brasileiras analisadas foram conteúdos pesquisados com a intenção de se obter os dados de maneira descritiva, o que, de acordo com Neves (1996), enquadra-se em um estudo de natureza qualitativa.

No caso desse trabalho não somente isso justifica a escolha pela abordagem qualitativa. As características referentes ao tipo de dados coletados fazem com que os métodos qualitativos sejam mais apropriados, já que o fenômeno em estudo é complexo, de natureza social e não tende à quantificação.

Manning (1979a apud NEVES, 1996) explica que o trabalho de descrição tem caráter fundamental em um estudo qualitativo, pois é por meio dele que os dados são coletados. Os pesquisadores tendem a analisar seus dados indutivamente e o processo e seu significado são os focos principais de abordagem. Essa técnica de pesquisa "não emprega instrumental estatístico para análise dos dados; seu foco de interesse é amplo e parte de uma perspectiva diferenciada da adotada pelos métodos quantitativos" (NEVES, 1996, p.01). Além disso, "a interpretação dos fenômenos e a atribuição de significados são básicas no processo de pesquisa qualitativa. $O$ ambiente natural é a fonte direta para coleta de dados e o pesquisador é o instrumento-chave" (PRODANOV; FREITAS, 2013, p. 70).

Ao verificarmos a explicação da pesquisa qualitativa feita por Prodanov e Freitas (2013, p.70), percebemos que ela considera que "há uma relação dinâmica entre o mundo real e o sujeito, isto é, um vínculo indissociável entre o mundo objetivo e a subjetividade do sujeito que não pode ser traduzido em números".

A presente dissertação preocupa-se em analisar e interpretar os dados com foco em seu conteúdo e não na forma numérica, uma vez que objetivamos entender 
princípios e premissas de Turismo Responsável implícitos nas políticas públicas e a visão e conhecimento dos gestores sobre este conceito.

Vale destacar que nas pesquisas em ciências sociais ao se trabalhar com significados, motivações, valores e crenças - que não podem ser simplesmente reduzidos às questões quantitativas por responderem a noções muito particulares - é mais interessante adotar uma posição conciliatória por meio da integração entre os métodos quantitativo e qualitativo, uma vez que um não substitui o outro, pelo contrário, eles se complementam (MINAYO, 2002). E foi o que fizemos nessa dissertação - apesar desta possuir uma abordagem predominantemente qualitativa, em alguns momentos na descrição da análise das respostas dos entrevistados, foi destacado, por exemplo, a quantidade de respondentes que possuíam as mesmas ideias implícitas em seus discursos.

Diante da utilização da abordagem qualitativa, identificou-se que a "análise de conteúdo" seria a melhor técnica para se avaliar os dados coletados. O motivo dessa escolha e a explicação do que se trata essa técnica serão expostos em seguida.

\subsubsection{Análise de Conteúdo}

O processo de análise dos dados inicia-se após a sistematização dos elementos coletados. O objetivo dessa análise seria agrupar as informações de maneira coerente e organizada para que seja possível alcançar os objetivos da pesquisa (Dencker, 2009).

De acordo com Bardin (1997), a análise de conteúdo enquadra-se numa prática de pesquisa de enfoque crítico e epistemologicamente amparado numa compreensão em que o sujeito é ativo e produz o conhecimento. A finalidade desse método é a dedução de conhecimentos relativos às categorias de produção e de recepção das mensagens, dedução esta que busca indicadores, que podem ser quantitativos ou não.

Richardson (1985) explica que "toda comunicação que implica a transferência de significados de um emissor a um receptor pode ser objeto de análise de conteúdo". E por esse motivo ele assegura que a análise de conteúdo pode ser aplicada não somente a documentos escritos, como também a objetos, elementos iconográficos, documentos fotográficos, cinematográficos, entre outros. 
Bardin (1997) acrescenta que a análise de conteúdo é frequentemente usada para analisar e investigar materiais qualitativos com 0 intuito de compreender comunicações ou discursos, aprofundar suas propriedades gramaticais em relação as suas ideias, bem como extrair deles os seus aspectos mais acentuados. Baseia-se numa visão analítica e dinâmica da linguagem. A fim de que a linguagem seja entendida como a manifestação da experiência humana.

Para a execução do método de maneira correta e com segurança, nas três análises que realizamos para esse trabalho seguimos os procedimentos da análise de conteúdo divididos em três fases: primeiramente, a pré-análise dos dados coletados; em seguida, a exploração do material e o tratamento dos resultados; e, por último, a inferência junto com a interpretação (BARDIN, 1997).

Ressalta-se que os dados coletados nas entrevistas foram analisados de maneira a agrupar as respostas semelhantes. Além disso, deu-se destaque a trechos das falas dos entrevistados que mereceram ênfase, tendo como pano de fundo o referencial teórico construído, assim como as informações apreendidas pela análise da pesquisa documental.

Acreditamos que agora - após a introdução ao tema de pesquisa, exposição do objeto, da problematização e dos objetivos que envolvem a presente dissertação, bem como da descrição da estrutura do trabalho, e, nesse primeiro capítulo, com a explicação de todos os procedimentos metodológicos utilizados para a realização desse estudo - podemos adentrar-nos às escritas específicas da pesquisa em si, inicialmente, com a apresentação de sua fundamentação teórica, conteúdo este dos três próximos capítulos. 
Qs human beings, we are endawed with freedom of choice, and we cannot shuffle off our responsibility upon the shoulaers of $\mathcal{G}_{0}$ or nature. We must shoulder it ourselves. It is up to us.

Q.. . Toynbee 
Quando se fala de Turismo Responsável, cabe buscar o entendimento mais profundo do significado do termo "responsável", às vezes usado no turismo sem o cuidado da reflexão, seja por conta de certos modismos, seja para designar alguma prática correlata, mas que não se configura em TR necessariamente. Para isso, é preciso desvelar os significados da responsabilidade e os conceitos que se apresentam entrelaçados a ela, para posteriormente ser capaz de deixar mais claro os princípios e fundamentos do Turismo Responsável. Busca-se nesse capítulo a compreensão do principal conceito constitutivo da ideia de Turismo Responsável, o da responsabilidade, aqui tomado como um valor ético e moral e relacionado à ideia de respeito.

\subsection{RESPONSABILIDADE: ORIGEM E SIGNIFICADOS}

Segundo o Dicionário da Filosofia (ABBAGNANO, 2012, p.1009), a palavra responsabilidade significa a "possibilidade de prever os efeitos do próprio comportamento e de corrigi-lo com base em tal previsão". Na linguagem comum, chamase alguém de "responsável" ou se elogia seu "senso de responsabilidade" quando se pretende dizer que a pessoa em questão inclui nos motivos de seu comportamento a previsão dos possíveis efeitos dele decorrentes.

Abbagnano (2012) ressalta que alguns teóricos afirmam que responsabilidade é diferente de imputabilidade, palavra esta que significa a atribuição de uma ação a um agente, considerado seu causador.

Corroborando com essa ideia, podemos citar Platão e Wolf. O primeiro aludia à noção de imputabilidade quando assegurava que, a propósito da escolha que as almas fazem de seu próprio destino, "cada qual é a causa de sua própria escolha, ela não pode ser imputada à divindade" (Rep, X, 617 e; cf. Tim, $42 \mathrm{~d}$, apud Abbagnano, 2012). E o segundo definia a imputação como "o juízo em virtude do qual o agente é declarado causa livre daquilo que se segue a sua ação, ou seja, do bem e do mal que dela decorrem para ele mesmo ou para os outros" (Philosofia practica, I, parag. 527, apud Abbagnano, 2012).

Essa definição era puramente iterada por Kant: "a imputação no significado moral é o juízo em virtude do qual alguém é considerado autor (causa livre) de uma ação que está submetida a leis e se chama fato." (Met. Der Sitten, I, Intr., IV, apud 
Abbagnano, 2012). Dessa forma, observa-se que a imputabilidade, assim entendida, é um conceito diferente do de responsabilidade, pois este, como vimos, possui relação com a prevenção dos efeitos negativos dos atos de um sujeito por ele próprio.

Todavia, apesar dessa diferença ser destacada por alguns filósofos, ao se buscar o conceito de responsabilidade no "Stanford Encyclopedia of Philosophy" encontra-se sua associação com o estudo sobre a "responsabilidade moral" na qual existe uma ideia de imputabilidade associada ao tema. Pois sua explicação segue da seguinte forma:

Quando uma pessoa realiza ou deixa de realizar uma ação moralmente significativa, às vezes pensamos que um determinado tipo de resposta é garantido. Louvor e culpa são, talvez, as formas mais óbvias que esta reação pode tomar. Por exemplo, alguém que encontra um acidente de carro pode ser considerado digno de louvor por ter salvo uma criança de dentro do carro em chamas, ou, alternativamente, pode ser considerado como digno de culpa por não ter usado o telefone celular para ligar pedindo ajuda. Para considerar tais agentes como digno de uma dessas reações é preciso considerá-los como responsáveis por aquilo que eles têm feito ou deixado de fazer (Estes são exemplos de outros dirigindo atribuições de responsabilidade. A reação também pode ser autodirigida, por exemplo, pode-se reconhecer a si mesmo para ser censurável). Assim, para ser moralmente responsável por algo, digamos, uma ação, é ser digno de um tipo particular de reação-elogio, culpa, ou algo parecido, por ter realizado isso (Stanford Encyclopedia of Philosophy, tradução nossa).

Aprofundando nesse conceito verifica-se que a reflexão filosófica sobre a responsabilidade moral tem toda uma história a ser descrita. Uma das razões apresentadas para esse interesse persistente é o modo como o tema aparece conectado com a nossa concepção de nós mesmos como "pessoas". Muitos filósofos têm sustentado que uma característica distinta das pessoas é o seu estatuto como agentes moralmente responsáveis, um estado de descanso, alguns propuseram um tipo especial de controle que só eles podem exercer. Muitos que querem ver as pessoas desta forma quiseram saber se o seu estatuto especial é ameaçado e se certas outras reivindicações sobre o nosso universo são verdadeiras ${ }^{25}$.

Ao nos remetermos à epistemologia da palavra "responsabilidade" constata-se que é um substantivo, derivado da palavra "responder", originado do verbo latino respondĕo, des, ère, que significa produzir efeito, satisfazer, justificar, pagar, comprometer-se da sua parte, e prometer, entre outras acepções, como é indicado pelos

\footnotetext{
${ }^{24}$ Disponível em https://plato.standford.edu/index.html

${ }^{25}$ Ver mais em http://plato.stanford.edu/entries/moral-responsibility/
} 
dicionários latinos. O verbo "responder" é formado pelos étimos latinos "re" - que sugere movimento reverso, retorno a uma situação prévia, reforço ou intensificação de alguma ação - e "spondiō", "dēre", que significa esperança, expectativa, promessa, declaração solene, palavra dada a alguém, garantia ou incumbência ${ }^{26}$ (BARBIERI; CAJAZEIRA, 2009, p.1). Assim, de acordo com a origem da palavra, é possível perceber o valor expressivo que ela carrega e entender que um sujeito responsável pode ser percebido como um indivíduo que se compromete em fazer a sua parte, dentre outras denotações.

Embora a procedência latina e sua relevante utilização desde a Roma Antiga, o seu significado moderno somente apareceu no século XVIII, em textos que tratam de política e relacionado ao papel dos governos em sociedades democráticas, mais precisamente tratando-se do controle da comunidade sobre seus governantes em sociedades regidas por constituições elaboradas democraticamente. Segundo Abbagnano (2012), esse conceito de responsabilidade relacionado com os governantes nas sociedades democráticas surgiu pela primeira vez em 1787, no livro The federalist, de Alexandre Hamilton, considerado um dos líderes da independência dos Estados Unidos. Assim, o primeiro significado do termo na modernidade foi político, em expressões como "governo responsável" ou "responsabilidade do governo", indicativas do caráter do governo constitucional que age sob o controle dos cidadãos e em função desse controle (ABBAGNANO, 2012).

De acordo com Abbagnano (2012), no campo da Filosofia, o termo foi usado nas controvérsias sobre a liberdade e acabou sendo útil principalmente aos empiristas ingleses, que quiseram mostrar a incompatibilidade do juízo moral com a liberdade e as necessidades absolutas. $\mathrm{Na}$ verdade, este autor evidencia que a noção de responsabilidade baseia-se na de escolha, e esta é essencial ao conceito de liberdade limitada.

Nesse sentido, pode-se recorrer a Kant (2005), o qual também relaciona a responsabilidade com a condição da liberdade. Acrescenta, porém, outros requisitos ao conceito de responsabilidade. Para o filósofo, ela está relacionada a três condições, que são: o livre arbítrio/a liberdade, a motivação interna e a consciência da conduta moral interpessoal, conforme a Figura 04 ilustrada abaixo.

${ }^{26}$ GLARE, P.G. Oxford Latin Dictionary. Oxford: Claredon Press, 1982. 


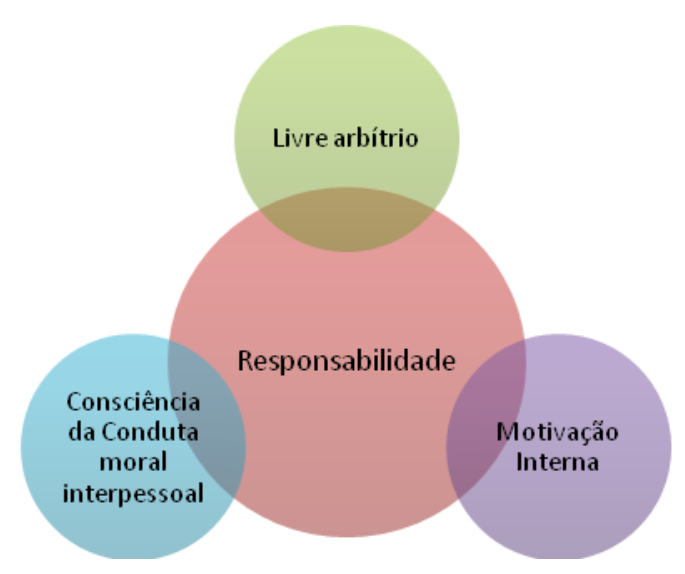

Figura 04 - Três condições da Responsabilidade Fonte: Adaptado de Kant (2005).

A liberdade seria o ponto chave para a explicação da autonomia da vontade. A vontade seria um tipo de causalidade dos seres humanos dotada de razão e a liberdade seria esta propriedade que possui poder causal para agir independentemente da determinação de causas externas. Vale destacar que para Kant (2005), o exercício pessoal da liberdade demanda responsabilidade.

Conforme esse pensador, a segunda condição para a responsabilidade seria a motivação interna, que pode ser entendida como a capacidade dos seres humanos raciocinarem e agirem de acordo com suas próprias habilidades, livres de compulsão externa. E a terceira condição seria a consciência da existência de um padrão definido de moral interpessoal pelo qual todos os agentes responsáveis são responsabilizados.

Com a união dessas três condições, segundo Kant, "a responsabilidade será a razão prática da liberdade" (MENESES; REIS, 2009, p.109).

Barbieri e Cajazeira (2009, p.2) complementam essa ideia ao explicar que a responsabilidade de um sujeito refere-se à "obrigação de responder pelas consequências previsíveis das suas ações em virtude de leis, contratos, normas de grupos sociais ou de sua convicção íntima". A competência de escolher de forma livre as opções de uma ação é uma condição básica para a origem da responsabilidade de um sujeito.

A ideia de capacidade de escolha de maneira livre ser um requisito fundamental à origem da responsabilidade, também é um assunto tratado por Aristóteles. Ao construir 
uma teoria da responsabilidade moral $^{27}$, ele esclarece que apenas certo tipo de agente qualifica-se como um agente moral e, portanto, devidamente sujeito a atribuições de responsabilidade, é aquele que possui a capacidade de decisão. Para Aristóteles, a decisão é um tipo particular de desejo resultante da deliberação, que expressa a concepção do agente do que é bom. Aristóteles também se dedica a desvelar as condições em que devem estar um agente moral, censurável ou louvável, para alguma ação específica ou característica de perfil. Sua proposta geral é de que é um candidato apto para o elogio ou a culpa, se e somente se, a ação e/ou a disposição seja voluntária. Segundo Aristóteles, uma ação ou característica voluntária tem dois atributos distintos. Em primeiro lugar, existe uma condição de controle: a ação ou característica devem ter origem no agente. Ou seja, ele deve ser o agente para executar essa ação ou possuir o traço de caráter se ele não puder ser compelido externamente. Em segundo lugar, Aristóteles propõe uma condição epistêmica: o agente deve estar ciente do que é que está a fazer ou trazer (Aristóteles, apud Stanford Encyclopedia of Philosophy). ${ }^{28}$

Logo, as condições para ser um "agente moral", segundo Aristóteles, podem ser observadas de forma esquemática (Figura 05) a seguir:
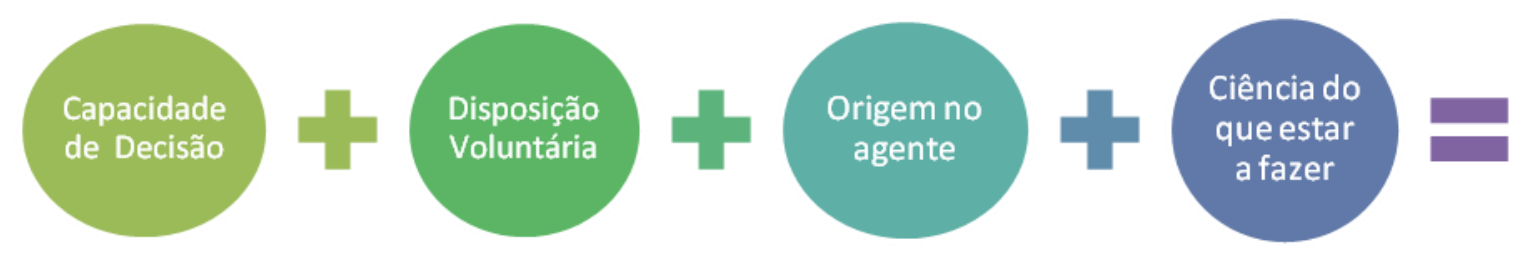

Agente

Moral

Figura 05 - Condições para ser um agente moral

Fonte: Adaptado de Aristóteles apud Stanford Encyclopedia of Philosophy.

Conforme Amartya Sen (2000, p. 322), "as liberdades substantivas que desfrutamos para exercer nossas responsabilidades são extremamente dependentes das circunstâncias pessoais, sociais e ambientais." Por exemplo, se o indivíduo for privado de bem-estar, ele também foi privado de levar uma vida responsável, pois esta

\footnotetext{
${ }^{27}$ Como apresentado no Stanford Encyclopedia of Philosophy, Aristóteles parece ter sido o primeiro a construir uma teoria da responsabilidade moral. No curso de discutir as virtudes humanas e seus vícios correspondentes, Aristóteles faz uma pausa em "Ética a Nicômaco" (III. 1 - 5) para explorar suas bases. Ele começa com uma breve exposição do conceito de responsabilidade moral, que às vezes é apropriado para responder a um agente com louvor ou culpa, com base em suas ações e/ou traços de caráter disposicionais (1109b $30-35)$.

${ }^{28}$ Disponível em http://plato.stanford.edu.
} 
depende do gozo de certas liberdades básicas. Dessa forma, a autora afirma que "responsabilidade requer liberdade". Do mesmo modo, o argumento do apoio social para ampliar a liberdade das pessoas pode ser considerado um assunto favorável à responsabilidade individual, e não contra. E ainda completa que o percurso entre a liberdade e a responsabilidade é de "mão dupla". De maneira que com a isenção da liberdade substantiva e da capacidade para realizar alguma coisa, o indivíduo também se isenta da responsabilidade de realizá-la. No entanto, a liberdade e a capacidade efetivas para se realizar algo atribui ao sujeito o dever de refletir sobre fazê-la ou não, e isso envolve responsabilidade individual. Nesse sentido, a liberdade é necessária e suficiente para a responsabilidade.

Seja em meio às discussões filosóficas, seja no âmbito político, os conceitos de liberdade individual e coletiva sempre andaram lado a lado com a definição de responsabilidade $e$, neste sentido, sempre perpassaram o campo da política na configuração dos deveres de cidadãos e governos. Dessa forma, para Amartya Sen (2000) a responsabilidade é papel a ser assumido por todas as instâncias da sociedade, passando pelo Estado, indivíduos, organizações sociais e mídia, chegando às instituições privadas e de regulação do mercado, como pode ser visto no seguinte trecho:

[...] O comprometimento social com a liberdade individual obviamente não precisa atuar apenas por meio do Estado: deve envolver também outras instituições: organizações políticas e sociais, disposições de bases comunitárias, instituições não-governamentais de vários tipos, a mídia e outros meios de comunicação e entendimento público, bem como as instituições que permitem o funcionamento de mercados e relações contratuais. A visão arbitrariamente restrita de responsabilidade individual - com o indivíduo posto em uma ilha imaginária, sem ser ajudado nem estorvado por outros - tem de ser ampliada, reconhecendo-se não meramente o papel do Estado, mas também as funções de outras instituições e agentes (SEN, 2000, p. 322-323).

Já a ética da responsabilidade corresponde ao "agir racional em relação ao fim" e é típica de quem se preocupa tanto com os meios capazes de levar a obter determinados fins, quanto com os efeitos ligados à própria ação (ABBAGNANO, 2012). Uma forma mais sui generis de ética da responsabilidade é também a teoria de Lévinas, que, antepondo a noção de responsabilidade à de amor (considera "suspeita" demais), faz a primeira coincidir com a absoluta dedicação ao próximo, fazer alguma coisa pelo outro e se doar. A responsabilidade é aquilo que me incumbe de modo exclusivo e que, 
humanamente, não posso rejeitar. "Esse peso é a suprema dignidade do único." (ABBAGNANO, 2012) Nesse sentido, Dostoievski diz que "somos todos responsáveis por tudo e por todos, diante de todos, e eu mais que todos os outros".

Hans Jonas, em 1979, fala de "Princípio da Responsabilidade" e insiste no novo imperativo ecológico da salvaguarda das gerações futuras. "Age de tal modo que as consequências da tua ação sejam compatíveis com a permanência de uma vida humana autêntica na terra." (JONAS, 1979 apud ABBAGNANO, 2012). Jonas acaba por elevar a figura do homem à de "guardião do ser". Ele é o primeiro a indicar o princípio ecológico da responsabilidade para com as gerações futuras e toda a biosfera (O Princípio da Responsabilidade, 1979 apud ABBAGNANO, 2012).

Em meio aos diferentes conceitos de "responsabilidade" pesquisados para o presente trabalho, aqueles propostos por Alexander, Goodwin e Robinson ${ }^{29}$ afiguram-se essenciais para o entendimento do que é Turismo Responsável, já que os significados que eles adotam destacam a importância da inclusão da responsabilidade em todos os agentes envolvidos no turismo, seja pelas consequências de ações ou omissões, seja pela capacidade de resposta, como esclarecemos a seguir.

De acordo com esses autores, há duas maneiras de se pensar sobre o significado da responsabilidade. Elas são interdependentes, porém, significativamente diferentes. De um lado, pode-se pensar a responsabilidade no sentido de "prestação de contas" e, por outro, há o sentido de "capacidade de responder ou reagir".

A primeira noção relaciona-se com ações e consequências que podem ser atribuídas a pessoas físicas ou jurídicas, passíveis de serem juridicamente responsabilizadas. A conscientização desses atores acerca da possibilidade de que venham a ser responsabilizados pelas consequências de suas ações ou omissões é o que os sensibiliza e os motiva a agirem de maneira responsável. Essa responsabilidade pode ser dada em um sentido legal estrito e imposta por estruturas legais ou códigos profissionais (ALEXANDER; GOODWIN; ROBINSON ${ }^{30}$ ).

No segundo sentido, indivíduos e organizações são esperados a responder e a fazer a diferença. Isso requer parcerias, uma pluralidade de relações, aprendizagem, prática e reflexão crítica. Pessoas que exercitam a capacidade de resposta ou reação possuem empatia e um forte sentido de reconhecimento do "outro". Elas reconhecem a

\footnotetext{
${ }^{29}$ Disponível em http://www.responsibility.org.uk/. Acesso em 12 de maio de 2014.

${ }^{30}$ Idem.
} 
interdependência e a responsabilidade que flui a partir daí. Elas têm o ímpeto de responsabilidade, possuem ou buscam papéis nos quais elas possam exercer agência. Elas exigem - o que Aristóteles chamou de "phronesis" - a capacidade de determinar as extremidades e de agir em contextos particulares. Isso demanda prudência e certo grau de maturidade (ALEXANDER; GOODWIN; ROBINSON ${ }^{31}$ ).

Ao seguir esse pensamento sobre reconhecimento do "outro", Harold Goodwin $\left(2014\right.$, informação verbal) ${ }^{32}$ acrescenta que a responsabilidade está diretamente ligada à ideia de respeito. Corroborando com essa ideia, Abbagnano (2012) explica que respeito é o "reconhecimento da dignidade ${ }^{33}$ própria ou alheia e o comportamento inspirado nesse reconhecimento". Sendo assim, pode-se associar o respeito à responsabilidade, pois na medida em que a dignidade do outro é reconhecida isso gera um comportamento racionalizado, o sujeito irá agir com responsabilidade para que o outro seja respeitado.

O "respeito" pode ser relacionado com a ética, assim como a "responsabilidade". Agir, tanto com respeito quanto com responsabilidade, significa atuar eticamente. Nesse assunto, podemos citar Demócrito (apud Abbagnano, 2012), pois ele foi o primeiro a transformar o respeito em princípio da ética. Ele fornece a seguinte explicação:

Não deves ter para com os outros homens mais respeito que para contigo mesmo, nem agir mal quando ninguém o saiba mais do que quando todos o saibam; deves ter para contigo o máximo respeito e impor à tua alma a seguinte lei: não fazer o que não se deve fazer (Fr. 264, Diels, apud ABBAGNANO, 2012)

Ainda nesse tema, recorremos à Platão, que em Protágoras, narra a explicação mitológica do filósofo sofista para o surgimento do respeito entre os homens. Protágoras explica que o respeito é um dos princípios necessários para que a humanidade tenha condições de se perpetuar: "temendo que nossa estirpe se extinguisse, Zeus ordenou que Hermes trouxesse o respeito recíproco e a justiça para o meio dos homens, a fim de que esses fossem princípios ordenadores das cidades, criando entre os cidadãos vínculos de benevolência" (Prot. 322e, apud ABBAGNANO, 2012). Dessa forma,

\footnotetext{
${ }^{31}$ Disponível em http://www.responsibility.org.uk/. Acesso em 12 de maio de 2014.

32 Informação fornecida por Goodwin em entrevista com a pesquisadora em Brasília / Brasil, em 29 de abril de 2014.

33 "“...] todo o homem, aliás, todo ser racional, como fim em si mesmo, possui um valor não relativo (como é por ex. um preço), mas intrínseco, ou seja, a dignidade. 'O que tem preço pode ser substituído por alguma outra coisa equivalente; o que é superior a qualquer preço, e por isso não permite nenhuma equivalência, tem dignidade". (ABBAGNANO, 2012, p. 326).
} 
respeito recíproco e justiça são os dois elementos fundamentais da "arte política", que é a técnica de vida em comunidade.

Aristóteles, todavia, compreendeu o respeito entre as emoções, excluindo-o das virtudes, opondo-o e o opôs ao temor (ABBAGNANO, 2012). Kant igualmente o restringiu à esfera das emoções. Ele ponderou ser o respeito sentimento sui generis, moral e não patológico: "é produzido apenas pela razão. Não serve ao juízo das ações nem como fundamento da lei moral objetiva, mas simplesmente como móbil para transformar essa lei em máxima”.

Ainda segundo Abbagnano (2012), o respeito é próprio das pessoas, não das coisas, pois implica uso da razão, sendo a ação negativa da razão sobre a sensibilidade, portanto a própria sensibilidade. Mesmo fora da filosofia a noção de respeito foi fortemente influenciada por essas observações de Kant. Por respeito entende-se comumente o "empenho em reconhecer nos outros homens ou em si mesmo, uma dignidade que se tem o dever de salvaguardar" (ABBAGNANO, 2012, p.1008 e 1009).

Visto isso, um quadro-resumo sobre responsabilidade foi feito, englobando sete conceitos apresentados anteriormente nesta pesquisa, e será apresentado a seguir no Quadro 01, com o intuito de melhor visualização e entendimento do termo.

Quadro 01 - Conceitos de Responsabilidade

\begin{tabular}{|l|l|}
\hline \multicolumn{1}{|c|}{ FONTE } & \multicolumn{1}{|c|}{ CONCEITOS } \\
\hline DICIONÁRIO DA FILOSOFIA (2012, p.1009). & $\begin{array}{l}\text { "Possibilidade de prever os efeitos do próprio } \\
\text { comportamento e de corrigi-lo com base em } \\
\text { tal previsão" }\end{array}$ \\
\hline ABBAGNANO (2012). & $\begin{array}{l}\text { Noção de responsabilidade baseia-se na de } \\
\text { escolha, e esta é essencial ao conceito de } \\
\text { liberdade limitada. }\end{array}$ \\
\hline KANT (2005). & $\begin{array}{l}\text { Relacionada a três condições: o livre } \\
\text { arbítrio/a liberdade, a motivação interna e a } \\
\text { consciência da conduta moral interpessoal. }\end{array}$ \\
\hline BARBIERI; CAJAZEIRA (2009, p.2). & $\begin{array}{l}\text { "Obrigação de responder pelas } \\
\text { consequências previsíveis das suas ações } \\
\text { em virtude de leis, contratos, normas de } \\
\text { grupos sociais ou de sua convicção íntima". }\end{array}$ \\
\hline JONAS (1979). & $\begin{array}{l}\text { Princípio da Responsabilidade: agir de tal } \\
\text { modo que as consequências da sua ação } \\
\text { sejam compatíveis com a permanência de } \\
\text { uma vida humana autêntica na Terra. }\end{array}$ \\
\hline $\begin{array}{l}\text { ALEXANDER; GOODWIN; ROBINSON } \\
\text { (Disponível } \\
\text { http://www.responsibility.org.uk/). }\end{array}$ & $\begin{array}{l}\text { "Prestação de contas": a conscientização do } \\
\text { sujeito acerca da possibilidade de que venha } \\
\text { a ser responsabilizado pelas consequências } \\
\text { de suas ações ou omissões é o que o } \\
\text { sensibiliza e o motiva a agir de maneira } \\
\text { responsável. }\end{array}$ \\
\hline
\end{tabular}




\begin{tabular}{|l|l|}
\hline \multicolumn{1}{|c|}{ FONTE } & \multicolumn{1}{|c|}{ CONCEITOS } \\
\hline $\begin{array}{l}\text { ALEXANDER; GOODWIN; ROBINSON } \\
\text { (Disponível } \\
\text { http://www.responsibility.org.uk/). }\end{array}$ & $\begin{array}{l}\text { "Capacidade de responder ou reagir": } \\
\text { Pessoas que exercitam a capacidade de } \\
\text { resposta ou reação possuem empatia e um } \\
\text { forte sentido de reconhecimento do "outro". } \\
\text { Elas reconhecem a interdependência e a } \\
\text { responsabilidade que flui a partir daí. }\end{array}$ \\
\hline GOODWIN (2014). & $\begin{array}{l}\text { Relacionada à ideia de respeito } \\
\text { (reconhecimento da dignidade própria ou } \\
\text { alheia e o comportamento inspirado nesse } \\
\text { reconhecimento). }\end{array}$ \\
\hline
\end{tabular}

Fonte: quadro elaborado pela autora, a partir de ABBAGNANO (2012); ALEXANDER; GOODWIN; ROBINSON; BARBIERI e CAJAZEIRA (2009); DICIONÁRIO DA FILOSOFIA (2012); GOODWIN (2014); JONAS (1979); KANT (2005).

Diante das explicações apresentadas e do quadro-resumo exibido anteriormente, foi possível entender a origem da responsabilidade e seus diversos significados. Além disso, evidenciou-se que há uma relação entre responsabilidade, respeito e ética. Dessa forma, é importante entender, também, o significado de ética, já que para nós a responsabilidade teria relação com valores éticos e morais. Far-se-á uma breve explicação desse tema em seguida para que essa analogia seja compreendida de forma mais clara.

Por efeito disso, nesse trabalho, partiu-se da compreensão da responsabilidade como sendo um tipo de valor. Para entender melhor o conceito de valor, será levada em consideração a existência de dois mundos distintos - o mundo das coisas e o dos valores. Segundo Scheler (2001, apud CADENA, 2013), da mesma forma que as coisas trazem suas essências, as quais determinam o que tais coisas são, elas são igualmente portadoras de valores. A diferença está no fato de que a essência é uma qualidade ou característica que define a coisa, sendo assim seu núcleo invariante. Todavia, o valor é aplicado aos objetos, o objeto suporta o valor, ou, até mesmo, o objeto é acompanhado pelo valor. Esses objetos são chamados de bens. Os sujeitos apreendem esses valores que, por sua vez, acendem um estado sentimental de prazer ou desprazer. Assim, esses estados sentimentais se relacionam às qualidades do agradável e desagradável.

Ainda de acordo com Scheler (2001, apud CADENA, 2013), o sentimento é o órgão dos valores. É no momento da vivência, quando preferimos, postergamos, amamos ou odiamos algo, que os valores e as conexões entre eles são percebidos pela 
intuição emocional. Ou seja, Scheler acredita que os valores fogem à ordem da razão e são inerentes ao espírito, mais especificamente à "zona emocional do espírito".

Aranha e Martins (2007, p.198) explicam que os valores não são da mesma maneira que as coisas são, já que o valor é sempre uma relação entre o sujeito que valora e o objeto que é valorado. Dessa forma, não existe "valor em si", mas sim "valor para alguém". ${ }^{34}$

De maneira geral, ao buscarmos o significado de valor na Filosofia, verificamos que os filósofos o definem como "o que deve ser objeto de referência ou de escolha" ou, mesmo, "um valor é o que vale; e valer é ser desejável ou desejado" (ARANHA; MARTINS, 2007, p.199).

Mesmo sem ter consciência do ato, estamos sempre avaliando. Para fazer escolhas, é preciso avaliar ${ }^{35}$, que quer dizer identificar, reconhecer e apreciar o valor. A forma de se viver está diretamente ligada às nossas escolhas. Portanto, podemos afirmar que "valorar é uma experiência fundamentalmente humana que se encontra no centro de toda escolha da vida" (ARANHA; MARTINS, 2007 p.198) Como afirmam Aranha e Martins (2007, p.198), "o objetivo de qualquer valoração, é sem dúvida, orientar a prática". A partir do momento que valoramos algo e verificamos ser essencial, tomamos atitudes positivas em relação a isso. Por exemplo, se o ar é um valor para o ser vivo, é preciso evitar a poluição, que compromete a qualidade desse bem indispensável. Se a confiabilidade é um valor, não se deve mentir; caso contrário, as relações humanas são abaladas. Logo, perante aquilo que é, a valoração nos norteia para o que deve ser.

Visto isso, para entender a responsabilidade como um valor ético, é necessário entender o significado deste conceito. Porém, ao se buscar a acepção desse termo, percebe-se que os conceitos de ética e moral estão interligados, o que nos faz explicitar ambas as considerações.

Primeiramente, verificou-se que, segundo Aurélio (2009), ética seria o "estudo dos juízos de apreciação que se referem à conduta humana suscetível de qualificação do ponto de vista do bem e do mal".

\footnotetext{
${ }^{34}$ Esse conceito está dentro de uma perspectiva materialista, contrária à teoria idealista. Essas duas abordagens serão explicadas ainda neste item.

${ }^{35}$ Segundo Michaelis Moderno Dicionário da Língua Portuguesa (POLITO, A.G., 2004), "avaliar" significa: Calcular ou determinar o valor, o preço ou o merecimento de. Reconhecer a grandeza, a intensidade, a força de. Apreciar: Avaliar a força, os costumes. Computar, orçar.
} 
Em seguida, foi verificado o conceito de acordo com Rios (1999):

Os papeis sociais têm seu fundamento no "ethos" (jeito de ser) de uma sociedade. É importante fazer aqui algumas distinções que permitirão compreender melhor os conceitos com os quais estamos lidando. É necessário distinguir ethos e ética, ética e moral. No cotidiano os conceitos de ética e moral se confundem ou se identificam. (...) Mas, se recorrermos à origem etimológica das palavras, vamos encontrar os vocábulos ethos (grego) e mores (latino) ambos significam costume, jeito de ser. O domínio do ethos é o da moralidade, do estabelecimento de deveres a partir da reiteração das ações e da significação a elas atribuída (RIOS, 1999, p. 21).

Prendemo-nos, ainda, aos ensinamentos de Vasquez (1977) para quem a moral seria:

[...] como um conjunto de normas e regras destinadas a regular as ações dos indivíduos numa comunidade social dada. E a ética é uma reflexão crítica, um estudo sobre a dimensão moral do comportamento do homem. Cabe a ela, enquanto investigação que se dá no interior da filosofia procurar ver claramente os valores, problematizá-los buscar sua consciência. É nesse sentido que ela não se confunde com a moral. As proposições da ética devem ter o mesmo rigor, a mesma coerência e fundamentação das proposições científicas. Ao contrário, os princípios, as normas ou os juízos de uma moral determinada não apresentam esse caráter. Não existe uma moral científica. [...] A moral não é ciência, mas objeto da ciência, e, neste sentido é por ela investigada e estudada. A ética não é a moral; sua missão é fundamentar e explicar a moral, efetiva [...] sem ser em si mesma normativa ou prescritiva (VASQUEZ,1977. p. 19).

Dessa forma, verificou-se que a moral pode ser vista como um conjunto de valores e de regras de comportamento que as coletividades, sejam elas nações, grupos sociais ou organizações, adotam por julgarem corretos e desejáveis (SROUR, 2000 apud ASHELEY, 2005, p.5). Ela abrange as representações imaginárias que dizem aos agentes sociais o que se espera deles, quais comportamentos são bem-vindos, qual é a melhor maneira de agir coletivamente, o que é o bem e o que é o mal, o permitido e o proibido, o certo e o errado, a virtude e o vício. Já a ética é mais sistematizada e corresponde a uma teoria de ação rigidamente estabelecida. A moral, em contrapartida, é concebida menos rigidamente, podendo variar de acordo com o país, o grupo social, a organização ou mesmo o indivíduo em questão.

Em outras palavras, os valores morais de um grupo ou organização definem o que é ser ético para si e, a partir daí, elaboram-se rígidos códigos de ética que precisam ser seguidos sob pena de ferirem os valores morais pré-estabelecidos. 
Conclui-se desta forma, que a moral indica o comportamento que deve ser considerado certo ou errado. E a ética relaciona-se com o fundamento do valor que orienta este comportamento. Ética é a ciência do comportamento moral dos homens em sociedade. É, portanto, uma ciência já que tem objeto próprio, leis próprias e método próprio. Seu objeto é a moral, um dos aspectos do comportamento humano.

Com esta conceituação, tem-se que a ética não se confunde com a moral. As duas se referem aos costumes ${ }^{36}$, a ética de uma forma mais abrangente, uma vez que é uma ciência e a moral apenas objeto da ciência. A ética mostra às pessoas os valores e os princípios que devem nortear sua existência, faz com que elas desenvolvam um sentido moral e influencia em suas condutas, extraindo dos fatos morais os princípios a eles aplicáveis.

As questões éticas são percebidas no cotidiano de todos. Tais questões se relacionam com várias áreas, no ambiente de trabalho, na escola, nas relações familiares e de amizade, na religião e tantas outras que dizem respeito ao ser humano.

Álvaro Valls (1986, p.10), também reflete sobre o assunto e levanta um aspecto da ética que nos parece fundamental:

Os costumes mudam e o que ontem era considerado errado hoje pode ser aceito, assim como o que é aceito pelos índios do Xingu pode até ser rejeitado em outros lugares do mesmo país. A ética não seria então uma simples listagem das convenções sociais provisórias? (VALLS, 1986. p. 10).

Destas considerações surgem novos apontamentos. A ética seria apenas um comportamento adequado aos costumes vigentes. Aquele que se comporta de forma discordante, divergindo dos costumes aceitos, estaria no erro, enquanto a sociedade não adotar o comportamento diferente. A ética não apenas reflete os costumes vigentes, que variam constantemente, por isso ela deve ser vistas e fundamentada em princípios mais universais.

É nesse sentido que se pode dizer que a responsabilidade teria relação com a ética, pois após contextualizarmos a importância que a responsabilidade tem nos dias atuais, os quais são envolvidos com as preocupações com a sustentabilidade, é permitido fazer uma analogia entre responsabilidade e ética, pois a primeira seria o comportamento adequado aos costumes atuais, então ela se enquadraria à segunda.

\footnotetext{
${ }^{36}$ Ethos, em grego e no latim, significa costumes.
} 
Immanuel Kant $^{37}$ (1724-1804), ao contrário dos filósofos clássicos que defendiam que os valores se fundamentavam na metafísica - sendo, assim, como já explicado, universais e absolutos, existentes em si, independente do sujeito que avalia -, afirma que cabe ao sujeito ${ }^{38}$ assumir o peso e a responsabilidade dos seus valores. Destarte, a filosofia Kantiana forneceu subsídios às discussões axiológicas contemporâneas, as quais deram destaque à noção de temporalidade e de vir-a-ser: "neste mundo em mudança, que está sempre 'por se fazer', os valores adquirem dimensão própria" (ARANHA; MARTINS, 2007 p. 203).

Corroborando com este pensamento, Nietzsche ${ }^{39}$ quebra antigas crenças ao questionar a escala de valores aceita, muitas vezes, devido ao hábito e, sobretudo, imposta pela tradição cristã. Ele propõe a "transvalorização dos valores", que permite investigar sobre o "valor dos valores" e explicita que os valores são humanos, não existiram desde sempre e, por conseguinte, foram instituídos (ARANHA; MARTINS, 2007 p. 203).

Pode-se, então, pensar em distintos "tipos" de valores, nas mais diversas esferas da vivência humana e da sociedade. Segundo Max Scheler (2001, apud CADENA, 2013), por exemplo, os valores são objetivos e dispostos em "ordem eterna", o que torna possível hierarquizá-los. Assim, juízo (faculdade de julgar, de avaliar, faculdade de pensar o particular como inserido no geral), é, então, "um julgamento crítico sobre as escolhas humanas, uma reflexão propositiva das relações existentes entre meios e fins de nossa ação no mundo".

Já para Werneck, os valores éticos têm raízes no senso de moral e justiça do ser humano, e, ainda, nos conceitos de bem e mal, relacionando-se sempre à moralidade. Ele afirma que "os valores éticos correspondem à carência humana pelo bem moral. Ao seu anseio por respeito e justiça. Por liberdade, lealdade, honestidade, responsabilidade

\footnotetext{
${ }^{37}$ Principal representante do lluminismo alemão. Foi um dos mais influentes pensadores da ética no período moderno. Sua proposição de uma ética de princípios e seu racionalismo encontram importantes seguidores no pensamento contemporâneo, que neste campo, se desenvolveu em grande medida a partir da influência da sua obra. Ele se preocupou com questões morais concretas e com a aplicação prática dos princípios éticos (MARCONDES, 2007, p.86).

38Nesse caso, Kant não se referia a um sujeito individual, mas sim ao sujeito universal, que ele chama de sujeito transcendente capaz de autonomia, de julgar por si próprio ao fazer juízos estéticos e morais.

39Friedrich Nietzsche, filósofo alemão, filho de um pastor luterano e bastante marcado pelo rigor da religião protestante, foi um dos críticos mais mordazes da moral tradicional desde a filosofia grega até o cristianismo. Pensador radical, ele propõe uma "transvalorização de todos os valores", visando romper não só com a moral judaico-cristã, mas também com a tradição grega de Sócrates, representativa do racionalismo e da visão unilateral que teria prevalecido em toda a cultura ocidental (MARCONDES, 2007, p.101).
} 
e por todos os demais valores decorrentes do princípio da moralidade que exige que se faça o bem e evite o mal (WERNECK, 2010).

Segundo Veloso (2005, p.5, apud Asheley, 2005), valores morais correspondem a "crenças pessoais sobre comportamento eticamente correto ou incorreto, tanto por parte do próprio indivíduo quanto com relação aos outros". Assim, valores morais e ética se complementam.

Nesse sentido, Carrol (2000, p.36 apud ASHELEY, 2005, p.5) afirma que responsabilidades éticas não são codificadas em leis e elas dizem respeito a atividades, práticas, políticas e comportamentos esperados (no sentido positivo) ou proibidos (no sentido negativo) por membros da sociedade, obedecem a valores morais específicos. Para Srour (2000, apud ASHELEY, 2005), valores morais são crenças pessoais sobre comportamento eticamente adequado ou inadequado, por parte do próprio indivíduo ou até mesmo com relações aos outros. É dessa maneira que o autor corrobora que valores morais e ética se completam.

Compreender a essência do valor ético e moral da responsabilidade é, portanto, fundamental para o entendimento e a aplicação do conceito de Turismo Responsável, matéria que será tratada nos próximos capítulos.

Antes de adentrar no conceito de Turismo Responsável, é válido ressaltar que a responsabilidade ao começar a ter o reconhecimento de sua importância na sociedade começa a refletir na conduta das organizações. Com isso, surge a ideia de responsabilidade social nas empresas, assunto que será abordado berevemente no próximo tópico.

\subsection{A RESPONSABILIDADE NAS ORGANIZAÇÕES}

As pressões sociais e econômicas criadas pela globalização atingiram o mundo dos negócios. A pressão que um mercado globalizado desempenha nas empresas demanda sua contínua autoanálise. Como consequência, surge um novo ethos que rege o modo como os negócios são realizados em todo o mundo. Logo, o papel das empresas e até mesmo do próprio Estado está passando por mudanças. Há uma tendência da função da empresa na sociedade ficar cada vez mais ampla e complexa, e em contrapartida, a possibilidade de vários papéis tradicionais do Estado entrarem em ameaça (ZADEK, 1998, p.1424 apud ASHLEY, 2005, p.7). 
No contexto atual, de grandes transformações, a ética afeta não só os lucros e a credibilidade das organizações, como também a sobrevivência da economia global. Logo, é nesse cenário que a responsabilidade social corporativa se fortaleça e se torne a melhor característica que define esse novo ethos (COSTA, 1998, apud ASHLEY, 2005).

Carrol (1998, p. 1231-1261, apud ASHELEY, 2005) afirma que as organizações precisam aprender a equacionar a necessidade de obter lucros, obedecer às leis, ter um comportamento ético e envolver-se em alguma forma de filantropia para com as comunidades em que se inserem. Além disso, mudanças, como nas formas que são concebidos e comercializados os produtos e serviços, trazem consigo novas questões éticas com que as organizações têm de aprender a lidar - principalmente porque, cada vez mais, as novas tecnologias de informação e oportunidades comerciais e empresariais abertas pela globalização tendem a levar todas as organizações a abraçar padrões globais de operação. Além disso, o contato entre culturas com diferentes percepções e padrões sobre direitos humanos, por exemplo, vêm aumentando as expectativas das populações dos diversos países, que passam a exigir das empresas um comportamento socialmente responsável e que respeite as noções internacionais de direitos humanos, liberdade e participação democrática.

Nesse sentido, pode-se dizer que um dos efeitos da economia global é a adoção, por todo o mundo, de padrões éticos e morais mais rigorosos, seja pela necessidade das próprias organizações de manter sua boa imagem perante o público, seja pelas demandas diretas do público para que todas as organizações atuem de acordo com tais padrões. Valores éticos e morais sempre influenciaram as atitudes das empresas, mas estão se tornando, cada vez mais, homogêneos e rigorosos.

Portanto, a importância da responsabilidade nas organizações é reconhecida em diversas áreas e a visão de que os negócios precisam ser desenvolvidos de forma ética, com obediência a rigorosos valores morais, de acordo com comportamentos cada vez mais universalmente aceitos como apropriados, está se tornando hegemônica.

Segundo Ashley (2005, p.7), as atividades de uma organização precisam caracterizar-se por:

- Preocupação com atitudes éticas e moralmente corretas que afetam todos os públicos/stakeholders envolvidos (entendidos de maneira mais ampla possível); 
- Promoção de valores e comportamentos morais que respeitem os padrões universais de direitos humanos e de cidadania e participação da sociedade;

- Respeito ao meio ambiente e contribuição para sua sustentabilidade em todo o mundo;

- Maior envolvimento nas comunidades em que se insere a organização contribuindo para o desenvolvimento econômico e humano dos indivíduos ou até atuando diretamente na área social em parceria com governos isoladamente (Ashley, 2005, p.7)

Porém, quando se trata desse assunto o tema é polêmico e quando se referencia, em especial, à Responsabilidade Social pelas empresas, é possível apropriar das três principais teorias ${ }^{40}$ relacionadas a ela, quais sejam "Teoria do Acionista", "Teoria das Partes Interessadas" e "Teoria Contratual", esta, por exemplo, considera que a sociedade e o governo possuem suas raízes em um contrato hipotético entre os indivíduos, o que possibilita a passagem de um estado de natureza ("ficção construída para indicar uma situação anterior ao contrato") para um estado de direito (no qual o respeito às leis é um dos seus princípios fundamentais).

O bem-estar social e a justiça estabelecem os termos fundamentais do contrato hipotético entre empresa e sociedade (BARBIERI; CAJAZEIRA, 2009, p. 38). Segundo Rousseau (1999) no estado de natureza os homens são livres, iguais e pacíficos, porém o povo se torna povo com um "contrato social" e é aí que aparecem os direitos acordados na submissão de cada um a todos e, dessa forma, sem se submeter a ninguém em particular. Por esse ato cria-se um corpo moral e coletivo, que possui unidade, um eu comum, vida e vontade, o qual recebeu vários nomes, como cidade, república, ou Estado.

Não importa qual teoria venha a nortear as práticas de responsabilidade social nas organizações, para implementá-las usualmente existirá problemas, visto que as diversas questões que se traduzem em direitos, deveres e expectativas abarcam diferentes públicos, internos e externos às empresas. Há ainda mais um complicador, o qual diz respeito aos diferentes entendimentos referentes à empresa e sua relação com a sociedade e com o meio ambiente. Ademais, tudo isso ainda é realizado simultaneamente às atividades e operações da empresa a qual objetiva resultados econômicos favoráveis.

\footnotetext{
${ }^{40}$ Para saber mais sobre essas teorias, ver BARBIERE e CAJAZEIRA. Responsabilidade Social Empresarial e Empresa Sustentável: da teoria à prática. São Paulo: Saraiva, 2009, p. 9-51.
} 
De qualquer forma, a preocupação com princípios éticos, valores morais e um conceito abrangente de cultura faz-se necessária para que se constituam critérios e parâmetros apropriados para atividades empresariais socialmente responsáveis. Como destaca Ashley (2005): "há um reconhecimento de que ética, cultura e valores morais são inseparáveis de qualquer noção de responsabilidade empresarial. Afinal, o próprio fato de se considerar que uma organização tem determinadas responsabilidades para com seus interlocutores necessariamente envolve uma elaboração ética e vice-versa: qualquer reflexão sobre ética sempre tem em mente as responsabilidades percebidas como intrínsecas às organizações" (ASHLEY, 2005, p. 3).

Nesse contexto, pode-se citar a pesquisa de Souza (2014), que estuda a responsabilidade social nas empresas turísticas, e como estas estão inseridas em nosso campo de análise cabe expor brevemente $o$ assunto.

O pesquisador Souza (2014) expõe que o envolvimento de uma empresa com práticas pautadas na responsabilidade socioambiental é, comumente, determinado por ações da alta cúpula da empresa. Portanto, "as pessoas que ocupam cargo de maior influência nas tomadas de decisão, como diretores e gestores, possuem papel determinante na conduta da empresa sobre esse aspecto" (BOWEN, 1953; PELIANO, 2001, apud SOUZA, 2014, p 32). Contudo, não há concordância sobre os fatores que levam esses indivíduos a agirem de maneira responsável.

Ainda segundo esse autor, duas são as principais linhas de pensamentos ligadas às razões que levam o gestor a agir de forma responsável. A primeira linha é baseada no interesse econômico, ou seja, aqui o gestor age de forma responsável porque, para ele, essa atitude pode trazer benefícios para o seu negócio direta ou indiretamente, seja por meio da melhora na imagem da empresa ou até como fator competitivo em si. Já a segunda linha, é mais relacionada à ética, ligando o agir de forma responsável aos valores e princípios do próprio gestor, ou seja, a sua personalidade ou seu estilo de vida (PELIANO, 2001, apud SOUZA, 2014).

Ele desenvolveu um estudo com o qual é possível perceber de forma bastante concreta que no campo do turismo existem tanto as razões por parte do estilo de vida, personalidade, valores e princípios, quanto às razões ligadas ao interesse econômico. 
Desistir da karefa de reformar a sociedade é desistir da própria responsabilidade como homem livre. 
O uso do termo "responsável" na linha de pensamento que tangencia essa pesquisa tem relação com o significado de "responsável por", que diz respeito ao fato de que aqueles que estão envolvidos com o turismo devem ser responsáveis pelas consequências que esse fenômeno/atividade produz. Neste sentido, é importante deixar claro que a expectativa por atitudes responsáveis é aplicada a todos os atores e tipos de organização da cadeia produtiva do turismo. Dessa forma, aplicar essa expectativa no contexto do turismo sugere que existem facetas do turismo que são consideradas irresponsáveis e de alguma maneira antiéticas.

Além disso, como foi explicado no capítulo anterior desse trabalho, ser responsável sugere análise moral para a ação de uma pessoa e para os impactos desta. Assim, fica perceptível que a responsabilidade deve partir não só dos fornecedores de produtos e serviços de turismo, mas também pelos consumidores destes, conhecidos por turistas, hóspedes ou visitantes.

Sem dúvida, essas considerações suscitam muitas questões, não só no contexto do desenvolvimento do turismo, como também, de forma significativa, se o próprio turismo está sendo apontado como uma forma de pária ${ }^{41}$. Neste caso, poder-se-ia exigir análises comparativas de turismo com outras oportunidades de desenvolvimento econômico e com outros setores que estão fora do escopo dessa pesquisa. No entanto, esta é uma questão de pano de fundo da pesquisa, é a consideração de que se deve ter em mente ao longo desse trabalho.

O ponto de partida nesse capítulo, contudo, é a forma como o conceito de TR surgiu, isto é, como foi o histórico do desenvolvimento do turismo e porque e como ele levou à apropriação da "responsabilidade" ou de seus princípios pelo turismo.

\subsection{CONTEXTO HISTÓRICO DA EMERGÊNCIA DE OUTRO TURISMO}

A agenda de desenvolvimento ambiental dos anos de 1960 e $1970^{42}$ levou muita atenção para os impactos do turismo na década de 1980 e para a emergência e/ou

\footnotetext{
${ }^{41}$ O pária é aquele que não faz seu papel social. Ele se recusa a assumir responsabilidades por seu grupo. É leviano. Ele tem potencial, mas não faz a sua parte.

${ }^{42}$ Kavinski $(2009$, p.42-46) explica que no início do século XX ocorreram dois dos primeiros eventos mundiais destinados ao meio ambiente: a "Primeira Conferência Internacional sobre Conservação da Natureza" e o "Congresso Internacional de Proteção à Natureza". Novas conferências e convenções sobre o meio ambiente foram concretizadas nas décadas de 1940, 50 e 60, porém, mesmo com todos os esforços, o movimento ambientalista somente saiu do universo acadêmico com o agravamento da "crise ambiental", nessa última década. Por exemplo, em 1961 houve a fundação de uma das mais atuantes
} 
desenvolvimento de terminologias para descrever várias formas de turismo consideradas, de certa maneira, diferentes das que tinham surgidos antes. Por exemplo, de turismo de massa para turismo verde, sustentável ou ecoturismo (LESLIE, 2012). São termos que surgem como formas alternativas de turismo com uma associação à sustentabilidade, como o turismo ecológico, brando, soft, endêmico, ou de baixo impacto (RUSCHMANN, 2002 apud COSTA, 2013)

Esses termos surgiram no contexto do aparecimento de preocupações decorrentes do impacto das práticas agrícolas e industriais no meio ambiente físico e do rápido crescimento do turismo, particularmente na década de 1970, com o desenvolvimento dos já populares destinos de férias e da criação de novas estâncias de lazer: em efeito, o que se tornou conhecido como "turismo de massa" (LESLIE, 2012).

Em graus variados, tais termos surgiram, explícita ou implicitamente, em resposta à percepção dos impactos negativos desse tipo de turismo, o turismo de massa - ou seja, substancial e maciço fluxo de turistas para destinos desenvolvidos ou em desenvolvimento, muito facilitado pelos operadores turísticos e pelos pacotes turísticos por eles oferecidos (LESLIE, 2012; IGNARRA, 2003).

Primeiramente a elite britânica, depois fatores como o crescimento do comércio no século XIX, e em seguida o aparecimento dos membros da classe média emergente e, posteriormente, da classe trabalhadora influenciaram o crescimento do turismo, entre outros (LESLIE, 2012).

Percebe-se que na medida em que o capitalismo se desenvolveu até alcançar o nível industrial, os grandes movimentos turísticos do século XIX surgiram, sobretudo, nos países da Europa Ocidental e na América do Norte. Inúmeras decorrências dessa segunda fase do capitalismo (a primeira foi o capitalismo comercial ou mercantil) marcaram o século XIX e contribuíram para o fortalecimento do turismo (TRIGO, 2003).

entidades ambientalistas do mundo - o "Fundo Mundial da Natureza" (World Wildlife Found - WWF). No ano seguinte, o lançamento da obra da bióloga americana Rachel Carson "Primavera Silenciosa" (Silent Spring), considerada um marco por relacionar o uso de agrotóxicos ao desaparecimento de espécies. Seguida pela Conferência Intergovernamental para o Uso Racional e a Conservação da Biosfera, organizada pela UNESCO, em 1968, e, no mesmo ano, a publicação do relatório "Limites do Crescimento: um relatório para o projeto do Clube de Roma sobre o dilema da humanidade". Em 1972, ocorreu a "I Conferência das Nações Unidas sobre o Meio Ambiente Humano" (Conferência de Estocolmo), que teve como resultados a criação do Programa das Nações Unidas para o Meio Ambiente (PNUMA) e de órgãos nacionais de proteção ao meio ambiente ao redor do mundo, além da incorporação do desenvolvimento na pauta das discussões ambientais. 
Apesar do turismo não ser um fenômeno recente, ele tornou-se mais acessível a grandes parcelas da população após a década de 1950. Sua democratização nos países desenvolvidos foi devido a conquistas sociais dos trabalhadores, como melhores salários, férias remuneradas e tempo livre da produção para atividades de sua escolha, com a inclusão no campo do lazer, no qual se insere o turismo (TRIGO, 2003).

Não foram somente os avanços sociais os atores da popularização do turismo, as novas tecnologias igualmente permitiram melhorias nos sistemas de transportes, comunicações e na administração desses sistemas, o que contribuiu diretamente com o crescimento do turismo. Além disso, centros culturais, esportivos e de lazer, complexos de férias e empresas especializadas na pesquisa, implantação, comercialização e divulgação de atividades destinadas ao prazer foram criados. Ao mesmo tempo, a democratização do acesso à informação, às artes, aos esportes, à cultura e o maior acesso à educação formal e informal geraram uma nova mentalidade nas pessoas, o que instigava a defesa das liberdades individuais e a qualidade de vida (TRIGO, 2003).

As mudanças sociais são testemunhadas hoje em destinos longínquos do mundo ocidental que eram destinos turísticos populares da Europa em 1700 e 1800, que experimentaram as primeiras formas de urbanização, por exemplo, Bath (Reino Unido), Baden-Baden (Alemanha), Vichy (França), e em seguida, os resorts de Nice, Biarritz e Cannes (HALL, 1998).

Conforme Leslie (2012), os anos de 1900 viram a expansão de muitos recursos e, em alguns casos, muitos destinos experimentaram uma mudança no padrão de demanda do inverno ao verão e à criação de novos balneários. Muitos desses destinos populares que experimentaram o "turismo de massa" foram facilitados pelo desenvolvimento de infraestrutura, que permitiu a chegada de milhares de turistas e, em seguida, que serviram como base para atração de outras oportunidades de desenvolvimento, tais como conferências e congressos.

Como Briassoulis (2003) ilustra bem, o turismo começa gradualmente e se espalha espacialmente na presença de políticas e regimentos favoráveis. Uma vez que um destino alcança demanda suficiente, atrai investimentos e o local se desenvolve como uma estância turística.

Seja nos destinos turísticos europeus dos séculos XIX e XX ou nos EUA, os empresários foram rápidos em aproveitar a oportunidade de prover as necessidades e 
desejos dos turistas, o que gerou um desenvolvimento do turismo de forma desenfreada, sem planejamento futuro (Swift, 1972, apud LESLIE, 2012).

Um ponto chave é que, nessa época, o turismo muitas vezes parecia existir apenas em destinos que tiveram um extensivo desenvolvimento ao longo do tempo. Sem dúvida, tal desenvolvimento pode ser alcançado em um tempo bem mais curto hoje em dia, devido à globalização, às técnicas de construção contemporânea e ao envolvimento dos operadores turísticos.

Sabe-se que a Terra não é um bem gratuito, e que nem os destinos são infinitos e, como tal, estes não são facilmente substituídos, assim, seu valor aumenta ao longo do tempo. Os processos de globalização aceleram o desenvolvimento e também dão oportunidade para os mais abastados da sociedade visitarem quase qualquer lugar, seguidos pelo menos abastados. No geral, como os meios e as oportunidades aumentam, o turismo se expande temporal e espacialmente. Consequentemente, o desenvolvimento do turismo deve ser gerido de forma adequada e eficaz.

Baseando-se nas observações de Leslie (2012), é possível constatar que durante todo esse período de desenvolvimento do turismo, certamente em termos contemporâneos, houve limitada contestação sobre os impactos do crescimento de destinos turísticos em 1800 e 1900. Em contraste, as principais preocupações foram levantadas sobre os impactos de uma população nômade na zona rural. Assim, o autor identifica que os primeiros sinais de preocupação relacionada com a ideia de um turismo responsável foram se manifestar em questões levantadas sobre o acesso ao campo e ao impacto da demanda sobre o campo, mas não no desenvolvimento de destinos turísticos.

Nos anos 1960 e 1970, até então destinos menos populares da Europa ou destinos orientais, como Índia, Nepal e Tailândia tornaram-se disponíveis pelos operadores turísticos, mas não necessariamente em seu benefício (Noronha, 1999). Nesse processo, como Briassoulis (2003) argumenta o turismo frequentemente se desenvolve de forma descontrolada com ausência de uma preocupação holística em um plano de fiscalização ou de desenvolvimento.

$\mathrm{Na}$ década de 1960, Leslie (2012) indica que a percepção de alguns setores do turismo mudou, portanto a preocupação com os impactos do turismo também se modificou. Esta foi uma época em que as principais dificuldades da demanda - tempo, renda e transporte - foram amenizadas, isso permitiu um aumento substancial na 
demanda, o que trouxe preços reduzidos. Como consequência, admitiu-se que os menos abastados da sociedade pudessem viajar para novos destinos: notadamente, no caso dos europeus do norte e do centro, para a costa norte do Mar Mediterrâneo, especialmente para a Espanha. Deste modo, os tradicionais resorts de água fria, dos países mais ao norte da Europa, desvalorizaram, não só pelo desejo do novo, por ser mais barato, e se tratarem de destinos mais quentes, mas também, como resultado de uma mudança de gostos e do desenvolvimento de opções alternativas, como por exemplo, de parques temáticos.

Sobre esse contexto, vale citar a contribuição de Joaquim (1997, p.73):

No princípio dos anos 60 , o discurso do turismo como fator de desenvolvimento económico, social e cultural era consensual. Teve um profundo impacto nas formas de vida tradicionais, contribuindo para o aumento do rendimento das famílias, para a alteração de padrões de consumo, para a mudança do papel da mulher. No entanto, seu crescimento excessivo criou uma dupla crise: por um lado, ao nível da procura internacional, assentes nas classes médias europeias, deslocada para outros destinos turísticos com características menos massificadas, provocando um abaixamento nos preços e um consequente aumento do número de turistas de recursos mais reduzidos; por outro, diminuição drástica do efeito multiplicador do turismo nas actividades de restauração, alojamento de média/elevada qualidade e nas atividades comerciais em geral. A especialização muito rápida destas regiões nas atividades turísticas conduziu a situações de crise sócio-económica, agravadas pela ausência de mecanismos de amortecimento tradicionalmente propiciados pelas atividades de auto-subsistência (JOAQUIM, 1997, p. 73).

Assim, nota-se que a partir do momento em que esses destinos do segmento de "Sol e Praia" começam a se desenvolver rapidamente, as preocupações sobre os impactos de tais desenvolvimentos sobre o meio ambiente ganham visibilidade também. Como em 1960 e 1970 as mudanças nos padrões de uso da terra e atitudes tradicionais chamaram a atenção (Swift, 1972, apud LESLIE, 2012), surgiram dúvidas sobre o desenvolvimento contínuo do turismo. Como argumentado por Romeril e Hughes-Evans (1979, p.1, apud LESLIE, 2012): "O turismo agora atingiu o ponto inevitável quando começa a destruir a beleza a qual está em busca".

Pode-se perceber que a partir daí as agências internacionais começam a notar esses impactos negativos, principalmente os conflitos entre turismo e recreação e a conservação e o uso dos recursos. Por conseguinte, diversos eventos e documentos começam a surgir para a discussão da temática. 
Cita-se que em 1960 já houve o início do reconhecimento da importância dos recursos naturais para o desenvolvimento do turismo com a criação da "União Internacional de Operadores de Turismo no exterior", atual Organização Mundial do Turismo - OMT. Essa preocupação foi afirmada em uma política, em 1971, na qual a OMT pedia aos novos destinos turísticos um planejamento cuidadoso do turismo feito por especialistas, incluindo os ecologistas (Jenner; Smith, 1992, apud LESLIE, 2012).

Ao pesquisar sobre as origens desses eventos, encontra-se que a União Internacional para a Conservação da Natureza (IUCN, agora conhecida como a União Mundial de Conservação -WCU) realizou uma conferência sobre ecologia, turismo e recreação em 1966 (IUCN/UNESCO, 1967, apud ROMERIL, 1989), e que a primeira conferência sobre turismo e conservação - organizada pela "Europa Nostra" e pela "Comissão Européia do Turismo" - foi realizada em 1973 (ROMERIL, 1989).

A partir da década de 80 , podemos nos apoiar, também, nas informações fornecidas por COSTA (2013). Assim, como já citado nesse trabalho, nesse período houve um ponto marcante para a temática, a Declaração de Manila sobre o Turismo Mundial, em 1980, a qual ressaltou a qualidade do meio ambiente como uma prioridade, a necessidade de garantir que o desenvolvimento do turismo não cause detrimento do meio ambiente (físico) e, portanto, a necessidade de um equilíbrio entre o turismo como atividade econômica e o meio ambiente, com o reconhecimento do turismo como um fenômeno social (COSTA, 2013; BORGES, 2013; JOAQUIM, 1997).

De acordo com Lanfant (1991, apud JOAQUIM, 1997, p. 75-76), Manila representou uma mudança de orientação, pois com ela foi empreendida "uma vasta operação ideológica com vista à promoção de uma nova concepção de turismo, ultrapassando os objetivos econômicos sempre tidos como prioritários, (...) exaltando os aspectos mais nobres do turismo a serviço do homem nos domínios sociais, educativos, políticos e culturais".

Seguida a essa Declaração houve a iniciativa do Pnuma (Programa das Nações Unidas para o Meio Ambiente) para promover o desenvolvimento do turismo ambientalmente saudável, em 1982 (COSTA, 2013; ROMERIL, 1989). Vale observar que as considerações sociais nesse período não eram ainda levadas em conta.

À medida que os anos de 1980 se desenrolavam, a percepção dos impactos negativos do turismo sobre o ambiente físico aumentava, no entanto, a atenção a áreas- 
chave, como a poluição, o uso da água e da energia em espaços de oferta turística era ainda muito limitada (JAFARI, 1986).

Em 1983, a OMT concordou que a ausência de planejamento e insuficiência pelo setor público em assumir responsabilidades, deixando o setor privado com a tarefa de desenvolver o turismo de acordo com a lógica do mercado local - o que nem sempre reflete os interesses da comunidade - é a origem da maior parte dos resultados negativos do desenvolvimento do turismo. Nesse período, encontramos a predominância de cadeias hoteleiras internacionais e operadoras turísticas (LESLIE, 2012).

Ao nível supranacional, e especialmente notável por sua introdução ao termo 'Turismo Responsável', é importante mencionar a Carta da Comissão Européia de Turismo Cultural, de 1989, a qual enfatiza a necessidade de uma política de turismo responsável em longo prazo e - como a maioria das outras iterações internacionais sobre este tema - a Carta continha diretrizes e objetivos explícitos e detalhados para o desenvolvimento do turismo. Porém, a terminologia acaba sendo posteriormente alterada para "Turismo Sustentável" (LESLIE, 2012).

$\mathrm{Na}$ medida em que se avança na década de 1990, encontra-se cada vez mais atenção a ser dada ao impacto do turismo sobre a sociedade, sobre as pessoas e sobre sua cultura. Esta preocupação foi anunciada predominantemente por Young (1973) e foi retomada por Sherman (1988), que denunciou o fluxo de turistas e problemas de atendimento no contexto de subsídio e promoção do governo (LESLIE, 2012).

No geral, na última parte do século $X X$ a crescente preocupação com o desenvolvimento do turismo é evidenciada, inicialmente orientada para a conservação do meio ambiente e, posteriormente, se expandindo para abranger as questões de impactos sociais e benefícios econômicos às comunidades anfitriãs. Apesar disso, na virada do milênio, pouco tinha sido alcançado na resolução de tais preocupações (LEW, 1999 apud LESLIE, 2012).

Estas preocupações foram expandidas para abranger a correlação de suas questões mais amplas com os objetivos do desenvolvimento sustentável, a agenda emergente da mudança climática e da necessidade premente de um turismo responsável. É essencial destacar que o turismo prevê uma base racional para a preservação do meio ambiente "construído" e para a conservação do meio ambiente "natural". Como tal, ele tem tido e continua a ter um papel importante no ressurgimento de práticas culturais em várias localidades. 
Hall (1998), em seu discurso informativo sobre conservação e turismo, defende um princípio de desenvolvimento equilibrado entre estas duas questões, ou seja, desenvolvimento com base no uso sustentável dos recursos e com a devida consideração para a qualidade de vida de todas as pessoas. A atenção aqui começa a ser dada de maneira substancial para o contexto mais amplo e a necessidade de abordar o nível e a equidade das inter-relações entre o turismo e a economia local/regional, as comunidades e o meio ambiente, refletir os objetivos da sustentabilidade e o que está implícito em um turismo com responsabilidade.

Dessa forma, verifica-se que foi na década de 90 que ocorreu uma solidificação de diversos eventos, documentos e declarações que constituíram passos essenciais à demanda de um "outro" turismo, consequentemente, fatos que influenciaram o aparecimento do movimento do TR. Para uma melhor visualização do movimento ocorrido nesse período, os marcos sucedidos próximos ou durante a última década do século XX, foram resumidos e ordenados cronologicamente no Quadro 02 a seguir:

Quadro 02

Passos Essenciais ao Movimento do Turismo Responsável

\begin{tabular}{|c|c|}
\hline & RESPONSÁVEL \\
\hline 1989 & $\begin{array}{l}\text { - Declaração de Haya sobre Turismo - (ONU e União interparlamentar) - assinala } 10 \\
\text { princípios inspiradores para as ações conjuntas entre setor público, setor privado e } \\
\text { profissionais do turismo. Promove a ideia de planejamento turístico com desenvolvimento } \\
\text { duradouro. }\end{array}$ \\
\hline 1992 & $\begin{array}{l}\text { - Eco } 92 \text { ou Rio } 92 \text { - Conferência das Nações Unidas sobre Meio Ambiente - RJ, Brasil. } \\
\text { Construção do conceito de Turismo Sustentável com preocupação na integridade cultural e do } \\
\text { meio ambiente. Concepção da Comissão de Desenvolvimento Sustentável na ONU. } \\
\text { - Agenda } 21 \text { - enumera as áreas prioritárias de ação para o setor do turismo a fim de fomentar } \\
\text { a sustentabilidade. } \\
\text { - Preocupação com o turismo - WWF publica "Beyond the Green Horizon" - uma discussão } \\
\text { sobre princípios do Turismo Sustentável }\end{array}$ \\
\hline 1995 & $\begin{array}{l}\text { - Carta do Turismo Sustentável de Lanzarote - organizada pela Conferência Mundial de } \\
\text { Turismo Sustentável - sinaliza um plano de ação para o TS, pioneira no entendimento da } \\
\text { sustentabilidade no tripé que envolve equilíbrio ambiental, econômico e social. }\end{array}$ \\
\hline 1997 & $\begin{array}{l}\text { - Declaração de Berlim - determina como medidas de planejamento e prevenção a } \\
\text { necessidade de monitoramento das atividades turísticas, inventário das atividades e atrativos, } \\
\text { restrição para práticas turísticas em certas áreas e restrição ao uso inadequado de bens } \\
\text { naturais. }\end{array}$ \\
\hline 1999 & $\begin{array}{l}\text { - Comissão de desenvolvimento sustentável - ONU - discute o turismo sustentável em } \\
\text { Nova York; } \\
\text { - UNWTO (OMT) publica o Código de Ética Mundial para o Turismo - 1999, com o propósito } \\
\text { de promover uma ordem mundial no turismo, com a defesa de um turismo equitativo, } \\
\text { responsável e sustentável, que envolva todos os setores da sociedade. }\end{array}$ \\
\hline 2002 & $\begin{array}{l}\text { - Declaração de Quebec sobre Ecoturismo - Defini agenda preliminar e um compilado de } \\
\text { sugestões pautadas no desenvolvimento sustentável para o incremento do ecoturismo. } \\
\text { - Rio }+\mathbf{1 0} \text { - Cúpula Mundial do Desenvolvimento Sustentável de Johanesburgo - Evento para } \\
\text { discussão e avaliação dos resultados da Eco } 92 \text {. Entendimento do turismo sustentável como } \\
\text { estratégia para o desenvolvimento sustentável. }\end{array}$ \\
\hline
\end{tabular}

Fonte: Adaptado de COSTA (2013); GOODWIN (2012); NASCIMENTO (2012). 
Visto isso e diante das informações apresentadas até aqui, foi possível perceber que o contexto histórico mundial de apreensões sobre a sustentabilidade influenciou o aparecimento das preocupações com a responsabilidade e de seus desdobramentos no planejamento e no desenvolvimento do turismo, o que fez surgir o que o Professor Harold Goodwin (2012) chama de "movimento" do Turismo Responsável ${ }^{43}$. Conceitos e contextos que serão aprofundados nos próximos tópicos desse capítulo.

\subsection{CONCEITUAÇÃO DO TURISMO RESPONSÁVEL}

Leslie (2012) afirma que, como um termo, TR pode ser geralmente atribuído ao final dos anos 80 , embora, certamente de forma mais explícita somente na década de 90 .

Apesar dessa afirmação, vale ressaltar, que Nicholas Hetzer em 1965 publicou um artigo em que já citava o termo "turismo responsável" de forma pontual. Esse autor é assinalado por muitos como o criador do termo "ecoturismo". Foi também o responsável por propor à ONU a criação de uma entidade responsável pelo "design, promoção e implementação do turismo responsável ('alternativo') (...) - um turismo ecológico (ecoturismo)" $^{\text {"44 }}$ (HETZER, 1965).

É importante mencionar que o termo "turista responsável" já é citado por Krippendorf em 1989 ao fazer uma reflexão sobre a sociologia do turismo, na qual realizou uma nova compreensão do lazer e das viagens. Além de sugerir a viagem como forma de enriquecimento de nossa condição humana, o autor enfatiza a importância de ser um consumidor crítico, conseguindo o encontro de si próprio durante as férias e exercitando um comportamento sensível. Sobre esse assunto, pode-se citar sua seguinte afirmação:

Um turista responsável é um consumidor que demonstra uma atitude crítica não apenas da vida cotidiana, mas também quanto à escolha da viagem. Ele se mostra crítico em relação às diversas ofertas - mas também em relação a si mesmo. (...) Rebela-se contra a prática do mercantilismo turístico, onde os preços são mais importantes que os países hospedeiros. Medita nas consequências que suas compras e seu comportamento poderiam engendrar e pergunta-se a quem beneficia e a quem prejudica a viagem [grifo nosso] (KRIPPENDORF, 1989, p. 211-212, grifo nosso).

\footnotetext{
43 "Responsible Tourism has many of the characteristics of a social movement" (GOODWIN, 2012, p.04).

${ }^{44}$ Texto original: "design, promote and implement responsible ('alternative') tourism (...) - an ecological tourism (eco-tourism)".
} 
No mesmo ano que esse autor faz menção ao termo "turista responsável", 1989, a ONU toma a iniciativa de organizar um seminário internacional sobre turismo alternativo, de onde se tem a origem de sua definição para "turismo responsável" (ainda expresso com letras minúsculas). Percebe-se que esse conceito criado pela ONU corrobora a relação existente entre responsabilidade e respeito, que foi mencionada no Capítulo 2, como pode ser conferido no seguinte trecho:

Turismo responsável diz respeito a todas as formas de turismo que respeitem os patrimônios natural, construído e cultural das sociedades de acolhimento e os interesses de todas as partes envolvidas: habitantes, hóspedes, visitantes, indústria, governo, etc (LANFANT, 1991, p. 4, apud JOAQUIM, 1997).

Ao se buscar também a origem do termo "Turismo Responsável", encontra-se que um dos primeiros autores a utilizar e defender o termo como o mais adequado para um turismo alternativo, contraposto a um turismo de massa, foi Richard Davidson, em 1992. Ele destaca as suas características:

Usa recursos que pertencem e/ou são geridos pelas comunidades de acolhimento; traduz-se em empresas de pequena dimensão; privilegia o contato direto entre as populações locas e os visitantes, enfatizando o entendimento mutuo e igualitário entre ambos; privilegia um desenvolvimento amigo do ambiente; caracteriza-se pela autenticidade; se assenta nas potencialidades locais (DAVIDSON 1992, apud JOAQUIM, 1997, p.86).

Nessa mesma década, porém um ano antes de Davidson, Brian Wheeller explica o conceito de TR de uma maneira a introduzir a importância do processo de decisão sobre o turismo estar sob a gerência das comunidades locais. Assim, sua conceituação resume-se na seguinte definição:

Com algumas variações o turimo responsável pode ser interpretado como um chapéu que abarca as supostas formas de turismo preocupado. Os prefixos incluem alternativo, apropriado, sustentável, suave, verde, etc. Na essência, prefere-se o viajante ao turista, o individual ao grupo, o operador independente especializado é mais aceitável que as grandes firmas, as acomodações locais são preferíveis aos hotéis de cadeias internacionais, etc - basicamente 'pequeno' versus 'massas'. O passo do desenvolvimento também é vital - deve ser controlado, relativamente lento e capaz de ser absorvido pelo ambiente local sem repercussões negativas. A base de poder deve ser alterada e o processo de decisão sobre turismo e desenvolvimento turístico deve estar nas mãos das comunidades de acolhimento. Elevar o conhecimento do viajante é considerado um elemento vital - a educação é vista como uma espécie de chave (WHEELLER, 1991, p 92, apud JOAQUIM, 1997). 
Apesar da criação desse conceito, o mais interessante é que, como indica Joaquim (1997), esse autor assume uma perspectiva extremamente crítica em relação ao turismo responsável por considerar que se trata de uma resposta inadequada ao problema de turismo de massas.

No início dos anos 2000, a conceituação do termo já se torna mais comum, o que nos permite citar conceitos formulados por autores e até mesmo por instituições ou governos. Por exemplo, a WWF criou um conceito simples em 2001, o qual diz que:

O Turismo Responsável, no contexto de uma estratégia para a sustentabilidade ampla nos destinos turísticos, é aquele que mantém e, onde possível, valoriza as características dos recursos naturais e culturais dos destinos, sustentando-as para as futuras gerações de comunidades, visitantes e empresários (WWF apud SALVATI, 2004, p.16).

Já Salvati, em 2002, institui um conceito um pouco mais amplo, que já está mais próximo do referencial atual. Ele afirma que Turismo Responsável é:

Um conjunto de bens e serviços que promovem o desenvolvimento socialmente justo e economicamente equilibrado em nível local e regional, integrando o desenvolvimento urbano e rural e criando um processo de desenvolvimento econômico diversificado. Manter, valorizar e proteger as paisagens naturais e sua diversidade biológica, assim como o patrimônio histórico-cultural, é a base essencial para o desenvolvimento responsável do turismo, contribuindo para a sua manutenção em longo prazo (SALVATI, 2002 apud SALVATI, 2004, p. 16).

Sobre essa temática, Harold Goodwin - pesquisador da atualidade e um grande estudioso e defensor do Turismo Responsável - fornece conceitos e realiza discussões e análises sobre o assunto. Para Goodwin, Turismo Responsável diz respeito à tomada de responsabilidade, respondendo e tomando medidas para resolver os problemas de sustentabilidade, que surgem nos destinos, relacionadas ao social, econômico e ambiental.

[Turismo Responsável] tem a ver com fazer algo. Tem a ver com fazer a diferença. É nos destinos que turistas e comunidades locais interagem na natureza local e no ambiente sociocultural. É nos destinos que o turismo precisa ser administrado para que minimize os impactos negativos e potencialize os positivos. A administração do turismo nos destinos não pode ser reduzida à agenda ambiental, é também importante considerar os aspectos econômicos e 
sociais que surgem nos destinos [tradução livre]. ${ }^{45}$ (GOODWIN, 2012 apud GOODWIN; FONT; ALDRINIQUE, 2012, p.399).

Esse autor preocupa-se em alertar que as decisões precisam ser tomadas localmente, já que os destinos do nosso mundo são muito diversificados e os problemas e as questões mudam de local para local. Para ele, o Turismo Responsável celebra a diversidade e reconhece que enquanto os destinos podem aprender com o que foi feito em outros lugares, todas as soluções são locais, o que exige o engajamento de um único conjunto de stakeholders. As questões e prioridades, ele reforça, variam de lugar para lugar, então apenas as soluções que abordam as particularidades são suscetíveis de obterem sucesso (GOODWIN, 2011).

Ademais, não há necessidade de definir uma lista de questões. Na verdade o Turismo Responsável não foi prescrito, nem deve ser. Portanto, o desafio é cada agente - governos, comunidades, empresas e viajantes - determinar o que vai fazer, como vai reagir e assumir a responsabilidade de tornar o turismo mais sustentável e solidário (GOODWIN, 2012).

É relevante ressaltar, que o Turismo Responsável não é outro "segmento" ou "nicho" de turismo, não é um tipo de turismo, e sim uma forma de se fazer turismo. Ademais, usualmente verifica-se a associação do Turismo Responsável somente com o Ecoturismo ou com o Turismo de Base Comunitária. Isto é um equívoco, visto que qualquer segmento de turismo ${ }^{46}$ (por exemplo: Turismo de Negócios, Turismo Cultural, Turismo Religioso até mesmo o Turismo de Massa) pode se tornar responsável a partir da sensibilização sobre a importância do Turismo Responsável e do engajamento de todos os envolvidos no processo.

Destaca-se, ainda, que o tamanho da empresa também não importa - grandes empresas conseguem realizar amplas ações responsáveis, mas igualmente os pequenos negócios possuem sua parcela de responsabilidade, eles são essenciais na construção do Turismo Responsável (GOODWIN, 2012).

\footnotetext{
${ }^{45}$ It is about doing something about it. It is about, making a difference. It is in destinations that tourists and local communities interact in the local natural and socio-cultural environment. It is in destinations that tourism needs to be managed in order to minimize negative impacts and to maximize positive ones. The management of tourism in destinations cannot be reduced to the environmental agenda, it is as important to consider the economic and social issues that arise in destinations.

${ }^{46}$ Sobre SEGMENTAÇÃO TURÍSTICA vide ANSARAH, M. G. R. Turismo - Segmentação de Mercado. Ed. Futura, São Paulo. 2001
} 
Corroborando com essa ideia, pode-se citar o documento "Responsible Tourism in Cape Town":

\begin{abstract}
Turismo Responsável não é outra forma de 'turismo de segmento' - Turismo Responsável tem a ver com legalidade e as consequências do turismo - para o meio-ambiente, comunidade local e economia local. Turismo Responsável não acontece somente em lugares de ambientes naturais - Qualquer negócio de turismo, localizado em metrópoles em desenvolvimento, um deserto, zona rural, ilha subtropical, cidade medieval - pode está relacionada com operações de Turismo Responsável. Turismo Responsável é de responsabilidade de grandes negócios - $\mathrm{O}$ administrador do menor negócio de turismo já está praticando Turismo Responsável [tradução livre]. ${ }^{47}$ (ÁFRICA DO SUL, 2007, p.02).
\end{abstract}

Os esclarecimentos sobre os conceitos de Turismo Responsável mostram-se essenciais a essa pesquisa, uma vez que servirão como base de toda análise por se tratar do principal conceito para a construção do referencial teórico do trabalho. Como explicado acima, muitas vezes TR é entendido equivocadamente como um segmento. Da mesma forma, é comum seu entendimento como sinônimo de Turismo Sustentável. Já que há essa confusão sobre esses dois conceitos, acredita-se ser importante esclarecer as diferenças existentes entre eles.

Para isso, recorremos novamente a Goodwin (2012), que esclarece que Turismo Responsável e Turismo Sustentável são distintos, apesar de cada vez mais notar-se as palavras "responsável" e "sustentável" sendo usadas em conjunto, com a descrição da mesma coisa. Esses conceitos estão sim relacionados, porém eles não possuem o mesmo significado. Turismo Responsável é assumir responsabilidades para alcançar o desenvolvimento sustentável por meio do turismo. "Turismo Responsável não se trata de se criar longas listas de verificações, mas sim de se identificar as questões econômicas, sociais e ambientais as quais sejam importantes localmente e ultrapassá-las" (GOODWIN, 2012, p.08).

Como é citado no documento sobre "Progress in ResponsibleTourism Vol 2 (1)", o único problema global relacionado com o Turismo Responsável é a mudança climática,

\footnotetext{
${ }^{47}$ Responsible Tourism is not another form of 'niche tourism' - Responsible Tourism is about the legacy and the consequences of tourism - for the environment, local people and local economies. Responsible Tourism does not only take place in protected natural environments - Any tourism business, whether located in a thriving metropolis, a desert, rural village, sub-tropical island, medieval town - can be Responsible Tourism operations. Responsible Tourism is the responsibility of big business - The smallest of owner managed tourism business are already practicing Responsible Tourism (ÁFRICA DO SUL, 2007, p.02).
} 
pois o TR está relacionado diretamente ao local, enquanto que o TS relaciona-se muitas vezes com os problemas globais.

A principal diferença entre os dois conceitos é que no Turismo Responsável, indivíduos, organizações e empresas são convidados a assumirem a responsabilidade por suas ações e os impactos de suas ações. Segundo o mesmo documento citado, esta mudança de ênfase ocorreu porque não houve muito progresso na realização do Turismo Sustentável nos últimos 20 anos desde a "Earth Summit" - ECO - 92, no Rio de Janeiro. "Isto é em parte porque todo mundo fica esperando os outros para ser responsável" (GOODWIN, 2012, p.02). A ênfase no Turismo Responsável coloca a tarefa firmemente nas mãos de todos os envolvidos no turismo - governo, os proprietários do produto e operadores, operadores de transportes, serviços comunitários, ONGs, turistas comunidades locais, associações da indústria (GOODWIN, 2012).

Apesar de não possuíram exatamente o mesmo significado, percebe-se que eles são similares quanto ao objetivo - ambos buscam o desenvolvimento sustentável. Os pilares do Turismo Responsável, portanto, são os mesmos nos quais se fundamenta o Turismo Sustentável - a integridade ambiental, justiça social e maximizar os benefícios econômicos locais (GOODWIN, 2012).

Finalmente, após a explicação do que seria o Turismo Responsável, pode-se inseri-lo no contexto atual que envolve o que Harold Goodwin chama de "movimento" do TR.

\subsection{ORIGEM DO "MOVIMENTO” DO TURISMO RESPONSÁVEL}

O pré-movimento das políticas de Turismo Responsável significou os primeiros passos percorridos para que fosse alcançado o seu conceito utilizado atualmente. Já se adentrou nesse assunto no tópico anterior ao se traçar a contextualização histórica da apropriação da responsabilidade pelo turismo, no entanto, agora serão ressaltados pontos ligados especificamente ao contexto da origem do próprio movimento.

Goodwin (2005) assegura que Jost Krippendorf foi o articulador do caso mais relevante de Turismo Responsável por meio da publicação "The Holiday Makers" em 1984 em alemão e em 1987 em inglês. Esse autor foi o visionário que reconheceu que a "emancipação do turista" era possível, já que os turistas estavam se tornando mais demandantes e com isso solicitavam mais contato com outras pessoas e realização 
pessoal por meio de atividades criativas, conhecimento e desbravamento de novos locais (GOODWIN, 2005; KRIPPENDORF, 1987).

Goodwin (2005) ao citar Krippendorf em seu artigo diz que:

Ele antecipou uma 'evolução partindo de um turista manipulado para um turista informado e experiente, para um turista emancipado e independente, um consumidor crítico não apenas em casa, mas também viajando'. Isto está no cerne do movimento do Turismo Responsável (tradução nossa) (GOODWIN, 2005, p.02,). ${ }^{48}$

E, ainda, completa:

Sua visão foi 'desenvolver e promover novas formas de turismo as quais trarão um maior benefício possível para todos participantes - viajantes, comunidade local e o setor turístico, sem causar danos intoleráveis ecológica e socialmente'. (tradução nossa) (GOODWIN, 2005, p.02) ${ }^{49}$.

Corroborando com essa ideia de responsabilidade, ética e sustentabilidade no turismo, desde meados da década de noventa, duas ONGs britânicas, a Voluntary Service Overseas (VSO) e a Tearfund, iniciaram uma campanha para um turismo ético, buscando sensibilizar os consumidores e desafiando os operadores turísticos sobre suas práticas. Assim, a Voluntary Service Overseas (VSO) voltou sua atenção para o turismo e começou uma campanha intensa nessa linha.

De acordo com uma pesquisa realizada por voluntários pertencentes à VSO nos países em desenvolvimento, o impacto do turismo em comunidades foi constatado como uma causa de grande preocupação. Ao mesmo tempo, foi esclarecendo que os turistas queriam estar mais bem preparados para as suas viagens aos países em desenvolvimento e que eles achavam que os operadores turísticos eram os responsáveis em prover-Ihes com melhores informações sobre as sociedades que estavam visitando.

Travelling in the Dark, publicado também pela VSO em 1999, utilizou um sistema de pontuação transparente para criar tabelas classificativas, o que chamou a atenção dos operadores turísticos. A VSO pesquisou 50 empresas do Reino Unido que ofereciam

\footnotetext{
${ }^{48}$ Texto original: "He anticipated a "development away from a manipulated tourist to an informed and experienced one, to an emancipated and independent tourist, a critical consumer not only at home but also when travelling." This is at the core of the responsible tourism movement". (GOODWIN, 2005, p.02).

${ }_{49}$ Texto original: "His vision was "to develop and promote new forms of tourism, which will bring the greatest possible benefit to all the participants - travellers, the host population and the tourist business, without causing intolerable ecological and social damage". (GOODWIN, 2005, p.02).
} 
pacotes de viagens aos países em desenvolvimento nos quais havia voluntários da VSO trabalhando (GOODWIN, 2005). Como resultado dessa pesquisa descobriram que dois terços dos entrevistados não conseguiram atingir um padrão mínimo ao fornecer informações prévias sobre o local da viagem nem sobre a população local e os costumes locais, como também sobre os produtos e serviços locais e a conservação do meio-ambiente. A VSO afirmou que a provisão deste tipo de informação para viajantes pelos operadores turísticos era "um direito, não um luxo" (VSO -Travelling in theDark, 1999 apud GOODWIN, 2005, p.01)

Queremos interagir com a população local e desfrutar de um novo ambiente quando visitamos um país em desenvolvimento, mas muitas vezes não temos a orientação de que precisamos para obter o máximo de nossas férias sem prejudicar costumes e cultura locais [tradução nossa] (VSO Travelling in the Dark, 1999 apud GOODWIN, 2005, p.01) ${ }^{50}$.

Ao final de 1999, um levantamento das empresas pertencentes à AITO (Associação de Operadores Turísticos Independentes) revelou o quanto alguns de seus membros já estavam praticando o Turismo Responsável, e que havia uma quantidade significativa de apoio para a associação adotar uma política de Turismo Responsável. Membros da AITO identificaram uma série de razões para a adoção de uma abordagem ética e responsável. Mais da metade dos entrevistados disseram que eram a favor da adoção de uma política responsável por razões de consciência, devido aos seus valores pessoais ou por causa de suas preocupações com o meio ambiente e a cultura. Cerca de um quarto se referiu à necessidade de preservação e manutenção de destinos e produtos. Segundo essa pesquisa, menos de um em cada cinco dos entrevistados se referiu, como motivo de adoção de uma política responsável para o turismo, às forças do mercado e pressão do consumo (GOODWIN, 2005)

Como consequência, em 2000 a AITO reconheceu que:

Ao desempenhar nosso trabalho como Operadores Turísticos nós temos a responsabilidade de respeitar o lugar das outras pessoas e seu modo de vida. Nós reconhecemos que onde quer que o operador turístico faça negócio ou envie clientes ele tem o potencial tanto de beneficiar quanto de prejudicar, e nós

\footnotetext{
50 Texto original: "We want to interact with local people and enjoy a new environment when we visit a developing country, but all too often we don't have the guidance we need to get the most from our holiday without undermining local customs and culture." (VSO Travelling in the Dark, 1999 apud GOODWIN, 2005, p.01).
} 
sabemos que quase sempre no passado os malefícios foram maiores que os benefícios [tradução nossa]. ${ }^{51}$ (GOODWIN, 2012, p. 07).

Com isso, cerca de 150 empresas especializadas predominantemente geridas pelo próprio proprietário da Associação de Operadores Turísticos Independentes (AITO) adotaram uma política de Turismo Responsável. Em 2002, uma pesquisa da indústria com os consumidores confirmou que estes se preocupavam com os impactos de suas férias nos destinos e estavam exigindo informações sobre esses impactos (GOODWIN, 2012)

Concomitantante a essas ações na prática do âmbito do mercado turístico, alguns governos começaram a perceber, também, esse contexto emergente e iniciaram trabalhos voltados a fomentação do TR no campo político. Nesse contexto, ressaltamos o Governo da África do Sul. Este, em 1996, publicou o "White Paper on The Development and Promotion of Tourism in South Africa", sendo assim o primeiro país a explicitamente comprometer-se com o Turismo Responsável (GOODWIN, 2012). Neste documento, o setor de turismo foi identificado como uma oportunidade perdida, visto que existiam limites na integração das comunidades locais e grupos envolvidos. O Turismo Responsável foi definido no "White Paper" como:

(...) o turismo que promove a responsabilidade com o meio ambiente por meio da sua utilização sustentável; responsabilidade em envolver as comunidades locais no setor do turismo, responsabilidade pela segurança dos visitantes e do governo responsável, os empregados, os empregadores, os sindicatos e as comunidades locais (tradução livre). ${ }^{52}$ (GOODWIN, 2012, p. 07)

Pioneira no tema, a Cidade do Cabo sediou a primeira Conferência Internacional sobre Turismo Responsável em Destinos, em 2002. Esse evento envolveu 280 delegações de 20 países. Essa Conferência foi realizada para reunir tanto aqueles que trabalham em destinos como aqueles que trabalham nos mercados originários:

\footnotetext{
${ }^{51}$ Texto original: "(...) in carrying out our work as Tour Operators we have a responsibility to respect other people's places and ways of life. We acknowledge that wherever a Tour Operator does business or sends clients it has a potential to do both good and harm, and we are aware that all too often in the past the harm has outweighed the good." (GOODWIN, 2012, p. 07).

${ }^{52}$ Texto original: "(...) tourism that promotes responsibility to the environment through its sustainable use; responsibility to involve local communities in the tourism industry; responsibility for the safety and security of visitors and responsible government, employees, employers, unions and local communities "(...) (GOODWIN, 2012, p. 07)
} 
A Conferência da Cidade do Cabo reuniu operadores turísticos emissores e receptores, empreendedores emergentes na indústria do Turismo, Parques Nacionais, autoridades de conservação provinciais, todas as esferas do Governo, profissionais do turismo, autoridades do setor turístico, ONG's, grupos hoteleiros e outros atores do turismo, da África, Américas do Norte e do Sul, Europa e Ásia, para levarem em consideração o que o Turismo Responsável poderia oferecer (tradução livre).. ${ }^{53}$ (GOODWIN, 2012, p.04)

Em meio a vários observadores internacionais, tais como a World Tourism Organization (UNWTO), United Nations Environment Programme (UNEP), Organização das Nações Unidas para a Educação, a Ciência e a Cultura (UNESCO), discutia-se o turismo como instrumento capaz de contribuir para a transformação positiva de lugares. A proposta do Turismo Responsável é uma contribuição do desenvolvimento do turismo para melhoria da qualidade de vida dos moradores dos destinos turísticos em desenvolvimento, utilizando-se, assim, o turismo como mola propulsora na criação de lugares melhores para se viver - "better places for people to live, and better places for people to visit" ${ }^{\prime 4}$.

$\mathrm{Na}$ verdade, essa Conferência foi um chamado aos governos, aos gestores de negócios do turismo, turistas e comunidades locais para assumirem suas responsabilidades na busca da sustentabilidade do turismo, já que todos os envolvidos no "Sistema do Turismo - Sistur" 55 têm sua parcela de responsabilidade na construção de um turismo mais ético e sustentável. O que se percebe de fato é que se faz mister um trabalho de base num direcionamento educacional para que cada ator envolvido com a atividade turística transforme seu local em excelência de viver, tendo como consequência, um lugar especial para se visitar (Cape Town Declaration on Responsible Tourism, 2002).

A Declaração da Cidade do Cabo foi discutida durante essa Conferência e chamou a atenção de diversos atores - governos nacionais e locais, planejadores, gestores de negócios do turismo, turistas e comunidades locais - para "assumirem responsabilidades na busca da sustentabilidade do turismo, para criarem melhores

\footnotetext{
53 Texto original: "Cape Town Conference brought together inbound and outbound tour operators, emerging entrepreneurs in the tourism industry, national parks, provincial conservation authorities, all spheres of government, tourism professionals, tourism authorities, NGOs, hotel groups and other tourism stakeholders, from Africa, North and South America, Europe and Asia, to consider what Responsible Tourism might have to offer". (GOODWIN, 2012, p.04)

${ }^{54}$ Cape Town Declaration in Responsible Tourism. 2002.

${ }^{55}$ Conceito criado pelo Professor Dr. Mário Carlos Beni em seu livro “Análise Estrutural do Turismo", 2003.
} 
lugares para as pessoas viverem e turistas visitarem" (Cape Town Declaration on Responsible Tourism, 2002).

Assim, percebe-se que essa declaração reconheceu que a responsabilidade da realização de um turismo responsável é de todos, pois para que ele funcione é preciso que seja exercido pelos governos, comunidades, empresas e também pelos consumidores. Além da participação de todos envolvidos com a área faz-se "necessário o uso de um portfólio de ferramentas, incluindo regulamentos, incentivos e estratégias participativas de diversos stakeholders. Campanhas de consumo e novas iniciativas de marketing também contribuem para mudanças no mercado" (GOODWIN, 2012, pág.8). "Declaração de autoridades locais foi identificada como tendo um papel central" para o desenvolvimento sustentável por meio do turismo, já que elas representam as comunidades locais e gerenciam os destinos (GOODWIN, 2012).

No mesmo evento foram definidas as características do Turismo Responsável e listadas na Declaração da Cidade do Cabo (Cape Town Declaration on Responsible Tourism, 2002). Essas características serão apresentadas, a seguir, na Figura 06.

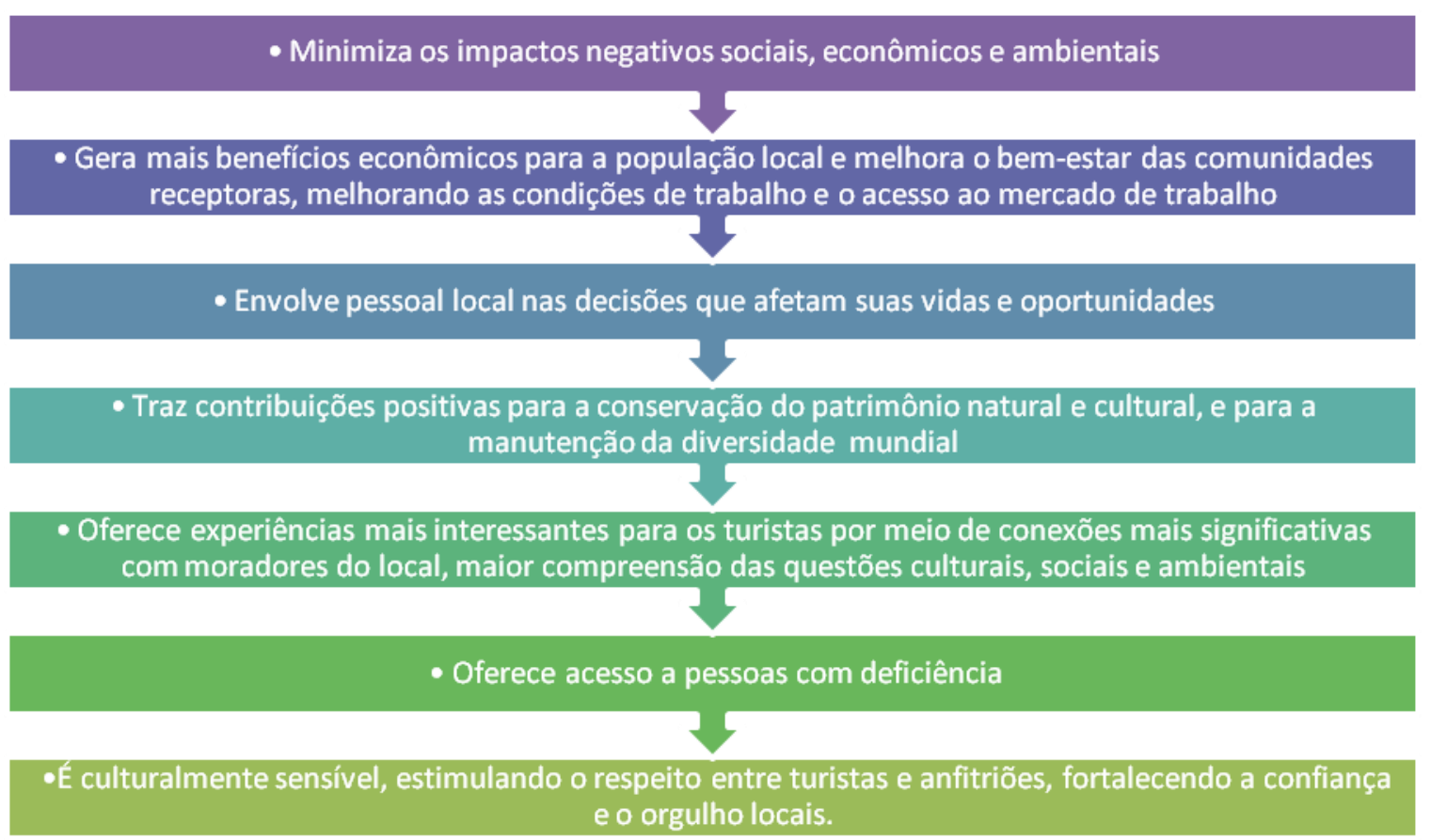

Figura 06 - Características do Turismo Responsável Fonte: Adaptado da Declaração da Cidade do Cabo (2002) 
Além dessas características, o documento determina princípios norteadores para o desenvolvimento do Turismo Responsável. Esses princípios estão divididos em "Princípios orientadores para a responsabilidade econômica", "Princípios orientadores para a Responsabilidade Social" e "Princípios orientadores para a Responsabilidade Ambiental".

O movimento do Turismo Responsável ganhou força e hoje continua a se espalhar pelo mundo. Após a primeira conferência na África do Sul, as conferências seguintes foram realizadas em Kerala no ano de 2008; Belize em 2009; Omã, 2010; Alberta em 2011; São Paulo em 2012, Barcelona em 2013 e Manchester em 2014. Para a Conferência de 2012, no Brasil, a questão principal era analisar e avaliar os resultados do projeto nos últimos 20 anos. Quatro perguntas foram dirigidas aos palestrantes convidados: Quais são os avanços de governos e organizações internacionais para o desenvolvimento sustentável? Como as empresas podem contribuir para o desenvolvimento econômico, garantindo sustentabilidade? Quais são as razões que levam ao sucesso ou fracasso de projetos financiados por doadores? $O$ que aprendemos em 20 anos para o desenvolvimento sustentável nas comunidades? (GOODWIN, 2012). Cabe ressaltar que o Brasil foi o único país que sediou o evento e não produziu um documento sobre Turismo Responsável no país.

Nessa $6^{\text {a }}$ Conferência Harold Goodwin iniciou sua apresentação sobre "Dez anos de Turismo Responsável (GOODWIN, 2012) - Quais lições" e afirmou que como "vamos de férias em casas de outras pessoas" devemos assegurar que a comunidade receptora tenha algum benefício. Segundo o cientista, "Ecoturismo", "Créditos de Carbono" e "Turismo verde" fracassaram como estratégias para um turismo sustentável. Para ele, todos os tipos de turismo devem ser sustentáveis e responsáveis. Afirma, também, que as pessoas são a chave para a mudança - quando o seu orgulho em participar de práticas sustentáveis melhora a sua qualidade de vida, reflete na qualidade da experiência do turismo local. Finalizou sua palestra assegurando que há necessidade em se divulgar informações, educando o mercado de origem, bem como trabalhar o destino (GOODWIN, 2012 apud GOODWIN; FONT; ALDRIQUINI, 2012, p.400).

Em "Progress in Responsible Tourism"56, Goodwin explica que:

\footnotetext{
${ }^{56}$ GOODWIN, Harold e FONT, Xavier. Progress in Responsible Tourism, Vol 2 (1), 2012.
} 
O desafio do Turismo Responsável é utilizar o turismo para atingir o desenvolvimento sustentável; a aspiração do Turismo Responsável é usar o turismo ao invés de ser usado por ele. Não é possível definir com precisão o que significa Turismo sustentável, ele descreve uma aspiração - que ecoa desenvolvimento sustentável com seus tons paradoxais. O Turismo Responsável exige que aqueles com a oportunidade, com a capacidade e com o poder de fazer turismo mais sustentável respondam ao desafio, que eles assumam a responsabilidade, que eles ajam, ele 'surge da responsabilidade por meio da legislação, regulação, contrato de fornecimento e de emprego e do desejo dos indivíduos e organizações de reagir. (...) O Ecoturismo e o Turismo de Base Comunitária podem ser responsáveis, eles podem também ser irresponsáveis. $O$ teste não é a marca, mas o impacto dos negócios e dos clientes. Todas as formas de turismo podem ser mais ou menos responsáveis - Ecoturismo, Turismo de Base Comunitária, Turismo de Massa e hospedagens all-inclusives. A ambição do Turismo Responsável é modificar o setor [tradução livre]. (GOODWIN, 2012 apud GOODWIN; FONT, 2012 p. 8) (57 $^{57}$

De qualquer forma, o progresso do Turismo Responsável é perceptível. Por exemplo, explica Goodwin (2005), os operadores turísticos responsáveis atuais colocam muito mais peso hoje sobre os vínculos econômicos para se dividir os benefícios econômicos em nível local e na agenda social, e criam oportunidades para o contato mais positivo e significativo entre anfitriões e convidados. A AITO, por exemplo, reconheceu que os operadores turísticos têm o poder de fazer tanto o bem quanto o mal, e que muitas vezes no passado, o dano superou o benefício.

\footnotetext{
57 Texto original: "The challenge of Responsible Tourism is to use tourism to achieve sustainable development; the aspiration of Responsible Tourism is to use tourism rather than to be used by it. It is not possible to define with any precision what is meant by sustainable tourism. It describes an aspiration - one which echoes sustainable development with its oxymoronic overtones. Responsible Tourism demands that those with the opportunity, the capability and capacity to make tourism more sustainable respond to the challenge, that they take responsibility that they act. It 'arises both from accountability, through legislation, regulation and contracts of supply and employment and from the willingness of individuals and organizations to respond. (...) Ecotourism and community-based tourism may be responsible, they may also be irresponsible. The test is not the branding but rather the impact of the business and the clients. All forms of tourism can be more or less responsible - ecotourism, community- based tourism, mass tourism and all-inclusive. The ambition of Responsible Tourism is to change the sector".
} 
Qquilo que é comum ao maior número de pessoas despertará sobre si os menores cuidados. Todos pensam mais naquilo que thes pertence, raramente pensam no que é de interesse comum.

Qristóteles 


\subsection{CONCEITO DE POLÍTICA PÚBLICA}

Política pública é um conceito que tem sua origem na economia e na política. Esse instrumento orienta a tomada de decisões em assuntos públicos, políticos e/ou coletivos. Suas origens estão datadas no pós-guerra, entre os anos 40 e 50 nos EUA, pois nessa época surgiu a preocupação com o decrescimento econômico devido à finalização da economia gerada durante a Segunda Guerra Mundial. Além disso, o aumento da intervenção estatal, desde a experiência do "New Deal", também foi um forte fator para a criação das políticas públicas (TAPIA, 1998, apud PEREIRA, 1999).

$\mathrm{Na}$ década de 60 houve o seu fortalecimento em consequência do aparecimento da necessidade de se avaliar e de se discutir o que o governo é capaz de realizar por meio de programas, projetos e políticas; e como pode aprimorar o seu desempenho na busca de aumentar o bem estar social (TAPIA, 1998, apud PEREIRA, 1999).

Segundo Elenaldo Teixeira (2002, p. 2), "Políticas Públicas" dizem respeito a "diretrizes, princípios norteadores de ação do poder público; regras e procedimentos para as relações entre poder público e sociedade, mediações entre atores da sociedade e do Estado". Elas norteiam ações que geralmente envolvem aplicações de recursos públicos. São, usualmente, políticas explicitadas, sistematizadas ou formuladas em documentos - por exemplo: leis, programas e linhas de financiamentos. Cabe observar que nem sempre, porém, existe compatibilidade entre as intervenções e as declarações de vontade com as ações desenvolvidas.

O mesmo autor destaca que as "não-ações", dizem respeito às omissões do governo, e também devem ser consideradas como formas de manifestação de políticas, uma vez que representam opções e orientações dos que ocupam cargos.

Pereira (1999, p.8) ressalta que, no campo acadêmico, a origem das políticas públicas está pautada na tentativa de "gerar conhecimento aplicável às ações práticas dos governos, com ênfase na preocupação com a qualidade e eficácia da intervenção pública".

As políticas públicas revelam, durante o seu processo de elaboração, implantação e, especialmente, em seus resultados, as formas de exercício do poder político, ao abarcar a distribuição e a redistribuição de poder, a função do conflito social nos processos de decisão e a repartição de custos e benefícios sociais. Visto que o poder constitui uma relação social em que diversos atores - com projetos e interesses 
diferenciados ou, até mesmo, contraditórios - são envolvidos, surge a obrigação de mediações sociais e institucionais, para que, assim, seja possível se alcançar um mínimo de consenso e, portanto, a legitimação e eficácia das políticas públicas (TEIXEIRA, 2002).

Nesse contexto, Teixeira (2002) esclarece o significado e as relações de uma política pública:

\begin{abstract}
Elaborar uma política pública significa definir quem decide o quê, quando, com que consequências e para quem. São definições relacionadas com a natureza do regime político em que se vive, com o grau de organização da sociedade civil e com a cultura política vigente. Nesse sentido, cabe distinguir "Políticas Públicas" de "Políticas Governamentais". Nem sempre "políticas governamentais" são públicas, embora sejam estatais. Para serem "públicas", é preciso considerar a quem se destinam os resultados ou benefícios, e se o seu processo de elaboração é submetido ao debate público. (TEIXEIRA, 2002, p.2)
\end{abstract}

De forma objetiva, uma noção de política pública também foi dada por Hofling (2001, p.31 apud BARRETTO et al, 2003, p. 33) que explicou como sendo o "Estado em ação", "o Estado implantando um projeto de governo, através de programas, de ações voltadas para setores específicos da sociedade".

No caso do setor de turismo, Beni (2003) explica que política pública de turismo pode ser percebida como:

(...) o conjunto de fatores condicionantes e de diretrizes básicas que expressam os caminhos para atingir os objetivos globais para o Turismo do país; determinam as prioridades da ação executiva, supletiva ou assistencial do Estado; facilitam o planejamento das empresas do setor quanto aos empreendimentos e às atividades mais suscetíveis de receber apoio estatal. (BENI, 2003, p. 101)

Nesse sentido, a função das políticas públicas para a área do turismo deve ser a de proporcionar o desenvolvimento equilibrado da atividade. É papel do Estado a construção de infraestrutura de acesso e de infraestrutura básica urbana - que também atenda à população local - e o fornecimento de uma superestrutura jurídicoadministrativa, tais como secretarias e similares, cujo desempenho é planejar e controlar os investimentos que o estado realiza para, assim, fomentar o desenvolvimento da iniciativa privada, a qual é encarregada de construir equipamentos e prestar serviços 
ligados à área, para que toda sociedade receba esse retorno em forma de benefícios (BARRETTO et al, 2003, p.33).

Beni (2006, p.91) ressalta que, em uma "visão bem simplista" as políticas de turismo fazem parte do desenvolvimento planejado de uma região ou país, em que é "necessário criar, desenvolver, conservar e proteger recursos turísticos", e buscam maximizar os benefícios e minimizar os prováveis efeitos desfavoráveis do turismo.

Já Cruz (2002, p.40) diz que o objetivo geral da política pública de turismo conjunto de intenções, diretrizes e estratégias específicas para o setor - seria o de "alcançar e/ou dar continuidade ao pleno desenvolvimento da atividade turística num dado território".

Nesse contexto, Cruz (2002) faz uma importante observação:

Toda política é imbuída de intencionalidade e de ideologia. Uma política setorial revela uma forma de o poder público ver, pensar e se posicionar no mundo. Não se trata, portanto, de uma atividade, embora toda a atividade tenha algum conteúdo político. E, se toda atividade tem um conteúdo político, não é a política que decorre de uma ou de outra iniciativa, mas sim o contrário. Todas as iniciativas públicas e privadas que concorrem para o desenvolvimento de certa atividade já nascem com um conteúdo político. (CRUZ, 2002, p. 49)

Embora o conceito de política pública seja um assunto controverso, longe de um consenso entre os estudiosos desse tema, nesse trabalho será adotado aquele que se baseia nas ações governamentais, em nível federal, que trazem institucionalidade, ou seja, amparadas legalmente por programas, projetos, planos, metas e orçamento público, especificamente, criadas e lançadas pelo Ministério do Turismo.

\subsection{PAPEL DAS POLÍTICAS PÚBLICAS PARA O DESENVOLVIMENTO DO TURISMO}

O papel das políticas públicas para o desenvolvimento do Turismo é de extrema importância por se tratar de instrumento de desenvolvimento da atividade, desenvolvimento este que se traduz na preocupação de um Turismo voltado para a responsabilidade dos destinos.

De acordo com a OMT (1999), as políticas de turismo precisam ser desenvolvidas observando o respeito pelo patrimônio artístico e natural das comunidades, de uma forma que permita a sobrevivência das tradições e o 
desenvolvimento sustentável. Deve-se, assim, evitar a padronização e o empobrecimento do local. Deste modo, cabe à política de turismo estabelecer metas e diretrizes as quais orientem o desenvolvimento sócio espacial da atividade, na esfera pública e até mesmo na esfera privada, já que na ausência da orientação política o turismo se desenvolveria de forma inapropriada, de acordo somente com iniciativas ou interesses particulares, esquecendo o interesse coletivo.

Seguindo essa percepção, ao adotar uma política para o turismo, o papel que o turismo viria a desempenhar na sociedade seria explicitado, bem como sua importância cultural, social e econômica para com as comunidades envolvidas, implicando uma tomada de posição, por parte do poder público, capaz de constituir uma orientação, uma direção, tanto para o setor público como para o setor privado.

Como resultado do fortalecimento das políticas públicas de turismo no século $X X$, alguns governos instituíram os primeiros organismos - de abrangências nacional ou internacional - especializados na promoção e no planejamento da atividade objetivando o monitoramento dos impactos negativos e a potencialização dos seus benefícios. Há várias estruturas organizacionais diferentes para o envolvimento do governo no turismo em países de todo o mundo. Como exemplos de organizações nacionais podem-se citar: Office Nacional du Tourisme, em 1910, na França; Comissaria Regia de Turismo, em 1911, na Espanha; Office Nacional Suisse du Tourisme, em 1917, na Suíça; Ente Nazionale per le Industrie Turistiche, em 1921, na Itália; Travel Association of Great Britain and Ireland, em 1927, no Reino Unido e instituições de abrangência internacional verificam-se também alguns exemplos, tais como: a Associação dos Albergues da Juventude, em 1909; a Federação Internacional das Agências de Viagem (FIAV), em 1919; a American Society of Travel Agency (ASTA), em 1930; a Internacional Air Transport Association (IATA) ${ }^{58}$, em 1944; a Associação Internacional de Hotelaria $(A I H)^{59}$, em 1946; e a União Internacional de Organismos Oficiais de Turismo (UIOOT), cuja criação remonta a 1925, quando ocorreu o Congresso Internacional das Associações Oficiais de Propaganda Turística (COOPER et al, 2007).

Nesse contexto, Hall (2004) se utiliza de uma citação importante de Mercer (1979) sobre a ligação da importância dada a um determinado assunto e a criação no

\footnotetext{
${ }^{58}$ Em substituição a Air Traffic Association, criada em 1919.

${ }^{59}$ Em substituição a Associação Internacional dos Hoteleiros criada em 1921.
} 
governo de departamentos ou seções e a de órgãos consultivos relacionados àquele determinado assunto:

\begin{abstract}
A criação de departamentos governamentais, seções ou órgãos consultivos totalmente novos dentro da administração existente é uma estratégia bem organizada pelo governo para demonstrar em alto e bom som que algo positivo está sendo feito com respeito a determinado problema. Além disso, como a burocracia do serviço público é inerentemente conservadora quanto à abordagem da delineação do problema e do modo de funcionamento preferido, (...) a reestruturação administrativa, juntamente com a legislação a ela relacionada, é quase sempre um indicador importante da pressão pública por ação e mudança. (MERCER, 1979, p.107 apud HALL, 2004 p. 196).
\end{abstract}

$\mathrm{Na}$ maioria das nações do ocidente desde o final da década de 1970, a tendência de privatizar e comercializar funções que antes eram desempenhadas pelo governo influenciou significativamente a natureza de vários tipos de envolvimento do governo federal no setor do turismo (HALL; JENKINS, 1995, apud HALL, 2004).

Segundo Davis et al (1993, p.24, apud HALL, 2004, p. 195), três razões econômicas fundamentais podem ser identificadas para essa tendência: "os governos estão interessados em fazer com que as empresas estatais dependam menos dos orçamentos públicos, em reduzir a dívida pública com a venda de bens e em elevar as eficiências técnicas pela comercialização." As próprias razões econômicas, no entanto, são encobertas por fundamentos políticos racionais pautados nas perspectivas filosóficas mais amplas referentes à questão de quais são os papéis adequados para o Estado e o indivíduo dentro da sociedade. A ideologia, assim, exerce um efeito prático na composição das instituições governamentais e suas tarefas (HALL, 2004).

Ademais, em todo o mundo existem diferentes estruturas organizacionais para 0 envolvimento do governo no turismo. As estruturas organizacionais utilizadas pelos governos desenvolvem-se ao longo do tempo em relação a vários fatores, os quais incluem além das filosofias políticas referentes ao papel apropriado do Estado, as "tradições nacionais da administração pública, a natureza do sistema político e os valores e interesses no processo burocrático". Na medida em que novas exigências e interesses, como preocupações ambientais, alcançam uma posição protuberante na agenda política, novos departamentos podem ser instituídos como parte do crescimento da atividade e influência notadamente do governo (HALL, 2004, p.196). 
O turismo passou a ocupar distintas posições nas estruturas administrativas governamentais em diferentes partes do mundo, como já foi exemplificado. Mesmo que o turismo seja muitas vezes considerado uma atividade com forte dependência do setor privado, "órgãos do governo em todos os níveis, desde o internacional a pequenas cidades, adotaram um papel progressivamente mais ativo no uso do turismo como instrumento de desenvolvimento" (SMITH, 1989, apud HALL, 2004, p.184). Isso se deve ao fato de características do turismo que já foram relatadas nesse trabalho - como, por exemplo, fonte de grande oferta de empregos. "Os órgãos governamentais atualmente divulgam o turismo como uma panaceia para o subemprego em áreas economicamente desfavorecidas" (SMITH, 1989, apud HALL, 2004, p.184). Dessa forma, o governo auxilia a modelar a estrutura econômica para o turismo, mesmo que fatores internacionais relacionados a taxas de câmbio, taxas de juros e confiança do investidor sejam cada vez mais importantes. Além disso, ele deve apoiar o fornecimento de infraestrutura e o atendimento a exigências educacionais para o turismo, necessita criar, também, o ambiente regulador no qual as empresas atuam e ainda desempenhar um papel ativo em divulgação e marketing (HALL, 2004).

Aliás, o turismo pode ser política e economicamente atraente para o governo, uma vez que pode proporcionar a impressão de produzir resultados a partir de iniciativas políticas em um curto período de tempo em relação a números de visitantes e/ou geração de empregos (HALL, 1998b apud HALL, 2004).

"Uma política nacional de turismo pressupõe uma tomada de posição, por parte do poder público federal, ante a atividade, tendo como base o território nacional, capas de estabelecer um norte, uma orientação tanto para o setor público como para o setor privado - incluindo-se setores de atividades que influem no desenvolvimento do turismo - no sentido de atingir os objetivos estabelecidos por essa política (sejam eles quais forem)" (CRUZ, 2002, p. 49).

Mesmo que possam existir variações de um local para o outro em termos do grau em que são aplicáveis, é possível identificar múltiplas funções do governo no turismo. Nesse sentido podemos citar a precursora da OMT, a União Internacional de Organizações Oficiais de Viagens (IUOTO, 1974), que ao debater o papel do Estado no turismo, identificou cinco áreas de envolvimento do setor público, quais sejam: coordenação, planejamento, legislação e regulamentação, empreendimentos e incentivo. Além do mais, a esses papéis podem-se adicionar duas outras funções: um papel de 
turismo social e outro, mais amplo, de proteção de interesses (HALL, 1994 apud HALL, 2004, p.185).

\subsection{HISTÓRICO DA GESTÃO FEDERAL DO TURISMO NO BRASIL}

Para uma melhor compreensão das Políticas de Turismo no Brasil, a autora realizou um levantamento histórico dos principais fatos ocorridos para a construção desta discussão.

Deste modo, o início do século XX foi marcado pela incorporação do turismo pelos brasileiros por meio do aumento das viagens de férias e das atividades de lazer, 0 que ocasionou o começo do fortalecimento desse fenômeno no país. Da mesma maneira que na Europa e nos Estados Unidos, inicialmente o turismo no Brasil foi praticado exclusivamente pelas elites, já que eram as únicas pessoas que tinham condições financeiras para o financiar. "Os principais destinos dos abastados turistas eram balneários e estâncias climáticas, termais ou hidrominerais, indicados para tratamentos de saúde e que posteriormente, se tornaram locais de jogatina" (BRASIL. UFRRJ, 2010 apud BORGES, 2013, p.96).

Posteriormente, as leis trabalhistas de 1940 e o desenvolvimento do setor automobilístico na década de 60 popularizaram o turismo na classe média, e, como consequência, impulsionaram o surgimento de infraestrutura e de serviços turísticos no Brasil.

Dessa forma, com o aumento do número de pessoas praticando o turismo, surge a demanda por intervenção estatal para ajustar imperfeições do mercado e coordenar a atividade, ou até mesmo para estimular enquanto atividade econômica. Como resultado, criam-se ações governamentais isoladas até se chegar a primeira efetiva Política Nacional de Turismo em 1966.

Nesse contexto, a estrutura de gestão pública do turismo no Brasil foi implantada de acordo com os interesses dos governos ao longo do processo histórico, iniciando-se a partir da década de 1930, com a criação do Departamento de Imprensa e Propaganda (que tinha uma agenda de turismo), passando pela década de 1960, com a criação da Empresa Brasileira de Turismo e do Conselho Nacional de Turismo (durante a ditadura militar) e chegando até 2003 com a criação do Ministério do Turismo. 
As primeiras ações tiveram a preocupação do turismo enquanto um instrumento para reforçar a imagem que a elite queria mostrar do Brasil nacional e internacionalmente. Essa intenção permaneceu até o final do período de ditadura militar (SANTOS FILHO, 2008). Já nos anos 90, devido ao fato que o país passava por profundas crises econômicas, o turismo começou a ser visto como ferramenta geradora de divisas, e teve esse enfoque refletido na criação do Ministério da Indústria, do Comércio e do Turismo.

Houve uma mudança de postura em relação à forma de se ver o turismo e, com isso, sua gestão em nível federal migrou para a pasta do Ministério do Esporte, que passou a ser Ministério do Esporte e Turismo, até chegar à criação de um ministério para tratar exclusivamente do assunto - o Ministério do Turismo - em 2003.

Assim, com a criação do Ministério do Turismo a gestão do setor passou a se desenvolver de forma mais complexa. Como explicitado no Plano Nacional de Turismo de 2007 (BRASIL, 2007), o Sistema de Gestão do Turismo envolve os três níveis de gestão administrativa. O Governo Federal, por meio do Ministério do Turismo, elabora as políticas, os programas, as ações, como também forma parcerias, e disponibiliza recursos de capital, de gestão e informações e orientações estratégicas. Na esfera estadual, as secretarias devem aperfeiçoar e ordenar as demandas do setor, além de priorizar as ações vindas das próprias Secretarias, agências ou similares instituições. Além disso, são responsáveis por formularem políticas próprias que traduzam as especificidades dos seus estados. E, finalmente, no âmbito municipal fica a responsabilidade de se estabelecer as políticas e as linhas gerais de ação turística de acordo com o seu domínio, sempre pautadas na sustentabilidade econômica, social, ambiental e cultural.

Borges (2013) considera que a narrativa da ação governamental do turismo pode ser dividida em quatro períodos, com no mínimo um marco institucional representativo em cada um, como mostrado na Figura 07 a seguir. 


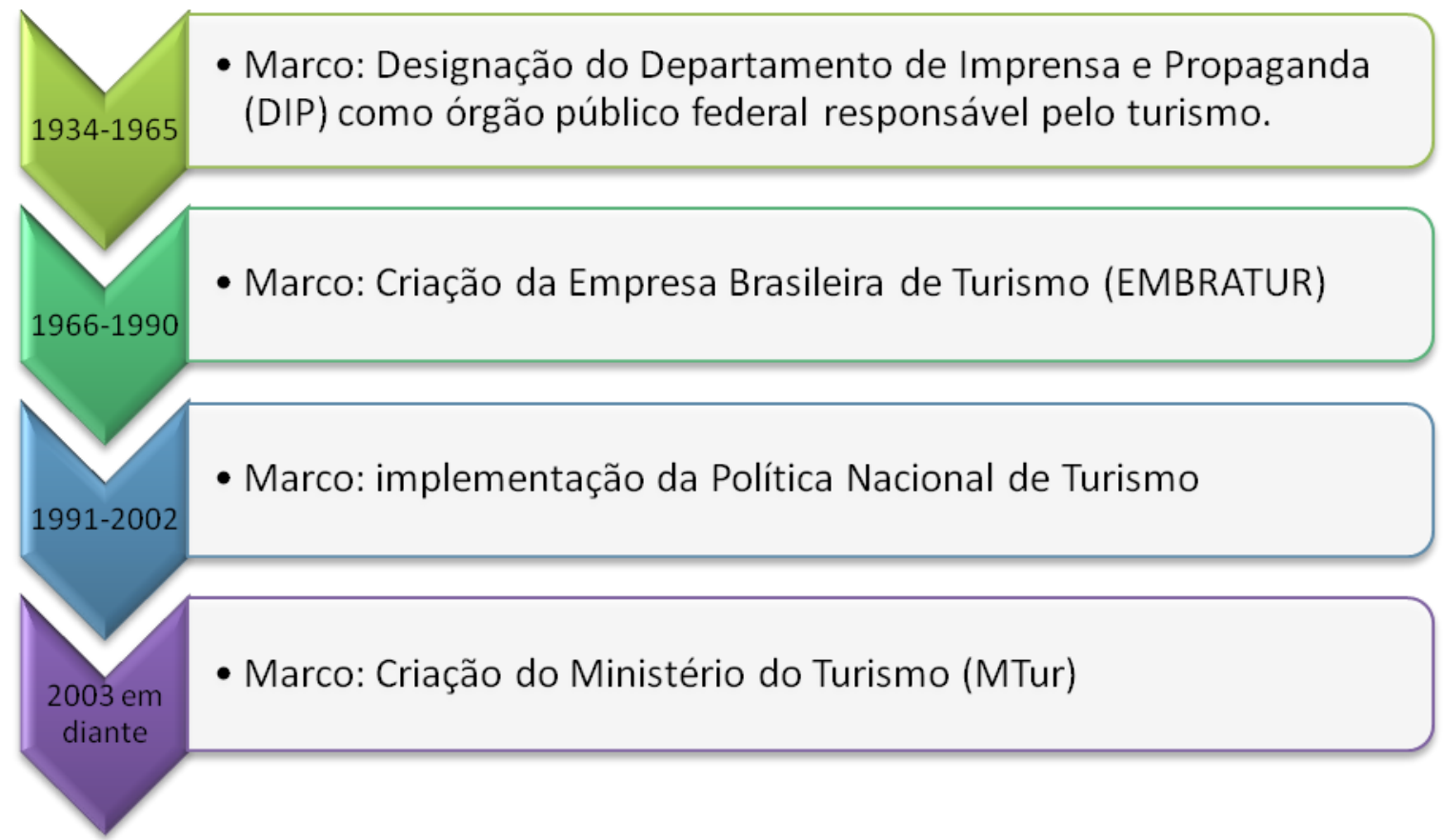

Figura 07 - Períodos da ação do Governo Federal sobre o Turismo Fonte: Adaptado de Borges (2013)

O período inicial (1934-1965) ${ }^{60}$ pode ser caracterizado por ações isoladas e desconexas em relação à criação de legislação - como decretos e decretos-lei - com o objetivo de regulação de atividades características de um setor ainda em seu início de desenvolvimento, principalmente a produção de documentos relacionados à regulamentação de agências de viagens e turismo. Cabe notar que até 1966 as ações governamentais brasileiras restringiam-se a aspectos somente parciais da atividade turística e que por esse motivo não eram reconhecidas oficialmente como políticas nacionais de turismo (CRUZ, 2002; BORGES, 2013).

Segundo Nagabe e Machado (2011), em 1934, a primeira referência oficial do governo federal em relação ao turismo trata-se de um acordo ${ }^{61}$ entre o Brasil e a Argentina para desenvolver o movimento turístico entre esses dois países. O Decreto libera o trânsito de veículos de turismo entre os dois países e extingue as taxas para esses turistas. Posteriormente, acordos semelhantes foram assinados com o Uruguai $(1937)^{62}$ e com o Chile (1952) ${ }^{63}$.

\footnotetext{
${ }^{60}$ Essa primeira fase da história das políticas nacionais de turismo no Brasil, segundo Cruz (2002), poderia ser chamada de "pré-história" jurídico-institucional das políticas nacionais de turismo.

61 Decreto no 24.393, de 13 de junho de 1934.

62 Decreto no 1.846/1937.

${ }^{63}$ Decreto № $31.536 / 1952$.
} 
Entretanto, o primeiro diploma legal referente ao turismo no Brasil foi o Decretolei 406 de 4 de maio de $1938^{64}$, que regulou o comércio de passagens aéreas, marítimas e terrestres, e operações de câmbio no país, ao vincular essas ações a uma prévia autorização do governo, e dispôs, também, sobre a entrada de estrangeiros no território nacional, os quais foram caracterizados pelo termo "turistas" (FERRAZ, 2001; CRUZ, 2002; BORGES 2013).

Como mostrado na Figura 07, o marco institucional desse primeiro período foi a designação do Departamento de Imprensa e Propaganda (DIP) como órgão público federal responsável pelo turismo. Esse órgão, que era diretamente ligado à Presidência da República, detinha o controle integral dos meios de comunicação no Brasil em 1937 e cuidava das pastas de imprensa, publicidade e propaganda, radiodifusão, cinema e teatro, diversões públicas, turismo, e cedia apoio financeiro a projetos culturais.

Em $1939^{65}$, foi criado dentro do DIP a "Divisão de Turismo", que ficou responsável pela promoção internacional e por organizar e fiscalizar os serviços turísticos, principalmente os de agenciamento. Segundo Santos Filho (2008, p.108), essa divisão tinha como uma de suas principais atividades "a promoção do Brasil no exterior, com a edição de uma diversificada folhetaria e criação de boletins informativos sobre o Brasil em vários idiomas e distribuídos em hotéis, consulados, embaixadas, navios e órgãos públicos no exterior". Já Cruz (2002) explica que a principal atribuição desse setor, na prática, era mesmo fiscalizar as atividades relativas às agências de viagens.

De qualquer forma, o mais importante a ser observado na criação da Divisão de Turismo está no fato de que esta foi o primeiro organismo oficial de turismo na administração pública federal ${ }^{66}$, e isto significou a "ampliação do universo de atuação do Estado, no que se referia à atividade turística” (CRUZ, 2002, p.44).

A partir de então, a atuação estatal no turismo esteve sob a responsabilidade dos mais diferentes setores da administração pública. Em 1945, a Divisão de Turismo foi transferida para o Departamento Nacional de Informações (DNI), o qual era subordinado ao Ministério da Justiça e Negócios Interiores. Permaneceu vinculada a este

\footnotetext{
${ }^{64}$ Regulamentado pelo Decreto 3.010 de 20 de agosto de 1938.

${ }^{65}$ Decreto-lei 1.915 de 27 de dezembro de 1939.
} 
departamento durante parte do ano de 1946, quando foi remanejada para o Departamento Nacional de Imigração, posterior Instituto Nacional de Imigração e Colonização (1946-1958), do Ministério do Trabalho, Indústria e Comércio (CRUZ, 2002).

Em 1958, o governo federal criou a Comissão Brasileira de Turismo (Combratur), subordinada diretamente à Presidência da República. Esta comissão tinha como finalidade coordenar, planejar e supervisionar a execução da política nacional de turismo, com o objetivo de facilitar o crescente aproveitamento das possibilidades do país, no que se refere ao turismo interno e internacional (CRUZ, 2002; SOLHA, 2005).

Contudo, esta Comissão não tinha uma estrutura adequada, pois não permitia realizar todas as atividades que Ihe eram incumbidas, e, por isso, foi extinta em 1961. Para sua substituição, em 1962, foi criada a Divisão de Turismo e Certames do Departamento Nacional do Comércio, do Ministério da Indústria e do Comércio (19611966). Essa divisão desempenhou uma relevante função, ao concretizar o lançamento das bases do turismo nacional, por meio de importantes atividades, tais como: a elaboração do calendário nacional de exposições; o lançamento do primeiro guia de turismo nacional; a elaboração de normas para o registro e a fiscalização das agências de viagem; e o início de parcerias com grupos estrangeiros para a construção de hotéis e instalação de empreendimentos turísticos no Brasil, com o intuito de promover, organizar e fiscalizar exposições, feiras e certames no território nacional (SOLHA, 2005).

Entre extinções e criações de órgãos, divisões e departamentos - de 1966 até 1990 - os assuntos relativos a turismo mantiveram-se continuamente subordinados ao Ministério da Indústria e do Comércio, até que neste último ano, com a reforma administrativa estabelecida pelo governo Collor de Mello (1990-92) e a extinção do referido ministério, passam a ser vinculados à Secretaria do Desenvolvimento Regional da Presidência da República (CRUZ, 2002).

Essas várias mudanças que a gestão do turismo passou pode ser interpretada de distintas maneiras. Sobre esse assunto pode-se verificar a opinião de Cruz, 2002:

Essa circulação da atividade turística por tão diversas esferas da administração pública conduz a diferentes interpretações. Uma delas está associada ao fato de o turismo nunca ter estado entre as prioridades das políticas federais de desenvolvimento, do que seria resultado a 'fraqueza política' do setor, traduzida na inconstância dos organismos oficiais encarregados da gestão da atividade". Ou ainda (...) "devido à atuação de grupos ligados à atividade, e à sua respectiva articulação com as diversas esferas do poder público". E conclui que algumas 
"teriam simplesmente decorrido de mudanças de governo, geralmente acompanhadas por reformas estruturais na máquina administrativa. (CRUZ, 2002, p. 45)

Beni (2006, p.21-22) corrobora com essa ideia ao afirmar que "o setor do turismo nunca esteve entre as prioridades das políticas públicas nos três níveis de governo". E acrescenta que essa inconsistência de vínculo dos órgãos oficiais de turismo igualmente se refletiu, em maior ou menor escala, tanto nos estados quanto nos municípios, os quais, também, vivenciaram numerosas concepções, extinções e recriações de organismos direcionados ao turismo. $\mathrm{E}$ adverte que, repetidamente, o órgão público de turismo tem servido de "moeda de troca" nos arranjos políticos da base de apoio do Legislativo e Executivo, fato que contribui, por exemplo, para a descontinuidade de gestão.

Para finalizar esse assunto dos vínculos dos órgãos de turismo, destacamos que depois de 1992 o turismo ganha status ministerial: Ministério da Indústria, do Comércio e do Turismo (1992-1998), Ministério do Esporte e Turismo (1998-2002), até chegar ao atual Ministério do Turismo - a partir de 2003.

Apesar dos decretos anteriores, a primeira ação do Governo Brasileiro, formalizada, que tratou de forma exclusiva da atividade turística foi um diploma legal, Decreto-lei 2.440 de 23 de julho de 1940. Ele dispunha sobre o funcionamento e atuação do agenciamento de viagens e turismo e, assim, criava condições oficiais para que os diversos agentes privados envolvidos com o turismo no país tomassem frente da organização da atividade, logo, que se instituísse, de fato, em um setor da economia, como em outros países já havia ocorrido e influenciasse de forma determinante no desenvolvimento do turismo de massa no Brasil (CRUZ, 2002).

Vale destacar que, segundo Ferraz (2001), o Governo Federal nessa época não tinha ainda a definição de sua atuação na área do turismo, pois não sabia se sua intervenção era uma ação de natureza promocional ou estrutural.

Ferraz (1992 apud CRUZ, 2002) destaca que de 1946 a 1958 nada aconteceu quanto à legislação da área, e por isso ele faz referência a esse período como "hiato jurídico-positivo". Essa lacuna foi interrompida com o Decreto 44.863 de 21 de novembro de 1958, o qual cria a Comissão Brasileira de Turismo (Combratur). Ela era subordinada diretamente à Presidência da República, composta por representantes do governo e de entidades não governamentais, com o objetivo de "coordenar, planejar e supervisionar a 
execução da política nacional de turismo", e assim, "facilitar o crescente aproveitamento das possibilidades do país, no que respeita ao turismo interno e internacional" 67 .

Nesse contexto, é importante ressaltar dois pontos da política de turismo que surgiram com a criação da Combratur. O primeiro seria que essa comissão foi um marco na história das políticas públicas brasileiras de turismo, visto que o dispositivo legal que aprova o seu regimento faz referência a uma política nacional de turismo até então nunca mencionada. Apesar dessa "política" não chegar a se efetivar ${ }^{68}$, as atribuições da Combratur demonstram uma transição de pensamento do governo brasileiro, o qual agora se apresenta mais preocupado com a expansão e com a melhoria da infraestrutura turística nacional, principalmente da rede hoteleira, no lugar da anterior exclusiva preocupação com a organização do setor - especialmente o de agenciamento (CRUZ, 2002).

O outro ponto de destaque tem relação com a composição da Combratur, que como já foi explicado anteriormente, incluiu a participação na comissão da iniciativa privada, como representantes de grandes empresas de hotelaria, transportes e de agências de viagens (AGUIAR, 2010, apud BORGES 2013).

É interessante salientar que em 1961, pela primeira vez, o território brasileiro foi separado em regiões, áreas e zonas turísticas para fins de planejamento e promoção. Entretanto, pelo que se pode constatar, essa divisão não foi utilizada (BORGES, 2013).

$O$ desenvolvimento do turismo no mundo somado às expectativas de uma atividade econômica promissora fomentou a construção de um órgão público nacional para atender às necessidades urgentes do setor. Deste modo, em $1966^{69}$, foi criada, sob o regime jurídico de empresa pública, a Empresa Brasileira de Turismo (EMBRATUR) marco institucional do segundo período da história das ações governamentais federais (1966-1990). A função inicial da EMBRATUR ${ }^{70}$ era de promover o desenvolvimento, a normalização e a regulamentação da atividade turística no Brasil - registrar, fiscalizar e incentivar a qualificação dos prestadores de serviços turísticos.

\footnotetext{
${ }^{67}$ Artigo $2^{0}$ do Decreto n.48.126, de 19 de abril de 1960 (In: Ferraz, 1992).

${ }^{68}$ Devido ao seu curto prazo de existência: 1958-1962.

69 Decreto-lei 55 de 18 de novembro de 1966: reformula a máquina administrativa estatal, pois define a política nacional de turismo, cria o Conselho Nacional de Turismo (CNTur) e a EMBRATUR.

${ }^{70}$ De acordo com o Decreto-lei 60.224/67, art. 20, cabe à EMBRATUR "estudar e propor ao CNTur os atos normativos necessários à promoção da política nacional de turismo e, bem assim, aqueles que digam respeito ao seu funcionamento.
} 
Ferraz (2001, p.34) considera o Decreto n55/1966 como o "termo inicial do direito econômico turístico" no país, uma vez que nele o governo reconheceu o turismo como setor gerador de renda e de desenvolvimento econômico. Assim sendo, para fomentá-la começou a conceder isenção e/ou redução fiscal para a construção e reforma dos meios de hospedagem no País, fato que iniciou uma fase de incentivos fiscais e financeiros $^{71}$ à atividade turística (FERRAZ, 2001; CRUZ, 2002; ARAÚJO; TASCHNER, 2012).

Nesse cenário, Araújo e Taschner (2012), faz uma análise do Decreto №. 55/1966, e corrobora com a ideia que as atividades turísticas começavam a ser entendidas como possuidoras de potencial para atenuar as diferenças regionais, especialmente, no campo econômico.

Cruz (2002) faz uma importante observação em relação ao Decreto-lei 55/66: nele o setor de turismo é equiparado a uma indústria, ao se usar a expressão "indústria do turismo". Assim, ressalta que esse termo possui um significado importante no desenvolvimento do setor no país, pois ao vinculá-lo dessa maneira recebe incentivos equivalentes àqueles destinados ao setor industrial. Todavia, para o contexto dessa pesquisa o uso da referida expressão é um dos maiores erros já realizados na gestão do turismo, pois anula a visão humana do fenômeno e destaca somente a visão econômica e exploratória.

A EMBRATUR foi criada em um contexto de ditadura militar e de grandes perspectivas econômicas, já que vivia-se o "milagre econômico" com ótimas perspectivas em relação aos negócios e à economia. Porém, ao mesmo tempo, vivia-se um período de grande repressão, censura e violência. Nesse cenário, segundo Santos Filho, a EMBRATUR foi criada com a atribuição de coordenar e estimular as atividades turísticas em território nacional, e, assim, combater no mundo internacional a ideia de ditadura assassina. $\mathrm{O}$ governo já vinha pensando na criação de um órgão para planejar e organizar o turismo no território nacional, e resolveu criar a EMBRATUR para então também fazer a contra propaganda da ditadura com o apelativo à mulher brasileira, 0 exótico e o erótico. O que pode significar que o turismo foi usado nesse período para camuflar a repressão ao povo brasileiro e ainda estabelecer uma forma ideológica de se enxergar a sociedade (SANTOS FILHO, 2006).

\footnotetext{
${ }^{71}$ Esses incentivos eram orientados pelo "Plano de Prioridade de Localização de Hotéis de Turismo" que vigorou até 1991 - Resolução CNTur № 31 .
} 
Em 1967, foi regulamentado ${ }^{72}$ o Sistema Nacional de Turismo com o objetivo de formular e executar a "política nacional", o que acarretou o aparecimento das primeiras propostas de planejamento turístico no Brasil. Esse sistema era composto pelo Conselho Nacional de Turismo (CNTur) ${ }^{73}$ - órgão formulador da política -, pela EMBRATUR incumbido da execução da política e incremento do turismo -, pelo Ministério das Relações Exteriores - responsável pela promoção do Brasil no âmbito internacional, por meio de suas tarefas diplomáticas - e ainda por outros órgãos delegados.

Em 1969, por meio da Resolução do CNTur no 71, o Plano Nacional de Turismo (Plantur) foi lançado, no entanto, ele não chegou a ser executado. Dois anos mais tarde, pela primeira vez, o turismo foi incluído em um plano econômico de governo. Neste mesmo ano, foi criado um fundo para o financiamento de "obras, serviços e atividades turísticas”, nomeado como Fundo Geral do Turismo (Fungetur). Seu objetivo principal era a ampliação da oferta de meios de hospedagem no Brasil. Além desse incentivo, os construtores de empreendimentos turísticos começaram, também, a ter benefícios fiscais. Conforme Aguiar (2010, p. 4, apud BORGES, 2013) explica, no final da década de 1960 já se observava no país uma "expansão de grandes empreendimentos de hospedagem e transporte aéreo internacionais e a difusão da padronização de pacotes de viagem por grandes operadoras de turismo". Ainda em 1971, a primeira edição do anuário estatístico da EMBRATUR foi lançada, fator que inaugura uma série de estudos econômicos sobre o turismo que perdura até os dias atuais.

O ano de 1972 merece destaque, pois a participação nas ações do turismo foi ampliada. Aconteceu "a primeira reunião oficial de turismo, com a atuação das secretarias estaduais e representantes de empresas regionais de turismo" (BRASIL, 2006, p. 45), o que marcou o começo da participação dos órgãos estaduais nas atuações do governo federal no turismo. Esse envolvimento ainda aumentou devido ao direito obtido pela EMBRATUR em 1973, por meio do Decreto-lei № 71.791/73, de celebrar convênios com municípios prioritários, definidos pelo CNTur.

\footnotetext{
72 Decreto-lei no 60.224/1967.

${ }^{73}$ Decreto-lei $n^{\circ} 60.224 / 1967$ determina as atribuições do CNTur, sendo uma delas "formular as diretrizes a serem obedecidas na política nacional de turismo". Apesar dessa atribuição, o Conselho dependia dos estudos e propostas da EMBRATUR para que pudesse exercer aquela prerrogativa. Fato que acaba conferindo à EMBRATUR um poder maior que o conferido ao CNTur, no que se refere à elaboração das políticas nacionais de turismo. E talvez um dos motivos que causou a extinção do CNTur em 1991.
} 
Um pouco depois, em 1975, novos incentivos, dentre eles a redução de imposto de renda, ficaram conferidos à atividade turística e novos critérios foram instituídos para o Fungetur por meio do Decreto-Lei ํㅜ 1.439/75.

Com o desenvolvimento do turismo no Brasil, a EMBRATUR começou a crescer em importância e em responsabilidades. Destarte, em 1976, a EMBRATUR teve seus objetivos ampliados e começou a demonstrar o início de uma preocupação socioambiental. Suas finalidades passaram a contemplar o estímulo à preservação do "ambiente natural e a fisionomia social e cultural dos locais turísticos e das populações afetadas pelo seu desenvolvimento". Quanto à forma de gestão territorial do turismo, houve também uma primeira ação no momento em que a instituição passa a diferenciar "Áreas Especiais de Interesse Turístico" e "Locais de Interesse Turístico". Nesse tema, começa a abarcar como sua responsabilidade a realização de levantamentos para a identificação de tais destinos, assim como a elaboração e atualização dos inventários turísticos.

Um ano depois, em 1977, a primeira "Política Nacional de Turismo" teria sido publicada pela EMBRATUR. Ela foi apresentada durante a II Reunião do Sistema Nacional de Turismo, e continha as seguintes diretrizes: "proteção ao patrimônio natural; divulgação e promoção dos valores culturais; incentivo ao turismo interno [e ao externo]; promoção; recursos humanos; apoio à entrada de divisas; apoio à hotelaria de turismo; apoio às agências de viagem." (ANGELI, 2003, p. 89 - 90).

A década de 1980 foi marcada pelo processo de abertura do regime político anterior. A consolidação e ampliação do desenvolvimento do turismo foram realizadas por meio de decretos e portarias. "Foi um período de transição, principalmente por conta da nova Constituição, que propiciou um momento de ampla discussão nacional” (BENI, 2006, p. 25).

Como afirma Beni (2006), as bases efetivas para o cenário de sustentabilidade ambiental e social foram lançadas nessa década com a Política Nacional do Meio Ambiente $^{74}$, com o SISNAMA - Sistema Nacional do Meio Ambiente, junto com a deliberação normativa da EMBRATUR que definia o turismo social. Pode-se afirmar que foi a década de início da incorporação das questões ambientais na formulação das políticas públicas.

\footnotetext{
${ }^{74}$ Fixada no art. 25 da Constituição Federal de 1988.
} 
Nesse sentido, destacamos que em 1985, a EMBRATUR junto com o Instituto Brasileiro de Desenvolvimento Florestal (IBDF), ao buscar aproveitar o potencial para o turismo das unidades de conservação brasileiras e produzir relativo ordenamento ao ecoturismo no Brasil, lançaram um projeto chamado "Turismo Ecológico", como novo produto turístico brasileiro. Basso (2007, p. 3 e 4, apud BORGES, 2013) nota que se trata do "primeiro projeto a abordar a atividade turística em área natural".

Em 1986, houve a liberação do mercado ${ }^{75}$ para o exercício e a exploração de atividades turísticas. Eles eram controlados desde 1976, e agora sem a necessidade de registro, houve uma consequente redução da clandestinidade e aumento do número de agências de viagens no país. Ao mesmo tempo, houve a criação do programa "Passaporte Brasil" para a promoção do turismo interno; e quanto ao turismo externo, a promoção do Brasil no exterior ganhava força com a criação da Fundação Nacional do Turismo (Funtur), que assumiu tal função. Destaca-se ainda que crianças, jovens, idosos e pessoas com deficiência também ganharam programas de incentivo para viajar pelo País (BENI, 2006; BORGES, 2013).

No mesmo ano, para seguir as diretrizes do "Plano Nacional de Desenvolvimento da Nova República: 1986- 89", foi organizada uma nova "Política Nacional de Turismo" ${ }^{76}$. Esse plano governamental previa reformas econômicas e combate à pobreza e inclusive assinalava o turismo como setor prioritário da economia, gerador de divisas, de empregos e de valorização dos patrimônios natural e cultural. Esse documento defendia a democratização do turismo "para faixas cada vez mais amplas da sociedade brasileira" como forma de preservar o "patrimônio cultural e natural do País" e também contribuir para diminuir as desigualdades (BRASIL, 1986, p. 5-7, apud BORGES, 2013).

Como Borges (2013) observa, uma das estratégias para o desenvolvimento do setor, que fica clara em tal documento, é a confiança no apoio aos complexos turísticos - tais como os implantados pelos megaprojetos. Vale ressaltar ainda que uma das metas estabelecidas por essa Política Nacional foi a formação de Conselhos Comunitários Municipais de Turismo, situação que faz muito sentido, pois reflete o sentimento de participação popular do período pós-ditadura militar (BRASIL, 1986).

\footnotetext{
${ }^{75}$ Pelo Decreto n⒉294/1986.

${ }^{76}$ Homologada pelo CNTur.
} 
Em seguida, em 1988, o turismo é citado na Constituição Federal em seu art. 180. Nele ficam atribuídas responsabilidades iguais a todos os níveis governamentais e ressalta a atividade como "fator de desenvolvimento econômico e social".

Como fechamento do segundo período da história das políticas públicas de turismo no Brasil, é adequado citar Aguiar (2010, p. 9), que faz um resumo do que esse período representou para o turismo nacional: "[...] da criação da EMBRATUR até fins da década de 1980, acompanhamos uma significativa complexificação do fenômeno turístico no Brasil". No entanto, Cruz (2002, p. 53) avalia as ações governamentais até então e afirma que "até meados da década de 1990, a política nacional de turismo reduz-se, na prática, à ampliação e melhoria da infraestrutura hoteleira”. Nesse sentido, Oliveira (2008, p. 179) também percebe a "falta de definições no ordenamento público desta atividade até os anos noventa, quando se começa, de fato, a coordenar e a monitorar, mesmo com inúmeras dificuldades, o desenvolvimento do turismo nacional" (BORGES, 2013)

Deste modo, Cruz (2005) afirma que foi no início dos anos 90 que houve uma retomada da discussão acerca das políticas públicas para o turismo no país, com ênfase na importância econômica da atividade. Assim, o turismo começa a se sobressair como política setorial. Nessa ocasião, a atividade turística começa a ser vista como "engendradora de processos de desenvolvimento regional e, consequentemente, como instrumento minimizador de (históricas) desigualdades regionais" (CRUZ, 2005, p.30). Existiram vários fatores que exerceram influência determinante para que isso acontecesse, dentre eles, especialmente, o crescente significado econômico do setor de serviços naquele período; a necessidade de diversificação das atividades produtivas brasileiras como forma de geração de divisas e empregos; a potencialidade natural turística do país - nesse caso ainda eram considerados somente os segmentos de solpraia e de natureza (como os ecossistemas da Amazônia e do Pantanal); a disponibilização de capitais estrangeiros para financiamento de projetos e, ainda, os posicionamentos público e privado favoráveis ao desenvolvimento da atividade.

O terceiro período da trajetória das ações governamentais no turismo inicia-se com a reestruturação da EMBRATUR, em 1991, e se finaliza em 2002, pois no ano seguinte houve a marcante criação do MTur.

Nesse período, dois marcos importantes no campo do turismo nacional podem ser identificados: a Lei 8.181 de 28 de março de 1991 e o Decreto no. 448 de 14 de 
fevereiro de 1992, que regulamentou a referida lei. A Lei 8.181/1991 ${ }^{77}$ definiu uma nova configuração na gestão pública do turismo no Brasil, e continuou o processo de empoderamento da EMBRATUR, que recebeu a denominação de Instituto Brasileiro de Turismo e assumiu a condição de autarquia especial vinculada à Secretaria de Desenvolvimento Regional da Presidência da República. Essa instituição passou a ter a finalidade de "formular, coordenar, e fazer executar a Política Nacional de Turismo", sendo assim, assumiu o papel que na prática já exercia (CRUZ, 2002, p.56).

Como consequência dessa atribuição, já no ano seguinte, as diretrizes para a Política Nacional de Turismo foram estabelecidas, e junto com ela o instrumento para operacionalizá-la, o Plano Nacional de Turismo (Plantur - 1992 a 1994). No entanto, assim como o Plantur de 1969, ele não chegou a ser colocado em prática (CRUZ, 2002; FRATUCCI, 2008). O plano almejava estimular o desenvolvimento regional, com base na parceria do setor público com o privado, e dessa forma diversificar a distribuição geográfica da infraestrutura concentrada no sul e no sudeste. Além disso, o Governo Federal demonstrou uma preocupação em aumentar a articulação entre os atores desses dois setores, assim como o intuito de envolver a sociedade civil no processo decisório, intencionado a atingir a democratização deste (ARAÚJO; TASCHNER, 2012).

Apesar disso, alguns programas de desenvolvimento turístico foram implantados durante esse período, como o Programa de Desenvolvimento do Turismo no Nordeste (Prodetur - NE). Este programa, criado em 1991, ${ }^{78}$ fornece crédito ao setor público por meio de financiamento do Banco Interamericano de Desenvolvimento (BID) e em seu início instituiu a política de megaprojetos turísticos no nordeste. Os estados possuem autonomia para elaborar projetos, por meio de agências de desenvolvimento. Entre os inúmeros projetos destacam-se aqueles previstos para o litoral nordestino como o Projeto Parque das Dunas - Via Costeira (Rio Grande do Norte), Projeto Cabo Branco (Paraíba), Projeto Costa Dourada (Pernambuco e Alagoas) e Projeto Linha Verde (Bahia), viabilizados pelos estímulos criados para o fomento do setor hoteleiro (CRUZ, 2002).

Vale ressaltar que o Decreto 448/92 apresentava uma visão diferenciada sobre o turismo expressada em suas diretrizes, as quais indicavam no seu artigo $2^{\circ}$ que a prática

\footnotetext{
${ }^{77}$ Transforma a EMBRATUR em autarquia e extingue o CNTur, sendo transferidas para a EMBRATUR todas as atribuições do conselho.

${ }^{78}$ Sua implantação foi iniciada em 1994, somente no nordeste, porém, em sua segunda fase o Prodetur foi expandido para as cinco macrorregiões brasileiras e funciona até o momento.
} 
do Turismo deveria ser uma "forma de promover a valorização e preservação do patrimônio natural e cultural do País" e que o objetivo final do desenvolvimento turístico deveria ser "a valorização do homem". Ao analisarmos essas diretrizes é possível indicar que houve uma mudança no significado do turismo no que diz respeito às políticas nacionais de turismo anteriores e que essa mudança estaria explicitada na substituição da ênfase no desenvolvimento para a ênfase na valorização e preservação do patrimônio natural e cultural do país e para a valorização do homem (CRUZ, 2002; BECKER 1996). Essa mudança provavelmente está associada aos debates emergidos da preocupação com a preservação do planeta que estavam em grande evidência na época e adentravam os discursos de diversas áreas, visto que o período de formulação do Decreto coincidiu com a preparação da Rio-92.

A saída do presidente da república Fernando Collor de Mello no final de 1992, redesenhou a estrutura administrativa mais uma vez. Foi instituído o Ministério da Indústria, do Comércio e do Turismo, por meio da Lei no 8.490 de 19 de novembro de 1992. Criou-se também a "Secretaria Nacional de Turismo e Serviços" para planejar as ações do turismo e a incumbência de executá-las coube à EMBRATUR. Foi criada ainda a "Câmara Setorial de Turismo" com o intuito de discutir e propor ações e se tornou a essência do planejamento desenvolvido posteriormente. Como forma de solucionar os problemas na gestão do turismo, a Câmara propunha a criação de um planejamento do turismo de forma nacional, com a definição clara de políticas para o setor (CARVALHO, 2009).

O ano de 1994 foi marcante para a área do turismo no que diz respeito à abertura do país para empreendimentos internacionais. Nesse ano foi autorizada a concessão de crédito e incentivos governamentais às empresas estrangeiras, com o objetivo de estruturar o país na área de meios de hospedagem, principalmente a região nordeste. Essas empresas estrangeiras ainda ganharam, posteriormente, o benefício de enviar seus lucros para o exterior sem pagar imposto de renda. Tudo isso, como observa Oliveira (2008, p.186 e 187, apud BORGES, 2013), foi determinante para as redes hoteleiras internacionais instalarem-se no Brasil. Essas medidas foram essenciais para o fortalecimento da implantação das "políticas de megaprojetos" na costa nordestina, que lembrando, já aconteciam desde a década de 80 , e contava com pesados investimentos estatais em infraestrutura e seguindo o modelo mexicano de "sucesso" de Cancun. 
A política de turismo no Brasil pós-redemocratização elegeu a incorporação dos princípios de descentralização governamental como melhor forma de gestão do turismo, por meio do fortalecimento das secretarias e órgãos estaduais e municipais e a delegação de atividades a entidades privadas, com a terceirização de serviços; tendo como pressupostos o desenvolvimento e a estabilização econômica do país (BENI, 2006).

Assim, em 1994, cria-se, baseado em metodologia da OMT, o Programa Nacional de Municipalização do Turismo (PNMT) ${ }^{79}$, com o intuito de realizar 0 planejamento participativo ao sensibilizar os atores locais para o envolvimento e execução de um planejamento local do turismo. Segundo Beni (2006), o principal objetivo era de "melhorar o produto turístico brasileiro por meio da conscientização dos municípios e de seus habitantes acerca dos benefícios econômicos que o turismo poderia aportar, bem como da descentralização das atividades de planejamento". As diretrizes do programa incidiam na descentralização da gestão do turismo; na identificação dos municípios brasileiros com potencial turístico; no oferecimento de orientação técnica e disponibilização de metodologias para que as comunidades planejassem e desenvolvessem o turismo sustentável; na sensibilização da sociedade para a importância do turismo e no fortalecimento das relações de parceria entre o poder público e a iniciativa privada (BENI, 2006; BORGES, 2013).

Ao mesmo tempo, esse programa buscava reduzir os desequilíbrios regionais sociais e econômicos - bem como elevar o bem- estar dos menos favorecidos, e possuía como princípios norteadores a sustentabilidade, a descentralização, as parcerias, a mobilização e a capacitação (ARAÚJO; TASCHNER, 2012, p. 81).

Apesar de resultados positivos, o PNMT apresentou alguns problemas estratégicos que acabou comprometendo o programa. Sobre esse assunto podemos citar Beni (2006), quem faz uma interessante análise:

Em que pesem os benefícios desse programa para o processo de sensibilização, conscientização e interiorização do turismo, chegando aos poucos estados aos resultados esperados de empreendedorismo e planejamento regional integrado, o modelo da OMT (...) apresentou, logo de início, uma falha estratégica na sua implantação. O modelo presumia o conhecimento prévio, por cada país, de seu espaço turístico nacional ou de sua imediata identificação, o que levaria o

\footnotetext{
${ }^{79}$ Implantado a partir de 1995 e reconhecido pela OMT como o "melhor exemplo latino-americano de turismo sustentável" em 1998 (SILVEIRA, 2003, p. 249).
} 
programa do RINTUR - Relatório do Inventário Turístico Nacional a ser a primeira providência tomada. Como isso não foi feito, queimou-se essa primeira etapa, e muitos municípios apresentaram-se como vocacionados para o turismo. Acrescentaríamos, ainda, o conflito entre objetivos e a própria proposta do PNMT em relação ao imenso espaço geográfico diferenciado do país (...) (BENI, 2006, p. 26).

Por outro lado, esse Programa foi um marco institucional na trajetória da política nacional de turismo com enfoque territorial e se transformou em uma espécie de movimento nacional, capaz de mobilizar, atuar, promover, unir pessoas e instituições, ideias e propósitos e produzir resultados. Tais resultados possibilitaram o alicerce para avançar e agir para a mudança. A experiência da municipalização permitiu ampliar a ação e acreditar na abrangência regional. O PNMT foi a semente para o Programa de Regionalização do Turismo, o qual ainda será explicado nesse capítulo.

Ainda em 1994, o então Ministério da Indústria, Comércio e Turismo lança uma Portaria $^{80}$ relacionada ao Ecoturismo, que indica um grupo de trabalho para propor uma política e um programa nacional sobre este segmento, como alternativa para o desenvolvimento sustentável. Esse assunto começou a ficar realmente em voga após a Rio-92, sendo apropriado pelo turismo principalmente pelo interesse no Turismo Ecológico. Inclusive, houve a formação de várias operadoras de turismo especializadas nesse segmento e o lançamento, por parte do governo, de programas como o "Programa Polos de Ecoturismo" - que levantava informações sobre oferta de ecoturismo no país e o "Programa para o Desenvolvimento do Ecoturismo na Amazônia Legal" (PROECOTUR) ${ }^{81}$ - que trabalhava a infraestrutura e abrangia as regiões da Amazônia Legal, Centro-oeste e Pantanal Mato-grossense (BASSO, 2007).

Alinhado a este último programa, podemos citar o programa "Parques do Brasil", que foi lançado no final da década pela EMBRATUR junto com o Instituto Brasileiro do Meio-Ambiente e dos Recursos Naturais Renováveis - IBAMA. Objetivava o uso do "potencial ecoturístico dos espaços naturais protegidos, a fim de gerar crescimento econômico e benefícios sociais nas diversas regiões do país, cujo principal e bemsucedido modelo é o do Parque Nacional do Iguaçu" (BENI, 2006, p. 28).

\footnotetext{
${ }^{80}$ Portaria Interministerial № 001, de 20 de abril de 1994.

${ }^{81}$ Segundo Beni (2006, p.27 e 28), foram utilizados recursos do BID e do BIRD. Foi executado em conformidade com as estratégias estabelecidas para a totalidade da região da Amazônia Legal, a qual tem como principal base o chamado ZEE - Zoneamento Ecológico Econômico - ferramenta de planejamento adotado pelo governo federal que objetiva a promoção do ordenamento do espaço amazônico em decorrência da questão ambiental na região. "Os investimentos voltaram-se concentradamente para a elaboração de projetos turísticos aliados à preservação ambiental".
} 
Vale ressaltar que, a partir de 1995, período do primeiro mandato do presidente Fernando Henrique Cardoso, começou-se a incentivar a vinda de cruzeiros marítimos para o Brasil, por meio de mudanças nas regras de cabotagem (Emenda Constitucional no7/95), o que contribuiu para o aumento do fluxo de turistas para o Brasil.

Em 1996, a "Política Nacional de Turismo - Diretrizes e Programas (19961999) ${ }^{82 "}$ foi lançada. Nela estavam inclusos as principais diretrizes, as estratégias e os programas do Governo Federal para o período, e os numerosos programas de infraestrutura básica e turística. Ela apresentava quatro macro estratégias, quais sejam: "Ordenamento, desenvolvimento e promoção da atividade pela articulação entre governo e a iniciativa privada"; "Capacitação de recursos humanos para o setor"; "Descentralização da gestão do turismo"; e "Implantação da infraestrutura básica e turística adequadas às potencialidades regionais" (BRASIL, 1996).

Essa política representou um marco na história do turismo no país, pois pela primeira vez o governo criou uma efetiva ferramenta de planejamento com roteiro de ações e compromissos explicitados, o que refletiu o destaque que as políticas de turismo começavam a tomar na agenda do governo brasileiro (OLIVEIRA, 2008; CARVALHO, 2000; CARVALHO, 2009). Além disso, possuía como um de seus pilares o "desenvolvimento sustentado" e tinha como objetivo principal a promoção e o incremento do turismo como fonte de renda, geração de emprego e desenvolvimento socioeconômico do país, além de dar continuidade à busca de incentivo à descentralização das ações e à valorização dos recursos naturais de cada região (BRASIL, 1996).

Solha (2005) destaca que nesse período o turismo começa a ser preocupação até mesmo da Câmara dos Deputados. Ela cria a "Subcomissão Permanente de Turismo" para discutir assuntos relacionados à área. Esta Subcomissão realizou, por exemplo, em 1999, o "I Congresso Brasileiro da Atividade Turística", o qual reuniu políticos, acadêmicos e profissionais do setor, e cujo resultado foi a Carta de Goiás Agenda Única do Turismo Nacional, a qual determinava diretrizes norteadoras das principais ações e medidas prioritárias para extinguir os gargalos do turismo no país.

No período dos dois governos do presidente Fernando Henrique Cardoso (1995-1998 e 1999-2002) os esforços para absorver no debate do turismo os diferentes

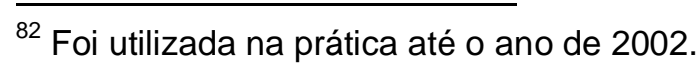


atores vindos das mais diversas esferas foram visíveis, inclusive da sociedade civil. Também foi destaque nessa ocasião, o empenho para o estabelecimento de fóruns com composição plural como, por exemplo, a Câmara Setorial de Turismo (1992-1996) e o Conselho Consultivo do Turismo Nacional (1998-2001) (CRUZ, 2002).

Destaca-se ainda que no final da década de 1990, o número de turistas no Brasil aumentou consideravelmente, fato este que pode estar relacionado, sobretudo, às mudanças, já explicitadas aqui, que ocorreram nesse setor durante esse período. Até 1996 o turismo era considerado uma atividade totalmente marginal, sendo que a inexistência de infraestrutura, combinada com equipamentos e serviços precários e, ainda, com os altos preços não permitiam o Brasil competir no mercado internacional. A definição de uma política de turismo e os investimentos foram fatores fundamentais para alcançar esse crescimento do fluxo internacional de turistas, inclusive pela conquista de novos mercados, como o MERCOSUL (CRUZ, 2002; SOLHA, 2005).

Para fechar a descrição dos acontecimentos desse $3^{\circ}$ período destaca-se a criação do "Ministério do Esporte e Turismo" no final de 1998 e a recriação do Conselho Nacional de Turismo (CNTur) em $2001^{83}$.

O quarto e último período, que se estende até a atualidade, iniciou-se no Governo Lula com a criação do Ministério do Turismo ${ }^{84}$ (MTur) em 2003. Considerado também um marco da política pública de turismo no Brasil, foi o primeiro ministério instituído exclusivamente para cuidar do turismo no país, e, assim, colocou o turismo em uma das dez prioridades do governo. O setor passa a contar com uma pasta própria, como também com estrutura e com orçamento específicos, consequentemente, cessa a divisão, com outros setores de atividades, da condução dos interesses particulares do turismo em nível nacional. Com isso, o orçamento destinado ao turismo cresce de forma considerável, principalmente com a destinação de emendas parlamentares. O MTur reforçou a adoção da gestão descentralizada e a utilização do turismo como ferramenta para o desenvolvimento regional e local de forma sustentável. O objetivo era desconcentrar a renda por meio da regionalização, interiorização e segmentação do turismo (BENI, 2006; CARVALHO, 2009).

\footnotetext{
${ }^{83}$ Porém, foi efetivamente reativado somente em 2003 como ainda será explicado.

${ }^{84}$ Lei no ${ }^{\circ} 10.683 / 2003$.
} 
Em função desse novo Ministério, o papel da EMBRATUR ${ }^{85}$ foi alterado para cuidar exclusivamente da promoção do Brasil no exterior e para centralizar a preparação de estudos e pesquisas com o intuito de nortear os processos de tomada de decisão, medir o impacto da atividade turística na economia nacional e formatar novos produtos e roteiros turísticos, enquanto que o MTur ficou com a atribuição de estruturar e promover o turismo nacionalmente (BENI, 2006).

Dessa forma, para que as atribuições do MTur fossem alcançadas, uma nova estrutura foi organizada da seguinte maneira: foi criada a Secretaria Nacional de Políticas de Turismo-SNPTur e a Secretaria Nacional de Programas de Desenvolvimento do Turismo - SNPDTur. A SNPTur elaborou a Política Nacional de Turismo e desenvolveu seu instrumento de execução, o Programa de Regionalização do Turismo, o qual articula organismos e instâncias nacionais e regionais, e promove a cooperação e o intercâmbio com os órgãos de administração nos três níveis - federal, estadual e municipal. Já a SNPDTur possui a função de subsidiar a formulação dos planos, programas e ações destinados ao desenvolvimento e ao fortalecimento do turismo nacional - imprescindíveis à consecução da Política Nacional de Turismo; de indicar diretrizes e prioridades para a aplicação do FUNGETUR; assim como de coordenar a formulação, apoiar e acompanhar os programas regionais de desenvolvimento do turismo que contenham objetivos de beneficiar as populações locais e o incremento da renda motivada pelo turismo nacional e internacional, além de coordenar a formulação, apoiar e acompanhar as ações de estímulo e fomento à mobilização da iniciativa privada, nacional e internacional, para sua participação ativa na implementação na Política Nacional de Turismo, entre outras funções (BENI, 2006).

Nessa reformulação da estrutura da administração pública federal do setor, ressalta-se ainda, o fato que o CNTur foi recriado e teve suas funções ampliadas. Ele passa a ser um órgão colegiado de assessoramento superior, integrante da estrutura básica do MTur e diretamente vinculado ao Ministro de Estado, com as funções de sugerir diretrizes, fornecer subsídios e colaborar para a implantação do PNT, ao emitir pareceres e recomendações sobre questões do turismo nacional, bem como ao propor normas que cooperem para a aplicação da legislação turística, a defesa do consumidor e o ordenamento jurídico do setor. Esse Conselho é composto por representantes dos

\footnotetext{
${ }^{85}$ Autarquia ligada ao MTur. Decreto no 4.898/2003.
} 
diversos ministérios e das entidades empresariais e de classe do sistema do turismo (BENI, 2006). Além desse órgão, cria-se o "Fórum Nacional de Secretários e Dirigentes Estaduais de Turismo" (FORNATUR), com ações apoiadas por câmaras temáticas e fóruns estaduais de turismo.

Ainda em 2003, o Plano Nacional do Turismo (PNT) - diretrizes metas e programas (2003-2007) foi lançado como ferramenta norteadora das atuações de gestão de turismo no Brasil. Reforçando a ideia de gestão descentralizada, sua finalidade foi a de agregar os atores envolvidos no planejamento do turismo e solidificar o MTur como articulador do processo de integração dos vários segmentos do turismo. Ao se analisar esse documento, percebe-se que ele oferece uma proposta para se repensar o modelo de desenvolvimento do turismo no país, com o intuito de melhorar a distribuição de renda entre as pessoas e os estados, promover a interiorização e a regionalização do turismo, incentivar os processos produtivos ambientalmente sustentáveis e aquecer a economia dos destinos por meio de relações comerciais justas, tudo isso subsidiado nos pilares do respeito aos valores éticos e culturais das comunidades.

Desde sua criação até os dias atuais a atuação do MTur encontra-se no lançamento e no desenvolvimento de programas e projetos nas mais diversas áreas do turismo, voltados para os múltiplos atores do setor. Todavia, vale lembrar que o MTur sofre com a descontinuidade de gestão, e com isso, várias de suas ações possuem caráter descontinuado, o que prejudica sua atuação de forma eficiente.

No ano de 2004, em substituição ao PNMT, cria-se o PRT - Programa de Regionalização do Turismo - Roteiros do Brasil como programa estruturante da gestão do turismo no país. O PRT foi criado para desenvolver o turismo fundamentado no desenvolvimento por regiões, ao passo que o PNMT, se baseava no desenvolvimento por municípios. A ideia parte das vantagens do processo de "clusterização" que gera benefícios até mesmo para os municípios que não possuem vocação turística, mas que estão localizados próximos a um destino turístico. Para melhor compreensão desse assunto, podemos citar Beni (2006):

Como abordagens de desenvolvimento que permeiam todo o planejamento estratégico de regiões turísticas, sendo complementares entre si e capazes de incrementar o poder de atração da destinação, assim como os benefícios trazidos pela atividade turística aos seus municípios têm-se a regionalização turística e o processo desclusterização da destinação. 
No que concerne à composição de experiências turísticas diferenciadas, a regionalização turística trata do espaço turístico de maneira dinâmica e flexível, sendo operacionalizada de duas formas: as multidestinações e as destinações múltiplas.

O processo de formação de multidestinações compreende o estabelecimento de parcerias entre destinações já existentes para a formação de circuitos, corredores, rotas e roteiros turísticos, sendo essencial à competitividade de qualquer destinação, pois reflete o estabelecimento de relações de competição e cooperação entre tais destinações, premissas de qualquer processo de clusterização (BENI, 2006, p. 125).

É relevante mencionar que a regionalização do turismo é um processo de organização territorial com a finalidade de orientar políticas públicas no que se refere ao planejamento, gestão, promoção e comercialização; e possui como objetivos: a promoção do desenvolvimento turístico sustentável de forma regionalizada no Brasil, e a diversificação, a ampliação e a estruturação da oferta turística brasileira.

Se a base do PNMT foi a formação de Conselhos Municipais de Turismo, a base do PRT é a institucionalização de "Instâncias de Governança Regional" e articulação direta com as regiões por meio dos interlocutores regionais. O Programa de Regionalização possui seu alicerce na gestão descentralizada do turismo. Um de seus pressupostos é a "sustentabilidade", que foi dividida em econômica, ambiental, sociocultural e político-institucional. Esse tema é destaque em um de seus treze cadernos orientadores, existindo um dedicado exclusivamente à "sustentabilidade" (BRASIL, 2004).

Em 2007, foi lançado o PNT (2007-2010) - Uma Viagem de Inclusão. Nele foi dado prosseguimento às ações desenvolvidas no PNT anterior (2003-2007), no entanto, agora com foco na expansão e no fortalecimento do mercado interno, com especial ênfase na função social do turismo, uma vez que se utilizou de uma abordagem inclusiva e de um discurso de "viagem para todos".

Os principais objetivos desse Plano foram: fortalecer o turismo interno; promover o turismo como fator de desenvolvimento regional; assegurar o acesso de aposentados, trabalhadores e estudantes a pacotes de viagens em condições facilitadas; investir na qualificação profissional e na geração de emprego e renda; e assegurar ainda mais condições para a promoção do Brasil no exterior. Uma de suas metas foi "estruturar 65 destinos turísticos com padrão de qualidade internacional". E para isso, o MTur começou a priorizar "65 Destinos Indutores do Desenvolvimento Turístico Regional". De qualquer 
maneira, apesar dessa priorização, as regiões turísticas restantes continuaram recebendo apoio do órgão.

Um ano depois, o turismo conseguiu mais uma conquista - a aprovação de uma lei que tramitava desde 1997 no Congresso Nacional, conhecida como "Lei Geral do Turismo" ${ }^{86}$ por abordar e regulamentar diversos assuntos relacionados ao turismo. Esse fato assinalou os progressos alcançados pelo setor nesse período. A lei em pauta dispôs sobre a Política Nacional de Turismo e definiu as atribuições do Governo Federal que passaram a abranger desde a definição dos PNT's, até o planejamento, o desenvolvimento, a regulamentação, a coordenação e a fiscalização do turismo. Determinou, também, que o papel do poder público é trabalhar o turismo como um "importante fator de desenvolvimento sustentável". Algumas empresas prestadoras de serviços turísticos - tais como agências de turismo, meios de hospedagem e transportadoras turísticas - passaram a ter o seu cadastro obrigatório no Ministério do Turismo e a seguir algumas regras específicas. Além disso, a lei regulou as linhas de crédito oficiais e o Fungetur, e, ainda, o "Sistema Nacional de Turismo" foi estabelecido, ficando composto pelo MTur, pela EMBRATUR, pelo CNTur e pelo Fornatur, além de regular as linhas de crédito oficiais e o Fungetur.

Sobre esse contexto, Araújo e Tascher (2012) dissertam que as atribuições do Governo Federal começam a passar uma sensação de segurança tributária e jurídica, uma vez que agora estava dentro de suas finalidades a ação de disciplinar os prestadores de serviços, com a garantia de estímulos financeiros provenientes do Governo Federal às pessoas físicas ou jurídicas, tanto do setor público quanto do privado, contando que desenvolvessem programas ou projetos turísticos.

Em 2010, o Decreto no 7.381/2010, que regulamentou a Lei no 11.771/2008, estabeleceu critérios de prioridade para aplicação dos recursos do Fungetur, dentre os quais se encontra "a prática do desenvolvimento ambiental sustentável". Outra resolução foi a obrigatoriedade de se revisar o Plano Nacional de Turismo a cada quatro anos. Apesar disso, após o término do PNT 2007-2010 o MTur demorou mais de 2 anos para lançar o terceiro Plano Nacional de Turismo ${ }^{87}$.

No ano de 2011 foram constituídos o Sistema Brasileiro de Classificação de Meios de Hospedagem (SBClass) e o Sistema Nacional de Registro de Hóspedes, de

\footnotetext{
${ }^{86}$ Lei no $11.771 / 2008$.

${ }^{87}$ PNT - O turismo fazendo muito mais para você - (2013-2016).
} 
maneira a regular os serviços de hotelaria no Brasil. Em 2012, o turismo teve participação ativa na Rio+20, até mesmo com a realização de um painel internacional dedicado ao assunto.

É importante citar que a partir de 2010 várias ações, em âmbito federal, estão sendo feitas, com o objetivo de atendimento das necessidades dos turistas dos megaeventos - Copa do Mundo FIFA 2014 e as Olimpíadas 2016, além das linhas de financiamento como a BNDES pré-copa. O último PNT (2013-2016) aborda esse tema e enfatiza que o legado dos megaeventos precisa ultrapassar a promoção dos atrativos turísticos nacionais, assim como a melhoria da infraestrutura e a qualidade dos serviços turísticos. Para isso, o MTur afirma que é necessário criar condições "para que tais eventos sejam capazes de consolidar o Brasil como um dos principais destinos turísticos mundiais" (BRASIL, 2013a, p.46).

Por último, com o intuito de apresentar uma melhor visualização de forma resumida desse histórico da gestão pública federal do turismo no Brasil, fez-se necessário o desenvolvimento de um quadro-resumo com as informações descritas anteriormente, Quadro 03, o qual será exposto em seguida.

Quadro 03 - Histórico da gestão pública do turismo no Brasil (1934 - 2013)

\begin{tabular}{|c|c|}
\hline ANO & ACONTECIMENTO \\
\hline 1934 & $\begin{array}{l}\text { Acordo entre Brasil e Argentina para desenvolvimento do } \\
\text { turismo entre os dois países, por meio do Decreto nํㄴ } 24.393 \text {, de } \\
13 \text { de junho de } 1934 \text {. }\end{array}$ \\
\hline 1938 & $\begin{array}{l}\text { Primeiro diploma legal, Decreto-Lei } 406 \text { de } 4 \text { de maio de } 1938 \text {, } \\
\text { que regulou o comércio de passagens aéreas, marítimas e } \\
\text { terrestres, e operações de câmbio no país, além de regular a } \\
\text { entrada de estrangeiros, caracterizados pelo termo "turista", em } \\
\text { território nacional. }\end{array}$ \\
\hline 1939 & $\begin{array}{l}\text { Primeiro marco institucional: criação da Divisão de Turismo no } \\
\text { Departamento de Imprensa e Propaganda (DIP). }\end{array}$ \\
\hline 1945 & $\begin{array}{l}\text { Transferência da Divisão de Turismo para o Departamento } \\
\text { Nacional de Informações (DNI), subordinado ao Ministério da } \\
\text { Justiça e Negócios Interiores. }\end{array}$ \\
\hline 1946 & $\begin{array}{l}\text { Transferência da Divisão de Turismo para o Departamento } \\
\text { Nacional de Imigração (posterior Instituto Nacional de } \\
\text { Imigração e Colonização) do Ministério do Trabalho Indústria e } \\
\text { Comércio. }\end{array}$ \\
\hline 1958 & $\begin{array}{l}\text { Criação da Comissão Brasileira de Turismo (Combratur), } \\
\text { subordinada diretamente à Presidência da República, com a } \\
\text { finalidade de coordenar, planejar e supervisionar a execução da } \\
\text { política nacional de turismo. }\end{array}$ \\
\hline 1962 & $\begin{array}{l}\text { Criação da Divisão de Turismo e Certames no Departamento } \\
\text { Nacional do Comércio, do Ministério da Indústria e do Comércio } \\
\text { em substituição à Combratur. }\end{array}$ \\
\hline
\end{tabular}




\begin{tabular}{|c|c|}
\hline ANO & ACONTECIMENTO \\
\hline 1966 & $\begin{array}{l}\text { Decreto-lei } 55 \text { de } 18 \text { de novembro de 1966: } \\
\text { - Criação da empresa pública Empresa Brasileira de Turismo } \\
\text { (EMBRATUR), considerada o marco institucional do segundo } \\
\text { período da história das ações governamentais federais; } \\
\text { - Definição da Política Nacional de Turismo; } \\
\text { - Criação do Conselho Nacional de Turismo (CNtur). }\end{array}$ \\
\hline 1967 & $\begin{array}{l}\text { Regulamentação do Sistema Nacional de Turismo, com o } \\
\text { objetivo de formular e executar a Política Nacional de Turismo. }\end{array}$ \\
\hline 1969 & $\begin{array}{l}\text { Resolução do CNTur no } 71 \text {, que lança o Plano Nacional de } \\
\text { Turismo (Plantur). }\end{array}$ \\
\hline 1971 & $\begin{array}{l}\text { Criação do Fundo Nacional de Turismo (Fungetur). } \\
\text { Lançamento da primeira edição do anuário estatístico da } \\
\text { EMBRATUR, que inaugura 1uma série de estudos econômicos } \\
\text { sobre o turismo que perdura até os dias atuais. }\end{array}$ \\
\hline 1972 & $\begin{array}{l}\text { Realização da primeira reunião oficial de turismo com a } \\
\text { atuação das secretarias estaduais e representantes de } \\
\text { empresas regionais de turismo. }\end{array}$ \\
\hline 1973 & $\begin{array}{l}\text { EMBRATUR passou a ter direito de celebrar convênios com } \\
\text { municípios prioritários. }\end{array}$ \\
\hline 1975 & $\begin{array}{l}\text { Decreto-Lei no } 1.439 / 75 \text {, que cria novos incentivos à atividade } \\
\text { turística, como a redução de imposto sobre a renda. }\end{array}$ \\
\hline 1977 & $\begin{array}{l}\text { Publicação da primeira Política Nacional de Turismo pela } \\
\text { Embratur. }\end{array}$ \\
\hline 1985 & $\begin{array}{l}\text { Lançamento do projeto "Turismo Ecológico", numa parceria } \\
\text { entre a EMBRATUR com o Instituto Brasileiro de } \\
\text { Desenvolvimento Florestal (IBDF), com o intuito de aproveitar o } \\
\text { potencial turístico das unidades de conservação brasileiras. }\end{array}$ \\
\hline 1986 & $\begin{array}{l}\text { Liberação do mercado para o exercício e exploração da } \\
\text { atividade turística. }\end{array}$ \\
\hline 1988 & $\begin{array}{l}\text { Promulgação da Constituição Federal, onde o turismo é citado } \\
\text { como "fator de desenvolvimento econômico e social" e são } \\
\text { atribuídas responsabilidades iguais a todos os níveis } \\
\text { governamentais. }\end{array}$ \\
\hline \multirow{3}{*}{1991} & $\begin{array}{l}\text { Reestruturação da EMBRATUR, com sua transformação em } \\
\text { autarquia, extinção do CNTur, sendo transferidas para a } \\
\text { EMBRATUR todas as atribuições do conselho. }\end{array}$ \\
\hline & $\begin{array}{l}\text { Lei } 8.181 / 1991 \text {, que definiu uma nova configuração na gestão } \\
\text { pública do turismo no Brasil. }\end{array}$ \\
\hline & $\begin{array}{l}\text { Criação do Programa de Desenvolvimento do Turismo no } \\
\text { Nordeste (Prodetur }-\mathrm{NE} \text { ). }\end{array}$ \\
\hline 1992 & $\begin{array}{l}\text { Instituição do Ministério da Indústria, do Comércio e do } \\
\text { Turismo, por meio da Lei no } 8.490 \text { de } 19 \text { de novembro de } 1992 \text {. }\end{array}$ \\
\hline \multirow{3}{*}{1994} & $\begin{array}{l}\text { Foi autorizada a concessão de crédito e incentivos } \\
\text { governamentais às empresas estrangeiras, com o objetivo de } \\
\text { estruturar o país na área de meios de hospedagem. }\end{array}$ \\
\hline & $\begin{array}{l}\text { Criação do Programa Nacional de Municipalização do Turismo } \\
\text { (PNMT). }\end{array}$ \\
\hline & $\begin{array}{l}\text { O Ministério da Indústria, Comércio e Turismo lança uma } \\
\text { Portaria relacionada ao Ecoturismo, que indica um grupo de } \\
\text { trabalho para propor uma política e um programa nacional } \\
\text { sobre este segmento, como alternativa para o desenvolvimento } \\
\text { sustentável. }\end{array}$ \\
\hline 1996 & $\begin{array}{l}\text { Lançamento da Política Nacional de Turismo - Diretrizes e } \\
\text { Programas (1996-1999) }\end{array}$ \\
\hline 1998 & Criação do Ministério do Esporte e Turismo. \\
\hline 2001 & Recriação do Conselho Nacional de Turismo (CNTur). \\
\hline 2003 & $\begin{array}{l}\text { Criação do Ministério do Turismo (MTur), da Secretaria } \\
\text { Nacional de Políticas de Turismo (SNPTur) e da Secretaria } \\
\text { Nacional de Programas de Desenvolvimento do Turismo } \\
\text { (SNPDTur), com a função de subsidiar a formulação dos } \\
\text { planos, programas e ações destinados ao desenvolvimento e }\end{array}$ \\
\hline
\end{tabular}




\begin{tabular}{|c|c|}
\hline \multirow[t]{4}{*}{ ANO } & ACONTECIMENTO \\
\hline & ao fortalecimento do turismo nacional. \\
\hline & $\begin{array}{l}\text { Criação do Fórum Nacional de Secretários e Dirigentes } \\
\text { Estaduais de Turismo (FORNATUR). }\end{array}$ \\
\hline & $\begin{array}{l}\text { Lançamento do Plano Nacional do Turismo (PNT) - Diretrizes, } \\
\text { Metas e Programas (2003-2007). }\end{array}$ \\
\hline 2004 & $\begin{array}{l}\text { Criação do PRT - Programa de Regionalização do Turismo - } \\
\text { Roteiros do Brasil, em substituição ao PNMT. }\end{array}$ \\
\hline 2007 & $\begin{array}{l}\text { Lançamento do Plano Nacional de Turismo (2007-2010) - Uma } \\
\text { Viagem de Inclusão. }\end{array}$ \\
\hline 2008 & Edição da Lei Geral do Turismo (Lei no 11.771/2008). \\
\hline 2010 & $\begin{array}{l}\text { Edição do Decreto } n^{0} 7.381 / 2010 \text {, que regulamentou a Lei } \mathrm{n}^{0} \\
11.771 / 2008 \text {, e estabeleceu critérios de prioridade para } \\
\text { aplicação dos recursos do Fungetur, dentre os quais se } \\
\text { encontra "a prática do desenvolvimento ambiental sustentável". }\end{array}$ \\
\hline $2010-2014$ & $\begin{array}{l}\text { Ações voltadas para os megaeventos, tais como obras de infra- } \\
\text { estrutura, qualificação e de estruturação. }\end{array}$ \\
\hline 2011 & $\begin{array}{l}\text { Constituição do Sistema Brasileiro de Classificação de Meios } \\
\text { de Hospedagem (SBClass) e do Sistema Nacional de Registro } \\
\text { de Hóspedes. } \\
\text { Avaliação do Programa de Regionalização do Turismo }\end{array}$ \\
\hline 2013 & $\begin{array}{l}\text { Lançamento do Plano Nacional do Turismo }(2013 \text { - 2016) - O } \\
\text { turismo fazendo muito mais pelo Brasil. } \\
\text { Lançamento das Diretrizes do Programa de Regionalização do } \\
\text { Turismo - PRT. }\end{array}$ \\
\hline
\end{tabular}

É válido ressaltar que não houve aqui a intenção de se esgotar as ações da gestão pública federal do turismo no Brasil. Buscou-se, na verdade, destacar as ações mais relevantes, para que, ao traçar um histórico desse assunto, fosse possível compreender o atual cenário das políticas públicas federais do país, assunto este que é base dessa dissertação. Tal histórico somado às bases teóricas até aqui construídas, foram fundamentais para ser possível iniciar as reflexões analíticas do trabalho, o que será feito nos próximos capítulos. 
It is not a bad conscience that we need to make progress, but positive experience, not the feeling of compulsion but that of responsibility.

$$
\text { Sost Trippendorf }
$$


Experiências precursoras e iniciativas em curso, em países que se tornaram referência na elaboração de documentos oficiais que constituem o arcabouço teórico do movimento do Turismo Responsável e/ou na prática de ações reconhecidamente de sucesso, bem como o Código de Ética Mundial para o Turismo fornecem os elementoschave para a caracterização de políticas sob a ótica da responsabilidade e, portanto, embebidas na ideia do TR. Ou seja, o estudo das políticas já criadas sob a ótica do Turismo Responsável oferece princípios norteadores para a análise de programas e projetos do MTur que, apesar de não terem sido intituladas como de TR, sob o guardachuva deste conceito, podem sinalizar uma consciência e uma tendência para a promoção responsável do turismo no Brasil.

O levantamento bibliográfico e documental realizado para o desenvolvimento desta pesquisa levou à escolha de dois países por apresentarem o maior repertório consolidado sobre o assunto, tendo subsidiado a criação de políticas públicas estratégicas de TR nos respectivos países. São eles: África do Sul e Gâmbia.

A escolha da África do Sul deu-se por ter sido a precursora em políticas públicas de Turismo Responsável e por fornecer a maior quantidade de documentos relacionados ao tema, como foi descrito anteriormente nesse trabalho. Já a seleção de Gâmbia, foi devido ao fato de ter sido um dos primeiros países que criou uma Política Nacional de TR, já em 2002, e por ser também um país que busca a inclusão social e melhores oportunidades para a população por meio do desenvolvimento do turismo, assim como o Brasil.

A seguir será exposta a análise dessas políticas mencionadas para que delas, somadas à Declaração da Cidade do $\mathrm{Cabo}^{88}$, possam ser retirados os elementos para a análise final dessa pesquisa - quando as iniciativas do MTur serão analisadas sob a ótica do Turismo Responsável.

\subsection{POLÍTICA PÚBLICA DE TURISMO RESPONSÁVEL NA ÁFRICA DO SUL}

A República da África do Sul é um país localizado no extremo sul do continente Africano, com população acima de 52 milhões de pessoas. Em meio a todos os documentos publicados pelo Governo Federal desse país destaca-se como mais

\footnotetext{
${ }^{88}$ Cape Town Declaration on Responsible Tourism, 2002.
} 
adequado para a nossa análise a publicação intitulada como "National Responsible Tourism Development Guidelines for South Africa", visto que é o documento que apresenta as diretrizes para o desenvolvimento da política pública de TR, e assim, é a base do desenvolvimento das estratégias de turismo do país. Como o que importa aqui é verificar os princípios, diretrizes e elementos-chave da responsabilidade nas políticas do setor, o documento em pauta apresenta-se suficiente e adequado aos objetivos dessa pesquisa.

Ele apóia-se nas conclusões e nas propostas do White Paper de 1996, que apresentou a visão de Turismo Responsável como um caminho para o desenvolvimento do turismo na África do Sul, e é referenciado no Plano Nacional de Turismo Sul-Africano. Apresenta o Turismo Responsável como estratégia de atuação para o setor no país e orienta para a criação de iniciativas que levem ao desenvolvimento sustentável do turismo.

O documento é dividido em três dimensões nomeadas de "Princípios Norteadores" ("Guiding Principles"), as quais são subdividas em "Objetivos e Indicadores" ("Objectives and Indicators"). Para cada objetivo tem-se a definição de vários indicadores, que para o presente estudo serão chamados de "premissas", já que indicadores possuem relação com dados matemáticos, em abordagem quantitativa, que não é o caso dessa pesquisa. A Figura 08 ilustra a estrutura do documento para que seja mais bem visualizada:

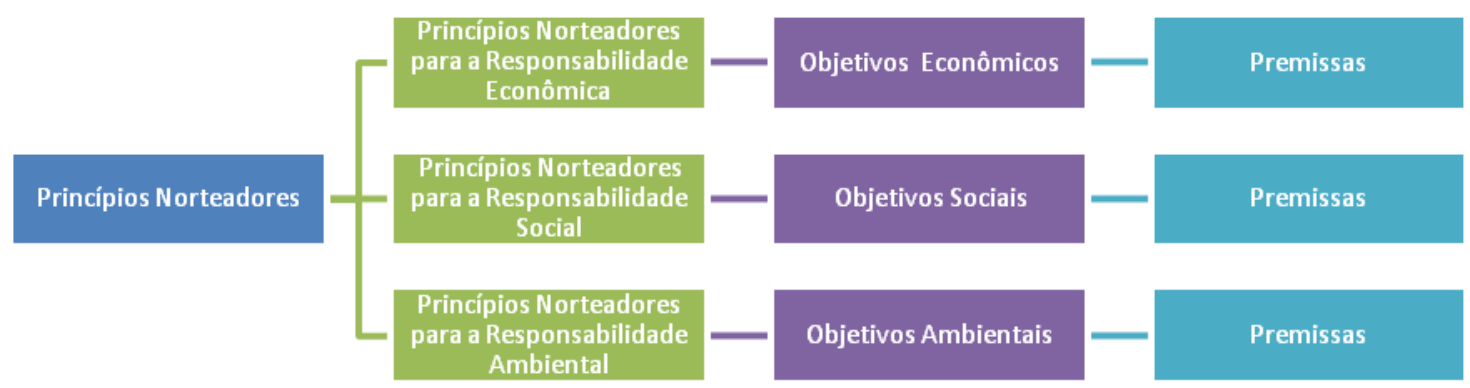

Figura 08 - Estrutura do Documento da África do Sul

Fonte: Criado a partir do "National Responsible Tourism Development Guidelines for South Africa", ÁFRICA DO SUL, 2002.

Dessa maneira, ao analisar o documento, é possível notar que para o desenvolvimento do TR, a África do Sul considera três linhas de ação - ou, como aqui será adotado, "dimensões" da responsabilidade - elas são: 1) Responsabilidade 
Econômica; 2) Responsabilidade Social; e 3) Responsabilidade Ambiental. Os objetivos e as premissas determinados para cada dimensão serão descritos e organizados, nessa pesquisa, de acordo com a divisão dessas linhas de ação/dimensões.

Primeiramente, para cada dimensão há uma introdução com a evidência de princípios que a ela estão relacionados. A primeira dimensão tratada no documento é a da Responsabilidade Econômica. A seguir, será explicada em uma análise a qual abordará suas principais características e seus princípios norteadores.

1) Responsabilidade Econômica: As Diretrizes Nacionais de Desenvolvimento do Turismo Responsável para a África do Sul deslocam o olhar tradicional do turismo, da preocupação exclusiva com o aumento do volume de chegadas internacionais e ganhos totais em moeda estrangeira, para o fomento do empreendedorismo local e de oportunidades para os historicamente desfavorecidos, para a redução da pobreza, a geração de empregos e o desenvolvimento do mercado de trabalho e da economia local. $O$ documento aponta, inclusive, que o mercado formal de turismo oferece oportunidades para o mercado informal, como se pode verificar no trecho a seguir:

(...) O foco em um mercado mais restrito tem reduzido o potencial da indústria para gerar empreendendorismo e criar novos serviços, como entretenimento local e artesanato, e para controlar o desenvolvimento econômico local. $\mathrm{Na}$ realidade, o setor de turismo formal cria mais oportunidades para o setor informal. (ÁFRICA DO SUL, 2002, p. 1) ${ }^{89}$.

A partir da publicação das diretrizes, a África do Sul começa a trabalhar na maximização dos benefícios que o turismo pode trazer para a economia local, especialmente na diversificação de produtos e serviços turísticos relacionados à vocação turística principal do país. Ou seja, os empreendimentos turísticos da região podem se beneficiar da criação de serviços e produtos complementares e tal demanda pode representar uma oportunidade para as populações tradicionalmente menos favorecidas, como comunidades rurais e as em situação de pobreza, que podem se

\footnotetext{
${ }^{89}$ Texto original: "(...) The focus on a narrow market has reduced the potential of the industry to spawn entrepreneurship and to create new services, like local entertainment and handicrafts, and to drive local economic development. In fact, formal tourism sector provides major opportunities for the informal sector." (ÁFRICA DO SUL, 2002, p. 1)
} 
tornar fornecedoras destes produtos e serviços turísticos, como pequenas hospedagens, restaurantes de cozinha local, guias de turismo, artesanato, entre outros. Essa colocação é comprovada no fragmento a seguir:

\begin{abstract}
O Livro Branco ("White Paper") identificou um conjunto amplo de oportunidades para os grupos historicamente prejudicados que vai de hospedarias, tabernas ("shebeens") e restaurantes de culinária local, passando por serviços de guia turístico, música, dança e contadores de história, artes e ofícios, caça e medicina tradicionais, até lavanderias, serviços de jardinagem e agricultura especializada. O turismo oferece oportunidades particulares ao desenvolvimento econômico local em áreas rurais, onde ele pode fornecer às pessoas alternativa ao deslocamento aos centros urbanos (ÁFRICA DO SUL, 2002, p. 1-2, tradução nossa). ${ }^{90}$
\end{abstract}

Além disso, é reconhecida a necessidade de o turismo estar relacionado com mercados e demandas, pois seu desenvolvimento é dependente do interesse de consumo dos seus visitantes. Esse ponto é explicado da seguinte forma:

\begin{abstract}
O turismo deve ser orientado ao mercado. Se os processos de desenvolvimento comunitários e turísticos não são planejados, implementados e gerenciados conforme as demandas do mercado, um número elevado de sul-africanos, especialmente os pobres, irão deparar-se não somente com oportunidades "perdidas", mas também com a dura realidade dos produtos fracassados ou de baixo desempenho, os quais os turistas não demandam. A experiência africana de turismo cultural precisa estar entrelaçada com o produto turístico sul-africano predominante. $^{91}$ (ÁFRICA DO SUL, 2002, p.2, tradução nossa)
\end{abstract}

São preocupações do desenvolvimento econômico responsável do turismo na África do Sul: reduzir a saída (ou fuga, perda) dos ganhos financeiros gerados pelo turismo do país - sejam eles advindos da visita do turista nacional ou internacional para economias externas, manter o capital no mercado local e aumentar a integração dos atores da cadeia produtiva da área. Acredita-se, por exemplo, que adquirir os

\footnotetext{
${ }^{90}$ Texto original: "The White Paper identified a wide range of opportunities for historically disadvantaged groups ranging from small guesthouses, shebeens ${ }^{90}$ and restaurants with local cuisine, through community tour guiding, music, dance and story-telling, arts and crafts, traditional hunting and medicine to laundry, gardening and speciality agriculture. Tourism provides particular opportunities for local economic development in rural areas where it can provide people with an alternative to moving to urban areas". (ÁFRICA DO SUL, 2002, p. 1-2)

${ }_{91}$ Texto original: "Tourism must be market related. If community-based and other tourism development processes are not planned, implemented and managed according to market demands then far too many South Africans, especially the poor, are facing not merely "missed" opportunities, but the hard realities of failed or under-performing products to which tourists simply do not come. The African cultural tourism experience needs to be woven into the fabric of the mainstream South African tourism product". (ÁFRICA DO SUL, 2002, p.2)
} 
insumos para os produtos e serviços turísticos localmente, seja uma forma de manter a economia local aquecida e de seus ganhos serem revertidos em benefícios para as comunidades locais:

\begin{abstract}
Reduzir a fuga de capital das áreas locais e ampliar a integração trarão significativo desenvolvimento econômico e contribuirá para a diversidade econômica local. De maneira similar, o desenvolvimento de produtos complementares fortalecerá a economia e as empresas locais; grupos de empresas consolidadas trabalhando conjuntamente podem fazer diferença significativa. Integração econômica robusta em nível local foi identificada no Livro Branco como um fato crítico de sucesso da economia local (ÁFRICA DO SUL, 2002, p. 2, tradução nossa). ${ }^{92}$
\end{abstract}

Ademais, a África do Sul adota a política de Fair Trade no marketing de seus produtos turísticos e conta com a atuação da IUCN South Africa Fair Trade in Tourism. Dessa forma busca incentivar os turistas a comprar produtos comprovadamente benéficos para as comunidades locais. "It is a good example of a responsible tourism marketing association with a vision of just, participatory and ethical tourism that provides meaningful benefits to hosts and visitors alike." (ÁFRICA DO SUL, 2002, p. 2).

Assim, dentro da perspectiva de responsabilidade econômica explanada anteriormente, as diretrizes para o desenvolvimento do TR na África do Sul são apresentadas separadas em quatro objetivos, e estes apresentam suas premissas em tópicos. São cinco objetivos estipulados para a realização da responsabilidade econômica no turismo, quais sejam: a) avaliar os impactos econômicos como um prérequisito para o desenvolvimento do turismo; b) maximizar os benefícios econômicos locais - aumentar a integração dos atores econômicos locais e reduzir as fugas de capital; c) garantir que as comunidades estejam envolvidas e se beneficiem com o turismo; d) marketing \& desenvolvimento de produtos; e) negócios equitativos. A seguir serão descritas, resumidamente, as premissas de cada objetivo, que foram divididos da forma como é feita no próprio documento.

\footnotetext{
92 Texto original: "Reducing economic leakages from the local area and increasing linkages will bring significant local economic development and assist in local economic diversification. Similarly the development of complementary product will strengthen the local economy and local enterprises, groups of established enterprises working together can make a significant difference. Strong economic linkages at the local level were identified in the White Paper as a critical success factor in the local economy" (ÁFRICA DO SUL, 2002, p. 2).
} 
a) "Avaliar os impactos econômicos como um pré-requisito para o desenvolvimento do turismo" por meio da diminuição dos impactos da sazonalidade com o desenvolvimento de novos produtos, ao se identificar e estimular respostas comerciais para o novo mercado formado pela ascendência econômica da população local historicamente desfavorecida, reconhecer a herança cultural para além do valor econômico, realizar avaliações de mercado e de viabilidade financeira antes de levantar expectativas e, com isso, evitar expor comunidade e empresários locais a investimentos de risco, estimular e manter a diversidade econômica dos destinos turísticos e evitar a dependência exclusiva destas áreas em relação ao setor;

b) "Maximizar os benefícios econômicos locais" - aumentar a integração dos atores econômicos locais e reduzir as fugas de capital por meio, entre outros, de: incentivo à elevação e à atualização de padrões de serviços, especialmente de pequenas, médias e microempresas empreendedores emergentes, incentivo à formalização do mercado informal, suporte às comunidades locais, aos artesãos e novos empreendedores no desenvolvimento de seus produtos, cooperação com empresas locais de outros setores, dar oportunidade aos clientes/ visitantes de comprar artesanatos e produtos típicos locais;

c) "Garantir que as comunidades estejam envolvidas e se beneficiem com o turismo", por exemplo, ao considerar a garantia de empréstimos para projetos promissores das comunidades ou com empreendedores emergentes e fornecer marketing, treinamento e suporte gerencial; fomentar o desenvolvimento de produtos turísticos de base comunitária, estimular a inovação dos roteiros turísticos, para isso, incluir, por exemplo, a visita à "shebeens", museus locais, lojas de artesanato e restaurantes étnicos locais;

d) "Marketing e desenvolvimento de produtos": considerando que a falta de acesso ao mercado é uma das principais restrições ao crescimento de novas empresas, destacou-se que esse item deve ser realizado por meio da divulgação de informações sobre os serviços e atrações locais previstos nas comunidades locais, e, ao mesmo tempo, pelo incentivo de seus clientes (pessoas físicas e operadores) a usá-los; considerar a publicidade, o marketing e a promoção, de forma cooperativa, de novos e emergentes produtos e atrações; certificar-se de que a apresentação visual do produto inclui elementos culturais locais e enfatiza a 
riqueza do produto complementar local; apreciar o desenvolvimento e a comercialização de produtos turísticos de comércio justo (Fair Trade); fomentar o desenvolvimento de oportunidades de acesso para todos os visitantes e potenciais visitantes, independentemente de suas condições físicas ou mentais. Nesse assunto destaca-se a citação seguinte: "As autoridades públicas e as empresas precisam entender e abraçar os incentivos financeiros que o aumento da acessibilidade vai gerar, e a imagem positiva que 'o acesso a todos' irá proporcionar." (ÁFRICA DO SUL, 2002, p. 4)

e) "Negócios equitativos", como, por exemplo, o pagamento de preços justos por serviços locais comprados ou inclusos nos pacotes dos principais roteiros, desenvolvimento de sistemas transparentes de compartilhamento dos benefícios do turismo por meio de contratos equitativos, reconhecimento de que a empresa pode desempenhar um papel significativo no aumento das habilidades $e$ capacidade da comunidade local e de que a empresa se beneficiará disso, além, de investimento no pessoal local oferecendo mais do que apenas um salário "qualidade é dependente de pessoal bem motivado." (ÁFRICA DO SUL, 2002, p. $5)$.

A Figura 09, mostrada a seguir, resume de forma esquemática os cinco objetivos da África do Sul para a responsabilidade econômica, que foram descritos anteriormente. 


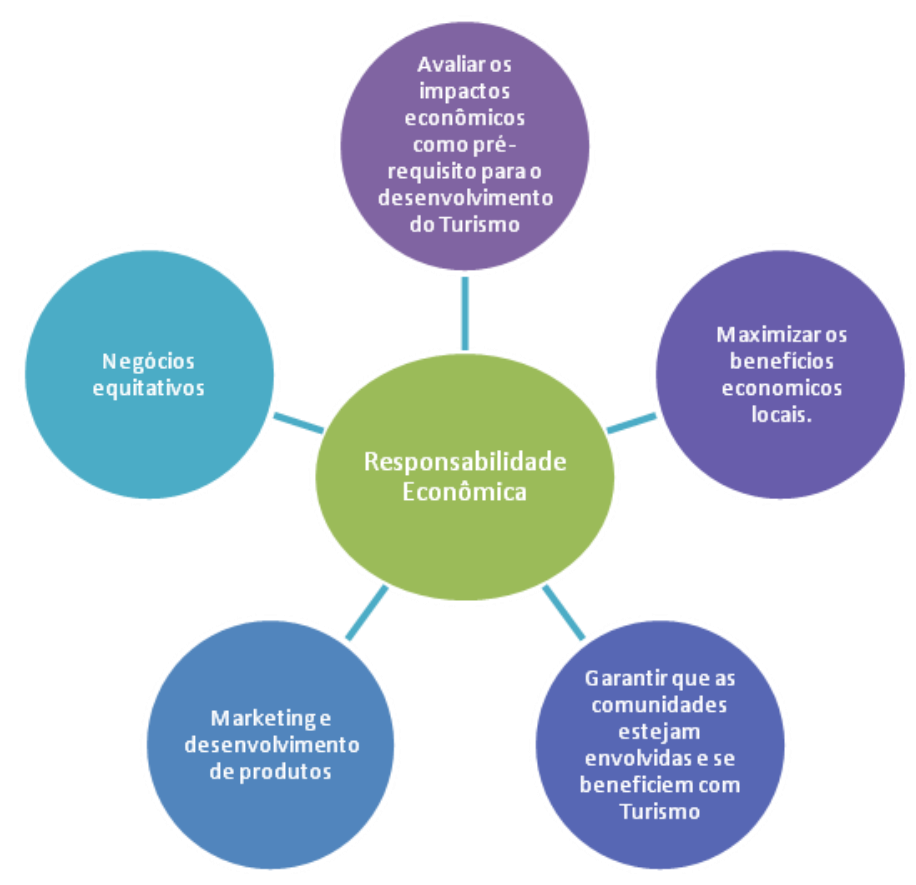

Figura 09 - Objetivos da Responsabilidade Econômica da África do Sul

Fonte: Criado a partir do "National Responsible Tourism Development Guidelines for South Africa".

2) Responsabilidade Social: Dentro do eixo de responsabilidade social, um dos objetivos do governo da África do Sul é garantir que todos os cidadãos tenham igual acesso aos serviços de turismo, tanto como consumidores quanto como fornecedores. Para isso, as diretrizes de Turismo Responsável da África do Sul afirmam que, atualmente, muito pouco dos benefícios do turismo são revertidos para as comunidades locais das áreas visitadas e que boas relações de vizinhança e com os historicamente desfavorecidos constroem uma boa noção de negócios.

O documento aponta que as empresas e comunidades precisam identificar maneiras de fornecer uma gama de experiências de turismo suficientemente ampla para se tornar acessível ao sul-africano médio. Ao possuir como princípio norteador a máxima de Batho Pele, (coloca as pessoas em primeiro lugar - cada um e todos devem ter sua justa parte ${ }^{93}$ ). há a ideia de transformar todos os sul-africanos, inclusive e especialmente os trabalhadores empregados na linha de frente do turismo, em "turistas em casa". O Turismo Responsável é citado como uma forma de combater a exclusão social, sendo possível contribuir, inclusive, para a diminuição dos índices de criminalidade, muitas vezes, relacionados ao ou gerados pelo turismo.

\footnotetext{
${ }^{93}$ Batho Pele: Putting People First - One and all should get their fair share.
} 
A exclusão social tem contribuído para o foco historicamente estreito, míope da indústria na África do Sul. O Turismo Responsável permite e estimula as comunidades locais historicamente desfavorecidas a terem acesso a mercados lucrativos de turismo. (ÁFRICA DO SUL, 2002, p. 5)

(...) Os tours de township demonstram que onde guias locais atuam como anfitriões, e onde há claros benefícios tanto para as comunidades como para os empreendedores historicamente desfavorecidos, os turistas podem ter uma boa experiência e a garantia de sua segurança. (ÁFRICA DO SUL, 2002, p. 6)

São considerados os custos da oportunidade de criação de parques nacionais e o subsequente acesso reduzido aos recursos naturais e culturais, e o fato de que as comunidades carentes dessas áreas não perceberam ou receberam quaisquer benefícios diretos significativos da mudança no uso da terra advindos da conservação e do turismo. "As comunidades devem ser empoderadas para participar da gestão de áreas, para que possam ter a palavra na distribuição dos benefícios e da utilização sustentável de seu meio ambiente." (ÁFRICA DO SUL, 2002, p. 5). Desenvolver o conhecimento em relação ao que é o turismo e a como ele pode beneficiar as comunidades locais é visto como um desafio. A capacitação profissional e a formação em todos os níveis são essenciais para o desenvolvimento de uma cadeia produtiva mais inclusiva, capaz de demonstrar sua responsabilidade social e de desenvolver novos produtos que satisfaçam os interesses culturais e de "conhecer as pessoas ${ }^{94 "}$ dos turistas.

O desenvolvimento e a entrega de novos produtos de qualidade para o mercado em mudança é de importância central para permitir que os historicamente desfavorecidos tornem-se parte do turismo Ele também é necessário para a justiça social e para evitar a exploração das culturas locais e dos grupos comunitários. (ÁFRICA DO SUL, 2002, p. 6)

Pode-se afirmar que a África do Sul, dentro do eixo de responsabilidade social de sua política de TR, tem o foco nas populações historicamente desfavorecidas e na sua cultura, buscando princípios que permitam o desenvolvimento de iniciativas que promovam o seu acesso aos benefícios gerados pelo turismo e que apresentem oportunidades em "uma estrutura comercial realista." (ÁFRICA DO SUL, 2002, p. 6).

\footnotetext{
${ }^{94}$ (...) "Meet the People" interests of tourists (ÁFRICA, 2002, p.6)
} 
Nesta perspectiva, são apresentados no documento em questão quatro elementoschave para a criação de iniciativas de turismo de responsabilidade social: a) envolver a comunidade local no planejamento e na tomada de decisão; b) avaliar os impactos sociais como pré-requisito para o desenvolvimento do turismo; c) manter e estimular a diversidade social e cultural; d) ser sensível à cultura da comunidade. Tais elementoschave serão descritos a seguir.

a) "Envolver a comunidade local no planejamento e na tomada de decisão" com atitudes como: buscar compreender o contexto histórico, político e cultural das comunidades locais e de acolhimento, e as relações históricas com o desenvolvimento do turismo e áreas protegidas; incentivar a participação proativa e o envolvimento de todas as partes interessadas incluindo o setor privado, o governo em todos os níveis, do trabalho, das comunidades locais (seus líderes e estruturas) - em todas as fases do ciclo de vida do turismo; programas de educação dentro dos currículos escolares e a conscientização pública no seio das comunidades considerando o respeito aos potenciais aspectos positivos e negativos do turismo; criar programas de ensino pós-emprego e de formação, necessários para educar os funcionários sobre os possíveis prós e contras de turismo, e sobre os custos e benefícios de empresas alternativas comparativas, a fim de auxiliar a tomada de decisão; capacitar as comunidades para o comércio de suas tradições e produtos culturais como ativos e de melhorar suas oportunidades econômicas; criar materiais informativos e centros de informação ao turista, que devem ser desenvolvidos com consulta às comunidades locais.

b) "Avaliar os impactos sociais como pré-requisito para o desenvolvimento do turismo", entre outras formas, ao se identificar e monitorar possíveis impactos sociais advindos do turismo e minimizá-los no curto e no longo prazo, para assegurar-se de que as comunidades participem ativamente no monitoramento; nomear, para grandes empresas, um membro da equipe para assumir a responsabilidade de desenvolver um melhor relacionamento e parcerias locais; implementação de auditorias sociais de projetos de turismo, que podem ser realizadas de uma maneira barata, rápida e participativa; 
consideração de esquemas para encorajar a cooperação local e o orgulho cívico, trabalhar com o governo e a comunidade locais para identificar áreas prioritárias, e torná-los seguras e atraentes para os turistas; desenvolvimento pelas empresas de estratégias de promoção da igualdade de gêneros, etnia, idade e deficiência, e relatar o progresso da implementação;

c) "Manter e estimular a diversidade social e cultural", por meio do desenvolvimento do turismo com dignidade, respeito e nutrindo culturas locais (incluindo a religião), de modo que elas enriqueçam a experiência de turismo e construam um sentimento de orgulho e confiança entre as comunidades locais; uso do turismo como um catalisador para o desenvolvimento humano, com foco na igualdade de gênero, desenvolvimento de carreira e aplicação das normas trabalhistas nacionais; desenvolvimento do turismo sem o comprometimento do respeito pelos direitos sociais, culturais e religiosos, ou dos direitos humanos essenciais das pessoas à alimentação, a um ambiente seguro e limpo, ao trabalho, à saúde e à educação; apoio ao desenvolvimento de empresas de artesanato local sustentáveis, prestando assistência na melhoria de design, marketing, produção e embalagem - considerar especificamente o que pode ser feito para melhorar as habilidades e os salários das mulheres, particularmente nas áreas rurais; incentivo aos turistas a mostrarem respeito por aprender algumas palavras da língua local, (e usálas quando falar com os autóctones), e, ainda, a aprenderem sobre a cultura de acolhimento e tradições;

d) "Ser sensível à cultura da comunidade receptora": para que isso seja alcançado o documento destaca que é preciso incluir cuidados como certificarse de que o turismo não põe em risco o direito ao conhecimento tradicional e as habilidades das comunidades locais; monitorar e abordar de forma proativa, em cooperação com a comunidade, os impactos sociais e culturais negativos associados ao turismo, como o aumento da criminalidade, o uso de drogas e álcool e a prostituição; educar os turistas sobre a cultura local e, se necessário, torná-los conscientes de como devem se comportar para respeitála; combater energicamente e com a cooperação de todos os interessados a exploração de seres humanos, sob qualquer forma, especialmente sexual e quando aplicado a mulheres e crianças. 
A Figura 10, apresentada em seguida, resume de forma esquemática os quatro objetivos da responsabilidade no âmbito social, para a África do Sul, descritos anteriormente.

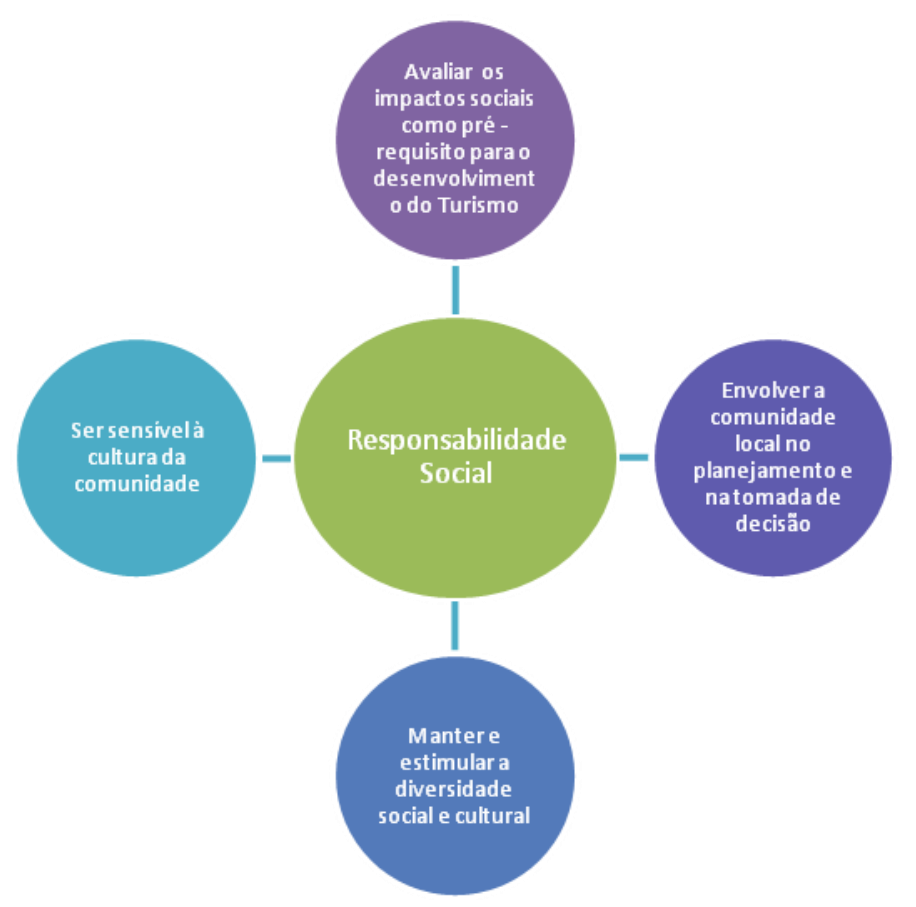

Figura 10: Objetivos da Responsabilidade Social da África do Sul Fonte: Criado a partir do "National Responsible Tourism Development Guidelines for South Africa".

3) Responsabilidade Ambiental: No eixo da responsabilidade ambiental, a política sul-africana considera que o Turismo Responsável implica numa abordagem proativa do setor de turismo para com o meio ambiente, por meio da promoção do turismo sustentável e equilibrado. Destaca-se que esse fato é particularmente importante quando o foco do setor do turismo e das atividades dos turistas concentra-se no ambiente natural, como é o caso da observação da vida selvagem, da caça e do turismo marítimo.

Ainda nessa dimensão, reconhece que existem desafios específicos para se promover o turismo baseado na natureza de forma sustentável, pois o desenvolvimento do turismo responsável precisa ser apoiado em práticas ambientais sustentáveis. Essa política defende que na esfera ambiental apenas decisões de conservação baseadas no princípio da precaução podem ser consideradas responsáveis. 
O documento em análise ressalta que o patrimônio cultural também faz parte do meio ambiente, porém a responsabilidade do setor do turismo em relação ao ambiente cultural foi considerada nas diretrizes de responsabilidade social (anteriormente explanada neste mesmo capítulo). As diretrizes explicitam como todas as empresas turísticas podem contribuir para a sustentabilidade ambiental, por exemplo, ao praticar o cuidado nas decisões de compra, buscando e apoiando produtores responsáveis de insumos necessários para a administração do empreendimento, e fazendo com que seus clientes conheçam a política de compra responsável (ÁFRICA DO SUL, 2002).

São pontuados os seguintes elementos fundamentais para o desenvolvimento do turismo com responsabilidade ambiental: a) avaliar os impactos ambientais como prérequisito para o desenvolvimento do turismo; b) usar os recursos locais de forma sustentável, para se evitar o desperdício e o excesso de consumo; c) manter e estimular a diversidade natural. A seguir detalharemos cada um desses elementos fundamentais.

\section{a) "Avaliar os impactos ambientais como pré-requisito para o desenvolvimento} do turismo" a partir de atitudes como: planejar novos desenvolvimentos apenas em áreas onde o uso de água e de outros recursos naturais para o turismo não entre em conflito com as necessidades da comunidade local, no presente ou em um futuro previsível; integrar a gestão ambiental no ciclo de planejamento do projeto; seguir as orientações de melhores práticas sobre a concepção, planejamento e construção de edifícios e infraestrutura associada para minimizar os impactos ambientais e reduzir os requisitos de energia para iluminação, refrigeração e aquecimento; usar materiais locais (onde sustentável) e estilos arquitetônicos locais em uma escala que não crie um impacto estético negativo; construções de design com ventilação natural e ativamente planejadas para reduzir o uso de recursos durante a construção e as fases operacionais, sempre com a disponibilização de informação aos visitantes do que tem sido feito para tornar a empresa mais amiga do ambiente; planejar novos empreendimentos de uma forma que produza o menor impacto ambiental possível, particularmente em áreas ambientalmente sensíveis, como a zona costeira, florestas indígenas, habitats da vida selvagem e áreas úmidas, com a busca da minimização da transformação do ambiente no seu entorno (ÁFRICA DO SUL, 2002) 
b) "Usar os recursos locais de forma sustentável" para se evitar o desperdício e o excesso de consumo, algumas medidas são destacadas no documento em análise. Aqui citaremos as que consideramos mais relevantes, tais como, a adoção de medidas de redução do consumo de água e energia, além do monitoramento desse uso; o acompanhamento do uso de diesel, parafina e gasolina, com a necessidade de se estabelecer metas para reduzir o consumo e mudar para combustíveis menos poluentes; o aumento da proporção de energia utilizada a partir de recursos renováveis; a instalação e a evidência da tecnologia apropriada para reduzir o consumo de recursos naturais para diminuir a produção de resíduos e as incidências de poluição; trabalhar com os fornecedores para minimizar a quantidade de embalagem adquiridas como suprimentos, e, portanto, reduzir a quantidade de resíduos que precisa ser eliminado; consumir alimentos produzidos localmente; incentivando o uso de transportes "amigos do ambiente".

c) "Manter e estimular a diversidade natural": para a realização disso, algumas atitudes são priorizadas, tais como: adoção de medidas para incentivar o comportamento que respeite o patrimônio natural e com baixo impacto sobre ele; desencorajar a compra de produtos que explorem a vida selvagem de forma insustentável ou que contribuam para a destruição de espécies e habitats (por exemplo, algum artesanato; carne de caça); a busca de meios para que empresas e clientes possam ajudar na conservação do patrimônio natural; investir uma porcentagem dos lucros ou volume de negócios em conservação de espécies ou na restauração e na gestão de habitat; evitar a poluição causada por produtos químicos com o uso de produtos ecologicamente corretos. Informar aos visitantes e funcionários porque a empresa está fazendo isso e como ela beneficia o meio ambiente; trabalhar com as autoridades de conservação para garantir que os visitantes de áreas de patrimônio natural sejam sensibilizados quanto aos impactos de forma a minimizá-los.

Da mesma forma que foi feito nas dimensões da responsabilidade apresentadas anteriormente, na Figura 11, que será exibida a seguir, é possível visualizar o resumo de forma esquemática dos três objetivos da responsabilidade ambiental descritos anteriormente. 


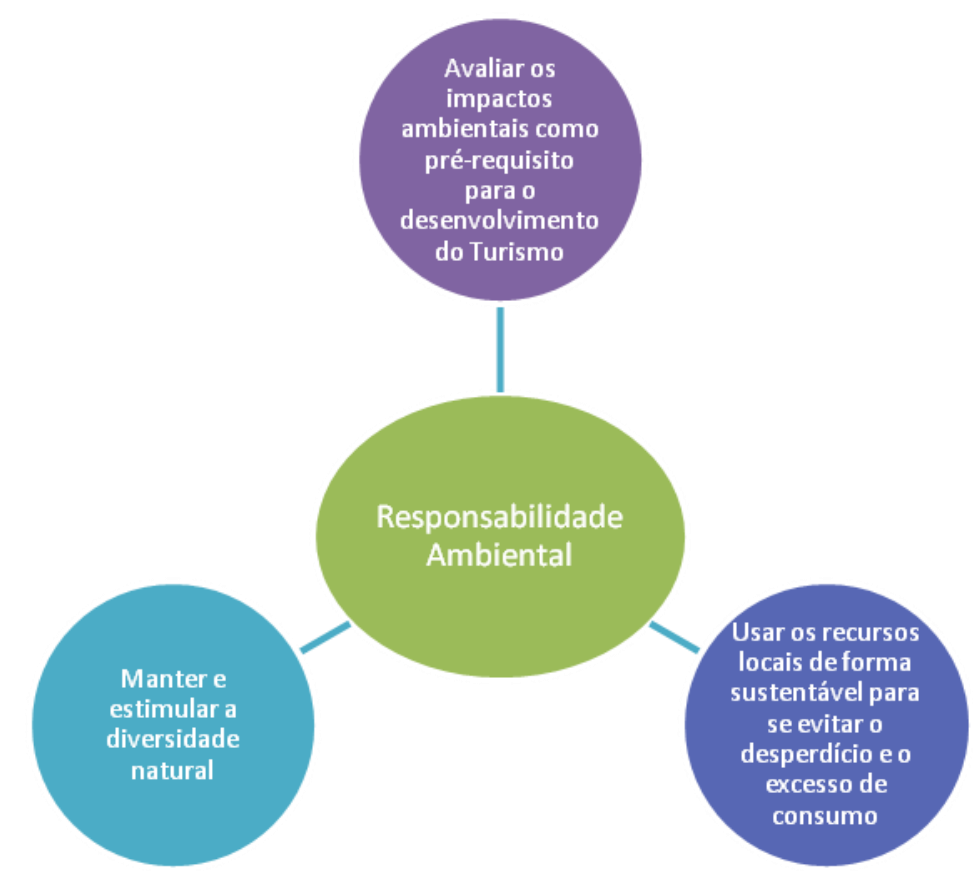

Figura 11 - Objetivos da Responsabilidade Ambiental da África do Sul

Fonte: Criado a partir do "National Responsible Tourism Development Guidelines for South Africa".

Após a análise do referido documento referencial da África do Sul, será feito o estudo da política de Gâmbia, no tópico a seguir.

\subsection{POLÍTICA PÚBLICA DE TURISMO RESPONSÁVEL EM GÂMBIA}

A República da Gâmbia, na África Ocidental, deu início à implantação de uma política de Turismo Responsável no começo dos anos 2000, com base em relatórios produzidos pela STI (Sustainable Tourism Initiative) e conduzida pela Responsible Tourism Partnership. O documento "Responsible Tourism Policy for The Gambia", que aqui será analisado, foi produzido em 2002 e validado em um processo que envolveu múltiplos stakeholders. A iniciativa compartilha das aspirações da Declaração da Cidade do Cabo, de 2002, e tem como grande objetivo "criar lugares melhores para as pessoas viverem e visitarem". Para se desenvolver o Turismo Responsável em Gâmbia, sua política se baseia em 4 eixos de ação: 1) Marketing; 2) Responsabilidade Econômica 3) Responsabilidade Social; e 4) Responsabilidade Ambiental.

${ }^{95}$ (GÂMBIA, 2002) Disponível em http://www.accessgambia.com/information/responsible-travel-policy.html. Acesso em 25/05/2014. 
1) Marketing: para a implantação dos princípios do TR acredita-se que a forma como Gâmbia é divulgada exerce um papel central nesse processo, pois influencia no tipo de investimentos e de turistas que são atraídos para o país. Assim, o marketing é visto como instrumento para se atingir a visão de Turismo Responsável do país. Esse marketing será trabalhado na divulgação da diversidade da oferta turística, aproximando-se de segmentos de mercado que valorizam a herança natural e cultural desse país, para a construção da imagem de Gâmbia como um produto turístico diferenciado capaz de influenciar no perfil do turista que visita o país - o que pode indicar a preocupação de atrair visitantes adequados à prática de turismo almejada por Gâmbia. Entre as estratégias do eixo de marketing, destacam-se:

\begin{abstract}
(...) Construir capacidade local de forma a melhorar a oferta do produto, fornecendo uma diversidade de produtos e serviços turísticos de alta qualidade por meio de SMMEs e de organizações comunitárias em parceria com negócios nacionais e internacionais consolidados; reconhecer que o marketing tem papel fundamental na educação dos turistas sobre a cultura local; e assegurar que os turistas aproveitem ao máximo suas férias pela interação positiva com as comunidades locais. A educação prévia tem um papel chave na consecução do Turismo Responsável em qualquer destino, assegurando a saúde e a segurança dos visitantes e reconhecendo que isso é crítico para o êxito do turismo, e que a saúde e a segurança são importantes para nossas comunidades que também se beneficiam de iniciativas nessa área; assegurando que nosso produto turístico seja acessível a todos, inclusive aos visitantes com deficiência (GÂMBIA, 2002, tradução nossa) $)^{96}$.
\end{abstract}

Dessa forma, verifica-se que o marketing para Gâmbia, no contexto do TR, está diretamente ligado à educação e com a preocupação da acessibilidade. E que ele deve ser usado de forma a valorizar a herança natural e cultural do país, como foi explicado anteriormente, e agora sera mostrado na Figura 12 em seguida.

\footnotetext{
${ }^{96}$ Texto original: (...) Building local capacity to enrich the product offer by providing a diversity of high quality tourism products and services through SMMEs and community organizations generally in partnership with established national and international businesses; recognizing that marketing plays a critical role in educating tourists about the local cultures; and by ensuring that they get the most out of their holiday by enjoying positive interactions with local communities. Pre-arrival education plays a key role in achieving responsible tourism in any destination; ensuring the health, safety and security of visitors, recognizing that this is critical to the success of tourism; and that health, safety and security are also important to our communities who also benefit from initiatives in this area; ensuring that our tourism product is accessible to all - including disabled visitors. (GÂMBIA, 2002)
} 


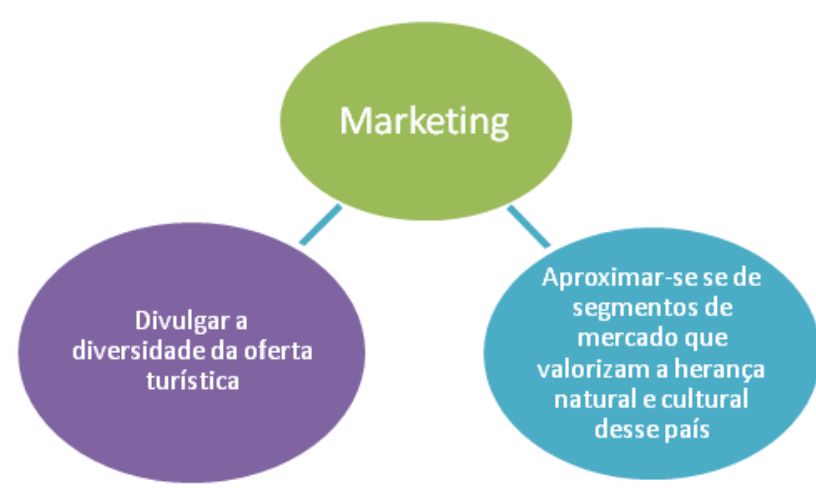

Figura 12 - Objetivos do Marketing de Gâmbia Fonte: Gâmbia, 2002.

2) Responsabilidade Econômica: o país reconhece que as comunidades locais precisam ser envolvidas e se beneficiarem do turismo, e que isto valoriza Gâmbia como um destino turístico, e contribui para o aumento de ganhos financeiros nacionais e locais advindos do turismo. Dentro deste eixo, são três os objetivos almejados: avaliar os impactos econômicos como um pré-requisito do desenvolvimento turístico; maximizar os benefícios econômicos locais - "by increasing linkages and reducing leakages"; implementar a responsabilidade econômica por meio de parcerias e iniciativas conjuntas com envolvimento de todos os stakeholders. Objetivos estes que são apresentados na Figura 13, a seguir. 


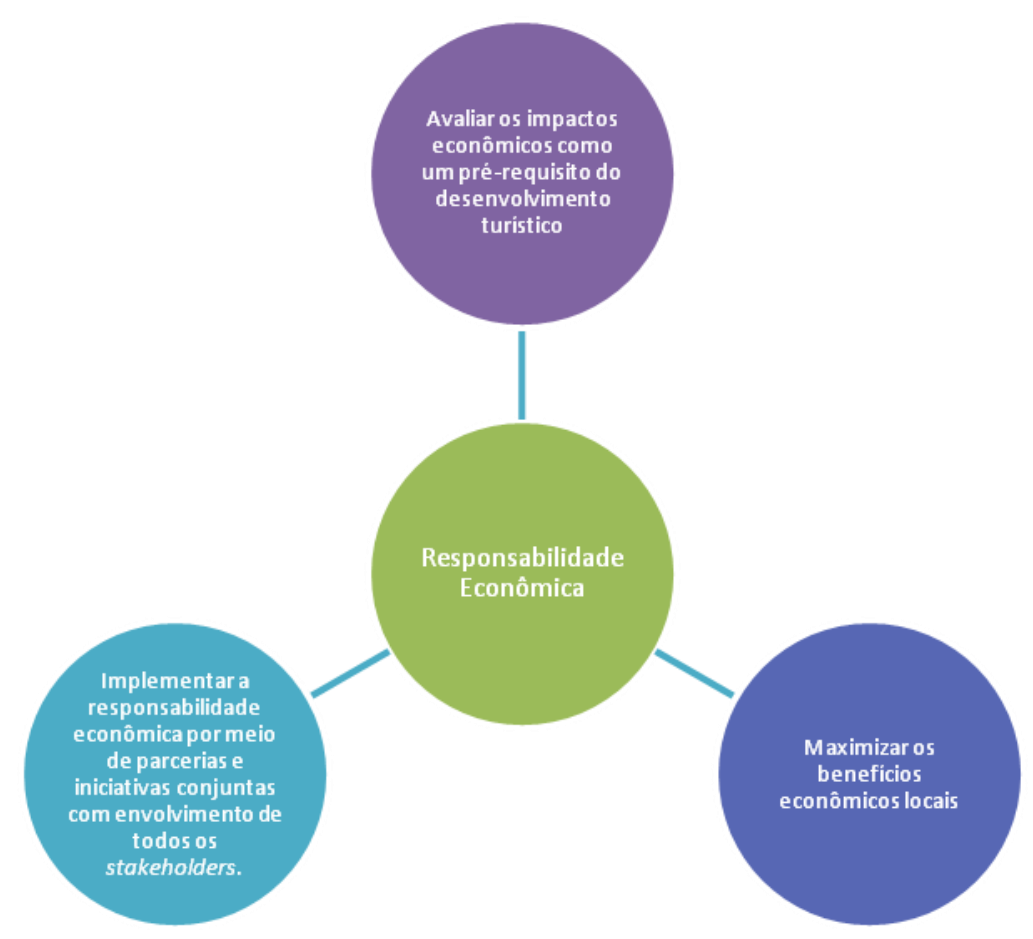

Figura 13 - Objetivos e Premissas da Responsabilidade Econômica de Gâmbia Fonte: GÂMBIA, 2002

3) Responsabilidade Social: ciente de que o turismo promove interações humanas que podem ser positivas, quando, por exemplo, fortalecem a cultura tradicional africana nas relações entre visitantes e anfitriões, ou negativas, gerando problemas sociais, a política de TR de Gâmbia traçou duas incumbências. A primeira seria envolver a comunidade local no planejamento e na tomada de decisão, por meio de uma série de iniciativas específicas, tais como,

Encorajar a participação de todos os stakeholders, dos setores formais e informais, governo e comunidades; envolver a comunidade local criando oportunidades para que se engaje no processo de planejamento para o desenvolvimento do turismo em Gâmbia; (...) despender atenção particular para estratégias práticas que envolvam todos os stakeholders na prevenção da exploração sexual infantil. (GÂMBIA, 2002 ${ }^{97}$ )

\footnotetext{
${ }^{97}$ Disponível em http://www.accessgambia.com/information/responsible-travel-policy.html. Acesso em 25/05/2014.
} 
A segunda obrigação seria manter e promover a diversidade cultural e social. Assim, ressalta-se que:

O desenvolvimento do turismo não deve comprometer o respeito aos direitos sociais, culturais e religiosos. Seja sensível às culturas anfitriãs em Gâmbia e encoraje o reconhecimento de suas riquezas; (...) encoraje visitantes a interagir com os locais como iguais, de maneira estruturada e guiada; desenvolva um um contrato social local, com a participação e contribuição da comunidade, para pautar a interação e o comportamento entre a comunidade local e os turistas (GÂMBIA, 2002, tradução nossa). (GÂMBIA, 2002) ${ }^{98}$

De maneira esquemática, esses objetivos e premissas são apresentados a seguir na Figura 14.

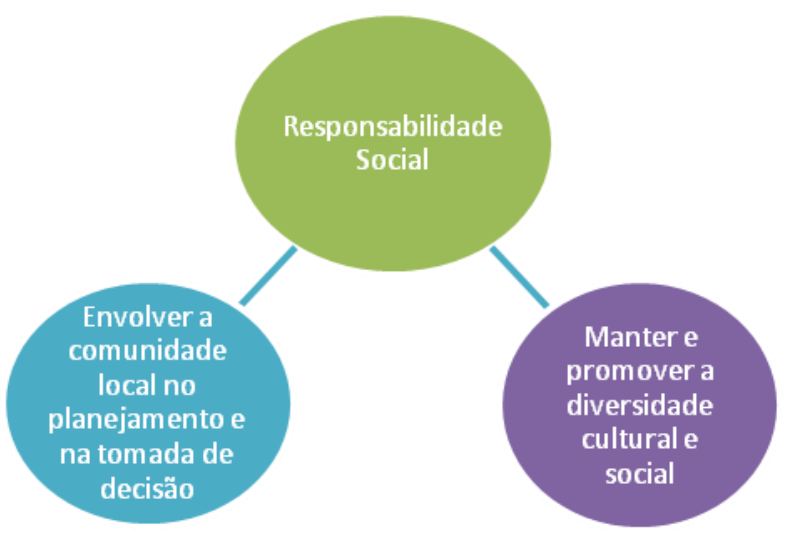

Figura 14 - Objetivos e Premissas da Responsabilidade Social de Gâmbia Fonte: Gâmbia, 2002.

4) Responsabilidade Ambiental: o governo de Gâmbia reconhece o meio ambiente e as riquezas naturais como importantes ativos do turismo no país. Uma vez que o

\footnotetext{
${ }^{98}$ Texto original: "Tourism development should not compromise respect for social, cultural and religious rights; be sensitive to the host cultures of The Gambia and encourage recognition of their richness; (...) encourage opportunities for visitors to interact with locals as equals in a structured and guided manner; develop a local social contract with participation and contributions from the community for interactions and behavior between the local community and tourists."
} 
setor representa um dos maiores consumidores de recursos naturais, entende que os impactos ambientais do turismo devem ser administrados. Dessa forma, a política de TR do país demanda que haja um trabalho que envolva governo e agências ambientais na construção de uma política planejada do turismo, com o objetivo de identificar áreas que deveriam ficar livres de desenvolvimento, para que com isso seja possível garantir o reconhecimento do ambiente natural como fonte vital para a sobrevivência de comunidades locais, além de um dos principais ativos turísticos. Em uma segunda linha de ação para o turismo com responsabilidade ambiental, orienta-se que o turismo deve ser desenvolvido e administrado de forma a garantir o mínimo impacto ambiental. Para isso, o governo de Gâmbia compromete-se, entre outros, a

(...) Conscientize as partes interessadas sobre a importância da adoção de abordagem ambientalmente sustentável e assegure o gerenciamento de resíduos, por meio da redução, reutilização e reciclagem; encoraje os turistas a utilizar a reciclagem e outros métodos de redução de resíduos; forneça educação sobre a importância do ambiente natural, tanto intrinsecamente quanto para o turismo; identifique as melhores práticas por meio de um processo de consultas (...). (GÂMBIA, 2002) (tradução nossa). ${ }^{99}$.

Os objetivos e premissas de Gâmbia para a responsabilidade na dimensão ambiental podem ser resumidos de maneira esquemática na Figura 15 mostrada a seguir.

\footnotetext{
99 Texto original: “(...) Raise awareness among all stakeholders about the importance of adopting an environmentally sustainable approach and ensure the management of waste through reducing, reusing and recycling; encourage tourists to use recycling and other waste reduction methods; provide education about the importance of the natural environment, both intrinsically and for tourism; identify best practice through a consultation process (...)." (GÂMBIA, 2002).
} 


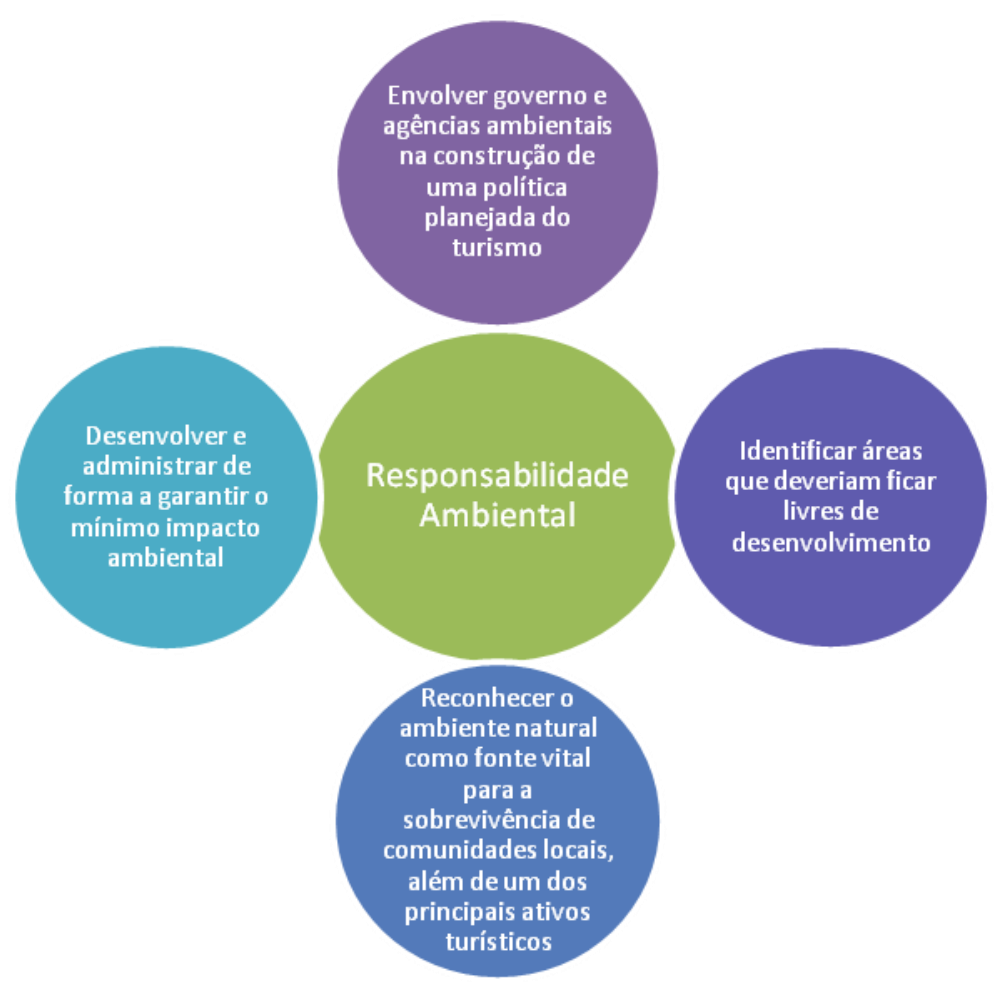

Figura 15 - Objetivos e Premissas da Responsabilidade Ambiental de Gâmbia Fonte: Adaptado de Gâmbia, 2002.

Visto isso, pôde-se observar que Gâmbia dividiu os eixos de atuação de sua política de TR de acordo com os três pilares da sustentabilidade, fim maior do Turismo Responsável. O envolvimento de todos os atores da cadeia produtiva do turismo, um dos preceitos fundamentais do Turismo Responsável, permeia as ações prioritárias da política de TR de Gâmbia, assim como uma preocupação com a forma do turista se relacionar com o destino turístico, de modo a promover, como já indicava Krippendorf (1982), uma "humanização das viagens". 
6 APRESENTAÇÃO E ANÁLISE dAS POLÍTICAS PÚBLICAS DO MINISTÉRIO DO TURISMO

Q ação não se origina do pensamento, mas da prontidão para a responsabilidade.

Dietrich Bonhoeffer 


\subsection{O CONTEXTO ATUAL BRASILEIRO}

Ao se levar em consideração o conceito de Turismo Responsável até aqui discutido, ao buscar suas raízes nas regiões pioneiras no desenvolvimento de suas principais diretrizes e práticas - a partir da publicação de whitepapers, guidelines, estratégias e manuais - e após a identificação de elementos-chave em políticas de TR em curso em países de referência, torna-se possível avaliar se e em que medida a prática também é uma tendência no turismo brasileiro. Ao se tomar como objeto de estudo as iniciativas em curso no Ministério do Turismo do Brasil, coube analisar se o conceito de TR está abarcado, de alguma forma, no Plano Nacional de Turismo do Brasil e nos programas do MTur, e se tais ações indicam uma tendência no Brasil em direção ao Turismo Responsável, tendo em vista a maneira como governos de outros países o adotaram como uma estratégia do turismo e, mais, como meio deste contribuir em temas definidos como prioritários no desenvolvimento dessas nações.

\subsubsection{O Plano Nacional de Turismo $2013-2016$}

Segundo o atual Secretário Nacional de Políticas de Turismo, Vinícius Lummertz Silva, o Plano Nacional de Turismo do Brasil 2013 - 2016 "define as contribuições do setor para o desenvolvimento econômico, social e a erradicação da pobreza" no Brasil. Elaborado como um instrumento de planejamento que comunica as políticas públicas de turismo a serem executadas por determinado período, define como principais diretrizes a geração de oportunidades de emprego e empreendedorismo; participação e diálogo com a sociedade; incentivo à inovação e ao conhecimento; e "regionalização como abordagem territorial e institucional para o planejamento" (BRASIL, 2013a, p. 8). São quatro os objetivos estratégicos: "preparar o turismo brasileiro para os megaeventos; incrementar a geração de divisas e a chegada de turistas estrangeiros; incentivar o brasileiro a viajar pelo Brasil; e melhorar a qualidade e aumentar a competitividade do turismo brasileiro".

Não há menção do Turismo Responsável como uma estratégia do Governo ou do plano de desenvolvimento do turismo nacional, apesar de ações de cunho social e responsável serem uma preocupação, no entanto, pontuais. Dentro das sete grandes 
ações estabelecidas como prioritárias, uma delas inclui o estímulo ao desenvolvimento de um turismo sustentável.

\subsection{Estimular o desenvolvimento sustentável da atividade turística}

6.5.1 Combater a exploração de crianças e adolescentes na cadeia produtiva do turismo (...) O conteúdo da ação refere-se à prevenção e ao enfrentamento da exploração sexual de crianças e de adolescentes nos equipamento turísticos. (...)

6.5.2 Integrar a produção associada na cadeia produtiva do turismo

Promoção da integração da produção local à cadeia produtiva do turismo por meio de (...) criação de metodologias inovadoras e de incentivo à formação de redes que garantam a sustentabilidade das iniciativas locais. (...)

6.5.3 Fomentar o turismo de base comunitária

Fomento e apoio a projetos e ações para o desenvolvimento local e sustentável do turismo (...), particularmente com relação a produtos e serviços turísticos de base comunitária com representatividade da cultura local, valorização do modo de vida ou defesa do meio ambiente. (BRASIL, 2013, p. 98-99)

Essas diretrizes aproximam-se de iniciativas de turismo responsável sem, no entanto, abarcá-lo integralmente ou tê-lo como base de ação. Já o termo "sustentável" está presente, mas de forma genérica. O Plano Nacional de Turismo Brasileiro menciona o conceito de sustentabilidade sem talvez realmente incluir a sua prática nas políticas públicas, que visam o crescimento econômico indiscriminado. Vale dizer que Borges (2013), um pesquisador com estudo no foco do uso do termo sustentabilidade nas políticas do MTur, confirma a hipótese de "uma utilização indiscriminada da sustentabilidade no turismo, especialmente nas políticas públicas federais, permitido pela escassez de reflexões aprofundadas sobre o assunto na área". O estudo de Borges concluiu que a "ideia de desenvolvimento sustentável não está clara". Quanto ao conceito de responsabilidade no turismo, ele não aparece na elaboração do plano nacional estabelecido de 2013-2016.

$O$ viés da sustentabilidade aparece mais do que o de responsabilidade no discurso do Ministério do Turismo, sem, entretanto, adotar um e/ou outro como visão estratégica de planejamento. "(...) Aproveitamos para incluir conceitos que até então ocupavam uma posição periférica na estratégia de turismo no Brasil. A sustentabilidade é um deles. (...)", afirma o então Ministro do Turismo, Gastão Vieira, na mensagem introdutória do PNT 2013 - 2016. O ministro ainda aponta a intenção de desenhar uma política de turismo em áreas protegidas em parceria com o Ministério do Meio Ambiente 
com o intuito de preservar e divulgar a natureza do país e gerar renda para as populações do entorno de parques nacionais (BRASIL, 2013a, p. 6-7).

Vale ressaltar que não são apresentados, no PNT, dados que relacionem o crescimento do turismo como atividade econômica com o índice de desenvolvimento humano (IDH) e social das regiões onde ele se configura como um setor relevante.

A atenção voltada primordialmente aos resultados econômicos e financeiros do turismo é herança de décadas de tensão econômica. "O raciocínio em termos de taxa de crescimento e a realização de índices estatísticos ainda são muito difundidos na política do turismo" (KRIPPENDORF, 1989, p. 186).

Mas se o Turismo Responsável não aparece em momento algum como uma política de desenvolvimento do turismo no Brasil, a preocupação com a inclusão de iniciativas de caráter sustentável e social está presente, o que demonstra, talvez, uma vocação do setor no país para a prática do TR.

Selecionamos, aqui, sete programas atualmente em curso no MTur que, assim como apontado pelas políticas internacionais de TR tomadas como referência nesse estudo, têm relação direta com os princípios e elementos-chave do conceito e das práticas de Turismo Responsável, quais sejam: Programa Turismo Sustentável e Infância (TSI); Turismo de Base Comunitária (Turismo de Base Local); Programa Turismo Acessível; Passaporte Verde; Viaja Mais Melhor Idade; Programa de Regionalização do Turismo e Talentos do Brasil Rural.

Essas iniciativas serão descritas e analisadas a seguir. $\mathrm{O}$ objetivo é analisar essas ações para verificar como a responsabilidade é abarcada pelo MTur, de forma a evidenciar quais as dimensões da responsabilidade são trabalhadas e de que maneira isso é feito.

\subsection{AS INICIATIVAS RESPONSÁVEIS DO MINISTÉRIO DO TURISMO}

Tomado como o conjunto de informações, dados e orientações que norteiam a elaboração de documentos de cunho executivo para ações concretas para o desenvolvimento do turismo, o PNT é a base para a criação de uma série de novas políticas públicas para o setor e a manutenção daquelas elaboradas anteriormente, mas que se apresentam de acordo com as diretrizes estabelecidas. É o caso da maior parte 
das políticas de turismo identificadas por este estudo como tendo na responsabilidade o seu pilar, e, por isso, convergentes ao de Turismo Responsável. Segundo Basso ${ }^{100}$ (2013):

\begin{abstract}
Além dos preceitos e paradigmas que conduzem a vigente política de promoção do desenvolvimento do turismo no Brasil, expressos no Plano Nacional de Turismo 2013 - 2016, estão seus programas, projetos e ações, que demonstram na prática este novo momento, de busca de um turismo mais sustentável e responsável em amplos aspectos. Entre eles, destacam-se o Programa Turismo Sustentável e Infância, que promove o combate à exploração sexual de crianças e adolescentes no setor turístico brasileiro, o Programa Turismo de Base Comunitária, que promove iniciativas diversificadas relacionadas ao tema definição de marcos conceituais, apoio técnico e financeiro a projetos específicos, entre outros. (BASSO, 2013, p. 11-12)
\end{abstract}

Tais iniciativas do MTur podem ser interpretadas à luz do Turismo Responsável, uma vez que têm como princípios-chave alguns daqueles estabelecidos como políticas de TR por meio dos documentos oficiais e práticas já consolidadas nos países de referência, nos quais foram buscados os princípios, as premissas e os objetivos para a análise desenvolvida no presente estudo.

Porém, é valido ressaltar que apesar da presença no MTur de programas, projetos e ações relacionadas à concepção de Turismo Responsável, que serão descritos e analisados a seguir, o termo TR não é usado ou considerado oficialmente em nenhum momento.

\title{
6.2.1 Programa Turismo Sustentável e Infância
}

O Programa Turismo Sustentável e Infância tem como princípios o desenvolvimento sustentável, a responsabilidade social corporativa e os direitos da criança. Assim, objetiva trabalhar a prevenção e o enfrentamento da exploração sexual de crianças e adolescentes em todos os níveis do turismo no Brasil, e desenvolver, por meio da atividade turística, a proteção ao meio ambiente, a redução da pobreza e das desigualdades regionais, com a criação de empregos e a geração de renda.

\footnotetext{
${ }^{100} \mathrm{Em}$ julho de 2013, foi contratada, pelo Ministério do Turismo, consultoria para a produção de um documento técnico conceitual que servisse de base para a construção do "Programa Turismo Responsável". A versão final desse documento serviu de fonte de pesquisa, da qual destaca-se a citação de Basso. Porém, o programa não chegou a ser desenvolvido.
} 
Criado em 2004, o TSI envolve a colaboração de diversas instâncias - Polícias Federal e Civil, Ministério Público, Conselho Tutelar, Secretaria de Direitos Humanos, Casa Civil - e de parceiros do setor turístico - Secretarias Estaduais e Municipais de Turismo, a Câmara Temática do Turismo Sustentável e Infância, o Conselho Nacional de Turismo, empresas de turismo, universidades e membros da sociedade civil. Por meio de ações de educação, estratégias de comunicação, e formação e atuação de multiplicadores ${ }^{101}$ - incluindo a publicação e distribuição do Manual do Multiplicador, contendo vídeo didático e a Cartilha do Projeto de Prevenção à Exploração Sexual de Crianças e Adolescentes no Turismo - o programa formatou uma rede de proteção à criança e ao adolescente na cadeia do turismo.

O projeto direciona a questão do combate à exploração sexual da criança e do adolescente aos atores envolvidos no turismo - desde agências de viagens, rede hoteleira, restaurantes e bares, locadoras de veículos, mídia, ONGs e Sistema "S", a guias de turismo, taxistas, profissionais do setor e até os próprios turistas e a comunidade local -, e cria, assim, nesses mesmos atores, a responsabilidade da prevenção do problema, evidenciando a vulnerabilidade das populações de destinos turísticos em relação ao tema e conduzindo a uma mobilização social ${ }^{102}$.

O programa atua em quatro eixos de ação: 1) Projeto Inclusão Social com Capacitação Profissional - Desde 2008, oferece cursos profissionalizantes ligados ao turismo para jovens em situação de vulnerabilidade social; 2) Projeto de Formação de Multiplicadores; 3) Seminários de Sensibilização - seminários para sensibilizar os empresários do setor, as instituições que trabalham com a temática, membros da sociedade civil e todos os envolvidos com turismo no País. Todos os estados do Brasil já receberam os eventos; e 4) Campanhas - são realizadas campanhas de incentivo às denúncias dos casos de exploração sexual de crianças e adolescentes, anualmente, em eventos de mobilização nacional, com a distribuição de diversos materiais de

\footnotetext{
101 "Multiplicadores são pessoas formadas que disseminam o conhecimento dessa temática em 26 estados e no Distrito Federal. Desenvolvem e implementam, no âmbito do projeto, planos de ação nas 12 cidadessede da Copa de 2014 e campanhas nacionais." Disponível em www.turismo.gov.br. Acesso em março de 2014.

102 De acordo com o Manual do Multiplicador - Projeto de Prevenção à Exploração Sexual de Crianças e Adolescentes no Turismo (2013c, p. 80), "a mobilização ocorre quando um grupo de pessoas, unidas por um motivo, decide e age com um objetivo comum, perseguindo, de forma permanente, mudanças na realidade". "Mobilizar é convocar vontades para atuar na busca de um propósito comum, sob uma interpretação e um sentido também compartilhados" (TORO e WERNECK, 2004, apud. BRASIL, 2013c, p. 80).
} 
comunicação. Em dez anos, o TSI obteve como resultados a capacitação profissional de 1.800 jovens, a formação de 530 agentes locais, a realização de 163 seminários de sensibilização e 110 mil pessoas mobilizadas ${ }^{103}$.

O programa também tem como foco a adoção das empresas privadas do setor de turismo do Código de Conduta (www.thecode.org), documento internacional elaborado em 1999 pela ECPAT (Articulação Internacional contra a Prostituição, Pornografia e Tráfico de Crianças e Adolescentes) junto a essas mesmas companhias, com orientações para a proteção de crianças da exploração sexual no turismo. O código estabelece responsabilidades como treinar funcionários, informar turistas e apresentar relatório anual sobre suas ações e seus resultados referentes à aplicação das diretrizes do Código. Ademais, o programa incentiva a denúncia por meio do Disque 100 ou por email à Secretaria de Direitos Humanos (disquedenuncia@sdh.gov.br).

\title{
6.2.2 Turismo de Base Comunitária
}

Focado na promoção de projetos em diferentes comunidades de destinos turísticos, o programa Turismo de Base Comunitária (TBC) incentiva e dá suporte técnico e/ou financeiro para o desenvolvimento de iniciativas locais, além de propagar o conceito de TBC. A prática tem sido adotada no Brasil, especialmente nas últimas décadas, como uma alternativa sustentável de organização da cadeia do turismo em nível local.

\begin{abstract}
A motivação para o desenvolvimento do Programa derivou de uma demanda social, na qual as iniciativas de TBC no Brasil, individualmente, organizadas em redes, buscaram apoio do MTur para estruturação de suas atividades. Além disso, houve a percepção da potencialidade do TBC no Brasil, devido ao crescente interesse de turistas nacionais e internacionais na busca de experiências (ócio ativas e polivalentes), no convívio com culturas diferentes e ambientes preservados. Outra razão refere-se à capacidade e ao interesse das comunidades locais na oferta de bens e serviços turísticos, além do crescimento das políticas públicas de desenvolvimento local das quais o TBC faz parte, na agenda do governo brasileiro, principalmente de 2003. (BRASIL, 2010, p. 50)
\end{abstract}

O conceito de TBC do MTur coloca a comunidade local como protagonista do processo turístico, como sujeito e não objeto do turismo, valorizando a cultura, as tradições e os negócios locais, fomentando ações que levem ao desenvolvimento

\footnotetext{
${ }^{103}$ Disponível em www.turismo.gov.br. Acesso em março de 2014.
} 
econômico e social das populações autóctones/ receptoras. Assim, faz parte do programa o financiamento de projetos de cunho coletivo e colaborativo, que envolvem os moradores e trabalhadores locais em atividades que fortalecem a identidade local, o senso de pertencimento, a inclusão social, e que buscam alcançar o sentido de comum (coletivo). Dessa forma, o TBC favorece a coesão e o laço social, e, assim, promove, por essa via, uma "maior qualidade de vida, um sentido de inclusão, valorização da cultura local e do sentimento de pertencimento de todos os envolvidos, direta ou indiretamente" e transcende a perspectiva clássica das "comunidades de baixa renda" ou comunidades tradicionais" (IRVING, 2009, apud. BASSO, 2013, p. 27).

O MTur entende Turismo de Base Comunitária (TBC) como um fenômeno econômico e social em que comunidades receptoras assumem o papel de atores principais na oferta dos produtos e serviços turísticos. Assim, atributos da natureza e da cultura são transformados em ativos econômicos para o lazer, entretenimento e divulgação de conhecimento para visitantes e alternativas de inserção socioeconômica da população local nas atividades relacionadas com o turismo (BRASIL, 2010, p. 50).

A maior parte dos projetos sob o guarda-chuva do TBC é desenvolvida em parceria com outras instituições governamentais, como prefeituras e secretarias municipais. O programa, criado oficialmente em 2008 para reunir sob a mesma organização iniciativas de TBC apoiadas isoladamente em anos anteriores, funciona, desde então, com a publicação de Edital de Chamada Pública e o apoio financeiro aos projetos selecionados. A ação do MTur desenvolveu mostras de turismo, em 2009 e 2010, para divulgar os projetos apoiados pelo governo como uma alternativa de se alcançar a diversificação da oferta turística, "com geração de oportunidades de trabalho e renda para a população local e difundir os produto e serviços turísticos de base comunitária (...) como estratégia de apoio à comercialização do destino." (BRASIL, 2010, p. 51).

Entre os projetos apoiados na primeira fase do Programa estão "Apoio às iniciativas de TBC na Reserva de Desenvolvimento Sustentável de Mamirauá - AM", com a qualificação e a inserção da comercialização dos produtos e serviços prestados pelas comunidades locais - que participam das tomadas de decisão e da gestão do ecoturismo na região - no mercado pan-amazônico; "Promoção do Turismo Social e Cultural de Base Comunitária no Sertão do Kariri - CE”, com o fomento da oferta de 
pousadas domiciliares e foco principal na promoção e comercialização da Fundação Casa Grande - Memorial do Homem Kariri (Nova Olinda/ CE) e da região do Kariri, para atração de demanda externa; entre outros que envolvem Turismo Rural de Base Comunitária, ações de desenvolvimento econômico e social para o fortalecimento de arranjos produtivos locais, incubação de cooperativas populares da cadeia produtiva do turismo e a inserção de jovens de baixa renda em atividades ligadas ao turismo em diversos estados (BRASIL, 2010).

Por meio do apoio, principalmente financeiro, às iniciativas das comunidades locais na cadeia do turismo, gera-se o empoderamento daquelas, que passam a atuar como protagonistas na oferta de produtos e serviços de turismo. Além disso, promove-se a inclusão social e maior qualidade de vida.

\subsubsection{Programa Turismo Acessível}

Inserido no âmbito do Turismo Social, o Ministério do Turismo trabalha o Turismo Acessível, de forma transversal a todas as políticas do órgão. "A visão do MTur é que o Turismo seja uma via de inclusão, entendendo que o turismo social é uma forma de turismo acessível a todos os cidadãos em seus tempos livres, sem discriminação de acessos de qualquer natureza" (BRASIL, 2014b) ${ }^{104}$

O MTur apoia projetos os quais visam à acessibilidade urbana, à adaptação de atividades turísticas e à sensibilização e disseminação de orientações acerca da acessibilidade nos mais diversos setores ligados direta e indiretamente à atividade turística, com o intuito de garantir a acessibilidade a todos, independentemente das diferenças (BRASIL, 2014b) ${ }^{105}$.

Nesse cenário, o MTur já realizou diversas iniciativas, tais como o levantamento de informações sobre a acessibilidade da infraestrutura turística dos principais destinos brasileiros; a capacitação profissional de pessoas com deficiência visando sua inclusão no mercado de trabalho; a elaboração do estudo "Perfil do Turista - Pessoas com

\footnotetext{
${ }^{104}$ Disponível em www.turismo.gov.br

${ }^{105}$ Disponível em www.turismo.gov.br
} 
Deficiência" ${ }^{106}$; a produção da Cartilha Turismo Acessível ${ }^{107}$ - volumes I a IV; entre outras iniciativas $^{108}$.

No que se refere, atualmente, às ações direcionadas às pessoas com deficiência, existe hoje em curso o Programa Turismo Acessível - política de acessibilidade para o período de 2012 - 2014. Esse Programa foi lançado em novembro de 2012 pelo MTur em parceria com a Embratur e a Secretaria de Direitos Humanos da Presidência da República. Possui o foco no atendimento à necessidade de inclusão das pessoas com deficiência ou com mobilidade reduzida nas atividades e serviços turísticos, com a finalidade de permitir o alcance e a utilização de serviços, edificações e equipamentos turísticos com segurança e autonomia.

Este Programa recomenda várias medidas para a promoção da inclusão social e o acesso de pessoas com deficiência ou mobilidade reduzida aos benefícios da atividade turística, permitindo o alcance e a utilização dos equipamentos turísticos com segurança e autonomia.

Possui os seguintes objetivos específicos: Realização de estudos e pesquisas para apoiar o setor público, privado e terceiro setor na estruturação de destinos e produtos turísticos acessíveis; Orientação aos profissionais e gestores da cadeia produtiva do turismo, por meio da disseminação de conhecimentos, quanto à importância da acessibilidade como fator de inclusão social e competitividade para o turismo; Incentivo à ampliação do número de unidades habitacionais (UHs) acessíveis nas 12 cidades-sede da Copa do Mundo e seus entornos; Implantação de um sistema de certificação de informações acerca da acessibilidade de empreendimentos e atrativos turísticos de destinos brasileiros; Apoio à implantação e adequação de infraestrutura

\footnotetext{
106 "Esse estudo foi uma parceria com a Secretaria de Direitos Humanos da Presidência da República e com a UNESCO. A pesquisa realizada pela empresa CP2 Pesquisas, de 13 a 20 de maio de 2013, nos cinco principais centros emissores de turistas brasileiros, utilizou-se do método de discussão com grupos focais e entrevistas em profundidade e teve por objetivo identificar as características, comportamentos de consumo e necessidades dos turistas com deficiência (reais e potenciais), conhecendo suas percepções em relação à infraestrutura e ao atendimento nas cidades, as barreiras e empecilhos para a realização de viagens, suas expectativas e seus relatos de experiências positivas e negativas" (BRASIL, 2014b). Disponível em www.turismo.gov.br

107 Essas cartilhas apresentam a execução do projeto Sensibilização para o Turismo Acessível, no município de Socorro, em São Paulo. Com o objetivo de apresentar os resultados alcançados por meio desta experiência, foram produzidos quatro volumes, intitulados Turismo Acessível (BRASIL, 2014b). Disponível em www.turismo.gov.br

${ }^{108}$ Para mais informações acessar:

http://www.turismo.gov.br/turismo/o_ministerio/publicacoes/cadernos_publicacoes/17turismo_acessivel.ht $\mathrm{ml}$
} 
turística e de apoio ao turismo acessível nas 12 cidades-sede da Copa do Mundo; Incentivo ao acesso de pessoas com deficiência no mercado de trabalho do turismo; Promoção e apoio ao posicionamento de destinos e produtos turísticos acessíveis, em âmbitos nacional e internacional; Apoio à comercialização de destinos e produtos acessíveis. ${ }^{109}$

Os resultados esperados desse Programa são: estudos e pesquisas disponibilizados ao setor público, privado e terceiro setor para subsidiar a estruturação de destinos e produtos turísticos acessíveis; 8.000 pessoas qualificadas e sensibilizadas para o tema acessibilidade como fator de inclusão social e competitividade para 0 turismo; Aumento para 5\% de unidades habitacionais (UHs) acessíveis nas 12 cidadessede da Copa do Mundo e seus entornos; 100 obras de infraestrutura turística acessíveis, realizadas nas 12 cidades-sede da Copa do Mundo; Informações acerca da acessibilidade de empreendimentos e atrativos turísticos de destinos brasileiros, disponibilizadas por meio de sistema online; Pessoas com deficiência inseridas no mercado de trabalho do turismo; e Destinos e produtos turísticos acessíveis promovidos nos mercados nacional e internacional. ${ }^{110}$

No ano de 2013, o MTur realizou uma pesquisa para ampliar o conhecimento sobre o segmento, e assim, oferecer subsídios para ações relacionadas ao tema. E pretende implantar em 2014 um sistema de certificação de informações sobre acessibilidade de empreendimentos e atrativos turísticos de destinos (BRASIL, 2014a) ${ }^{111}$

Vale destacar, que o Programa visa beneficiar um amplo campo ao envolver gestores públicos e privados, profissionais de linha de frente do turismo, empreendimentos turísticos, destinos turísticos, pessoas com deficiência e/ou com mobilidade reduzida (turistas e não turistas).

Ao propiciar a inclusão de pessoas com deficiência na atividade turística, o programa vai ao encontro das ações e iniciativas do Governo Federal que buscam defender e garantir condições de vida com dignidade, a plena participação e inclusão na sociedade, e a igualdade de oportunidades a todas as pessoas com deficiência.

Nessa perspectiva, o Programa Turismo Acessível busca reunir as iniciativas e ações relacionadas à acessibilidade existentes no âmbito do Ministério do Turismo e

\footnotetext{
${ }^{109}$ Encarte do Programa Turismo Acessível, disponível em www.turismo.gov.br

${ }^{110} /$ dem.

${ }^{111}$ Publicação do Ministério do Turismo. Balanço de Gestão. Janeiro de 2014.
} 
Embratur para a construção de uma política de inclusão social que possa ser implementada de forma sinérgica entre todas as áreas da pasta, Embratur e instituições.

\subsubsection{Passaporte Verde}

O Passaporte Verde é uma campanha internacional lançada em 2008 pela International Task Force on Sustainable Tourism Development - ITF-STD - em parceria com o Programa das Nações Unidas para o Meio Ambiente - PNUMA -, o Ministério Francês do Meio Ambiente e Desenvolvimento Sustentável, os Ministérios do Meio Ambiente e do Turismo do Brasil, que mostra de que maneira o comportamento do turista "pode contribuir para a conservação do meio ambiente e para a melhoria da qualidade de vida das pessoas" (MINISTÉRIO DO MEIO AMBIENTE et al, 2009, p.139). No Brasil, ela é coordenada pelos Ministérios do Meio Ambiente e do Turismo do Brasil e conta com parceiros nacionais e internacionais da iniciativa pública e privada ${ }^{112}$ e incluiu os grandes eventos esportivos internacionais realizados ou a realizar no país, especialmente no processo de planejamento e execução da Copa do Mundo FIFA 2014, focados principalmente na construção de arenas sustentáveis, Selo de Sustentabilidade Baixo Carbono, Gestão Sustentável de Resíduos Sólidos e Campanha Brasil Orgânico e Sustentável.

É uma campanha com base na internet - que engloba um site oficial e redes sociais ${ }^{113}$-, que tem o objetivo de criar nos turistas a consciência do potencial de contribuírem para o desenvolvimento sustentável fazendo escolhas responsáveis de férias. Uma versão impressa da campanha já foi lançada em português, inglês e espanhol. Outros países já fazem parte da Campanha, como Costa Rica, Equador e África do Sul. Em 2009, Parati (RJ) foi a primeira cidade a implementar a campanha em nível local, com material de divulgação nas rádios, na televisão e também com a versão em português do guia.

\footnotetext{
${ }^{112}$ Ministério do Desenvolvimento Social e Combate à Fome (MDS), Ministério do Esporte (ME), Itaú Unibanco, BRAZTOA (Associação Brasileira das Operadoras de Turismo), UNICEF (Fundo das Nações Unidas para a Infância), UNESCO (Organização das Nações Unidas para a Educação, a Ciência e a Cultura), Organização Internacional do Trabalho (OIT), Programa Conjunto das Nações Unidas sobre HIV/Aids (UNAIDS), (Escritório das Nações Unidas sobre Drogas e Crime), Associação de Hotéis Roteiros de Charme e Fundação Amazonas Sustentável (FAS).

${ }^{113}$ www.passaporteverde.org.br; www.passaporteverde.gov.br
} 
A Campanha Passaporte Verde compreende uma série de iniciativas, mas ela está focada, principalmente, nas atitudes do turista em relação aos destinos que visitam.

O passaporte é um aliado do viajante que tem a preocupação com o meio ambiente cada vez mais presente no seu dia a dia. Conservar a biodiversidade e usar racionalmente os recursos naturais fazem parte dessa nova atitude de cuidado com os destinos turísticos. Este tipo de turismo respeita o meio ambiente, favorece a economia local e o desenvolvimento das sociedades que você visita. (MINISTÉRIO DO MEIO AMBIENTE et al, 2009, p.140)

A principal ferramenta da Campanha é o "Passaporte Verde", uma cartilha com o objetivo de sensibilizar e educar o visitante quanto sua postura na hora de viajar e traz uma série de dicas e recomendações sobre a importância de se informar na hora de escolher o seu destino, em relação a meios de transporte como também a maneira de se portar em relação à comunidade local, entre outros.

Além disso, recomenda atitudes responsáveis sobre bagagem, o que levar na viagem e estadia, incentivando "práticas verdes" e a adoção da prática dos 5 R's da conduta ambiental ${ }^{114}$.

Se você é um turista responsável e bem informado, na hora de escolher o destino: certifique-se de que o destino oferece meios de transporte, acomodações, tratamento de lixo e esgoto e políticas mais sustentáveis, assim como respeito à cultura e à comunidade; (...) Esteja preparado para pagar um pouco mais pela viagem, se isso significar salários justos para quem vive na região, ou contribuir com recursos que possam ser revertidos para a proteção de áreas sensíveis e paisagens naturais. (...)

Quando estiver fazendo as malas, pense cuidadosamente no que realmente precisa levar. A quantidade de itens na sua bagagem aumenta o impacto da sua viagem, pelas emissões de gás carbônico e pelo lixo que você produz. Cuidado com pilhas, baterias e lâmpadas. Esses pequenos objetos contêm materiais tóxicos que contaminam a água e o solo quando descartados de forma inadequada. (MINISTÉRIO DO MEIO AMBIENTE et al, 2009, p. 49-50; 60-61).

O PNUMA, em parceria com os Ministérios do Meio Ambiente, do Esporte e do Turismo do Brasil, lançou em 2014 uma edição especial da campanha Passaporte Verde durante a Copa do Mundo no Brasil. Essa nova edição atualiza a linguagem e os meios de comunicação da campanha, disponibilizando uma plataforma de comunicação ao

\footnotetext{
114 "Repensar hábitos e atitudes; recusar produtos que agridam a saúde e o meio ambiente; reduzir a geração e o descarte; reutilizar para aumentar a vida útil dos produtos; reciclar e transformá-los num novo produto." (MINISTÉRIO DO MEIO AMBIENTE et al, 2009, p. 79).
} 
turista e ao setor do turismo, que inclui website, aplicativo para smartphone e uma plataforma de comunicação ao turista e ao setor do turismo, que inclui website, aplicativo para smartphone e uma estratégia de campanha nas redes sociais. O Passaporte Verde 2014 reúne 60 roteiros sustentáveis nas doze cidades-sede da Copa, e oferece ao turista engajado a oportunidade de comentar e compartilhar suas experiências durante 0 Mundial.

Aqui, a visão do "novo turista", o turista consciente, informado e educado, ou seja, a atitude e o comportamento do turista em relação à viagem e aos destinos visitados, preocupações presentes em iniciativas responsáveis, aparecem como elemento-chave para o desenvolvimento do turismo.

\subsubsection{Viaja Mais - Melhor Idade}

O Programa Viaja Mais - Melhor Idade foi instituído pelo MTur em 2007, com dois objetivos gerais, sendo um deles com um pilar na responsabilidade por abordar à inclusão social por meio do turismo. Ao proporcionar o acesso do público idoso às viagens de lazer o órgão demonstra preocupação com a função social que o turismo pode exercer. O segundo objetivo é importante para o desenvolvimento do turismo no Brasil, pois se baseia na finalidade de estimular o turismo interno, ao fazer com que aposentados, pensionistas e maiores de 60 anos aproveitem seu tempo livre para viajar pelo país. Este fato é relevante para a diminuição da sazonalidade do turismo, já que esse público possui disponibilidade para viajar fora de temporada (BRASIL, 2013b) ${ }^{115}$.

Vale destacar, que o programa possui objetivos específicos que vão ao encontro da preocupação com a melhoria da qualidade dos serviços turísticos, tais como: Fortalecer o mercado interno, dinamizando a cadeia de distribuição do turismo e proporcionando maior estabilidade ao setor de serviços; Estimular a atividade turística, principalmente em períodos de baixa ocupação, como mecanismo de aumento da competitividade dos destinos nacionais e redução dos efeitos da sazonalidade; Proporcionar ao público-alvo maior conhecimento do país, de sua natureza, de sua cultura e de sua gente, incentivando a cultura da viagem; Fomentar as viagens internas por meio de mecanismos que viabilizem a oferta de produtos de qualidade e acessíveis

\footnotetext{
${ }^{115}$ Brasil. Ministério do Turismo. Cartilha Viaja Mais Melhor Idade $-2^{\underline{a}}$ edição. Brasília: Ministério do Turismo, 2013b. 22 p.
} 
a idosos, aposentados e pensionistas; Estimular o desenvolvimento de um mercado turístico segmentado para o público idoso, que permita uma relação real entre a qualidade e o preço dos serviços turísticos nacionais; Estimular o aprimoramento e a diversificação dos produtos turísticos já comercializados para o público idoso; Fortalecer o desenvolvimento econômico das pequenas e médias empresas, que compõem a maior parte da atividade turística nacional.

O programa foi o primeiro braço operacional de uma iniciativa maior do Ministério do Turismo, o Viaja Mais. Sua primeira fase, encerrada em 2010, foi um sucesso: com a disponibilidade de tempo e recursos que caracterizam o público da melhor idade, promoveu-se o aumento das taxas de ocupação dos prestadores de serviços turísticos e, consequentemente, a redução dos efeitos da sazonalidade. Entre os anos de 2007 e 2010, 599 mil pacotes turísticos foram vendidos no âmbito do Viaja Mais Melhor Idade, gerando mais de $\mathrm{R} \$ 531$ milhões.

Atualmente está em curso a $2^{\underline{a}}$ edição do Viaja Mais Melhor Idade, com uma proposta mais abrangente, mais flexível, de mais fácil acesso e com mais descontos e vantagens para o turista. Nessa nova ótica, idosos, aposentados e/ou pensionistas poderão ter à sua disposição, além de pacotes turísticos, ofertas de hospedagens, cruzeiros, locação de veículos, parques, atrações turísticas, entre outros.

Destina-se, ainda, a fazer com que esse público entenda as facilidades que terá para viajar a partir de agora, de modo a estimulá-lo a usufruir os benefícios do turismo em lazer, cultura e novos relacionamentos.

O programa funciona por meio de um site. O portal Viaja Mais Melhor Idade foi elaborado pensando na comodidade e conforto do seu público-alvo. Por meio do portal www.viajamais.gov.br, o turista poderá verificar a lista de vantagens e descontos oferecidos pelas empresas credenciadas. É fácil e rápido visualizar as ofertas. O sistema de busca possibilita encontrar ofertas por estado, por município, por período, por empresa e por tipo. Também é possível organizar a pesquisa de ofertas por preço e por mais acessadas. A página traz ainda todas as informações sobre o programa, materiais didáticos, dicas de como bem atender e formatar produtos para a melhor idade e atendimento online para tirar dúvidas do usuário.

Também possibilita integração com redes sociais, cada vez mais usadas pelo público-alvo. Depois de viajar, o turista poderá deixar o seu comentário e avaliar os prestadores dos quais compraram produtos ou serviços. 
O portal é, assim, um catálogo. Ao acessá-lo, o turista consegue visualizar as ofertas disponíveis e, com base nas condições especificadas pelo vendedor, escolher aquela em que tem maior interesse. Escolhida a oferta desejada, o cliente tem à sua disposição os contatos da empresa para que possa realizar a compra e viajar pelo Brasil com descontos e/ou vantagens.

\subsubsection{Programa Talentos do Brasil Rural}

O Programa Talentos do Brasil Rural é resultado de um Acordo de Cooperação Técnica assinado, em 2009, pelo Ministério do Turismo - MTur e Ministério do Desenvolvimento Agrário - MDA, que procura fortalecer a relação entre a agricultura familiar e a atividade turística.

A predominante presença da agricultura familiar no meio rural brasileiro e o expressivo número de empreendimentos e atividades turísticas a ela vinculadas proporcionou o surgimento de uma forma complementar de renda para os agricultores, conhecida como turismo rural na agricultura familiar.

O turista ao conhecer a propriedade do agricultor familiar tem a possibilidade de não só consumir os serviços de hospedagem, de alimentação e os atrativos turísticos, como também, adquirir produtos artesanais e agropecuários produzidos por agricultores familiares, característicos da região visitada, o que gera nova possibilidade de renda e agrega valor ao que é oferecido ao turista.

Entretanto, o consumo de tais produtos não deve ficar restrito às visitas de turistas às propriedades familiares. Ele pode ser feito em centros urbanos, para onde se desloca um número maior de turistas. Afinal, quando alguém visita São Paulo e se hospeda em um hotel de negócios, consome um suco no café da manhã, utiliza um sabonete e leva para casa o artesanato vendido na loja vizinha. Todos estes produtos podem ser fornecidos por agricultores familiares.

Assim, a criação desse Programa teve o objetivo geral de "Inserir produtos e serviços da agricultura familiar no mercado turístico, agregando valor à oferta turística brasileira", e como objetivos específicos: "Conhecer e alinhar oferta e a demanda do mercado turístico de produtos e serviços da agricultura Familiar"; "Qualificar e agregar valor aos serviços e produtos da agricultura familiar existentes, para distribuição e comercialização no mercado turístico"; "Iniciar a preparação dos agricultores familiares 
para a prestação de serviços aos turistas e oferta de produtos diferenciados ao mercado turístico - em hotéis, bares, restaurantes, lojas de artesanato - na Copa do Mundo de 2014, agregando valor socioambiental e sustentabilidade ao produto turístico"; e "Apoiar a promoção e comercialização de produtos, serviços e destinos da agricultura familiar".

O projeto está estruturado em dois eixos: Produtos da Agricultura Familiar e Roteiros e Serviços Turísticos. E possui como ações: Seleção de empreendimentos e roteiros participantes; Diagnóstico dos participantes do roteiro (visita in loco de técnicos do Projeto e realização de workshop com os participantes do roteiro para apresentar os resultados - pontos fracos e fortes); Elaboração de planos de ação; Qualificação dos empreendimentos e roteiros (consultorias para formação de redes, roteirização turística, gestão de negócios, aperfeiçoamento de produtos e geração de experiências e inovações); Estudos de mercado (elaboração de Planos de Posicionamento no Mercado); Promoção e apoio à comercialização dos produtos e serviços da agricultura familiar para o mercado turístico (participação em feiras e eventos; produção de material promocional, realização de rodada de negócios, entre outros).

Os resultados esperados são: produtos e serviços da agricultura familiar, inseridos no mercado turístico das 12 cidades- sedes da Copa; Ampliação de canais de comercialização para os agricultores familiares; Reposicionamento de 24 roteiros turísticos, aumentando sua competitividade; Diversificação, ampliação e melhoria da oferta de produtos associados ao turismo em 12 cidades-sedes.

O Talentos do Brasil Rural tem como órgão financiador o Ministério do Desenvolvimento Agrário, que investiu cerca de 3 milhões de reais no projeto e também trabalhou em sua elaboração. O Sebrae é o órgão executor, tendo, recentemente, também aportado recursos. Ministério do Meio Ambiente e Agência de Cooperação Alemã - GIZ foram apoiadores do projeto em seu início.

Ao Ministério do Turismo coube a elaboração conjunta do projeto, a gestão compartilhada, a coordenação e a produção técnica acerca do eixo "Serviços", além da realização da etapa de diagnóstico nos roteiros. As ações do eixo produtos são capitaneadas por SEBRAE e MDA. 


\subsubsection{Programa De Regionalização Do Turismo}

Propõe a estruturação, o ordenamento e a diversificação da oferta turística no país e se constitui no referencial da base territorial do Plano Nacional de Turismo. É, dessa forma, um modelo de gestão de política pública descentralizada, coordenada e integrada, com base nos princípios de flexibilidade, articulação, mobilização, cooperação inter setorial e interinstitucional e na sinergia de decisões como estratégia orientadora dos demais macro programas, programas e ações do PNT (BRASIL, 2013d).

Integra um conjunto de projetos e ações relacionado ao planejamento das regiões turísticas nas 27 unidades federativas. Contempla desde atividades de articulação, sensibilização e mobilização até a elaboração e a implantação dos planos estratégicos das regiões turísticas. Tem efetiva atuação por meio da institucionalização de instâncias de governança regional, na formação de redes, na monitoria e na avaliação do processo de regionalização em âmbitos municipal, estadual e nacional.

Em 2013, o país ganhou um novo modelo de estruturação e ordenamento territorial para o desenvolvimento do turismo com a conclusão do trabalho de reformulação do Programa.

\subsection{ANÁLISE DAS INICIATIVAS RESPONSÁVEIS DO MINISTÉRIO DO TURISMO}

Para a análise das iniciativas responsáveis adotadas pelo Ministério do Turismo, serão utilizados os critérios definidos a partir da investigação das políticas públicas de Turismo Responsável (TR) da África do Sul e de Gâmbia - realizada no Capítulo 5 conforme o planejamento dessa dissertação. Além desses critérios, a análise fundamentar-se-á na Declaração da Cidade do Cabo (2002). A aplicação dos princípios norteadores de tal declaração na análise justifica-se pelo fato de que, após a construção da fundamentação teórica e do exame das políticas referenciadas, constatou-se ser ela documento-referência quando se fala em TR, tendo a referida declaração inclusive subsidiado o desenvolvimento das políticas de TR da África do Sul e de Gâmbia.

O exame detalhado desses documentos evidenciou princípios, objetivos e premissas de TR que poderão ser utilizados como elementos fundamentais para a análise das iniciativas do MTur, pois serão eles os critérios analíticos da gestão pública brasileira, ferramentas de avaliação do quão responsáveis são as iniciativas do MTur. 
Tem-se, assim, o intento de revelar quais ações do MTur podem ser consideradas responsáveis e qual ou quais dimensões elas abarcariam, de forma a: i) atingir o objetivo geral dessa dissertação, qual seja, "analisar as iniciativas em curso no Ministério do Turismo sob a ótica do Turismo Responsável" - bem como a ii) responder à questão de pesquisa: "As atuais políticas públicas do MTur contemplam de alguma forma o Turismo Responsável nos seus diversos campos - ambiental, social, cultural e econômico?".

É importante lembrar que não há nessa análise a finalidade de avaliação do desempenho das iniciativas, portanto, não apresentaremos nem faremos ponderações sobre seus resultados.

Inicialmente, observou-se que as políticas internacionais utilizadas como base documentos-referência - para a investigação das políticas nacionais fazem separações em tais documentos. A África do Sul separa-o em três temas - a responsabilidade econômica, a social e a ambiental. Já Gâmbia divide-o em quatro linhas de ação marketing, responsabilidades econômica, social e ambiental. Vale ressaltar que, no documento sul-africano, o marketing está dentro do tema responsabilidade econômica e que, em ambos os documentos, a dimensão cultural é tratada dentro da social. Para a análise desse capítulo, optamos por tratar essas divisões como dimensões da responsabilidade. Diante disso, foi, então, oportuno adotarmos apenas três divisões: responsabilidades econômica, social e ambiental.

Nos quadros de 03 a 09 serão apresentadas essas análises de forma esquemática. Cada quadro expõe uma iniciativa do MTur e é dividido em três colunas. A primeira coluna é subdividida nas dimensões da responsabilidade; a segunda trata do resultado do mapeamento dos princípios, objetivos e premissas de TR, explícitos nos documentos-referência, que sejam relacionados à iniciativa brasileira em análise; e a terceira contém as percepções ou visualizações desses princípios, objetivos e premissas de TR que estejam implícitos na iniciativa do MTur sob exame. A terceira coluna, portanto, trará os objetivos, as metas e, até mesmo, os trechos contidos nos manuais e cartilhas das iniciativas do MTur que possam ser relacionados aos critérios retirados das políticas internacionais.

Os parágrafos exibidos seguidamente a cada quadro dizem respeito à análise geral da iniciativa correspondente, com base no que foi apresentado em sua respectiva descrição feita no início desse mesmo Capítulo, somado às informações mostradas em 


\title{
seu quadro e, ainda, nos princípios norteadores do TR cunhados na Declaração da Cidade do Cabo (2002) que guardam correspondência com a iniciativa do MTur.
}

\author{
Quadro 04
}

Análise das iniciativas de Turismo Responsável do MTur - 01

\begin{tabular}{|c|c|c|}
\hline \multicolumn{3}{|c|}{ ANALISE DAS INICIATIVAS DE TURISMO RESPONSAVEL DO MINISTERIO DO TURISMO } \\
\hline & 1- PROGRAMA TURISMO SUSTENT & ÄVEL E INFÄNCIA (TSI) \\
\hline $\begin{array}{c}\text { DIMENSÕES DA } \\
\text { RESPONSABILIDADE }\end{array}$ & $\begin{array}{l}\text { PRINCIPIOS, OBJETIVOS E PREMISSAS DE } \\
\text { TURISMO RESPONSÁVEL EXPLÍCITOS } \\
\text { NOS DOCUMENTOS-REFERÊNCIA } \\
\text { RELACIONADOS Ȧ INICIATIVA EM } \\
\text { ANÁLISE }\end{array}$ & $\begin{array}{l}\text { EVIDÊNCIAS DOS PRINCÍPIOS, OBJETIVOS E PREMISSAS } \\
\text { DE TURISMO RESPONSÁVEL DOS DOCUMENTOS- } \\
\text { REFERÊNCIA NA INICIATIVA EM ANÁLISE }\end{array}$ \\
\hline Econômica & & - \\
\hline \multirow{7}{*}{ Social } & $\begin{array}{l}\text { Combater a exclusão social, sendo possível } \\
\text { contribuir, inclusive, para a diminuição dos } \\
\text { índices de criminalidade, muitas vezes } \\
\text { relacionados ao ou gerados pelo turismo } \\
\text { (PRINCíPIO - AFRICA DO SUL, 2002). }\end{array}$ & $\begin{array}{l}\text { “Dar continuidade às campanhas publicitárias de mobilização e } \\
\text { aos seminários de sensibilização para a formação de } \\
\text { multiplicadores, bem como implementar o projeto de } \\
\text { inclusão social de jovens nos segmentos do turismo em } \\
\text { todo o País”. } \\
\text { “- Responsabilidade Social e Inclusão: Promover e realizar } \\
\text { projetos de responsabilidade social, com foco na inclusão } \\
\text { socioeconômica das comunidades turísticas.” (Eixo do } \\
\text { programa Turismo Sustentável e Infância - Relato de } \\
\text { experiência - Formação de Multiplicadores). }\end{array}$ \\
\hline & $\begin{array}{l}\text { Monitorar e abordar de forma proativa, em } \\
\text { cooperação da comunidade, os impactos } \\
\text { sociais e culturais negativos associados ao } \\
\text { turismo, como o aumento da criminalidade, o } \\
\text { uso de drogas e álcool e a prostituição } \\
\text { (PREMISSA - ÁFRICA DO SUL, 2002). }\end{array}$ & $\begin{array}{l}\text { "Disseminar ações de responsabilidades para todos os } \\
\text { agentes da cadeia produtiva do turismo. (...) foram criadas } \\
\text { oficinas de Formação de Multiplicadores, que consistem em } \\
\text { mobilizar, articular e sensibilizar o pessoal inserido no setor } \\
\text { turístico para aderir a essa rede de proteção às crianças e } \\
\text { adolescentes contra a cadeia de exploradores". }\end{array}$ \\
\hline & \multirow{3}{*}{$\begin{array}{l}\text { Combater energicamente, e com a } \\
\text { cooperação de todos os interessados, a } \\
\text { exploração de seres humanos, sob qualquer } \\
\text { forma, especialmente sexual e quando } \\
\text { aplicado a mulheres e crianças (PREMISSA - } \\
\text { ÁFRICA DO SUL, 2002). }\end{array}$} & $\begin{array}{l}\text { "O TSI tem como objetivos a prevenção e o enfrentamento } \\
\text { da exploração sexual de crianças e adolescentes nos } \\
\text { equipamentos do turismo e como princípios o desenvolvimento } \\
\text { sustentável, a responsabilidade social corporativa e os } \\
\text { direitos das crianças". }\end{array}$ \\
\hline & & $\begin{array}{c}\text { "Um dos princípios que orienta essa ação é disseminar o } \\
\text { sentimento da corresponsabilidade. Todos, com seus } \\
\text { papéis diferentes, deverão ser protagonistas dessa } \\
\text { empreitada". }\end{array}$ \\
\hline & & $\begin{array}{l}\text { "O TSI sensibiliza os profissionais que integram a cadeia } \\
\text { produtiva do turismo no sentido de contribuir para a garantia } \\
\text { dos direitos das crianças e adolescentes no enfrentamento } \\
\text { da exploração sexual deles nos equipamentos turísticos". }\end{array}$ \\
\hline & \multirow{2}{*}{$\begin{array}{c}\text { Despender atenção particular para estratégias } \\
\text { práticas que envolvam todos os } \\
\text { stakeholders na prevenção da exploração } \\
\text { sexual infantil (GÂMBIA, 2002). }\end{array}$} & $\begin{array}{c}\text { "Fomentar a adoção de projetos de responsabilidade social } \\
\text { corporativa e estimular a mobilização social para a garantia } \\
\text { dos direitos das crianças e adolescentes". }\end{array}$ \\
\hline & & $\begin{array}{l}\text { “- Qualificação: Formar profissionais capazes de identificar, } \\
\text { prevenir e denunciar a exploração sexual, por meio de } \\
\text { cursos, oficinas, palestras e seminários, entre outros métodos } \\
\text { educativos- Mobilização e Articulação: Sensibilizar e } \\
\text { mobilizar empresários e trabalhadores do setor turístico do } \\
\text { setor público e de ONGs na promoção de ações } \\
\text { cooperadas para a prevenção à exploração.” (Eixos do } \\
\text { programa Turismo Sustentável e Infância -Relato de } \\
\text { experiência - Formação de Multiplicadores). }\end{array}$ \\
\hline Ambiental & - & - \\
\hline
\end{tabular}


Após a descrição do Programa Turismo Sustentável e Infância realizada no item 6.2.1 desse Capítulo, conjuntamente com o Quadro 04 exposto anteriormente, é possível afirmar que o TSI contempla apenas a responsabilidade em sua dimensão social. Esse Programa instrumentaliza os atores do setor turístico a responderem a um problema do campo social, e, dessa forma, sinaliza uma preocupação com o desenvolvimento do turismo de uma maneira responsável.

Nota-se, pelas evidências expostas nesse quadro, que a iniciativa busca "combater a exclusão social" na medida em que procura promover a inclusão social por meio do turismo - tanto de jovens, por meio da inclusão nos segmentos do turismo, quanto das comunidades turísticas, por meio de projetos de responsabilidade social. E, ainda, preocupa-se não só com o combate a esse tipo de exploração, como também com a "promoção de ações cooperadas para a prevenção à exploração".

Outro ponto importante na dimensão social, que pode ser observado no quadro, é a preocupação com a abordargem de forma proativa, com participação da comunidade e de todos os interessados, para combater os problemas sociais causados ou agravados pelo turismo. Como ficou claro, o Programa afirma que dissemina ações de responsabilidade, as quais envolvem todos os agentes da cadeia turística, com o intuito de mobilizar, articular e sensibilizar para aderir às ações de uma rede de proteção às crianças e adolescentes. Nesse sentido, observa-se que tanto África do Sul, quanto Gâmbia destacam a importância do envolvimento de todos os stakeholders no combate à exploração sexual de crianças e adolescentes no MTur, o que indica que o Brasil abarca, nessa ação, princípios importantes do TR na dimensão social.

Esse sentimento de corresponsabilidade pode ser relacionado com o conceito de responsabilidade apresentado por Alexander, Goodwin e Robinson, anteriormente explicado nesse trabalho, quando se referem à responsabilidade como a "capacidade de responder ou reagir"116. Seria todos tomarem para si a responsabilidade e, então, agirem e reagirem para a prevenção e o combate dos problemas que a comunidade sofre pelos impactos negativos do turismo.

Em virtude dos fatos mencionados pode-se dizer que esse Programa incorpora diretamente em todas as suas ações o seguinte princípio norteador da Declaração da Cidade do Cabo (2002): "Combater a exploração sexual de seres humanos, em particular a exploração de crianças". Além disso, ao verificarmos que o TSI procura

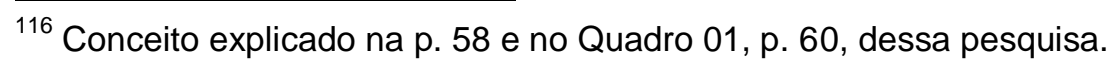


"implementar o projeto de inclusão social de jovens nos segmentos do turismo em todo o País", ele abarcaria de alguma forma o princípio da mesma declaração: "Esforçar-se para tornar o turismo uma experiência social inclusiva e para garantir que haja acesso para todos, em especial as comunidades e indivíduos vulneráveis e desfavorecidos", uma vez que usaria o turismo para incluir socialmente jovens que estariam à margem da sociedade, qualificando-os para serem inseridos no mercado de trabalho.

Apesar das evidências expostas, ainda existem lacunas a serem preenchidas para que o programa TSI se adeque de forma completa ao que o TR propõe, visto que as dimensões econômica e ambiental não são atingidas por essa iniciativa. 0 Programa, além de qualificar jovens em situação de vulnerabilidade social, poderia promover oportunidades econômicas reais e criar situações de fortalecimento econômico dessas comunidades vulneráveis, ao determinar como base de suas ações, por exemplo, o fomento ao empreendedorismo local, com o incentivo à elevação e à atualização de padrões de serviços de pequenas, médias e microempresas e empreendedores individuais emergentes, ou ainda estimular o desenvolvimento de produtos turísticos de base comunitária e a inovação dos roteiros turísticos com o uso dos recursos locais de forma sustentável. Assim, todas as dimensões poderiam ser incorporadas.

\section{Quadro 05}

Análise das iniciativas de Turismo Responsável do MTur - 02

\begin{tabular}{|c|c|c|}
\hline \multicolumn{3}{|c|}{ ANÁLISE DAS INICIATIVAS DE TURISMO RESPONSAVEL DO MINISTERIO DO TURISMO } \\
\hline $\begin{array}{l}\text { DIMENSÕES DA } \\
\text { RESPONSABILIDADE }\end{array}$ & $\begin{array}{l}\text { PRINCİPIOS, OBJETIVOS E PREMISSAS } \\
\text { DE TURISMO RESPONSÁVEL } \\
\text { EXPLÍCITOS NOS DOCUMENTOS- } \\
\text { REFERÊNCIA RELACIONADOS À } \\
\text { INICIATIVA EM ANÁLISE }\end{array}$ & $\begin{array}{l}\text { EVIDÊNCIAS DOS PRINCÍPIOS, OBJETIVOS E } \\
\text { PREMISSAS DE TURISMO RESPONSÁVEL DOS } \\
\text { DOCUMENTOS-REFERÊNCIA NA INICIATIVA EM } \\
\text { ANÁLISE }\end{array}$ \\
\hline \multirow{3}{*}{ Econômica } & $\begin{array}{l}\text { Fomento do empreendedorismo local e de } \\
\text { oportunidades para os historicamente } \\
\text { desfavorecidos, para a redução da pobreza, } \\
\text { a geração de empregos e o } \\
\text { desenvolvimento do mercado de trabalho } \\
\text { e da economia local (PRINCÍPIO - ÁFRICA } \\
\text { DO SUL, 2002). }\end{array}$ & $\begin{array}{l}\text { "Agregar valor aos destinos turísticos, diversificando a } \\
\text { oferta turística de destinos consolidados e } \\
\text { incrementando o fluxo de turistas demandantes deste } \\
\text { segmento; contribuir para a geração de trabalho e } \\
\text { renda local" (BRASIL, 2010, p. 50) }\end{array}$ \\
\hline & $\begin{array}{l}\text { Beneficiar-se da criação de serviços e } \\
\text { produtos complementares, e com isso, } \\
\text { tornar as populações tradicionalmente } \\
\text { menos favorecidas, como comunidades } \\
\text { rurais e em situação de pobreza, } \\
\text { fornecedoras desses produtos e serviços } \\
\text { turísticos (PRINCÍPIO - ÁFRICA DO SUL, } \\
\text { 2002). } \\
\text { Maximizar os benefícios econômicos } \\
\text { locais e garantir que as comunidades } \\
\text { estejam envolvidas e se beneficiem com } \\
\text { o turismo (OBJETIVOS - ÁFRICA DO SUL, } \\
\text { 2002; GÂMBIA, 2002). }\end{array}$ & $\begin{array}{c}\text { "Tem como objetivo identificar produtos associados } \\
\text { ao turismo, como forma de ampliação e diversificação } \\
\text { da oferta turística. Propõe meios de alavancar as } \\
\text { oportunidades e superar os desafios para incorporar } \\
\text { esses produtos e adequá-los ao mercado e ao } \\
\text { processo de comercialização do turismo, } \\
\text { contribuindo para a inclusão social por meio da } \\
\text { geração de trabalho e renda." }\end{array}$ \\
\hline & $\begin{array}{l}\text { Suporte às comunidades locais, aos } \\
\text { artesãos e novos empreendedores no } \\
\text { desenvolvimento de seus produtos e }\end{array}$ & $\begin{array}{l}\text { "O Programa de Desenvolvimento e Promoção da } \\
\text { Produção Associada ao Turismo fomenta e promove a } \\
\text { produção local que detém atributos naturais e/ou }\end{array}$ \\
\hline
\end{tabular}




\begin{tabular}{|c|c|c|}
\hline \multicolumn{3}{|c|}{ ANÁLISE DAS INICIATIVAS DE TURISMO RESPONSAVEL DO MINISTERIO DO TURISMO } \\
\hline 2- & \multicolumn{2}{|c|}{ PRODUÇAO ASSOCIADA AO TURISMO E TURISMO DE BASE COMUNITARIA (TBC) } \\
\hline $\begin{array}{l}\text { DIMENSÕES DA } \\
\text { RESPONSABILIDADE }\end{array}$ & $\begin{array}{l}\text { PRINCIPIOS, OBJETIVOS E PREMISSAS } \\
\text { DE TURISMO RESPONSÁVEL } \\
\text { EXPLÍCITOS NOS DOCUMENTOS- } \\
\text { REFERÊNCIA RELACIONADOS À } \\
\text { INICIATIVA EM ANÁLISE }\end{array}$ & $\begin{array}{l}\text { EVIDÊNCIAS DOS PRINCÍPIOS, OBJETIVOS E } \\
\text { PREMISSAS DE TURISMO RESPONSÁVEL DOS } \\
\text { DOCUMENTOS-REFERÊNCIA NA INICIATIVA EM } \\
\text { ANÁLISE }\end{array}$ \\
\hline & $\begin{array}{c}\text { fomento do desenvolvimento de produtos } \\
\text { turísticos de base comunitária } \\
\text { (PREMISSAS - ÁFRICA DO SUL, 2002). } \\
\text { Capacitação das comunidades para o } \\
\text { comércio de suas tradições e produtos } \\
\text { culturais como ativos e de melhorar suas } \\
\text { oportunidades econômicas (PREMISSA - } \\
\text { ÁFRICA DO SUL, 2002). }\end{array}$ & $\begin{array}{l}\text { culturais dos setores artesanal, industrial e } \\
\text { agropecuário. Tem como foco de atuação segmentos } \\
\text { econômicos como o artesanato, a gastronomia, a } \\
\text { agricultura (...)" (BRASIL, 2010, p. 38) }\end{array}$ \\
\hline & $\begin{array}{l}\text { Criar uma cadeia produtiva mais inclusiva, } \\
\text { capaz de demonstrar sua responsabilidade } \\
\text { social e de desenvolver e fornecer novos } \\
\text { produtos de qualidade que satisfaçam os } \\
\text { interesses culturais e de "conhecer pessoas" } \\
\text { dos turistas (PRINCíPIOS - ÁFRICA DO } \\
\text { SUL, 2002). }\end{array}$ & $\begin{array}{l}\text { “Este programa foi criado para coordenar ações } \\
\text { estratégicas que considerassem a inclusão da } \\
\text { produção local no desenvolvimento do turismo, } \\
\text { cooperando para um posicionamento de mercado do } \\
\text { destino turístico que evidencie suas características } \\
\text { específicas e/ou singulares como a gastronomia, a } \\
\text { produção do artesanato ou as suas festas populares. Há } \\
\text { a evidência de que inserir a produção local na } \\
\text { estruturação dos produtos turísticos é um fator de } \\
\text { sustentabilidade com grande impacto para o } \\
\text { desenvolvimento local" (BRASIL, 2010, p. 38). }\end{array}$ \\
\hline \multirow{3}{*}{ Social } & $\begin{array}{c}\text { Envolver a comunidade local no } \\
\text { planejamento e na tomada de decisões } \\
\text { (OBJETIVO - ÁFRICA DO SUL, 2002; } \\
\text { GÂMBIA). }\end{array}$ & $\begin{array}{c}\text { "O MTur entende Turismo de Base Comunitária (TBC) } \\
\text { como um fenômeno econômico e social em que } \\
\text { comunidades receptoras assumem o papel de atores } \\
\text { principais na oferta de produtos e serviços turísticos". } \\
\text { (BRASIL, 2010, p. 50) }\end{array}$ \\
\hline & $\begin{array}{l}\text { Desenvolver o turismo com dignidade, } \\
\text { respeito e nutrindo culturas locais } \\
\text { (incluindo a religião), de modo que elas } \\
\text { enriqueçam a experiência de turismo e } \\
\text { construam um sentimento de orgulho e } \\
\text { confiança entre as comunidades locais } \\
\text { (PREMISSA - ÁFRICA DO SUL, 2002). }\end{array}$ & $\begin{array}{l}\text { "(...) organizar e fortalecer os atores/as comunidades } \\
\text { para a gestão e a oferta de bens e serviços } \\
\text { turísticos; promover a interação entre a comunidade } \\
\text { e turista, de forma sustentável, com ganhos para a } \\
\text { população local, materiais e simbólicos, e oferecer uma } \\
\text { experiência turística diferenciada para o visitante a } \\
\text { partir da sua participação na vida comunitária local". } \\
\text { (BRASIL, 2010, p. 50). }\end{array}$ \\
\hline & $\begin{array}{c}\text { Manter e estimular a diversidade social e } \\
\text { cultural (OBJETIVO, ÁFRICA DO SUL, 2002; } \\
\text { GÂMBIA, 2002). }\end{array}$ & $\begin{array}{l}\text { "A maior parte das iniciativas de turismo de base } \\
\text { comunitária é resultado da mobilização e organização } \\
\text { da sociedade civil, baseadas no modo de vida e na } \\
\text { cultura do local." (BRASIL, 2010, p. 50). }\end{array}$ \\
\hline \multirow[b]{2}{*}{ Ambiental } & $\begin{array}{l}\text { Estímulo ao consumo de alimentos } \\
\text { produzidos localmente (PREMISSA, ÁFRICA } \\
\text { DO SUL, 2002). }\end{array}$ & $\begin{array}{l}\text { O Programa de Desenvolvimento e Promoção da } \\
\text { Produção Associada ao Turismo fomenta e promove a } \\
\text { produção local que detém atributos naturais e/ou } \\
\text { culturais dos setores artesanal, industrial e } \\
\text { agropecuário. Tem como foco de atuação segmentos } \\
\text { econômicos como o artesanato, a gastronomia, a } \\
\text { agricultura (...)" (BRASIL, 2010, p. 38) }\end{array}$ \\
\hline & $\begin{array}{l}\text { Usar os recursos locais de forma sustentável } \\
\text { (OBJETIVO, ÁFRICA DO SUL, 2002). }\end{array}$ & $\begin{array}{l}\text { "(...) as ações foram direcionadas para resgatar e } \\
\text { ressaltar os valores da cultura, adequar o design e } \\
\text { aplicar a tecnologia para manejo sustentável das } \\
\text { matérias primas" (BRASIL, 2010, p. 39). }\end{array}$ \\
\hline
\end{tabular}

Ao relacionar a exposição das características dessa iniciativa feita no item 6.2.2 com a análise realizada no quadro anterior, verificamos que ela se enquadra nas três dimensões da responsabilidade - na econômica, na social e na ambiental.

A Coordenação do MTur responsável por esse programa, apoia projetos que buscam a inclusão da produção local no desenvolvimento do turismo, o que contribui para a valorização da cultura local. Ainda, a inserção de produtos locais dentro da cadeia do destino turístico é um aliado à sustentabilidade, com desdobramentos positivos no desenvolvimento local. 
Ao analisar o Quadro 05, é possível perceber que essa ação mostra-se bem completa e abarca diversos princípios, objetivos e premissas tanto da África do Sul, como de Gâmbia. Com a evidência, na terceira coluna do quadro, de particularidades em comum daqueles com o Programa - por meio da explicitação de características tais como: "contribuir para a geração de trabalho e renda local", "identificar produtos associados ao turismo (...) alavancar oportunidades (...) incorporar esses produtos $\mathrm{e}$ adequá-los ao mercado (...) para a inclusão social por meio da geração de trabalho e renda", e "inclusão da produção local no desenvolvimento do turismo" - busca-se mostrar que ele atinge a dimensão econômica quando envolve, por exemplo, princípios econômicos da África do Sul que afirmam a importância para o desenvolvimento do TR da "geração de empregos e o desenvolvimento do mercado de trabalho e da economia local", e a "criação de serviços e produtos complementares".

Ainda pela análise do quadro em questão, é perceptível, também, a preocupação com a dimensão social, uma vez que se busca, por exemplo, organizar e fortalecer os atores e as comunidades para "a gestão e a oferta de bens e serviços turísticos", característica esta que se relaciona com o objetivo social da África do Sul para o TR, que afirma a importância de "envolver a comunidade local no planejamento e na tomada de decisões".

Por último, nota-se também a preocupação do programa com a dimensão ambiental, ao incentivar ações que adequem o design e a aplicação de tecnologia para o "manejo sustentável das matérias primas".

Levando-se em consideração esses aspectos entendemos que essa iniciativa abarca alguns princípios orientadores presentes na Declaração da Cidade do Cabo (2002), tais como: na dimensão econômica - "Maximizar os benefícios econômicos locais, aumentando as ligações e reduzindo vazamentos, assegurando que as comunidades estejam envolvidas e se beneficiando do turismo"; "Desenvolver produtos de qualidade que refletem, complementam e melhoram o destino"; "Desenvolver o marketing turístico de modo a refletir a integridade natural, cultural e social do destino, e que incentive formas adequadas de turismo"; na dimensão social - "Ser sensível à cultura da comunidade local, mantendo e encorajando a diversidade social e cultural"; e na dimensão ambiental: "Usar os recursos de forma sustentável, e reduzir o desperdício e o excesso de consumo". 
Por outro lado, embora tenhamos destacado o alcance das três dimensões da responsabilidade, percebe-se a existência de princípios da Declaração da Cidade do Cabo (2002) que poderiam ser incorporados para que essa iniciativa atuasse ainda com mais responsabilidade. Estes seriam, principalmente, os princípios que envolvem as questões de avaliação dos impactos econômicos, sociais e ambientais. Ressalta-se que a avaliação econômica deve acontecer antes do turismo ser desenvolvido, reconhecendo que a atividade turística pode não ser sempre a forma mais adequada de desenvolvimento econômico local; e que a avaliação dos impactos sociais deve ocorrer em todo o ciclo de vida da operação - incluindo as fases de planejamento e concepção de projetos - a fim de minimizar os impactos negativos e maximizar os positivos; e, por fim, que a ponderação ambiental necessita incidir-se ao longo do ciclo de vida dos estabelecimentos turísticos e operações - incluindo a fase de planejamento e design - de modo a garantir que os impactos negativos sejam reduzidos ao mínimo e os positivos maximizados.

\section{Quadro 06}

Análise das iniciativas de Turismo Responsável do MTur - 03

\begin{tabular}{|c|c|c|}
\hline \multicolumn{3}{|c|}{ ANÁLISE DAS INICIATIVAS DE TURISMO RESPONSAVEL DO MINISTERIO DO TURISMO } \\
\hline \multicolumn{3}{|c|}{3 - PROGRAMA TURISMO ACESSIVEL } \\
\hline $\begin{array}{c}\text { DIMENSÕES DA } \\
\text { RESPONSABILIDADE }\end{array}$ & $\begin{array}{l}\text { PRINCÍPIOS, OBJETIVOS E PREMISSAS } \\
\text { DE TURISMO RESPONSÁVEL } \\
\text { EXPLÍCITOS NOS DOCUMENTOS- } \\
\text { REFERÊNCIA RELACIONADOS À } \\
\text { INICIATIVA EM ANÁLISE }\end{array}$ & $\begin{array}{l}\text { EVIDÊNCIAS DOS PRINCÍPIOS, OBJETIVOS E } \\
\text { PREMISSAS DE TURISMO RESPONSÁVEL DOS } \\
\text { DOCUMENTOS-REFERÊNCIA NA INICIATIVA EM } \\
\text { ANÁLISE }\end{array}$ \\
\hline Econômica & $\begin{array}{l}\text { Fomentar o desenvolvimento de } \\
\text { oportunidades de acesso para todos os } \\
\text { visitantes e potenciais visitantes, } \\
\text { independente de suas condições físicas ou } \\
\text { mentais. O aumento da acessibilidade gera } \\
\text { incentivos financeiros e proporciona imagem } \\
\text { positiva (PREMISSA - ÁFRICA DO SUL, 2002). }\end{array}$ & $\begin{array}{c}\text { "Trata-se de um importante segmento da população que } \\
\text { tem dificuldades em realizar viagens de lazer (...) } \\
\text { "potenciais consumidores" (BRASIL, 2014b, p.15). } \\
\text { "Promover e apoiar o posicionamento e } \\
\text { comercialização de destinos e produtos turísticos } \\
\text { acessíveis, nos âmbitos nacional e internacional” } \\
\text { (OBJETIVO ESPECÍFICO - BRASIL, 2014b, p.25) }\end{array}$ \\
\hline \multirow[b]{2}{*}{ Social } & $\begin{array}{c}\text { Garantir que todos os cidadãos tenham } \\
\text { igual acesso aos serviços de turismo, } \\
\text { tanto como consumidores quanto como } \\
\text { fornecedores (PREMISSA - ÁFRICA DO } \\
\text { SUL, 2002). }\end{array}$ & $\begin{array}{c}\text { "Foram definidos seis eixos de atuação para direcionar a } \\
\text { implementação de ações, de forma sinérgica, entre } \\
\text { Estado, a sociedade civil e o mercado turístico, em prol } \\
\text { de uma sociedade mais justa, igualitária e humana } \\
\text { para todos" (BRASIL, 2014b, p.19). } \\
\text { "Incentivar o acesso de pessoas com deficiência no } \\
\text { mercado de trabalho do turismo" (OBJETIVO ESPECÍFICO } \\
\text { - BRASIL, 2014b, p.25). }\end{array}$ \\
\hline & $\begin{array}{c}\text { Desenvolver estratégias de promoção da } \\
\text { igualdade de gêneros, etnias, idade e } \\
\text { deficiência (PREMISSA - ÁFRICA DO SUL, } \\
\text { 2002). }\end{array}$ & $\begin{array}{c}\text { "Promover a inclusão social e o acesso de pessoas } \\
\text { com deficiência ou mobilidade reduzida à atividade } \\
\text { turística, de modo a permitir o alcance e a utilização de } \\
\text { serviços, edificações e empreendimentos turísticos com } \\
\text { segurança e autonomia" (OBJETIVO GERAL - BRASIL, } \\
\text { 2014b, p.25). } \\
\text { "Realizar estudos e pesquisas para apoiar os setores } \\
\text { públicos, privado e terceiro setor na estruturação de } \\
\text { destinos e produtos turísticos acessíveis"; } \\
\text { "Disponibilizar informações sobre acessibilidade de } \\
\text { empreendimentos e atrativos turísticos do Brasil”; } \\
\text { "Melhorar a qualidade dos serviços e } \\
\text { empreendimentos turísticos, em relação à } \\
\text { acessibilidade" (OBJETIVOS ESPECÍFICOS - } \\
\text { BRASIL, 2014b, p.25) }\end{array}$ \\
\hline Ambiental & & \\
\hline
\end{tabular}


Posteriormente à apresentação do Programa Turismo Acessível realizada no item 6.2.3 desse Capítulo, somada às informações expostas no Quadro 06, é possível afirmar que esse programa contempla a responsabilidade em suas dimensões econômica e social.

Verifica-se que ele envolve diversas ações, que vão desde a produção de materiais educativos, passando por qualificação de pessoal para lidar com esse público-alvo e até mesmo ações interativas com os próprios deficientes físicos, como o lançamento do portal "Turismo Acessível".

Analisando o quadro em pauta, é interessante observar que ao se promover a responsabilidade social com a inclusão desse público na atividade turística e com a promoção de oportunidades para melhorar a qualidade dos serviços turísticos, está também se realizando a responsabilidade econômica, uma vez que essas pessoas são potenciais consumidores, e, como mostrado em uma premissa da África do Sul (2002), "o aumento da acessibilidade gera incentivos financeiros e proporciona imagem positiva".

O grande foco do Programa Turismo Acessível, como fica evidenciado no Quadro 06, é a responsabilidade social, visto que ele busca uma "sociedade mais justa, igualitária e humana para todos", envolvendo, por exemplo, as premissas da África do Sul de garantia de igual acesso aos serviços turísticos por todos os cidadãos e de desenvolvimento de estratégias de promoção da igualdade, ao promover "a inclusão social e o acesso de pessoas com deficiência ou mobilidade reduzida à atividade turística".

Em vista dos aspectos evidenciados, entende-se que esse Programa possui foco direto em atender o seguinte princípio orientador para a responsabilidade social da Declaração da Cidade do Cabo (2002): "Esforçar-se para tornar o turismo uma experiência social inclusiva e para garantir que há acesso para todos, em especial as comunidades e indivíduos vulneráveis e desfavorecidos".

Diante do exposto, percebe-se que essa iniciativa é essencial na busca da inclusão social, e que dentro das dimensões que é focada mostra-se completa e abrangente, constituindo-se um respeitável contribuidor para a responsabilidade social no turismo. 
Quadro 07

Análise das iniciativas de Turismo Responsável do MTur - 04

ANALISE DAS INICIATIVAS DE TURISMO RESPONSAVEL DO MINISTERIO DO TURISMO 4 - PASSAPORTE VERDE

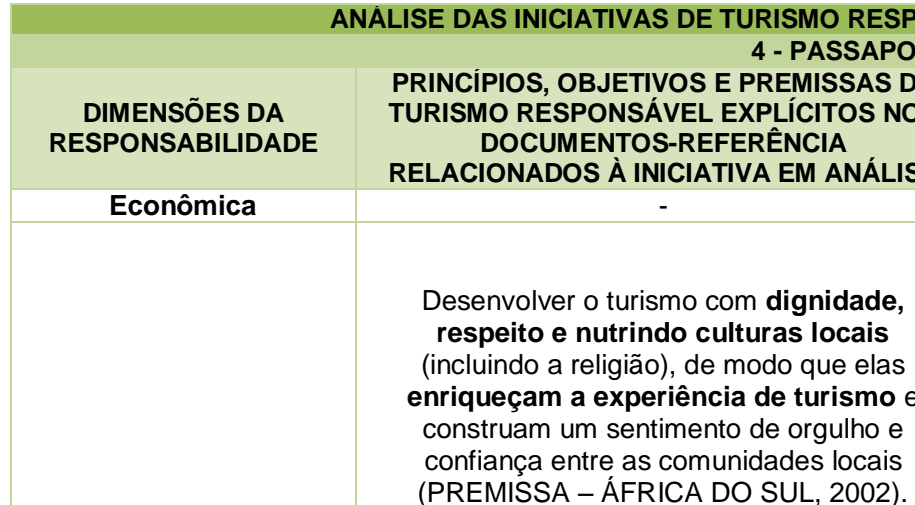

Incentivar os turistas a mostrarem respeito por aprender algumas palavras da língua local (e Social usá-las quando falar com os autóctones), e, ainda, a aprenderem sobre a cultura de acolhimento e tradições (PREMISSA - ÁFRICA DO SUL, 2002).

Ser sensível à cultura da comunidade receptora (OBJETIVO - ÁFRICA DO SUL, 2002). Educar os turistas sobre a cultura local e, se necessário, torná-los conscientes de como devem se comportar para respeitá-la (PREMISSA - AFRICA DO SUL, 2002). Desenvolver estratégias de promoção da igualdade de gêneros, etnias, idade e deficiência (PREMISSA - ÁFRICA DO SUL, 2002).

Adotar medidas para incentivar o comportamento que respeite o patrimônio natural e com baixo impacto sobre ele (PREMISSA - ÁFRICA DO SUL, 2002). Abordagem proativa do setor de turismo para com o meio ambiente, por meio da

promoção do turismo sustentável e equilibrado (PRINCÍPIO - ÁFRICA DO SUL, 2002).

Usar os recursos locais de forma sustentável (OBJETIVO - ÁFRICA DO SUL, 2002).

Ambienta

Adoção de medidas de redução do consumo de água e energia, reduzir a quantidade de resíduos produzidos, consumir alimentos produzidos localmente, incentivar o uso de transportes "amigos do ambiente” (PREMISSAS - ÁFRICA DO SUL, 2002).

Desenvolver e administrar o turismo de forma a garantir o mínimo impacto ambiental (GÂMBIA, 2002).

Adoção de medidas de redução do consumo de água e energia, reduzir a quantidade de resíduos produzidos, consumir alimentos produzidos localmente, incentivar o uso de transportes "amigos do ambiente" (PREMISSAS - ÁFRICA DO SUL, 2002).
EVIDËNCIAS DOS PRINCIPIOS, OBJETIVOS E PREMISSAS DE TURISMO RESPONSÁVEL DOS DOCUMENTOSREFERÊNCIA NA INICIATIVA EM ANÁLISE

"Apresentar aos turistas nacionais e internacionais experiências e maneiras diferenciadas de descobrir e vivenciar as cidades-sede e seu entorno com a incorporação de valores de consumo consciente. De maneira lúdica e através de vivências emblemáticas, estes roteiros possibilitam contribuir para o

desenvolvimento da cultura de um novo olhar dos turistas para os destinos" (OBJETIVOS DOS ROTEIROS PASSAPORTE VERDE)

"Trata-se simplesmente de uma forma de se desenhar circuitos e experiências turísticas a partir de valores."

"Características e valores dos roteiros:

- Mais diálogo e comunicação entre turista e comunidade local;

- Um aprendizado significativo sobre patrimônio cultural local

- Garanta interatividade real com associações e coletivos culturais e ambientais locais".

"Características e valores dos roteiros: - Valorização de iniciativas de inclusão social (acessibilidade, inclusão de projetos comunitários estruturados pelo SEBRAE)

"Características e valores dos roteiros:

- Um aprendizado significativo sobre o Bioma onde a cidade está localizada e visitação às Unidades de Conservação".

"Produção Sustentável: Sensibilização e preparo da cadeia produtiva do turismo das cidades-sede para padrões de produção mais sustentáveis usando o evento Copa do Mundo FIFA 2014 como catalizador" (OBJETIVOS DA CAMPANHA PASSAPORTE VERDE 2014). "Consumo Sustentável: Sensibilização e estímulo à adesão dos usuários da Copa praticantes de turismo a padrões de consumo mais sustentáveis através da experiência da Copa do Mundo FIFA 2014" (OBJETIVOS DA CAMPANHA PASSAPORTE VERDE 2014).

"Disseminação de práticas de ecoeficiência para o setor de turismo, com foco em bares, restaurantes e hotéis através de apresentação de conceitos, técnicas práticas, casos de sucesso e propostas de implantação com metas" (AÇÃO: JORNADAS DE SUSTENTABILIDADE NAS CIDADES-SEDE)

"Engajamento de entidades públicas e privadas para adoção de boas práticas" (AÇÃO: JORNADAS DE

SUSTENTABILIDADE NAS CIDADES-SEDE)

Temáticas - Ecoeficiência para hotéis, bares e restaurantes:

1- Consumo eficiente de energia 2 - Uso racional da água

3- Redução no desperdício de alimentos

4- Gestão de resíduos

5- RSC com o entorno

6- Engajamento dos Stakeholders

"Características e valores dos roteiros:

- Valorização de transporte público e/ou mobilidade de baixo carbono;

- Valorização da gastronomia local tradicional e locais de festa e alimentação popular e a alimentação de orgânicos: 
Pela observação do que foi exposto no item 6.2.4 desse capítulo, o qual descreve essa iniciativa, e com a análise feita no quadro apresentado anteriormente, percebe-se que essa campanha dialoga com as dimensões social e ambiental da responsabilidade.

Ao realizar uma análise do Quadro 07, fica evidente que o grande foco da campanha é a dimensão ambiental, isto é perceptível até mesmo pelo fato do próprio nome da campanha ser "Passaporte Verde". Entre os objetivos e as ações explicitadas, na terceira coluna de tal quadro, estão, por exemplo, a "sensibilização e preparo da cadeia produtiva do turismo (...) para padrões mais sustentáveis" e a "disseminação de práticas de ecoeficiência para o setor de turismo". Características da campanha que, como evidenciado no quadro em exame, promovem premissas ambientais da África do Sul, como o "incentivo ao comportamento que respeite o patrimônio natural" e a "abordagem proativa do setor de turismo para com o meio ambiente".

Além disso, ao verificar que ela tem o intuito de proporcionar aos turistas experiências e maneiras diferenciadas de se descobrir e vivenciar os destinos turísticos com a incorporação de valores de consumo consciente, como também contribuir para o desenvolvimento da cultura de um novo olhar dos turistas para os destinos, ousamos dizer que esta ação seria a que melhor incorpora um conceito que se mostra importante para o Turismo Responsável: de que o turismo deve ser desenvolvido com foco no ser humano e de maneira a contribuir para o local e ainda minimizar impactos negativos. A ideia de um desenvolvimento do turismo com valores éticos e morais, exercendo o respeito pelo o outro é subentendida na afirmação exposta no quadro: "Trata-se simplesmente de uma forma de se desenhar circuitos e experiências turísticas a partir de valores". Dessa forma, apesar do grande foco da campanha ser a dimensão ambiental da responsabilidade, ela consegue, também, abarcar de maneira importante, a dimensão social.

Diante dos aspectos analisados conclui-se que essa iniciativa envolve alguns princípios orientadores presentes na Declaração da Cidade do Cabo (2002). Um na dimensão social: "Ser sensível à cultura da comunidade local, mantendo e encorajando a diversidade social e cultural"; e quatro na dimensão ambiental: "Usar os recursos de forma sustentável, e reduzir o desperdício e o excesso de consumo", "Gerir a diversidade natural de forma sustentável e, quando apropriado restaurá-la; e considerar o volume e o tipo de turismo que o ambiente pode suportar, e respeitar a integridade 
dos ecossistemas vulneráveis e áreas protegidas", "Promover a educação e a conscientização para o desenvolvimento sustentável - para todos os stakeholders", "Aumentar o conhecimento de todos os stakeholders e garantir que as melhores práticas sejam seguidas (...)".

Vale destacar que, apesar da análise apresentada pelo quadro não apresentar nenhuma ligação dessa iniciativa com a responsabilidade econômica, visto que não foi achado nenhum ponto em comum dela com essa dimensão das políticas públicas da África do Sul e de Gâmbia, ao se verificar os princípios da Declaração da Cidade do Cabo (2002) conseguimos perceber que ela teria relação com um princípio que lá se apresenta nas orientações para a responsabilidade econômica: "Desenvolva o marketing turístico de modo a refletir a integridade natural, cultural e social do destino, e que incentive formas adequadas de turismo", visto que o portal da Campanha divulga e estimula a visitação a "roteiros sustentáveis", com foco na fomentação de destinos que valorizam e aproveitam os seus ativos naturais, culturais e sociais de maneira sustentável. De qualquer forma, aqui não a consideraremos responsável economicamente, já que nossa referência padrão segue de acordo com as políticas dos países estudados.

Quadro 08

Análise das iniciativas de Turismo Responsável do MTur - 05

\begin{tabular}{|c|c|c|}
\hline \multicolumn{3}{|c|}{ ANALISE DAS INICIATIVAS DE TURISMO RESPONSAVEL DO MINISTERIO DO TURISMO } \\
\hline \multicolumn{3}{|c|}{5 - VIAJA MAIS - MELHOR IDADE } \\
\hline $\begin{array}{c}\text { DIMENSÕES DA } \\
\text { RESPONSABILIDADE }\end{array}$ & $\begin{array}{c}\text { PRINCIPIOS, OBJETIVOS E } \\
\text { PREMISSAS DE TURISMO } \\
\text { RESPONSÁVEL EXPLÍCITOS NOS } \\
\text { DOCUMENTOS-REFERÊNCIA } \\
\text { RELACIONADOS À INICIATIVA EM } \\
\text { ANÁLISE }\end{array}$ & $\begin{array}{l}\text { EVIDÊNCIAS DOS PRINCÍPIOS, OBJETIVOS E } \\
\text { PREMISSAS DE TURISMO RESPONSÁVEL DOS } \\
\text { DOCUMENTOS-REFERÊNCIA NA INICIATIVA EM } \\
\text { ANÁLISE }\end{array}$ \\
\hline \multirow{3}{*}{ Econômica } & $\begin{array}{c}\text { Diminuir os impactos da } \\
\text { sazonalidade com o desenvolvimento } \\
\text { de novos produtos, ao se identificar e } \\
\text { estimular respostas comerciais para } \\
\text { novos mercados (PREMISSA, } \\
\text { ÁFRICA DO SUL, 2002). }\end{array}$ & $\begin{array}{c}\text { "Fortalecer o mercado interno, dinamizando a cadeia de } \\
\text { distribuição do turismo e proporcionando maior } \\
\text { estabilidade ao setor de serviços" (OBJETIVO } \\
\text { ESPECÍFICO - BRASIL, 2013b, p. 9). "Estimular a } \\
\text { atividade turística, principalmente em períodos de baixa } \\
\text { ocupação, como mecanismo de aumento da } \\
\text { competitividade dos destinos nacionais e redução dos } \\
\text { efeitos da sazonalidade" (OBJETIVO ESPECÍFICO - } \\
\text { BRASIL, 2013b, p. 9). }\end{array}$ \\
\hline & $\begin{array}{l}\text { Diminuir os impactos da sazonalidade } \\
\text { com o desenvolvimento de novos } \\
\text { produtos, ao se identificar e estimular } \\
\text { respostas comerciais para novos } \\
\text { mercados (PREMISSA, ÁFRICA DO } \\
\text { SUL, 2002). } \\
\text { Marketing e desenvolvimento de } \\
\text { produtos (OBJETIVO, ÁFRICA DO } \\
\text { SUL, 2002). }\end{array}$ & $\begin{array}{c}\text { "Estimular o aprimoramento e a diversificação dos } \\
\text { produtos turísticos já comercializados para o público } \\
\text { idoso". (OBJETIVO ESPECÍFICO - BRASIL, 2013b, p. 9). }\end{array}$ \\
\hline & $\begin{array}{l}\text { Fomento ao desenvolvimento de } \\
\text { oportunidades de acesso para todos } \\
\text { os visitantes e potenciais visitantes, } \\
\text { independente de suas condições } \\
\text { físicas ou mentais (PREMISSA, }\end{array}$ & $\begin{array}{l}\text { "Promover a inclusão social de pessoas com mais de } \\
60 \text { anos, de aposentados e de pensionistas, } \\
\text { proporcionando-lhes oportunidades de viajar e de usufruir } \\
\text { os benefícios da atividade turística, como forma de } \\
\text { fortalecimento do setor no Brasil" (OBJETIVO GERAL - }\end{array}$ \\
\hline
\end{tabular}




\begin{tabular}{|c|c|c|}
\hline & ÁFRICA DO SUL, 2002). & BRASIL, 2013b, p. 8). \\
\hline Social & $\begin{array}{c}\text { Garantir que todos os cidadãos } \\
\text { tenham igual acesso aos serviços } \\
\text { de turismo, tanto como consumidores } \\
\text { quanto como fornecedores } \\
\text { (PREMISSA - ÁFRICA DO SUL, } \\
\text { 2002). } \\
\text { Desenvolver estratégias de } \\
\text { promoção da igualdade de gêneros, } \\
\text { etnia, idade e deficiência (PREMISSA } \\
\text { - ÁFRICA DO SUL, 2002). }\end{array}$ & $\begin{array}{l}\text { "Fomentar viagens internas por meio de mecanismos que } \\
\text { viabilizem a oferta de produtos de qualidade e } \\
\text { acessíveis a idosos, aposentados e pensionistas" } \\
\text { (OBJETIVO ESPECÍFICO - BRASIL, 2013b, p. 9). } \\
\text { "Proporcionar ao público-alvo maior conhecimento do } \\
\text { país, de sua natureza, de sua cultura e de sua gente, } \\
\text { incentivando a cultura da viagem" (OBJETIVO } \\
\text { ESPECÍFICO - BRASIL, 2013b, p. 9). } \\
\text { "Estimular o desenvolvimento de um mercado turístico } \\
\text { segmentado para o público idoso, que permita uma } \\
\text { relação real entre qualidade e o preço dos serviços } \\
\text { turísticos" (OBJETIVO ESPECÍFICO - BRASIL, 2013b, p. } \\
9 \text { ). }\end{array}$ \\
\hline Ambiental & - & 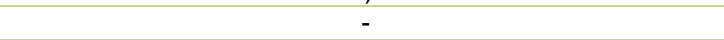 \\
\hline
\end{tabular}

Com as informações do Programa Viaja Mais - Melhor Idade, explicitadas no quadro anterior, e com sua explicação no item 6.2.5 desse Capítulo, é plausível assegurar que o Viaja Mais - Melhor Idade contempla tanto a responsabilidade econômica quanto a social.

Um dos grandes problemas que atingem o turismo é a sazonalidade. Ela afeta diretamente a sustentabilidade econômica dos destinos turísticos. A sazonalidade é um problema abordado pela premissa da África do Sul que diz que se deve: "diminuir os impactos da sazonalidade". Dessa forma, como evidenciado na terceira coluna do Quadro 08, essa iniciativa visa contribuir para diminuição dos impactos negativos causados pela referida dificuldade presente no turismo, ao incentivar que o público idoso viaje em períodos de baixa temporada, característica essa que se preocupa em resolver questões da dimensão econômica. Além disso, visa dinamizar "a cadeia de distribuição do turismo", proporcionar "maior estabilidade ao setor de serviços", e aprimorar e diversificar os produtos turísticos já comercializados para esse público.

Mas como já foi afirmado inicialmente, essa iniciativa não só se preocupa com a dimensão econômica, como também com a dimensão social. Ao mesmo tempo que busca solucionar problemas econômicos que atingem o turismo, promove a inclusão social ao disponibilizar a acessibilidade de produtos turísticos para esse público específico, que muitas vezes não possui condições de viajar e viver experiências no turismo. São esses fatores que justificam a afirmação que o Programa consegue contribuir com ambas dimensões da responsabilidade.

Vale ressaltar, também, que ao se analisar a Declaração da Cidade do Cabo (2002) fica claro que ele alcança o seguinte princípio norteador para a responsabilidade econômica "Desenvolver produtos de qualidade que refletem, complementam e 
melhoram o destino", pois há uma busca em se ofertar produtos turísticos diversificados aos ofertados a esse público normalmente. Além disso, ao verificarmos que o Viaja Mais - Melhor Idade busca "promover a inclusão social de pessoas com mais de 60 anos, de aposentados e de pensionistas, proporcionando-lhes oportunidades de viajar e de usufruir os benefícios da atividade turística, como forma de fortalecimento do setor no Brasil" (OBJETIVO GERAL, BRASIL, 2013b, p. 8), ele abarcaria de alguma forma o princípio orientador para a responsabilidade social da mesma declaração: "Esforçar-se para tornar o turismo uma experiência social inclusiva e para garantir que há acesso para todos, em especial as comunidades e indivíduos vulneráveis e desfavorecidos", visto que com as ofertas proporcionadas pelas empresas que participam dessa ação pode haver a inclusão de um público muitas vezes excluídos das prioridades da sociedade, o público da terceira idade.

Por último, ressalta-se que essa Campanha não apresenta informações explícitas que nos embase para afirmar o alcance da responsabilidade ambiental em seus objetivos, apesar de percebermos que possa haver estímulo a essa dimensão em seus desdobramentos, por exemplo, com a promoção de determinados produtos turísticos que incorpore a preocupação ambiental.

Quadro 09

Análise das iniciativas de Turismo Responsável do MTur - 06 ANÁLISE DAS INICIATIVAS DE TURISMO RESPONSAVEL DO MINISTERIO DO TURISMO 6 - TALENTOS DO BRASIL RURAL

PRINCIPIOS, OBJETIVOS E PREMISSAS DE \begin{tabular}{c|c} 
DIMENSÕES DA & TURISMO RESPONSÁVEL EXPLÍCITOS NOS \\
DOCUMENTOS-REFERÊNCIA RELACIONADOS
\end{tabular} RESPONSABILIDADE À INICIATIVA EM ANÁLISE

Fomento do empreendedorismo local e de oportunidades para os historicamente desfavorecidos, para a redução da pobreza, a geração de empregos e o desenvolvimento do mercado de trabalho e da economia local (PRINCÍPIO - ÁFRICA DO SUL, 2002).

Beneficiar-se da criação de serviços e produtos complementares, e com isso, tornar as, populações tradicionalmente menos favorecidas, como comunidades rurais e em situação de pobreza, fornecedoras desses produtos e serviços turísticos (PRINCÍPIO ÁFRICA DO SUL, 2002).

Suporte às comunidades locais, aos artesãos $e$ novos empreendedores no desenvolvimento de seus produtos e fomento do desenvolvimento de produtos turísticos de base comunitária (PREMISSAS - ÁFRICA DO SUL, 2002).

Maximizar os benefícios econômicos locais e garantir que as comunidades estejam envolvidas e se beneficiem com o turismo (OBJETIVOS EVIDËNCIAS DOS PRINCIPIOS, OBJETIVOS E
PREMISSAS DE TURISMO RESPONSÁVEL DOS
DOCUMENTOS-REFERÊNCIA NA INICIATIVA EM ANÁLISE

"Inserir produtos e serviços da agricultura familiar no mercado turístico, agregando valor à oferta turística brasileira". (OBJETIVO GERAL)

"- Conhecer e alinhar a oferta e a demanda do mercado turístico de produtos e serviços da agricultura familiar;

- Qualificar e agregar valor aos serviços e produtos da agricultura familiar existentes, para distribuição e comercialização no mercado turístico;

- Iniciar a preparação dos agricultores familiares para a prestação de serviços aos turistas e oferta de produtos diferenciados ao mercado turístico - em hotéis, bares, restaurantes, lojas de artesanato agregando valor socioambiental e sustentabilidade aos produto turístico;

- Apoiar a promoção e comercialização de produtos, serviços e destinos da agricultura familiar (OBJETIVOS ESPECÍFICOS).

"Qualificação dos empreendimentos e roteiros (consultoria para a formação de redes, roteirização turística, gestão de negócios, aperfeiçoamento de 


\begin{tabular}{|c|c|c|}
\hline & ÁFRICA DO SUL, 2002; GÂMBIA, 2002). & $\begin{array}{c}\text { produtos e geração de experiência e inovações); } \\
\text { Estudo de mercado (elaboração de Planos de } \\
\text { Posicionamento no Mercado); } \\
\text { Promoção e apoio à comercialização dos produtos e } \\
\text { serviços da agricultura familiar para o mercado } \\
\text { turístico" (AÇÕES DO PROGRAMA). }\end{array}$ \\
\hline & $\begin{array}{c}\text { Criar uma cadeia produtiva mais inclusiva, capaz } \\
\text { de demonstrar sua responsabilidade social e de } \\
\text { desenvolver e fornecer novos produtos de } \\
\text { qualidade que satisfaçam os interesses culturais e } \\
\text { de "conhecer pessoas" dos turistas (PRINCÍPIOS - } \\
\text { ÁFRICA DO SUL, 2002). } \\
\text { Manter e estimular a diversidade social e } \\
\text { cultural (OBJETIVO, ÁFRICA DO SUL, 2002; } \\
\text { GÂMBIA, 2002). }\end{array}$ & $\begin{array}{l}\text { "Inserir produtos e serviços da agricultura familiar } \\
\text { no mercado turístico, agregando valor à oferta turística } \\
\text { brasileira" (OBJETIVO GERAL- MTur e MDA, p.2, 2013). } \\
\text { "Agregar imagem de responsabilidade social e } \\
\text { ambiental; estabelecer relações mais diretas com } \\
\text { produtores; ofertar produtos que permitem a } \\
\text { diferenciação do equipamento - orgânicos, comércio } \\
\text { justo, biodiversidade; ofertar produtos saudáveis e de } \\
\text { qualidade". (VANTAGENS PARA O } \\
\text { EMPREENDIMENTO TURÍSTICO). }\end{array}$ \\
\hline Social & $\begin{array}{c}\text { Capacitação das comunidades para o comércio } \\
\text { de suas tradições e produtos culturais como } \\
\text { ativos e de melhorar suas oportunidades } \\
\text { econômicas (PREMISSA - ÁFRICA DO SUL, } \\
\text { 2002). } \\
\text { Construção de um sentimento de orgulho e } \\
\text { confiança entre as comunidades locais, por } \\
\text { meio do desenvolvimento do turismo com } \\
\text { dignidade, respeito e que nutra culturas locais e } \\
\text { que use o turismo como um catalisador para o } \\
\text { desenvolvimento humano (PREMISSAS, ÁFRICA } \\
\text { DO SUL, 2002). }\end{array}$ & $\begin{array}{c}\text { “(...) Qualificar e agregar valor aos serviços e } \\
\text { produtos da agricultura familiar existentes, para } \\
\text { distribuição e comercialização no mercado turístico; } \\
\text { - Iniciar a preparação dos agricultores familiares para } \\
\text { a prestação de serviços aos turistas e oferta de } \\
\text { produtos diferenciados ao mercado turístico - em } \\
\text { hotéis, bares, restaurantes, lojas de artesanato - na } \\
\text { Copa do Mundo de } 2014 \text {, agregando valor } \\
\text { socioambiental e sustentabilidade aos produto turístico; } \\
\text { - Apoiar a promoção e comercialização de produtos, } \\
\text { serviços e destinos da agricultura familiar" } \\
\text { (OBJETIVOS ESPECÍFICOS-MTur e MDA, p.2-3, 2013). }\end{array}$ \\
\hline Ambiental & $\begin{array}{l}\text { Usar os recursos locais de forma sustentável } \\
\text { (OBJETIVO, ÁFRICA DO SUL, 2002). } \\
\text { Estímulo ao consumo de alimentos produzidos } \\
\text { localmente (PREMISSA, ÁFRICA DO SUL, 2002). }\end{array}$ & $\begin{array}{c}\text { "Iniciar a preparação dos agricultores familiares para a } \\
\text { prestação de serviços aos turistas e oferta de produtos } \\
\text { diferenciados ao mercado turístico - em hotéis, bares, } \\
\text { restaurantes, lojas de artesanato - agregando valor } \\
\text { socioambiental e sustentabilidade aos produtos } \\
\text { turísticos" (OBJETIVO ESPECÍFICO). } \\
\text { "Agregar imagem de responsabilidade social e } \\
\text { ambiental; estabelecer relações mais diretas com } \\
\text { produtores; ofertar produtos que permitem a } \\
\text { diferenciação do equipamento - orgânicos, comércio } \\
\text { justo, biodiversidade; ofertar produtos saudáveis e de } \\
\text { qualidade". (VANTAGENS PARA O } \\
\text { EMPREENDIMENTO TURÍSTICO) } \\
\text { "Ter acesso a produtos com identidade regional, } \\
\text { produtos saudáveis, produtos com responsabilidade } \\
\text { social e ambiental, produtos com baixa emissão de } \\
\text { carbono" (VANTAGENS PARA O TURISTA) }\end{array}$ \\
\hline
\end{tabular}

Ao se pautar na apresentação das particularidades dessa iniciativa realizada no item 6.2.6 junto com os dados apresentados na análise esquemática mostrada no Quadro 09 - o qual destaca as evidências dos princípios, objetivos e premissas de Turismo Responsável dos documentos-referência na iniciativa Talentos do Brasil Rural - constatamos que ela se enquadra nas três dimensões da responsabilidade - na econômica, na social e na ambiental.

É claro perceber que ao se objetivar a qualificação e a agregação de valor aos serviços e produtos da agricultura familiar; a preparação dos agricultores familiares para a prestação de serviços aos turistas e para a oferta de produtos diferenciados ao mercado turístico com valor socioambiental e sustentabilidade aos produtos turísticos; e, ainda, o apoio à promoção e à comercialização de produtos, serviços e destinos da agricultura familiar; esse Projeto evidencia diversos princípios, objetivos e premissas 
expostos nas políticas de TR da África do Sul e de Gâmbia, tais como a maximização dos benefícios econômicos locais e a garantia que as comunidades locais estejam envolvidas e se beneficiem com o turismo (responsabilidade econômica), a capacitação das comunidades para o comércio de suas tradições e produtos culturais como ativos e de melhorar suas oportunidades econômicas com isso (responsabilidade social), e o uso dos recursos de forma sustentável (responsabilidade ambiental).

Em vista desses fatos, assim como as ações do TBC, entende-se que essa iniciativa envolve alguns princípios orientadores presentes na Declaração da Cidade do Cabo (2002), tais como: na dimensão econômica - "Maximizar os benefícios econômicos locais, aumentando as ligações e reduzindo vazamentos, assegurando que as comunidades estejam envolvidas e se beneficiando do turismo"; "Desenvolver produtos de qualidade que refletem, complementam e melhoram o destino"; "Desenvolver o marketing turístico de modo a refletir a integridade natural, cultural e social do destino, e que incentive formas adequadas de turismo"; na dimensão social "Ser sensível à cultura da comunidade local, mantendo e encorajando a diversidade social e cultural"; e na dimensão ambiental: "Usar os recursos de forma sustentável, e reduzir o desperdício e o excesso de consumo".

Em contrapartida, ainda que se tenha ressaltado o alcance das três dimensões da responsabilidade por essa ação, vale lembrar a existência de outros princípios orientadores da Declaração da Cidade do Cabo (2002) que poderiam ser incorporados para que esse projeto atuasse ainda com mais responsabilidade. Um princípio que seria importante para esse projeto, por exemplo, seria o de "adotar práticas comerciais equitativas, pagar e cobrar preços justos e construir parcerias de formas em que o risco seja minimizado e compartilhado, e recrutar e contratar pessoal reconhecendo normas trabalhistas internacionais", em vista que o comércio justo é uma reconhecida forma de valorizar e fortalecer os serviços e produtos rurais. 
Quadro 10

Análise das iniciativas de Turismo Responsável do MTur - 07

\begin{tabular}{|c|c|c|}
\hline \multicolumn{3}{|c|}{ ANÁLISE DAS INICIATIVAS DE TURISMO RESPONSAVEL DO MINISTERIO DO TURISMO } \\
\hline \multicolumn{3}{|c|}{7 - PROGRAMA DE REGIONALIZAÇĀO DO TURISMO } \\
\hline $\begin{array}{l}\text { DIMENSÕES DA } \\
\text { RESPONSABILIDADE }\end{array}$ & $\begin{array}{c}\text { PRINCIPIOS, OBJETIVOS E PREMISSAS DE } \\
\text { TURISMO RESPONSÁVEL EXPLÍCITOS NOS } \\
\text { DOCUMENTOS-REFERÊNCIA } \\
\text { RELACIONADOS À INICIATIVA EM ANÁLISE }\end{array}$ & $\begin{array}{l}\text { EVIDËNCIAS DOS PRINCIPIOS, OBJETIVOS E } \\
\text { PREMISSAS DE TURISMO RESPONSÁVEL DOS } \\
\text { DOCUMENTOS-REFERÊNCIA NA INICIATIVA EM } \\
\text { ANÁLISE }\end{array}$ \\
\hline Econômica & $\begin{array}{c}\text { Aumento da integração dos atores da cadeia } \\
\text { produtiva da área (PRINCÍPIO - ÁFRICA DO } \\
\text { SUL, 2002). } \\
\text { Maximizar os benefícios econômicos locais, } \\
\text { aumentar a integração dos atores } \\
\text { econômicos locais e reduzir as fugas de } \\
\text { capitais (OBJETIVOS - ÁFRICA DO SUL, } \\
\text { 2002; GÂMBIA, 2002). } \\
\text { Garantir que as comunidades estejam } \\
\text { envolvidas e se beneficiem com o turismo } \\
\text { (OBJETIVO - ÁFRICA DO SUL, 2002; } \\
\text { GÂMBIA, 2002). }\end{array}$ & $\begin{array}{c}\text { "Integração e participação social: fortalecendo o } \\
\text { protagonismo da cadeia produtiva do turismo no } \\
\text { âmbito regional, no conjunto dos municípios, e nos } \\
\text { processos de gestão das políticas públicas" (PREMISSA - } \\
\text { BRASIL, p.29, 2013d). } \\
\text { "Inclusão: entendendo a região como espaço plural e } \\
\text { participativo, que amplia as capacidades humanas e } \\
\text { institucionais, facilitando as relações políticas, } \\
\text { econômicas, sociais e culturais" (PREMISSA - BRASIL, } \\
\text { p.29, 2013d). } \\
\text { "Descentralização: atuando no âmbito do Sistema } \\
\text { Nacional de Turismo, adotando os métodos e processos } \\
\text { da Gestão Descentralizada" (PREMISSA - BRASIL, } \\
\text { p.29, 2013d). } \\
\text { "Apoiar a gestão, estruturação e promoção do turismo no } \\
\text { País, de forma regionalizada e descentralizada" } \\
\text { (OBJETIVO GERAL, BRASIL, p. 30, 2013d). } \\
\text { "Promover a integração e o fortalecimento das } \\
\text { instâncias colegiadas, nos Estados, regiões e } \\
\text { municípios, fortalecendo a Rede Nacional de } \\
\text { Regionalização" (OBJETIVO ESPECÍFICO, BRASIL, p.31, } \\
\text { 2013d). }\end{array}$ \\
\hline \multirow{4}{*}{ Econômica } & $\begin{array}{c}\text { Incentivo à elevação e à atualização de } \\
\text { padrões de serviços, especialmente de } \\
\text { pequenas, médias e microempresas } \\
\text { empreendedoras emergentes (PREMISSA, } \\
\text { ÁFRICA DO SUL, 2002). }\end{array}$ & $\begin{array}{c}\text { "Inovação: (...) uma nova visão integradora do } \\
\text { desenvolvimento produtivo e da competitividade, o } \\
\text { que: exige a formalização dos serviços e qualificação de } \\
\text { pessoas; provoca a ampliação dos micro e pequenos } \\
\text { empreendimentos, organizações associativas e } \\
\text { cooperativas; requer articulação em redes; demanda } \\
\text { investimentos em tecnologias (...)"(PREMISSA - } \\
\text { BRASIL, p.30, 2013d). } \\
\text { "Competitividade: entendida como a capacidade } \\
\text { crescente de gerar negócios nas atividades econômicas } \\
\text { relacionadas ao setor de turismo, de forma sustentável, } \\
\text { proporcionando ao turista uma experiência positiva”. } \\
\text { (PREMISSA - BRASIL, p.30, 2013d). } \\
\text { "Prover os meios para qualificar os profissionais e } \\
\text { serviços, bem como incrementar a produção associada } \\
\text { nas regiões e municípios turísticos. (OBJETIVO } \\
\text { ESPECíFICO - BRASIL, p.31, 2013d). } \\
\text { Fomentar o empreendedorismo nos estados, regiões e } \\
\text { municípios turísticos, bem como criar oportunidades para } \\
\text { a promoção de investimentos (OBJETIVO ESPECÍFICO, } \\
\text { BRASIL, p.31, 2013d). }\end{array}$ \\
\hline & $\begin{array}{l}\text { Incentivo à formalização do mercado informal } \\
\text { (PREMISSA, ÁFRICA DO SUL, 2002). }\end{array}$ & $\begin{array}{l}\text { "Inovação: (...) uma nova visão integradora do } \\
\text { desenvolvimento produtivo e da competitividade, o que: } \\
\text { exige a formalização dos serviços e qualificação de } \\
\text { pessoas;" (PREMISSA - BRASIL, p.30, 2013d). }\end{array}$ \\
\hline & $\begin{array}{l}\text { Suporte às comunidades locais, aos artesãos e } \\
\text { novos empreendedores no desenvolvimento de } \\
\text { seus produtos e fomento do desenvolvimento } \\
\text { de produtos turísticos de base comunitária } \\
\text { (PREMISSAS, ÁFRICA DO SUL, 2002). }\end{array}$ & $\begin{array}{l}\text { "Prover os meios para qualificar os profissionais e } \\
\text { serviços, bem como incrementar a produção associada } \\
\text { nas regiões e municípios turísticos" (OBJETIVO } \\
\text { ESPECĆFICO - BRASIL, p.30, 2013d). } \\
\text { "Qualificação profissional, dos serviços e da produção } \\
\text { associada: (...) levantar demanda de ações para o } \\
\text { fomento e integração da produção associada ao } \\
\text { turismo; organizar e qualificar a produção associada } \\
\text { ao turismo; definir estratégias para inserção dos } \\
\text { produtos e serviços de base local" (EIXO DE } \\
\text { ATUAÇÂO, BRASIL, p. 35-36, 2013d). }\end{array}$ \\
\hline & $\begin{array}{c}\text { Marketing e desenvolvimento de produtos } \\
\text { (OBJETIVO - ÁFRICA DO SUL, 2002; } \\
\text { GÂMBIA, 2002). }\end{array}$ & $\begin{array}{l}\text { "Apoiar a promoção e comercialização dos produtos } \\
\text { turísticos" (OBJETIVO ESPECÍFICO, p.30, 2013d). } \\
\text { "Planejamento e posicionamento de mercado: a partir } \\
\text { de dados e informações coletadas, subsidiar o } \\
\text { planejamento e desenvolvimento de produtos }\end{array}$ \\
\hline
\end{tabular}




\begin{tabular}{|c|c|c|}
\hline \multicolumn{3}{|c|}{$\begin{array}{c}\text { ANÁLISE DAS INICIATIVAS DE TURISMO RESPONSAVEL DO MINISTERIO DO TURISMO } \\
7 \text { - PROGRAMA DE REGIONALIZAÇAO DO TURISMO }\end{array}$} \\
\hline $\begin{array}{c}\text { DIMENSÕES DA } \\
\text { RESPONSABILIDADE }\end{array}$ & $\begin{array}{l}\text { PRINCIPIOS, OBJETIVOS E PREMISSAS DE } \\
\text { TURISMO RESPONSÁVEL EXPLÍCITOS NOS } \\
\text { DOCUMENTOS-REFERÊNCIA } \\
\text { RELACIONADOS À INICIATIVA EM ANÁLISE }\end{array}$ & $\begin{array}{l}\text { EVIDËNCIAS DOS PRINCIPIOS, OBJETIVOS E } \\
\text { PREMISSAS DE TURISMO RESPONSÁVEL DOS } \\
\text { DOCUMENTOS-REFERÊNCIA NA INICIATIVA EM } \\
\text { ANÁLISE }\end{array}$ \\
\hline & & $\begin{array}{c}\text { turísticos (destinos, roteiros, serviços) a partir de } \\
\text { elementos de identidade da oferta turística, observadas, } \\
\text { também as características da demanda (público-alvo) } \\
\text { (...)".(EIXO DE ATUAÇÃO, BRASIL, p. 35, 2013d). } \\
\text { "Promoção e apoio à comercialização: este eixo exige } \\
\text { profissionais e serviços qualificados, infraestrutura, } \\
\text { informações seguras e precisas, articulação da cadeia } \\
\text { produtiva do turismo em redes de cooperação, de forma a } \\
\text { se obter produtos estruturados e segmentados, } \\
\text { adequados à promoção e comercialização" (EIXO DE } \\
\text { ATUAÇÃO, BRASIL, p. 37, 2013d). }\end{array}$ \\
\hline Social & $\begin{array}{c}\text { Envolver a comunidade local no } \\
\text { planejamento e na tomada de decisão } \\
\text { (OBJETIVO, ÁFRICA DO SUL, 2002). } \\
\text { Incentivar a participação proativa e o } \\
\text { envolvimento de todas as partes } \\
\text { interessadas - incluindo o setor privado, o } \\
\text { governo em todos os níveis, a cadeia produtiva } \\
\text { e as comunidades locais (seus líderes e } \\
\text { estruturas) - em todas as fases do ciclo de vida } \\
\text { do turismo. (PREMISSA, ÁFRICA DO SUL, } \\
\text { 2002). } \\
\text { Assegurar-se que as comunidades participem } \\
\text { ativamente no monitoramento dos impactos } \\
\text { sociais advindos do turismo. (PREMISSA, } \\
\text { ÁFRICA DO SUL, 2002). } \\
\text { Encorajar a participação de todos os } \\
\text { stakeholders, dos setores formais e informais, } \\
\text { governo e comunidade; envolver a } \\
\text { comunidade local criando oportunidades para } \\
\text { que se engaje no processo de planejamento } \\
\text { para o desenvolvimento do turismo. (GÂMBIA, } \\
\text { 2002) }\end{array}$ & $\begin{array}{c}\text { “O modelo de gestão adotado pelo Programa de } \\
\text { Regionalização do Turismo está alicerçado sob a ótica da } \\
\text { gestão compartilhada, deixando evidente a } \\
\text { participação, democratização, consensos e acordos, } \\
\text { envolvendo multiplicidade e diversidade de entes } \\
\text { institucionais, agentes econômicos e sociedade civil } \\
\text { organizada. } \\
\text { Traduz as aspirações da sociedade e do governo na } \\
\text { corresponsabilidade na tomada de decisão, na } \\
\text { formulação de estratégias, na determinação das } \\
\text { prioridades de execução, na avaliação, que referendem } \\
\text { os objetivos a serem alcançados na perspectiva da } \\
\text { inclusão e do desenvolvimento. } \\
\text { Outra centralidade da gestão do Programa de } \\
\text { Regionalização do Turismo são os meios de acesso para } \\
\text { a transparência e o compartilhamento das informações } \\
\text { e resultados da execução da política (...)”. (BRASIL, p. 31- } \\
\text { 32, 2013d). }\end{array}$ \\
\hline Ambiental & $\begin{array}{l}\text { Abordagem proativa do setor de turismo para } \\
\text { com o meio ambiente, por meio da promoção } \\
\text { do turismo sustentável e equilibrado } \\
\text { (PRINCÍPIO - ÁFRICA DO SUL, 2002). }\end{array}$ & $\begin{array}{l}\text { "Sustentabilidade, compreendendo o desenvolvimento } \\
\text { sustentável das regiões turísticas como base para a } \\
\text { preservação da identidade cultural, respeitando as } \\
\text { especificidades políticas, econômicas, sociais e } \\
\text { ambientais" (PREMISSA, BRASIL, p.29, 2013d). }\end{array}$ \\
\hline
\end{tabular}

O Programa de Regionalização foi apresentado no item 4.4 dessa dissertação quando descrevemos o histórico das políticas públicas de turismo no Brasil, pois esse Programa é resultado da forma de gestão adotada pelo MTur - a descentralização.

Com as informações oferecidas em tal tópico e com o que foi exibido no item 6.2.7 desse capítulo, o qual descreve essa iniciativa, junto com os dados revelados no Quadro 10, observa-se que o PRT conversa com todas as dimensões da responsabilidade e se apresenta como um sólido Programa no que diz respeito ao alcance de princípios, objetivos e premissas do Turismo Responsável. Isso pode ser afirmado, porque como foi exposto, esse Programa abarca diversos pontos estruturantes para se desenvolver o turismo de maneira responsável. É um programa 
completo com fortes aspectos de responsabilidade econômica e social, mas também almeja ações na ambiental.

Esse fato é demonstrado levando-se em consideração que a responsabilidade econômica é abraçada pelo Programa, por exemplo, ao se fortalecer o protagonismo da cadeia produtiva do turismo com integração e participação social e ao se facilitar as relações políticas, econômicas, sociais e culturais com a inclusão da região como espaço plural e participativo e com o fortalecimento de uma rede nacional que envolve estados, regiões e municípios. Além do mais, o PRT tem como premissa a inovação e a competitividade, e como objetivos qualificar os profissionais e serviços e fomentar o empreendedorismo. Tudo isso, conforme demonstrado no quadro de análise, evidencia o aumento da integração dos atores da cadeia produtiva da área (ÁFRICA DO SUL, 2002); a maximização dos benefícios econômicos locais, e aumento da integração dos atores econômicos (ÁFRICA DO SUL, 2002; GÂMBIA, 2002); e a garantia que as comunidades estejam envolvidas e se beneficiem com o turismo (ÁFRICA DO SUL, 2002; GÂMBIA, 2002).

Ao mesmo tempo, a responsabilidade social também é abrangida, por exemplo, ao se verificar que o modelo de gestão tomado pelo PRT - que está fundamentado sob a visão da gestão compartilhada que propaga a participação, a democratização, os consensos e acordos, ao envolver a multiplicidade e diversidade de entes institucionais, agentes econômicos e sociedade civil organizada; como também, "traduz as aspirações da sociedade e do governo na corresponsabilidade na tomada de decisão, na formulação de estratégias, na determinação das prioridades de execução, na avaliação" (BRASIL, 2013d, p. 31-32) - consegue envolver a comunidade local no planejamento e na tomada de decisão (ÁFRICA DO SUL, 2002); incentivar a participação proativa e o envolvimento de todas as partes interessadas - incluindo o setor privado, o governo em todos os níveis, a cadeia produtiva e as comunidades locais (seus líderes e estruturas) - em todas as fases do ciclo de vida do turismo (ÁFRICA DO SUL, 2002), e assegura que as comunidades participem ativamente no monitoramento dos impactos sociais advindos do turismo (ÁFRICA DO SUL, 2002), além de encorajar a participação de todos os stakeholders, dos setores formais e informais, governo e comunidade e envolver a comunidade local ao se criar oportunidades para que ela se engaje no processo de planejamento para o desenvolvimento do turismo (GÂMBIA, 2002). 
Igualmente, há também uma preocupação com a responsabilidade ambiental, já que a sustentabilidade, no que compreende "o desenvolvimento sustentável das regiões turísticas como base para a preservação da identidade cultural, respeitando as especificidades políticas, econômicas, sociais e ambientais" é uma premissa desse Programa (BRASIL, 2013d, p.29).

Dado o exposto, entende-se que essa iniciativa responde, também, a princípios orientadores presentes na Declaração da Cidade do Cabo (2002) para as três dimensões da responsabilidade. Na econômica, a maximização dos benefícios econômicos locais, com o aumento das ligações locais e garantia do envolvimento das comunidades no processo e se beneficiando do turismo. Na social, ao envolver ativamente a comunidade local no planejamento e na tomada de decisões e fornecer capacitação para tornar isso uma realidade. E na ambiental, ao buscar a promoção, para todos os stakeholders, da educação e da conscientização para o desenvolvimento sustentável.

Após a exposição da análise de cada iniciativa responsável do MTur, foi possível elaborar um quadro-resumo, apresentado a seguir no Quadro 11, que identifica de forma esquemática quais as dimensões que cada iniciativa abrange. Isso foi feito para se ter uma ideia geral de quais dimensões são mais contempladas pelo órgão, bem como quais ainda não possuem muitas correspondências. Da mesma forma, ressaltam-se quais as iniciativas seriam mais completas por abarcar todas as dimensões.

Quadro 11

Alcance da responsabilidade pelas iniciativas do MTur

\begin{tabular}{|c|c|c|c|}
\hline \multicolumn{5}{|c|}{$\begin{array}{c}\text { QUADRO-RESUMO DAS DIMENSOES DA RESPONSABILIDADE ABARCADAS PELAS INICIATIVAS DO } \\
\text { MTUR }\end{array}$} \\
\hline INICIATIVAS DO MTUR & $\begin{array}{c}\text { RESPONSABILIDADE } \\
\text { ECONÔMICA }\end{array}$ & $\begin{array}{c}\text { RESPONSABILIDADE } \\
\text { SOCIAL }\end{array}$ & $\begin{array}{c}\text { RESPONSABILIDADE } \\
\text { AMBIENTAL }\end{array}$ \\
\hline $\begin{array}{c}\text { Programa Turismo } \\
\text { Sustentável e Infância }\end{array}$ & $\mathbf{X}$ & $\mathbf{X}$ & $\mathbf{X}$ \\
\hline Turismo de Base Local & $\mathbf{X}$ & $\mathbf{X}$ & $\mathbf{X}$ \\
\hline Programa Turismo Acessível & $\mathbf{X}$ & $\mathbf{X}$ & \\
\hline Campanha Passaporte Verde & $\mathbf{X}$ & $\mathbf{X}$ \\
\hline $\begin{array}{c}\text { Programa Viaja Mais - Melhor } \\
\text { Idade }\end{array}$ & $\mathbf{X}$ & $\mathbf{X}$ & $\mathbf{X}$ \\
\hline $\begin{array}{c}\text { Programa de Regionalização } \\
\text { do Turismo }\end{array}$ & $\mathbf{X}$ & $\mathbf{X}$ & \\
\hline $\begin{array}{c}\text { Programa Talentos do Brasil } \\
\text { Rural }\end{array}$ & $\mathbf{F}$ & & \\
\hline
\end{tabular}

Fonte: Elaborado pela autora. 
Pela a observação do Quadro 11, constata-se que a responsabilidade social é sem dúvida a dimensão mais atingida - é abarcada por todas as iniciativas - enquanto que a ambiental é a menos alcançada, uma vez que, de sete ações, somente quatro abordam-na. Além disso, verificou-se que menos da metade das iniciativas responsáveis (somente três) envolvem todas as três dimensões e apenas uma atinge uma única dimensão - o Programa Turismo Sustentável e Infância.

Por meio da análise realizada nesse capítulo, foi possível perceber que apesar do Ministério do Turismo não possuir uma Política Nacional de Turismo Responsável, de forma geral o órgão demonstra incorporar a responsabilidade em algumas de suas ações, mesmo que não a abarcando em todas as suas dimensões, e, ainda, busca promover uma gestão descentralizada que, como foi explicado, envolve diversos princípios do TR.

Entretanto, essas iniciativas são trabalhadas separadamente, isto é, não há ainda uma interação entre elas para oferecer resultados sinérgicos aos destinos turísticos e suas comunidades locais. Tal fato é reflexo das desvantagens do TR ser trabalhado em ações pontuais sem a sua inserção como diretriz básica de todo o trabalho desenvolvido pelo MTur.

Por fim, destaca-se que alguns princípios, objetivos e premissas importantes para o fomento do TR - como, por exemplo, os princípios que envolvem as questões de avaliação dos impactos econômicos, sociais e ambientais durante todo o ciclo de fomento e desenvolvimento e a preocupação em adotar práticas comerciais equitativas, com pagamento de preços justos - parecem ainda não ser preocupação da gestão pública federal do turismo. 
7 A RESPONSABILIDADE NA VISÃO DOS GESTORES DO MINISTÉRIO DO TURISMO

Se todo mundo está pensando igual, então alguém não está pensando.

Seneral Patton 
Para essa discussão foi considerada a visão de alguns gestores públicos federais de Turismo em atuação no MTur para dialogar sobre a percepção do Turismo Responsável e sua importância para a construção das políticas elaboradas em âmbito nacional.

Contou-se aqui com entrevistas realizadas com gestores elegidos de forma oportuna, não probabilística e por acessibilidade. Foram aplicadas entrevistas semiestruturadas, sem limite de tempo para as respostas. O roteiro de entrevista foi composto por 5 (cinco) perguntas abertas e as questões abordaram o conhecimento sobre Turismo Responsável, bem como sobre iniciativas que, na visão do entrevistado, poderiam estar conectadas com o tema.

As entrevistas foram concretizadas no período de novembro de 2013 a janeiro de 2014. Foram entrevistados 10 (dez) profissionais do MTur, entre os quais estão 2 (dois) Diretores, 2 (dois) Coordenadores e 6 (seis) Coordenadores - Gerais de departamentos pertencentes às três Secretarias existentes na estrutura administrativa do MTur (Secretaria Executiva, Secretaria Nacional de Políticas de Turismo e Secretaria Nacional de Programas de Desenvolvimento do Turismo). Sendo assim, todos os entrevistados pertencem a cargos ligados ao planejamento, ao desenvolvimento e à implantação de políticas públicas de turismo.

As cinco questões desenvolvidas para o roteiro de entrevista foram concentradas nos seguintes assuntos: familiaridade e conhecimento com o termo e o conceito de Turismo Responsável; importância da discussão sobre o tema e sua inserção no MTur; e as iniciativas correlacionadas ao tema. Além desses assuntos, os gestores também foram questionados sobre os possíveis entraves e/ou dificuldades para se implantar uma política de Turismo Responsável no Ministério do Turismo.

Vale lembrar que as respostas dos entrevistados foram interpretadas por uma abordagem predominantemente qualitativa, porém quando se achou importante e apropriado para a apresentação do diagnóstico, foram feitas algumas observações quantitativas, com a informação, por exemplo, de quantos entrevistados tinham respostas similares e quantos divergiam. Por serem gestores públicos optou-se por deniminar os entrevistados por: G1, G2, G3, G4, G5, G6, G7, G8, G9 e G10.

Além disso, como explicado anteriormente no primeiro capítulo dessa dissertação, foram aplicadas as técnicas de entrevista em profundidade para a 
execução da pesquisa de campo; assim como a análise de conteúdo, para desenvolver a crítica sobre o material coletado.

Em seguida serão apresentados os resultados dessa pesquisa, com suas principais perguntas e respostas, e respectivas análises.

\subsection{PERCEPÇÕES SOBRE TURISMO RESPONSÁVEL PELOS GESTORES PÚBLICOS FEDERAIS DO MINISTÉRIO DO TURISMO}

Ao considerar que um tema para ser introduzido nas políticas públicas de qualquer área precisa ser primeiramente apropriado pelos formuladores destas e, posteriormente, ser percebido como fundamental para o setor, surgiu o objetivo de se pesquisar a familiaridade dos gestores com o tema e o conhecimento do conceito de Turismo Responsável por estes. Para se alcançar esse objetivo, foram utilizadas 3 (três) perguntas.

A primeira pergunta foi: Você já ouviu falar sobre Turismo Responsável? Teve-se com ela a intenção de verificar a familiaridade dos entrevistados com o termo "Turismo Responsável" para que adicionada à segunda pergunta pudesse ser verificado qual o conhecimento deles sobre o assunto.

Observou-se que a grande maioria dos entrevistados já ouviu falar sobre Turismo Responsável. Dos dez entrevistados, somente dois não deram uma resposta positiva a essa pergunta, sendo que um (G3) afirmou categoricamente nunca ter ouvido falar: "Nunca falaram. Aqui no Ministério então, nunca se falou disso"; e o outro (G5) disse nunca ter ouvido particularmente no termo. Este respondeu "não com esse termo específico".

De acordo com as respostas foi possível perceber que alguns, talvez, demonstram familiaridade com o termo por associá-lo à responsabilidade no planejamento do turismo, uma vez que a própria palavra "Responsável", parte integrante da nomenclatura "Turismo Responsável" já indica sobre o quê esse "turismo" pode estar tratando. Por exemplo, quando o entrevistado G10 afirma "desde estudante eu ouço falar de Turismo Responsável, mas não necessariamente com essa expressão"; pois quando se trata da teoria de Turismo é comum a menção e preocupação com um planejamento do turismo e de um desenvolvimento com responsabilidade. 
Apesar de oito gestores responderem positivamente à pergunta, quatro respondem somente com um "sim" ou um "já", o que nos indica conferir se realmente sabem do que se trata o conceito apenas com a segunda pergunta. $O$ restante, quatro entrevistados, já tentam explicar o que seria o conceito. Destes, metade associa o TR com as ideias pertencentes à sustentabilidade, como comprovado nos seguintes trechos: G7: '[...] associação da atividade econômica 'turismo' com as temáticas da sustentabilidade, que dizem respeito à responsabilidade com os temas de meio ambiente, sociedade e economia"; e G9: "Já. O nosso (programa), por exemplo, Turismo Sustentável e Infância, nós enquadramos como turismo responsável, nessa conceituação". Uma pessoa (G10) relaciona - o com Turismo Social, ou turismo com responsabilidade social: "Já. [...] Mas ele sempre foi tratado dentro do tema do Turismo Social. [...]".

O único entrevistado (G1) que afirma com muita clareza já ter tido contato especificamente com esse termo, justifica esse conhecimento por ter conversado com uma pessoa que estava estudando o termo, pois participava da construção de um programa de TR. Assim, esse entrevistado conseguiu demonstrar a absorção de princípios importantes do TR, como a preocupação com a inclusão no turismo de todos os tipos de pessoas independente de sua idade ou de sua classe social, e ainda associa-o à ideia de respeito e cuidado:

G1: (...) é aquela questão de você trabalhar um Turismo com foco em questões que mereçam ser respeitadas, que é a história do turismo da melhor idade, o turismo de algumas questões de minorias, o LGBT, o Turismo com jovem. (...) Então tudo isso forma um conjunto de atividades ou segmentos que merecem que a gente tenha um turismo responsável, de mais foco, de mais atenção, de mais cuidado.

Porém, apesar de ter sido o único que expressou claramente o contato com o correto termo, não mencionou em nenhum momento as outras dimensões da responsabilidade - a econômica e a ambiental; e explicita entender o termo como uma associação de segmentos, o que exclui seu real significado de uma diretriz, sua transversalidade, e que o TR deve ser o pilar de todo e qualquer tipo de turismo, ao invés de ser pensado somente para segmentos específicos.

Sobre esse assunto podemos destacar a fala do G10, o único que já expressa nessa primeira pergunta a percepção da transversalidade do Turismo Responsável: 
"mesmo sem se posicionar como um não segmento, o Turismo Responsável, o Turismo Sustentável, isso foi trabalhado aqui dentro da segmentação por ser transversal a todos os segmentos".

É interessante destacar que um gestor (G10) afirma que o TR sempre foi trabalhado no MTur, porém com outros termos: "Aqui no âmbito do MTur esse tema sempre foi tratado. (...) o Ministério nunca adotou a expressão 'Turismo Responsável', mas dentro de outros temas sempre foi trabalhado".

A segunda pergunta feita foi: Sabe o que significa Turismo Responsável? Nessa pergunta todos tentaram explicar o significado de TR, e ainda expuseram fragmentos do conceito. Não houve nenhuma resposta que pudéssemos afirmar estar totalmente desconexa com o conceito do termo, contudo não houve também nenhuma que englobasse completamente o conceito.

As respostas podem ser dividas em dois grupos com ideias similares. Um seria o grupo com respostas que abordaram a preocupação com a minimização dos impactos negativos do turismo (G1, G3, G6, G7 e G8). O outro (G1, G2, G5, G9 e G10) com a associação do conceito de TR ao de Turismo Sustentável, como algo similar a este ou como sinônimos. Os dois grupos possuem a mesma quantidade de pessoas, sendo que o G1 entraria nos dois e o G4 em nenhum deles, pois apresentou resposta que não se enquadra adequadamente ao foco de respostas dos grupos.

Esse primeiro grupo apresenta conceitos ligados a uma das características do TR apresentada na Declaração da Cidade do Cabo (2002) - "Minimiza os impactos negativos sociais, econômicos e ambientais"; como pode ser visto nas seguintes falas: G6: "Um conjunto de ações pensadas para minimização dos impactos da atividade turística nas regiões e nos próprios destinos, sejam esses impactos na própria natureza, ou na cultura da comunidade, enfim no dia a dia da comunidade"; G8: "Na verdade, eu imagino que seja um conjunto de ações que visam maximizar o desenvolvimento do turismo nos destinos, no econômico, social e ambiental. E minimizar os impactos negativos".

É válido notar que a preocupação com os impactos sociais / culturais e com os ambientais é citada por todos os cinco entrevistados pertencentes a esse grupo de respostas, no entanto, somente dois gestores, o G7 e o G8 (como poderá ser comprovado nos trechos mostrados abaixo) citam as três dimensões, eles mencionam impactos tanto na área ambiental e social/cultural como na área econômica - 
esquecida pela maioria dos entrevistados. Fato que pode indicar que os princípios, os objetivos e as premissas da dimensão econômica não são tão fáceis de serem compreendidos/assimilados, ou vistos como importantes por esses gestores públicos quanto os das dimensões social e ambiental, quando se trata do olhar sobre o Turismo Responsável.

G7: [...] Precisa-se cada vez mais tentar utilizar a forma de desenvolvimento e crescimento econômico dentro de uma estratégia ambientalmente correta. E no caso do Turismo você tem uma série de frentes que podem ser desenvolvidas. Acho que o Turismo Responsável/Sustentável é a melhor representação dessa frente. Mas eu sempre faço a associação dos três: econômico, social e ambiental para o setor do turismo, e é isso que eu definiria como Turismo Responsável.

G8: Na verdade eu imagino que seja um conjunto de ações que visam maximizar o desenvolvimento do turismo nos destinos, no econômico, social e ambiental. E minimizar os impactos negativos.

Já o grupo dois, na divisão de nossa análise, é o que indica o conceito de TR relacionado claramente com a sustentabilidade, como pode ser conferido nos seguintes trechos:

G2: Turismo Responsável é um turismo com sustentabilidade, para que haja continuidade, para que as coisas sejam sustentáveis e passem de geração em geração.

G5: Alguma coisa de sustentabilidade econômica e social. Associo a isso.

G10: E uma forma responsável de se trabalhar o turismo, seja lá por meio da sustentabilidade ambiental, por meio da preservação e conservação do meio ambiente, seja lá por meio da sustentabilidade cultural, trabalhando ali o multiculturalismo e a preservação da cultura de forma geral. [...] Eu penso que o nome já diz, tem que ser responsável, tem que ser responsável socialmente falando, tem que ser responsável culturalmente falando, ambientalmente falando, e aí para cada uma dessas vertentes tem se um mundo de coisas a se trabalhar de forma responsável, muitas vezes podemos utilizar para essas vertentes a palavra sustentável.

Nesse grupo foram observados pontos significativos na fala do G9. Ele é o único que ressalta a ligação do TR com a garantia de Direitos Humanos e a importância de se pensar em pontos além de ganhos financeiros do turismo como atividade econômica. Ele deixa sobressair em seu discurso a importância de valores como o respeito e ainda a seriedade de preocupações sociais quando se trata do desenvolvimento do turismo com responsabilidade, ou para ele, com sustentabilidade, como se pode ver a seguir: 
G9: Eu acredito que seja um turismo plantado em cima de condições básicas e importantes, como por exemplo, direito à vida, direito à saúde. As garantias dos Direitos Humanos. Eu entendo assim, a partir do momento que eu encaro a sustentabilidade como algo que deve ser corretamente utilizado e também as atividades que não haja interferência em cultura [...]. Então eu ligaria junto com alguns valores, alguns princípios que a gente tem na nossa cadeia turística e também com algumas questões do relacionamento do turista com a comunidade, com a sociedade. [...] $O$ turismo não é só uma atividade econômica, ele tem que caminhar passo a passo também com essas questões socias $[\ldots]$.

Observou-se também, que o G9 é a única pessoa que cita algo que vai ao encontro da seguinte característica do TR: "É culturalmente sensível, estimulando o respeito entre turistas e anfitriões, fortalecendo a confiança e o orgulho locais" (Declaração da Cidade do Cabo, 2002); pois, como é possível ser visto em sua resposta, cita o respeito e a relação do turista com a comunidade anfitriã.

Destaca-se que, apesar do TR ser visto de uma maneira equivocada por essa pessoa no que diz respeito a sua transversalidade, já que o enxerga como um segmento ou como um conjunto de alguns segmentos, o G1 consegue formular um conceito que se insere nos dois grupos, uma vez que se refere a se preocupar com a "exploração" do turismo atenta aos limites dos recursos (ligação com a sustentabilidade), e a uma abordagem do turista que minimize os impactos de sua visitação, como pode ser conferido em sua resposta transcrita a seguir:

G1: Do ponto de vista de um segmento acredito que deve haver políticas, programas, enfim, projetos que pensem em explorar a atividade turística, contudo respeitando os limites dos recursos naturais, culturais e sociais que existem nos destinos. E do ponto de vista do turista, eu imagino que seja um conceito que leve essas pessoas a terem atos nas suas viagens que não impactem tanto na sua visitação, ou que tenham um tipo de consciência no ato de visitar um lugar.

O único entrevistado que não se insere a nenhum dos dois grupos de resposta é o G4. Sua explicação do conceito de TR concentra-se no desenvolvimento do turismo de forma que gere benefícios para a comunidade local. Segundo ele, "Turismo Responsável é você investir em projetos que tragam benefícios para a comunidade [...] que consiga desenvolver o turismo, mas de forma responsável que beneficie a comunidade". Este conceito pode ser associado a um objetivo da dimensão social da responsabilidade constante tanto na política da África do Sul (2003), quanto de Gâmbia (2003): "Garantir que as comunidades estejam envolvidas e se beneficiem do turismo". E, ainda, poderíamos dizer que é um conceito que absorve uma das características do 
TR de acordo com a Declaração da Cidade do Cabo (2002): "Gera mais benefícios econômicos para a população local e melhora o bem-estar das comunidades receptoras, melhorando as condições de trabalho e o acesso ao mercado de trabalho".

Observou-se, também, que questões como o envolvimento da comunidade no planejamento e na tomada de decisão, o comprometimento de todos os stakeholders em práticas responsáveis ou, ainda, a garantia de igual acesso a todos os cidadãos, e por fim a acessibilidade não é lembrada por ninguém. E esses são pontos muito citados tanto na teoria sobre Turismo Responsável, quanto na prática - nas políticas da África do Sul e de Gâmbia, e até mesmo nas preocupações de iniciativas do próprio ministério, como no Programa de Regionalização do Turismo e no Turismo Acessível.

Apesar disso, as falas dos entrevistados podem ser avaliadas de maneira geral de forma positiva, pois nenhum formulou conceitos do TR com discursos contrários aos seus princípios. O que ficou claro foi que os gestores não possuem conhecimento das características completas, de todos os princípios e de todas as premissas que ele envolve, porém, têm uma ideia geral do conceito.

As respostas a essa segunda pergunta estão estritamente relacionadas as da terceira pergunta, a qual foi: Acredita que Turismo Sustentável tenha o mesmo significado que Turismo Responsável?

Como já foi explicado nesse trabalho, Turismo Responsável e Turismo Sustentável são conceitos próximos, porém não são iguais. A intenção dessa pergunta foi verificar principalmente se o Turismo Sustentável é percebido como um conceito etéreo, e ao mesmo tempo constatar se o termo Turismo Responsável seria relacionado mais à prática. Ao mesmo tempo, averiguar se os entrevistados citariam a maior diferença entre os dois conceitos segundo Goodwin (2012): a essencialidade do papel de todos (indivíduos, organizações e empresas) para a construção da responsabilidade no turismo - à medida que no Turismo Responsável todos são convidados a assumirem a responsabilidade por suas ações e os impactos causados por estas.

Ao se analisar as falas, percebemos que nenhuma pessoa conseguiu dar a resposta exata. A maioria demonstrou incertezas (G2, G3 e G7: "eu acho que"; G5: "Poderia ser um sinônimo, como eu nunca ouvi nem nunca me interessei particularmente pelo assunto (...) acho que"); ou afirmou não ter conhecimento para responder com exatidão - G1: "não tenho clareza"; G6: "Eu tenho pouco conhecimento 
do assunto". O restante (G4, G8, G9 E G10) afirmou que os conceitos não são iguais, porém não deram justificativas corretas. Dois (G4 e G8) disseram que a diferença estaria no fato que eles atingem dimensões diferentes, ao associar o Turismo Sustentável mais com a dimensão ambiental, e o Turismo Responsável mais com as dimensões social e/ou econômica (G4: "É porque o Turismo Responsável acho que é mais no sentido social, e o Turismo Sustentável ele é mais abrangente, eu acho. Acho que ele é o social e também em relação ao meio ambiente"; G8: "Acho que o Turismo Sustentável é mais relacionado ao meio ambiente, já o Turismo Responsável está ligado também à economia e social"). E os outros dois (G9 e G10), afirmaram que o Turismo Responsável seria mais amplo que o Turismo Sustentável, por acreditarem que este não atinge a dimensão social, o que faz referência a grande marca que esse conceito deixou por ter sido criado primeiramente preocupado somente com os aspectos causados pelos impactos ambientais.

Quanto ao objetivo principal dessa pergunta, tivemos algumas falas (G1, G7, G9 e G10) que caminharam para corroborar com a percepção a qual buscávamos comprovar - que o Turismo Sustentável é apreendido como um conceito mais distante da prática se comparado à ideia que o termo Turismo Responsável consegue transmitir. Sobre esse assunto citaremos os trechos que se mostraram mais interessantes:

G1: O conceito de sustentabilidade é um conceito que já existe há algum tempo, que caiu até numa visão um pouco negativa com sua utilização, talvez porque ele não transmitia algo concreto ou algo factível ou que as pessoas pudessem compreender exatamente qual é o seu papel.

G7: o que eu entendi de diferença entre Turismo Responsável e Sustentável, é que Turismo Sustentável ficou sendo um conceito de "utopia útil", e Turismo Responsável seria algo mais factível, mais viável do ponto de vista de conceito - que são medidas responsáveis dentro da cadeia produtiva do turismo. A sustentabilidade mesmo sendo uma "utopia útil", ela tem uma série de frentes de responsabilidades que precisam ser feitas. [...] Eu tendo a achar que Turismo Responsável seria uma soma de iniciativas, de políticas, de frentes, ações, atuações, responsáveis para o turismo, em seus vários stakeholders [...].

G9: A sustentabilidade não é um conceito muito bem definido no Brasil, parece coisa de acadêmico, parece assim que toda vez que fala parece uma coisa muito distante, pela forma que foi colocada. Porque parece que a sustentabilidade já existe e que a gente fica querendo implementar alguma coisa que já tem, enquanto na verdade não é isso.

G10: Se confunde, se funde, a responsabilidade você vai ter que ter pra qualquer atividade que você vá desenvolver e talvez seja muito mais adequado a gente falar Turismo Responsável, é mais fácil, fica mais palpável, não fica tão filosófico como é o Turismo Sustentável. Porque quando você fala Turismo Sustentável fica tão filosófico, e quando é responsável [...] consigo tangibilizar 
isso de uma maneira mais lógica, mais "entendível" pra sociedade do que o sustentável. [...] o sustentável é mais simpático [...], porque a sociedade já disseminou isso, mas se perguntar para as pessoas o que é sustentável elas não conseguem muitas vezes definir, segue mais pra sustentabilidade ambiental, ao invés de se tratar o amplo, e às vezes também vai para o lado da sustentação da atividade e aí tem todas as polêmicas do conceito da sustentabilidade.

Além da percepção de que o termo Turismo Responsável é mais fácil de ser visualizado na prática, queríamos perceber nas falas se havia algum conhecimento sobre a ligação tão forte do TR com a "chamada" à ação de todos. Sobre essa informação, somente um entrevistado (G7) comentou algo correlacionado ao afirmar a seguinte frase: "Eu tendo a achar que Turismo Responsável seria uma soma de iniciativas, de políticas, de frentes, ações, atuações, responsáveis para o turismo, em seus vários stakeholders".

Visto isso, é perceptível que as respostas às perguntas 2 e 3 mostraram que, embora algumas pessoas possuam uma boa percepção do conceito, elas possuem apenas uma noção ou nunca ouviram falar sobre Turismo Responsável. E apesar de haver uma fronteira não tão distante entre os conceitos de Turismo Sustentável e Turismo Responsável, não há uma maciça percepção quanto a diferença entre eles. Diferença essa que foi exposta nesse trabalho. Dessa forma, vale destacar a necessidade de se fazer um seminário para se discutir o conceito de Turismo Responsável e os seus princípios como parte de um programa de formação sobre o tema para que ele, assim, passe a ser apropriado pelos gestores com clareza.

A percepção da relevância do TR para a gestão pública do turismo foi avaliada pela quarta pergunta: Na sua opinião, qual a importância da discussão sobre Turismo Responsável no MTur? Essa pergunta foi fundamental para a presente pesquisa, pois suas respostas mostraram que a importância que o tema tem alcançado mundialmente já é percebida e incorporada por todos os gestores do órgão que participaram da pesquisa de campo. Ademais, ao se analisar essas respostas ficou claro que a maioria dos entrevistados (G1, G2, G7, G8, G9 e G10) já percebeu que o tema necessita ser um pilar ou uma diretriz transversal a todas as iniciativas do MTur, Como fica evidente nas seguintes afirmações:

G1: Eu acredito que qualquer tema que tenha preocupações com o uso racional dos nossos recursos, para fins da atividade turística, deve ser envolvido no desenho das nossas políticas [...]. Eu acredito que deva ser um conceito transversal que deva reger todas as nossas ações. 
G2: Eu acho super importante. Eu acho que ele tem que estar na base de todo esse nosso olhar para o turismo [...]. Para mim ele é a base do planejamento. G7: Sem dúvida. O tema de responsabilidade e sustentabilidade eu acho que não seja nem mais possível de deixar de fora. Os gestores podem insistir, podem tentar priorizar outras questões, mas o mundo cobra por isso [...]. Faz parte da atuação do Ministério propor políticas e intervir nos territórios, nos destinos, para que eles sejam sustentáveis [...]. Eu acho que esse tema deve nortear a política do Ministério do Turismo [...].

G10: É relevante e o Ministério sempre trabalhou, apesar de não ser com essa expressão [...]. Eu não imagino que esse tema deve ser foco de um programa, mas concordo com a política do Ministério de se trabalhar isso transversalmente em todos os programas.

Após a verificação sobre a percepção do tema e de sua inserção no órgão, partiu-se para checar quais seriam as ações do MTur que, na visão dos entrevistados, estariam relacionadas com o Turismo Responsável. Assim, a quinta pergunta foi a seguinte: Quais são os programas ou as políticas públicas do MTur relacionadas com o Turismo Responsável? Com ela, pretendia-se verificar se as iniciativas que foram selecionadas nessa pesquisa como sendo responsáveis seriam também percebidas pelos entrevistados sob essa ótica. Ao mesmo tempo, conferir se alguma iniciativa, em curso, diferente das que selecionamos seria citada, para assim avaliarmos e, caso coubesse nos critérios dessa pesquisa, acrescentaríamos à análise feita no capítulo anterior.

Pelos resultados observou-se que a grande maioria das iniciativas selecionadas (seis) foi citada pelo menos por um entrevistado. A única que não foi citada nenhuma vez foi o Programa de Regionalização do Turismo (PRT), fato interessante, visto que em nossa análise anterior esse programa mostrou-se um dos mais completos, pois das sete iniciativas selecionadas e avaliadas no Capítulo 6 o PRT é um dos três únicos programas que atingem as três dimensões da responsabilidade, junto com o TBC e com o Programa Talentos do Brasil Rural. Todavia, esse resultado não é uma surpresa, uma vez que quando verificamos o conhecimento dos entrevistados sobre o tema nenhum citou como características do TR qualquer conteúdo que se relacionasse com os principais atributos do PRT, como o princípio da África do Sul (2002) que diz respeito ao aumento da integração dos atores da cadeia produtiva da área, ou o objetivo de aumentar a integração dos atores econômicos locais para reduzir as fugas de capitais (ÁFRICA DO SUL, 2002; GÂMBIA, 2002); ou até mesmo o objetivo da África do Sul (2002) de envolver a comunidade local no planejamento e na tomada de decisão dos assuntos relacionados ao turismo. 
A iniciativa mais citada foi o Programa Turismo Sustentável e Infância, que foi mencionada quatro vezes (G1, G3, G9 e G10), talvez por possuir em seu próprio nome a palavra "sustentável", e esse conceito ser quase sempre associado diretamente ao TR. O Turismo Acessível e o Passaporte Verde foram citados cada um por duas vezes. Já o Turismo de Base Comunitária, o Viaja Mais - Melhor Idade e o Talentos do Brasil Rural foram lembrados por uma única pessoa (G10). Com esses resultados, foi possível notar que os próprios gestores do MTur não possuem um conhecimento aprofundado sobre a prática da responsabilidade pelo órgão que atuam ou representam; ou até mesmo não conhecem todas as ações do MTur.

Algumas ações distintas das que foram analisadas nesse trabalho foram mencionadas. Todavia, após verificação do alcance do objeto dessa pesquisa, elas não foram incluídas, já que não apresentaram ações significativas no momento do desenvolvimento da pesquisa e o nosso objetivo só alcançava iniciativas atuais. Elas foram: alguns segmentos como o LGBT, Ecoturismo, Turismo de Aventura e Turismo Cultural.

Importante dizer que um dos entrevistados (G1), apesar de ressaltar somente dois programas, acrescenta um comentário que reforça a ideia que tratamos na pergunta anterior, a de que o TR trata-se de um tema transversal que deve ser levado a todas as áreas do MTur, como pode ser vista em sua fala exposta abaixo:

G1: por ser um tema transversal, acredito que a gente deveria levar esse tipo de critério ou de conceito às demais políticas do Ministério para que se torne um tema transversal aqui dentro, porque quando a gente for ver, algumas ações específicas, até infraestrutura pode ter um impacto muito maior, enfim, e também pra atividade turística como um todo. Então, esse tipo de conceito também deve ser levado a essas áreas por mais técnicas e específicas que sejam.

Depois de verificarmos quais as iniciativas seriam percebidas como ações responsáveis, partimos para a percepção das dificuldades para se inserir o tema Turismo Responsável na agenda da pasta. A última pergunta foi se os gestores saberiam dizer: Quais são os entraves ou as dificuldades que podem existir para a implantação do Turismo Responsável?

De maneira geral, o tema demonstra ter sido bem recebido por todas as áreas. Por exemplo, como enfatiza o G1: "esse tema é uma agenda muito positiva que eu vejo que os governos, as figuras políticas não têm dificuldade em querer trabalhar". Porém, apareceram algumas falas que destacaram dificuldades que poderiam ocorrer, como: o 
próprio desconhecimento sobre o assunto em todos os níveis; as dificuldades intrínsecas ao local que estão fora do alcance do MTur, mas que influenciam diretamente o turismo; a resistência dos empresários por associarem muitas vezes essas ações a custos para seus empreendimentos; e a própria falta de consciência ambiental ou até mesmo a falta de educação dos turistas.

Por fim, ao se fazer uma análise baseada em todas as entrevistas, a pesquisa de campo mostrou que, apesar de todas as pessoas chave entrevistadas terem apenas uma noção do que seria o Turismo Responsável, o conceito de responsabilidade possivelmente ligados à responsabilidade social e ambiental das empresas - é conhecido e desejado.

Em muitas entrevistas a necessidade de mudança e a percepção de que a responsabilidade no turismo é a melhor maneira de se desenvolver o turismo têm sido como um "guarda-chuva" em muitos discursos. Percebe-se, também, que apesar de não ser conhecido com esse nome, há várias políticas públicas no Brasil que são percebidas pelos gestores como correlacionadas ao TR, por terem objetivos que envolvem a sustentabilidade ou a própria responsabilidade, e confirmam a conclusão do capítulo anterior que o MTur possui iniciativas responsáveis.

A inserção do Turismo Responsável como uma política do Ministério do Turismo poderia ser um importante passo no caminho para a inclusão da sociedade civil e da localidade na concepção e, assim, no aumento dos resultados positivos das políticas de turismo. Todavia, ficou claro com essa análise, que antes de qualquer atitude nesse sentido, seria aconselhável executarem uma discussão interna do conceito, para a sua disseminação e seu esclarecimento. 
Q menos que modifiquemos a nossa maneira de pensar, não seremos capazes de resolver as problemas causados pela forma como nos acostumamos a ver o mundo.

Qlbert Einstein 
Essa dissertação surgiu da necessidade de se construir conhecimento científico para responder a indagações originadas da relação recíproca entre teoria e prática, ou seja, nasceu da junção de elementos da pesquisadora-acadêmica conhecimentos adquiridos em sua graduação e pós-graduação - com fatores da pesquisadora-profissional - experiência e observação como servidora do Ministério do Turismo.

Portanto, para a finalização desse trabalho, será constatado o cumprimento das razões de se ter realizado essa pesquisa. Para tanto, far-se-á, primeiramente, um resgate dos objetivos desse estudo, das indagações propulsoras e da questão de pesquisa, junto com a comprovação de seu cumprimento, de forma a possibilitar a corroboração ou o refutamento da hipótese de pesquisa.

Posteriormente, é importante expor as limitações dessa pesquisa, as facilidades que contribuíram para um melhor desempenho da pesquisadora, bem como as dificuldades encontradas.

Por fim, serão apresentadas algumas considerações e contribuições sobre o tema estudado, recomendações para a potencialização do desenvolvimento do Turismo Responsável no Brasil, além de sugestões para pesquisas futuras.

\section{Razões da pesquisa e seu cumprimento}

O Objetivo Geral dessa pesquisa foi "Analisar as iniciativas em curso no Ministério do Turismo sob a ótica do Turismo Responsável (TR)", com a finalidade de identificar se há, atualmente, no Brasil, políticas que possuam o seu pilar na responsabilidade, isto é, iniciativas/ações geridas pelo Ministério do Turismo que sejam voltadas para uma política de Turismo Responsável. Para o alcance desse objetivo geral, delineamos a obtenção de quatro objetivos específicos.

O primeiro objetivo específico buscou a reflexão da responsabilidade, com o seu enquadramento sob o enfoque do Turismo. Esse objetivo foi abordado no segundo e no terceiro capítulos dessa dissertação. Sua consecução iniciou-se com as reflexões sobre a origem e os significados da responsabilidade, assunto tratado no Capítulo 2. Nesse contexto, foi possível verificar que de forma geral um sujeito responsável pode ser entendido como uma pessoa que se compromete a fazer a sua parte. Também foi explicado, que o primeiro significado do termo na modernidade foi político, com 
indicativas do caráter do governo constitucional que age sob o controle dos cidadãos e em função desse controle (ABBAGNANO, 2012). Discorreu-se, ainda, sobre o conceito de responsabilidade defendido por Kant (2005), que relaciona a responsabilidade com a condição da liberdade. Foi mostrado, também, que ela pode ter dois significados distintos, porém interdependentes - um ligado aos estímulos criados pelas consequências da ação ou da omissão de uma pessoa; e outro relacionado à capacidade de resposta a situações que surgem no dia-dia (ALEXANDER; GOODWIN; ROBINSON ${ }^{117}$ ).

Nessa busca pelos conceitos e significados da responsabilidade surgiram desdobramentos, como a discussão da aplicação da responsabilidade nas organizações. Nesse assunto, vale destacar que foram expostos os motivos pelos quais as organizações podem adotar atitudes responsáveis, que giram em torno de motivos de interesse econômico, ou mais relacionados à ética, quando o agir de forma responsável está associado aos valores e princípios do próprio gestor, isto é, à sua personalidade ou ao seu estilo de vida.

Como esse primeiro objetivo específico envolvia o enquadramento da responsabilidade sob o enfoque do turismo, perpassou-se, no terceiro capítulo, pelo contexto de sua apropriação pelo turismo, o qual evidenciou os motivos que causaram a emergência de uma outra forma de se desenvolver o turismo e o início do se pensar o turismo com ética e responsabilidade. Dessa maneira, verificou-se que o prémovimento das políticas de TR foi resultado da preocupação mundial com a sustentabilidade e de seus diversos eventos e ações somados à percepção dos impactos negativos do turismo e à mudança do perfil do turista moderno. Por fim, esse objetivo foi alcançado ao discutir os conceitos de Turismo Responsável, a origem de seu movimento e sua evolução. Portanto, a construção de referenciais teóricos que subsidiaram o desenvolvimento de toda a pesquisa foram os passos dados para 0 alcance do primeiro objetivo.

O segundo objetivo específico visou à construção de um histórico das políticas públicas do Ministério do Turismo sob o olhar do TR. Para isso, em primeiro lugar, foi preciso o desenvolvimento, no Capítulo 4, dos fundamentos teóricos na temática de políticas públicas e da importância destas para o desenvolvimento do turismo. Para então se chegar à conclusão do objetivo propriamente dito, o qual se demonstrou

\footnotetext{
${ }^{117}$ Disponível em http://www.responsibility.org.uk/. Acesso em 12 de maio de 2014.
} 
essencial para o entendimento do contexto atual da gestão pública brasileira do turismo, que passou de um enfoque exclusivamente econômico para tentativas do uso do aproveitamento do turismo como ferramenta de inclusão social e de alívio da pobreza.

Todos esses estágios fizeram-se essenciais para a compreensão do objeto de estudo e para a realização de todo o processo de construção desse trabalho, especialmente de sua terceira etapa - a análise dos dados, que teve início com a concretização do terceiro objetivo específico: "Verificar os parâmetros utilizados pelas políticas públicas de Turismo Responsável adotados na África do Sul e em Gâmbia".

Para se alcançar esse objetivo, realizou-se no Capítulo 5 a primeira análise desse estudo. Com isso, as políticas públicas da África do Sul e de Gâmbia foram examinadas e delas extraíram-se dimensões da responsibilidade, além de princípios, premissas e objetivos do Turismo Responsável. Verificou-se, também, que ambos os países basearam-se na Declaração da Cidade do Cabo (2002) para a construção de sua política pública de Turismo Responsável, fato este que estimulou o uso de tal declaração como base também na análise das iniciativas do Brasil. Essas informações foram essenciais para o alcance do quarto e último objetivo específico, que era a identificação de quais iniciativas do MTur seriam voltadas para o fomento da responsabilidade no turismo.

Esse último objetivo foi tema do sexto capítulo, no qual se evidenciou a descoberta de sete iniciativas responsáveis do MTur, entre elas, um programa de sensibilização para o combate à exploração de crianças e adolescentes no turismo (TSI); o desenvolvimento de ações relacionadas à valorização da cultura da comunidade local e a diversificação de produtos turísticos que ajudam a preservar as tradições locais (TBC e Talentos do Brasil Rural); um programa de incentivo à inclusão da terceira idade na atividade turística (Viaja Mais - Melhor Idade) e diversas ações voltadas para a promoção da acessibilidade de pessoas com deficiência ou mobilidade reduzida no turismo (Turismo Acessível); e, ainda, a participação em uma campanha mundial (Passaporte Verde) que visa incentivar o turista a consumir de forma consciente e reduzir os impactos do turismo no meio ambiente e na comunidade.

Além disso, verificou-se que a forma descentralizada que o MTur executa sua gestão, que resulta no Programa de Regionalização do Turismo (PRT), pode ser considerada a iniciativa mais importante do órgão ao se pensar em TR, uma vez que 
sua essência está na participação de todos os stakeholders na gestão do turismo, como também, na adoção de premissas como a abordagem territorial, a integração e participação social, a inclusão e a sustentabilidade. Pontos que conversam perfeitamente com os princípios do TR que foram tratados nesse trabalho.

Tudo isso revelou que o órgão busca sim fomentar a responsabilidade na gestão do turismo e o faz por meio do desenvolvimento de iniciativas responsáveis, apesar de não usar a denominação explícita do termo "responsável".

Na segunda parte do Capítulo 6, foi feita a segunda análise dessa investigação - a avaliação de tais ações. De forma a concluir que o MTur desenvolve três iniciativas que abrangem as três dimensões da responsabilidade - econômica, social e ambiental (Turismo de Base Local, PRT e Talentos do Brasil Rural); duas que abarcam as dimensões econômica e social (Turismo Acessível, Viaja Mais - Melhor Idade); uma que envolve as dimensões social e ambiental (Passaporte Verde); e uma que abarca somente a social (TSI). E, ainda, foi possível perceber, entre outras observações, que a responsabilidade social é a única dimensão atingida por todas as iniciativas.

Com isso, a primeira e segunda pergunta propulsora da pesquisa foram respondidas, que eram as seguintes: "Apesar de não existir um Plano Nacional de Turismo Responsável no Brasil, as políticas públicas federais do País estão de alguma maneira contemplando a fomentação e o desenvolvimento responsável do turismo?" e "Caso positivo, como isso é feito?".

Ao se analisar o contexto atual do Brasil, com a apreciação do PNT em execução (2013-2016), respondeu-se ao terceiro questionamento propulsor: "O atual Plano Nacional de Turismo possui alguma preocupação com o desenvolvimento responsável do turismo mesmo que não utilizando o termo Turismo Responsável?". Essa pergunta teve resposta positiva ao verificar que este Plano possui pontos relacionados com a preocupação com a responsabilidade, tais como as suas diretrizes: i) Geração de oportunidades de emprego e empreendedorismo; ii) Participação e diálogo com a sociedade; iii) Incentivo à inovação e ao conhecimento; e iiii) Regionalização. E possui como uma de suas ações o estímulo ao desenvolvimento sustentável da atividade turística, que envolve o combate à exploração de crianças e adolescentes na cadeia produtiva do turismo, a integração da produção associada na cadeia produtiva do turismo e o fomento ao turismo de base comunitária. 
Como já foi dito, o cumprimento desses quatro objetivos específicos possibilitou a realização do objetivo geral dessa pesquisa, que foi concretizado na segunda parte do Capítulo 6, com a análise das iniciativas responsáveis do MTur. Essa investigação permitiu, também, fornecer as respostas à questão de pesquisa: "as atuais políticas públicas do MTur contemplam de alguma forma o Turismo Responsável nos seus diversos campos - ambiental, social, cultural e econômico?".

No sétimo e último capítulo desse estudo, como forma de enriquecimento da pesquisa, realizou-se a terceira análise desse estudo, a análise dos dados coletados na pesquisa de campo - entrevistas semiestruturadas junto a dez gestores do MTur. A justificativa desta configurou-se no pressuposto de que para um tema ser incorporado a uma política ele demanda previamente o seu entendimento e o reconhecimento de sua importância. Dessa maneira, fez-se interessante a investigação da visão de gestores do MTur sobre a temática.

A partir dos pressupostos teóricos construídos nos capítulos anteriores e, também, da exploração das falas dos gestores entrevistados, foi possível responder à última pergunta propulsora do estudo: "Como a responsabilidade e o Turismo Responsável são entendidos e percebidos pelos gestores públicos do Ministério do Turismo do Brasil (MTur)?". Com essa avaliação foi possível concluir que, dentro do alcance dessa pesquisa, o conceito de responsabilidade é desejado e percebido de maneira positiva por todos os entrevistados, apesar dessas pessoas possuírem somente uma noção do que seria o Turismo Responsável e o perceber, frequentemente, associado ao conceito de responsabilidade social e ambiental das empresas, ou como sendo sinônimo de Turismo Sustentável.

Em vista dos fatos mencionados, consegue-se ter subsídios para afirmar a corroboração da hipótese de pesquisa, a qual foi "Sendo o Ministério do Turismo o órgão responsável pela gestão pública federal do turismo no Brasil e se o Turismo Responsável é um pilar fundamental da gestão contemporânea do turismo no mundo, então o MTur está incorporando de alguma maneira o Turismo Responsável no delineamento de sua gestão". Essa hipótese é automaticamente confirmada com todos os dados que foram mostrados durante esse estudo, em especial ao se evidenciar a essencialidade do TR quando se pensa em gestão do turismo na atualidade, e ao demonstrar que o MTur possui iniciativas responsáveis, o que comprova que suas 
preocupações parecem caminhar na direção das inquietações e dos cuidados presentes atualmente no mundo para o campo do turismo.

\section{Limitações, facilidades e dificuldades}

Ressalta-se que toda essa pesquisa foi realizada dentro das limitações impostas pelo escopo desse trabalho, isto é, a análise desenvolvida limitou-se aos dados extraídos somente da análise das políticas públicas da África do Sul e de Gâmbia, somada à Declaração da Cidade do Cabo; e a visão dos dez gestores públicos do MTur investigados na Pesquisa de Campo. Portanto, essa dissertação teve como base a análise dos documentos citados somada às observações extraídas das dez entrevistas, o que não exclui a existência e a importância de outras políticas públicas de TR, assim como, o fato de não investigar a opinião de todos os gestores do órgão não elimina a seriedade da provável existência de outros pensamentos no órgão.

Por outro lado, destaca-se que, como a pesquisadora é servidora do MTur, alguns aspectos facilitadores devem ser enfatizados, pois estes foram decisivos na consecução desse estudo. O primeiro deles refere-se ao amplo acesso aos documentos internos do órgão - o que envolve acesso a resumos, apresentações de coordenadores e outros documentos internos que ajudaram na solidificação da pesquisa -; contato com os gestores públicos do órgão, o que facilitou o acesso a eles para a realização das entrevistas; e, ainda, a possibilidade de uma visão mais próxima da realidade do órgao, com grande entendimento de sua estrutura e funcionamento, bem como conhecimento prévio sobre seus programas e suas iniciativas - o que contribuiu substancialmente para a identificação das iniciativas responsáveis e para uma melhor percepção de seus resultados.

Porém, o fato da pesquisadora pertencer ao quadro de funcionários do MTur não impediu o aparecimento da dificuldade em se aplicar as entrevistas no alto escalão do MTur, pois apesar de existirem relacionamentos e contatos construídos durante o exercício profissional da pesquisadora, no momento da aplicação das entrevistas houve uma mudança na estrutura do órgão com a saída do então Ministro do Turismo.

No entanto, é válido evidenciar que apesar das limitações e das dificuldades que surgiram, a pesquisa foi realizada com sucesso, pois atingiu todos os seus objetivos e respondeu a todos os seus questionamentos, além de ter proporcionado 
discussão e contribuições à temática, matérias que serão apresentadas no tópico a seguir.

\section{Considerações, recomendações e contribuições}

Em virtude do que foi mencionado e da perspectiva traçada com os resultados dessa pesquisa, somos levados a acreditar que a administração pública federal demonstra intenções de desenvolver o turismo com responsabilidade. No entanto, para que se consiga isso de fato é preciso considerar que ela possui diversos desafios a serem enfrentados. O primeiro deles seria o entendimento correto do conceito de TR pelos próprios membros do MTur, para sua completa absorção e aplicação. Em seguida seria conseguir que esse conceito entrasse na agenda da pasta de forma estrutural, incorporando-o como uma diretriz ou um pilar central para o desenvolvimento de todas as ações do Ministério.

Após a ultrapassagem desses desafios, teria que vir a complexa busca pelo equilíbrio entre o apelo inegavelmente existente do interesse exclusivo nos resultados econômicos do desenvolvimento da atividade e a ética necessária ao se desenvolver o turismo em prol do ser humano, com o reconhecimento de que o turismo não é uma panaceia, pois não é sempre que ele deve ser estimulado. Desafio este que vai ao encontro do princípio orientador do TR indicado na Declaração da Cidade do Cabo (2002) e reforça sua importância: "Avaliar os impactos econômicos antes de desenvolver o turismo e dar preferência para as formas de desenvolvimento que beneficiem as comunidades locais e minimizem os impactos negativos sobre os meios de vida locais (por exemplo, por meio da proibição de acesso a recursos), reconhecendo que o turismo não pode ser sempre a forma mais adequada de desenvolvimento econômico local".

Esses seriam os passos anteriores à execução de uma política de Turismo Responsável, contudo haveria, também, desafios para se conseguir alcançar, sensibilizar e fomentar as localidades e todos os envolvidos na cadeia produtiva do turismo para responderem e cumprirem seu papel para o desenvolvimento da responsabilidade do turismo, visto que a participação de todos e as ações locais são pontos-chave do TR. 
Para tanto, recomenda-se, primeiramente, a realização de seminários, debates e workshops internos sobre a temática, com o intuito da disseminação de conhecimento do tema, para a sua compreensão, percepção de sua essencialidade e, então, sua internalização. Além disso, sugere-se a observação do desenvolvimento e dos resultados dos países que já adotaram uma Política Nacional de Turismo Responsável para o estímulo à adoção do conceito como estratégia fundamental.

Alerta-se, também, que para se evitar o fomento da irresponsabilidade deverá haver sempre um estudo de viabilidade que envolva as três dimensões da responsabilidade antes do estímulo ao desenvolvimento do turismo por parte do Governo, e, ainda, a existência da preocupação com a qualidade do turismo que se almeja desenvolver e o tipo de turista que se visa atingir, em contrapartida com a preocupação em se atingir grandes quantitativos nos resultados econômicos e no número de chegadas de turistas. Quanto a esta última observação levantada, é importante lembrar que nem sempre crescimento econômico significa desenvolvimento com reais benefícios para a sociedade.

É válido reforçar que o papel do Governo Federal no desenvolvimento do TR envolve o desenho de diretrizes e metas para nortearem o restante do país, como também a implantação de ações para promover a responsabilidade, e, ainda, a sensibilização da cadeia produtiva do turismo, além do estímulo a projetos que tenham a responsabilidade em suas três dimensões como pilar e, assim, causem reais impactos positivos na localidade.

Já que o MTur e o Governo Brasileiro de forma geral esperam que o turismo nacional responda "com crescimento sustentado e sustentável, redução de desigualdades regionais, inclusão social e geração de emprego e renda", e ainda que o PNT contribua para o "desenvolvimento econômico, social e a erradicação da pobreza" (BRASIL, 2013), a visão do Turismo Responsável como estratégia de planejamento do órgão é recomendada, uma vez que, como evidenciado no Capítulo 3 dessa pesquisa, o Turismo Responsável é uma alternativa viável na busca de resultados positivos para essas questões, e deve ser aplicado a qualquer segmento ou tipo de turismo, e sua coerência está na adoção de sua prática como estratégia, e não apenas em iniciativas pontuais, como de fato acontece no órgão. Ou seja, para que o MTur consiga atingir no turismo os resultados que se propõe a alcançar, pode-se dizer que ele teria mais chances de sucesso se o TR tornasse um eixo estratégico de planejamento da gestão 
do turismo capaz de abarcar essas iniciativas e fomentar outras no mesmo sentido. Não se deve, portanto, desvincular o crescimento econômico do turismo do desenvolvimento humano e social, pois isso seria enxergar ou tratar o turismo como um fim em si. Como também, não se deve separar as três dimensões da responsabilidade, uma vez que elas estão relacionadas entre si e o ideal é sempre abarcá-las conjuntamente.

Ademais, um importante ponto que foi destacado durante esse trabalho e merece ser relembrado é a questão que o Turismo Responsável busca o desenvolvimento de "melhores lugares para se viver, melhores lugares para se visitar", o que deixa subentendido que o desenvolvimento dos municípios deve ser pensado em primeiro lugar para o benefício de seus moradores. Pois um local que proporciona qualidade de vida a estes, consequentemente, é também um bom local para ser visitado. Ao se desenvolver e proporcionar um lugar ideal para os moradores, esse próprio fator pode proporcionar a oferta de um turismo melhor, uma vez que não há separação entre infraestrutura e serviços locais de moradores ou de turistas. Estes ao chegarem ao destino turístico usufruirão também do que é proporcionado aos residentes locais, como transporte público e serviços de saúde.

Dessa forma, é imprescindível que todos se conscientizem de que o turismo positivo e de qualidade acontece quando os cidadãos locais possuem serviços básicos de qualidade e vivem em um bom lugar. Enfatiza-se isso com o propósito de lembrar que como o Brasil é um país ainda em desenvolvimento e luta para proporcionar o mínimo de infraestrutura básica aos moradores ainda em muitas de suas localidades, a proposta de metas como "transformar o Brasil no terceiro maior PIB turístico do mundo até 2022" (BRASIL, 2013, p.03) pode demonstrar incoerência ou irresponsabilidade, já que para que ela seja atingida exigir-se-á um "crescimento anual médio de mais de $8 \%$ no turismo do Brasil, taxa superior ao crescimento médio dessa atividade no mundo e ao próprio crescimento do nosso PIB" (BRASIL, 2013, p.03); além do MTur depender de ações que envolvem pastas que não são de sua alçada. Recomenda-se, então, cautela ao se propor metas e resultados para o turismo, sempre com a necessidade do pensamento da responsabilidade em primeiro lugar para que o Brasil "use o turismo a seu favor, e não seja usado por ele" (GOODWIN, 2014). Fato este que não diminui sua importância e sua contribuição para o desenvolvimento do país. 
Tendo em vista o que foi mencionado, acredita-se que essa pesquisa além de contribuir com a construção sólida de material, escrito em língua portuguesa, sobre a temática do TR, assim como evidenciar que o MTur já demonstra interesse no tema ao se identificar sete programas do órgão com o víes da responsabilidade - ; a partir do desenvolvimento de suas análises, fornece, ainda, material que pode servir de subsídio para o desenvolvimento de outras pesquisas acadêmicas, de políticas públicas de turismo, ou até mesmo, de estímulo à adoção do TR como diretriz da Política Nacional de Turismo no Brasil. Por todos esses aspectos, entendemos que esse trabalho atinge suas expectativas tanto no aspecto acadêmico quanto no profissional.

Neste sentido, com as informações levantadas nessa investigação, pretende-se elaborar artigos científicos para divulgação do conceito de TR no país, bem como usála como base para promoção da importância de sua adoção na gestão pública federal e em todos os casos quando se pensa em planejamento do turismo, independentemente do nível (regional, estadual, municipal ou local) ou da forma da instituição (pública ou privada). Além disso, almeja-se evidenciar a importância da participação de todos na construção do TR, inclusive dos próprios turistas.

Por fim, entende-se que a presente dissertação deixa a inspiração para 0 estabelecimento de outras/novas formas de abordagem do tema que aqui não foram o foco. Dessa maneira, no próximo tópico, são exibidos alguns pontos que podem ser trabalhados em pesquisas posteriores.

\section{Sugestões para pesquisas futuras}

- Estudar o Turismo Responsável com foco nos resultados da adoção desse termo em políticas públicas internacionais, com intuito de se evidenciar os resultados alcançados pelos países que adotaram uma Política Nacional de TR.

- Analisar outras políticas públicas de TR, com enfoque comparativo entre teoria e prática.

- Pesquisar como os resultados do MTur são monitorados, com intuito de avaliação dos resultados das iniciativas responsáveis do órgão.

- Examinar o Turismo Responsável sob a ótica dos turistas ou das empresas da cadeia produtiva do turismo. 


\section{REFERÊNCIAS}


ABBAGNANO, N. Dicionário de Filosofia. São Paulo, SP: WMF MARTINS FONTES, 2012.

ÁFRICA DO SUL. The Development and Promotion of Tourism in South Africa. 1996.

ÁFRICA DO SUL. White Paper on the Development and Promotion of Tourism in South Africa. Ministry for Finance, Business Promotion and Turism. 2001.

ÁFRICA DO SUL. National Responsible Tourism Development Guidelines for South Africa. 2002.

ÁFRICA DO SUL. Responsible Tourism in Cape Town. Cidade do Cabo, 2007.

AGUIAR, L. B. Estado, Turismo, Cultura e Desenvolvimento: organização empresarial e a construção do consenso sobre a importância do turismo para o Brasil (1966-1988). In: Anais do VI Simpósio Nacional Estado e Poder: Cultura na UFS. Rio de Janeiro, RJ: Universidade Federal Fluminense, 2010. Disponível em: <www.historia.uff.br/estadoepoder/6snepc/GT1/GT1-LEILA.pdf>. Acesso em: $10 \mathrm{abr}$. 2014.

ALEXANDER, GOODWIN e ROBINSON. Disponível em: <http://www.respon sibility.org.uk/>. Acesso em: 12 mai. 2014.

ANGELI, M. B. Planejamento e Organização do Turismo. 9a ed. Campinas, SP: Papirus, 2003.

ANSARAH, M. G. R. Turismo - Segmentação de Mercado. São Paulo, SP: Ed. Futura, 2001.

ARANHA, M.; MARTINS, M. Temas de filosofia. 3. ${ }^{a}$ ed. rev. São Paulo, SP: Moderna, 2007.

ARAÚJO, L. M. de. Participação sociopolítica no planejamento turístico. In: Turismo - Visão e Ação. Vol. 8 - n.1 - jan./abr. Itajaí: Univali, 2006. p. 153-164.

ARAÚJO, C. M.; TASCHNER, G. Turismo e políticas públicas no Brasil. In: BENI, Mario Carlos (org.). Turismo, planejamento estratégico e capacidade de gestão desenvolvimento regional, rede de produção e clusters. Barueri, SP: Manole, 2012. (p.69-86).

ASHLEY, A. P. Ética e Responsabilidade Social nos Negócios. 2ª ed. São Paulo, SP: Saraiva, 2005.

AURÉLIO, B. H. F. Novo Dicionário Aurélio da Língua Portuguesa. Curitiba, PR: Ed. Positivo, 2009.

BARDIN, L. Análise de conteúdo. Lisboa: Edições 70, 1997. 
BARBIERE, J. C.; CAJAZEIRA J. E. R. Responsabilidade Social Empresarial e Empresa Sustentável: da teoria à prática. São Paulo: Saraiva, 2009.

BARRETTO, M.; BURGOS, R.; FRENKEL, D. Turismo, políticas públicas e relações internacionais. Campinas, SP: Papirus, 2003. (Coleção Turismo)

BARROS, A.; DUARTE, J. (Orgs.). Métodos e Técnicas de Pesquisa em Comunicação. São Paulo, SP: Ed. Atlas, 2008.

BASSO, K. G. F. Políticas Públicas do Turismo em Áreas Naturais e Evolução do Conceito de Ecoturismo no Brasil. In: Anais do II Encontro Interdisciplinar de Ecoturismo em Unidades de Conservação (EcoUC). Itatiaia: Instituto Physis Cultura e Ambiente, 2007. Disponível em <www.physis.org.br/ecouc/Artigos/Artigo51.pdf>. Acesso em: 10 set. 2013.

BASSO, K. G. F. Proposta de Programa de Turismo Responsável. Brasília, DF, 2013.

BECKER, B. K. Políticas e Planejamento do Turismo no Brasil. In: YÁZIGI, E.; CARLOS, A. F.; CRUZ, R. C. Turismo: espaço, paisagem e cultura. São Paulo: Hucitec, 1996. p. 181-192.

BENI, M. C. Análise Estrutural do Turismo. São Paulo, SP: Editora Senac, 2003.

BENI, M. C. Política e Planejamento de Turismo no Brasil. São Paulo, SP: Ed. Aleph, 2006.

BENI, M. C. Como certificar o turismo sustentável? In: Espaço Acadêmico. Disponível em: <www.espacoacademico.com.br/037/37ebeni.htm>. Acesso em abril de 2014.

BORGES, C. A. Sustentabilidade: Utilização indiscriminada nas políticas do turismo brasileiro. Dissertação (Mestrado em Geografia) - Universidade de Brasília. Brasília, DF, 2013.

BRASIL. Embratur. Política Nacional de Turismo: abril/86. Rio de Janeiro: Embratur, 1986.

BRASIL. Embratur. Embratur 40 Anos: uma trajetória do turismo no Brasil. Brasília: MTur, 2006.

BRASIL. Ministério da Indústria, do Comércio e do Turismo; Embratur. Política Nacional de Turismo: diretrizes e programas. 1996 - 1999. Brasília: Embratur, 1996.

BRASIL. Ministério do Turismo. Plano Nacional de Turismo 2003-2007: diretrizes, metas e programas. Brasília: MTur, 2003.

BRASIL. Ministério do Turismo. Roteiros do Brasil: diretrizes operacionais. Brasília, MTur, 2004. 
BRASIL. Ministério do Turismo. Plano Nacional 2007- 2010: Uma Viagem de Inclusão. Brasília: MTur, 2007.

BRASIL. Ministério do Turismo. Ações e resultados 2003 - 2010. Brasília: Departamento de Qualificação e Certificação e Produção Associada ao Turismo, 2010.

BRASIL, Ministério do Turismo. Programa Turismo Acessível, 2012. Disponível em: <http://www.turismo.gov.br/turismo/o_ministerio/publicacoes/cadernos_publicacoes/17t urismo_acessivel.html>. Acesso em: 20 out. 2013.

BRASIL. Ministério do Turismo. Plano Nacional 2013-2016: O turismo fazendo muito mais pelo Brasil. Brasília: MTur, 2013a.

BRASIL. Ministério do Turismo. Cartilha Viaja Mais Melhor Idade. $2^{\underline{a}}$ edição. Brasília: MTur, 2013b.

BRASIL. Ministério do Turismo. Manual do Multiplicador - Projeto de Prevenção à Exploração Sexual de Crianças e Adolescentes no Turismo. Universidade de Brasília, Centro de Excelência em Turismo. Brasília, 2013c.

BRASIL. Ministério do Turismo. Programa de Regionalização do Turismo Diretrizes. Brasília: MTur, 2013d.

BRASIL. Ministério do Turismo. Balanço de Gestão. Brasília, MTur, 2014a.

BRASIL. Ministério do Turismo. Cartilha Programa Turismo Acessível. $1^{\underline{a}}$ ed. Brasília: MTur, 2014b.

BRIASSOULIS, H. Crete: Endowed by Nature, Privileg by Geography, Threatened by Tourism? Jounal of Sustainable Tourism 11, no 2-3, 97-115. Journal of Sustainable Tourism, vol. 11, no. 2-3, pp. 97-115.

BRITO, B. R. O Turista e o Viajante: Contributos para a conceptualização do Turismo Alternativo e Responsável. Atas do IV Congresso Português de Sociologia. Coimbra, 2009.

BRUYNE, P. de; JACQUES, H.; SCHOUTHEETE, M. de. - Dinâmica da Pesquisa em Ciências Sociais - Os Polos da Prática Metodológica.

BUTLER, R.W. Sustainable Tourism: a state of art review. In: Tourism Geographies: an international jornal of Tourism space, place and environment. Florence, n.1, v.1, p.725, 1999.

CADENA, N. B. de la. Scheler, os valores, o sentimento e a simpatia. Revista Ética e Filosofia Política - Número XVI - Volume II dezembro de 2013. Disponível em: <www.ufjf.br/eticaefilosofia>. Acesso em: 25 jul. 2014.

COSTA, H.A. Destinos do turismo: percursos para a sustentabilidade. Rio de Janeiro: Editora FGV, 2013. 
CARVAlHo, A. F. de. Políticas Públicas em Turismo no Brasil. In: Sociedade e Cultura, volume 3, no 1 e 2. Goiânia: UFG, jan/dez 2000. p. 97-109

CARVALHO, C. L. de. Políticas Públicas no Turismo Brasileiro: a cidade de São Paulo e a construção de sua identidade turística. Tese apresentada ao Programa de Pós-Graduação na Escola de Comunicações e Artes da Universidade de São Paulo, como requisito para obtenção do título de doutor em Ciências da Comunicação. Orientação: Dra. Beatriz Helena Gelas Lages. São Paulo: USP, 2009.

CIDADE DO CABO, ÁFRICA DO SUL. Cape Town Declaration in Responsible Tourism. Cape Town Conference on Responsible Tourism in Destinations. Cidade do Cabo, 2002.

COOPER, C., et al. Políticas Públicas e turismo In: . Turismo, princípios e práticas. Tradução de Alexandre Salvaterra. $3^{\underline{a}}$ ed. Porto Alegre: Bookman, 2007.

CRUZ, R. de C. A. da. Política de Turismo e Território. $3^{\text {a }}$ ed. São Paulo: Contexto, 2002.

CRUZ, R. de C. A. da. Políticas Públicas de Turismo no Brasil: território usado, território negligenciado. In: Geosul, v. 20, n. 40. Florianópolis: UFSC, jul./dez. 2005. p. 27-43.

DAVIDSON, R. Tourism in Europe. Londres, Inglaterra: Pitman Publishing, 1992.

DENCKER, A. F. M. Métodos e técnicas de Pesquisa em Turismo. São Paulo, SP: Ed. Futura, 1998.

DENCKER, A. de F. M. Pesquisa em Turismo: Planejamento, Métodos e Técnicas. 9aㅡ ed. São Paulo: Editora Futura, 2007.

FERRAZ, J. A. Regime Jurídico do Turismo. $2^{\mathrm{a}}$ ed. atualizada e ampliada. Bauru, SP: EDIPRO, 2001.

FLETCHER, J. Turismo Sustentável. In: COOPER, C.; FLETCHER, J.; FYALL, A., GILBERT, D.; WANHILL, S. Turismo: princípios e práticas. 3ªe ed. Bookmann, 2005.

FRATUCCI, A. C. A Dimensão Espacial nas Políticas Públicas Brasileiras de Turismo: as possibilidades das redes regionais de Turismo. Tese de doutorado apresentada ao Programa de Pós-Graduação em Geografia da Universidade Federal Fluminense. Área de Concentração: Ordenamento Territorial. Niterói, RJ: UFF, 2008.

GÂMBIA. Responsable Turism Policy in The Gambia. 2002. Disponível em: <http://www.accessgambia.com/information/responsible-travel-policy.html>. Acesso em: 25 mai. 2014.

GIL, A. C. Métodos e Técnicas de Pesquisa Social. 2ª ed. São Paulo: Editora Atlas AS, 1989. 
GONSALVES, E. P. Conversas sobre iniciação à pesquisa científica. $3^{a}$ ed. Campinas, SP: Alínea, 2003.

GOODWIN, H. Responsible Tourism and the Market. International Centre for Responsible Tourism. Occasional Paper nํ․ November, 2005.

GOODWIN, H. Taking Responsibility for Tourism. ICRT, 2011.

GOODWIN, H. Ten years of Responsible Tourism: an assessment. In: GOODWIN, H.; FONT, X. (orgs.) Progress in Responsible Tourism Vol 2(1). Woodeaton, Oxford: Ed. Goodfellow Publishers Limited, 2012.

GOODWIN, H., FONT, X.; ALDRIGUI, M. 6th Conference on Responsible Tourism in Destination. Conference Report. Revista Brasileira de Pesquisa em Turismo. São Paulo, v. 6 (3), p. 398-402, set/dez. 2012.

GOODWIN, H. Entrevista concedida à pesquisadora em Brasília, DF em 29 de abril de 2014.

HALL, C. M. Historical antecedentes of sustainable development and ecotourism: new labels on old bottles? In: HALL, C. M.; LEW, A. A. (orgs). Sustainable Tourism: A Geographical Perspective. Pearson, Harlow, UK, p. 13-24.

HALL, C. M. Planejamento turístico: políticas, processos e relacionamentos. São Paulo: Contexto, 2004.

HETZER, Nicholas. Environment, tourism, culture. In: Links, julho de 1965. Reeditado em Ecosphere. 1970.

IGNARRA, L. R. Fundamentos do Turismo. $2^{\underline{a}}$ ed. rev. e ampl. São Paulo: Pioneira Thomson Learning, 2003.

JAFARI, J. Tourism for whom? Old questions still echoing. Annals of Tourism Research 13, 1986. p. 129-137.

JOAQUIM, G. Turismo e Ambiente: complementariedade e responsabilidade. Contribuição para uma abordagem sociológica do fenômeno turístico. Lisboa, Portugal: ISCTE, 1994.

JOAQUIM, G. Da identidade à sustentabilidade ou a emergência do "turismo responsável”. In: Sociologia- Problemas e Práticas. № 23, 1997, p. 71-100.

KANT, I. Fundamentação da metafísica dos costumes e outros escritos. São Paulo, SP: Martin Claret, 2005.

KAVINSKI, H. A apropriação do discurso da sustentabilidade pelas organizações: um estudo multicaso de grandes empresas. 2009. 110f. Dissertação (Mestrado em Organizações e Desenvolvimento) - Coordenação do Programa de Mestrado em Organizações e Desenvolvimento, FAE Centro Universitário, Curitiba, 2009. 
KÖRÖSSY, N. Do "Turismo Predatório" ao "Turismo Sustentável": uma revisão sobre a origem e a consolidação do discurso da sustentabilidade na atividade turística. In: Caderno Virtual de Turismo. Rio de Janeiro: UFRJ, 2008. Vol. 8, n 2.

KRIPPENDORF, J. Sociologia do Turismo. Para uma nova compreensão do lazer e das viagens. Rio de Janeiro: Editora Civilização Brasileira S. A., 1989.

KRIPPENDORF, J. The Holiday Makers: understanding the impact of leisure and travel. Oxford: Butterworth-Heinemann,1987.

LAKATOS, E. M.; MARCONI, M. A. de. Fundamentos de Metodologia Científica. $5^{\mathrm{a}}$ ed. São Paulo: Editora Atlas. 2003.

LESLIE, D. Responsible Tourism. Concepts, Theory and Practice. Oxfordshire, UK: CAB International, 2012.

MARCONDES, D. Textos básicos de ética de Platão a Foucault. Rio de Janeiro: Zahar, 2007.

MENESES; R. D. B.; REIS, A. M. M. G. Responsabilidade em Kant e em Lévinas: entre os conceitos e os fundamentos. In: Curso de Filosofia: Ágora Filosófica. Universidade Católica de Pernambuco. Ano 9 • n. 2 • jul./dez., p. 103-126, 2009.

MINAYO, M. C. (Org.) Pesquisa Social: teoria, método e criatividade. $21^{\mathrm{a}} \mathrm{ed}$. Petrópolis: Vozes, 2002.

MINISTÉRIO DO MEIO AMBIENTE, MINISTÉRIO DO TURISMO, PROGRAMA DAS NAÇÕES UNIDAS PARA O MEIO AMBIENTE. Passaporte Verde: Turismo Sustentável por um planeta vivo. 2009.

MOESCH, M. A Produção do Saber Turístico. 2ª̣ed. São Paulo: Contexto, 2002.

MOESCH, M. M.; GASTAL, S. (orgs.) Um outro turismo é possível. São Paulo: Contexto, 2004.

NASCIMENTO, E. P. Trajetória da sustentabilidade: do ambiental ao social, do social ao econômico. Estudos Avançados 26 (74), 2012, p.51-64.

NEVES, J. L. Pesquisa qualitativa: características, usos e possibilidades. Cadernos de Pesquisas em Administração, FEA-USP. São Paulo, v. 1. n. 3. 2ำ sem, 1996.

NAGABE, F.; MACHADO, A. B. Políticas Públicas e Turismo: uma análise das diretrizes nacionais direcionadas ao setor a partir dos documentos jurídicos (19341977). In: Anais do XXVI Simpósio Nacional de História - ANPUH. São Paulo, julho 2011. Disponível em: <http://www.snh2011.anpuh.org/resources/anais/14/130814758 0_ARQUIVO_Hist_do_Tur_ffinal]_Anpuh_2011.pdf >. Acesso em: 20 nov. 2013. 
OLIVEIRA, Fernando Meloni de. As Políticas de Turismo no Brasil nos Anos Noventa. In: Turismo em Análise. v.19, n.2, agosto 2008. São Paulo: USP, 2008. p. 177-200.

PEREIRA, C. A. S. Políticas Públicas no Setor de Turismo. In: Turismo em Análise, São Paulo, 1999.

POLITO, A.G. Michaelis Moderno Dicionário da Língua Portuguesa, 2004.

PRODANOV, C.C.; FREITAS, E.C. Metodologia do Trabalho Científico: Métodos e Técnicas de Pesquisa e do Trabalho Acadêmico. $2^{\mathrm{a}}$ ed. Novo Hamburgo, RS: Universidade Feevale, 2013.

RICHARDSON, R. J. Pesquisa Social: métodos e técnicas. São Paulo, SP: Ed. Atlas, 1985.

RIOS, Terezinha Azerêdo. Ética e Competência. 8a . ed. São Paulo, SP: Cortez, 1999. (Coleção Questões da nossa época, v.16). p. 21.

ROMERIL, M. Tourism and the environment - accord or discord? Tourism Management, 1989.

ROUSSEAU, J.J. O contrato social. Rio de Janeiro, RJ: Ediouro, 1999.

SEN, A. Desenvolvimento como Liberdade. São Paulo, SP: Companhia das Letras, 2000.

SÁ, C. P. de. A construção do objeto de pesquisa em representações sociais. Rio de Janeiro, RJ: Ed. UERJ, 1998.

SALVATI, S. S. (Org.). Turismo responsável _ Manual de Políticas Públicas. Brasília, DF, WWF Brazil, 2004.

SANTOS FILHO, João dos. O Turismo na Era Vargas e o Departamento de Imprensa e Propaganda - DIP. In: Cultura: revista de cultura e turismo. Ano 2, oㅡ 2, Jul 2008. UESC: 2008. Disponível em: <www.uesc.br/revistas/culturaeturismo/ edica03/artigo6.pdf>. Acesso em: 18 jan. 2014.

SILVEIRA, M. A. T. da. Turismo, Políticas de Ordenamento Territorial e Desenvolvimento. Um foco no Estado do Paraná no Contexto Regional. In: V Encontro Nacional da ANPEGE, Florianópolis, SC: ANPEGE. Contribuições Científicas. Curitiba: Mídia, 2003. v. 1. p. 940-952.

SOLHA, K. T. Evolução do turismo no Brasil. In: MIRIAN R. (Org.). Turismo no percurso do tempo. $2^{\underline{a}}$ ed. São Paulo: Aleph, 2005.

SOUZA, F. M. de. Responsabilidade Socioambiental Em Pequenas Empresas: razões que levam empresas de ecoturismo ao comportamento responsável na 
Chapada dos Veadeiros - GO. Trabalho de Conclusão do Curso de Administração da Universidade de Brasília, Brasília, 2014.

STANFORD Encyclopedia of Philosophy 2014 by The Metaphysics Research Lab, Center for the Study of Language and Information (CSLI), Stanford University. Library of Congress Catalog Data: ISSN 1095-5054. Disponível em: <http://plato.stanford.edu/>. Acesso em: 25 nov. 2013.

TEIXEIRA, Elenaldo Celso. O Papel das Políticas Públicas no Desenvolvimento Local e na Transformação da Realidade. AATR-BA, 2002. Disponível em: <www.fit.br/home/link/texto/politicas_publicas.pdf>. Acesso em: 20 nov. 2013.

TRIGO, L. G. G. Turismo e qualidade: Tendências contemporâneas. 9âed. Campinas, SP: Papirus, 2003. Coleção Turismo.

VALLS, Álvaro L.M. O que é ética? São Paulo: Brasiliense, 1986.

VASQUEZ, A.S. Filosofia da Práxis. Rio de Janeiro, RJ: Paz e Terra, 1977.

WERNECK, V. R. Novos valores ou nova hierarquia de valores? Meta: Avaliação. Rio de Janeiro, v. 2, n. 4, p. 73-86, jan./abr. 2010. Disponível em: <http://metaavaliacao.cesgranrio.org.br/index.php/metaavaliacao/article/viewFile/49/65> Acesso em: 8 jan. 2014. 
APÊNDICE 
Roteiro de entrevista

1- O senhor já ouviu falar de Turismo Responsável?

2- Sabe o que significa Turismo Responsável?

3- Na sua opinião, qual a importância da discussão sobre Turismo Responsável no MTur?

4- Quais são os programas ou as políticas públicas do MTur relacionadas com o Turismo Responsável?

5- Quais são os entraves ou as dificuldades que podem existir para a implantação do Turismo Responsável? 